\title{
PROPOSTAS DE ORIGEM, EVOLUÇÃO E CONTEXTO DA BACIA DA FORMAÇÃO CAMARINHA - TRANSIÇÃO NEOPROTEROZÓICO - EOCAMBRIANO DO ESTADO DO PARANÁ
}

\author{
RENATA DE PAULA XAVIER MORO
}

Orientadora: Prof. Dr. Benjamim Bley de Brito Neves

TESE DE DOUTORAMENTO

COMISSÃO JULGADORA

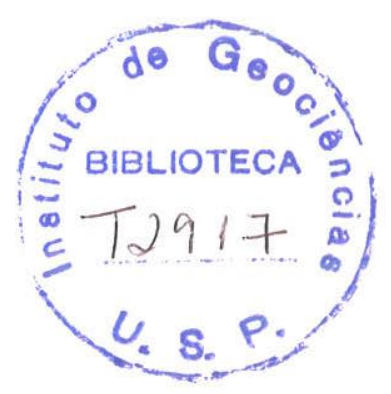

Nome

\section{Assinatura}

Presidente: $\quad$ Prof. Dr. Benjamim Bley de Brito Neves

Examinadores:

Dr. Edison José Milani

Prof. Dr. Fábio Vito Pentagna Paciullo

Prof. Dr. Mario Luis Assine

Prof. Dr. Setembrino Petri

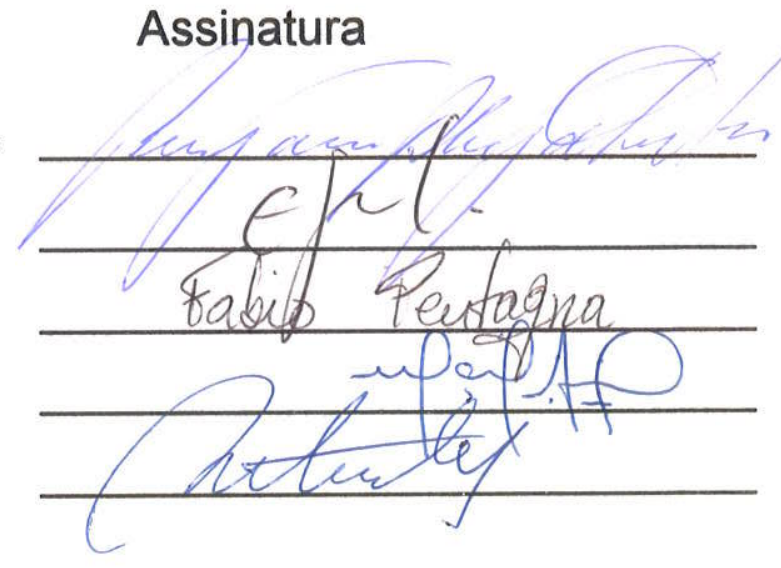

SÃO PAULO

2000 
UNIVERSIDADE DE SÃO PAULO

INSTITUTO DE GEOCIÊNCIAS

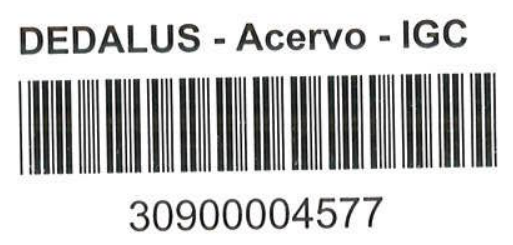

\title{
PROPOSTAS DE ORIGEM, EVOLUÇÃO E CONTEXTO DA BACIA DA FORMAÇÃO CAMARINHA - TRANSIÇÃO NEOPROTEROZÓICO-EOCAMBRIANO DO ESTADO DO PARANÁ
}

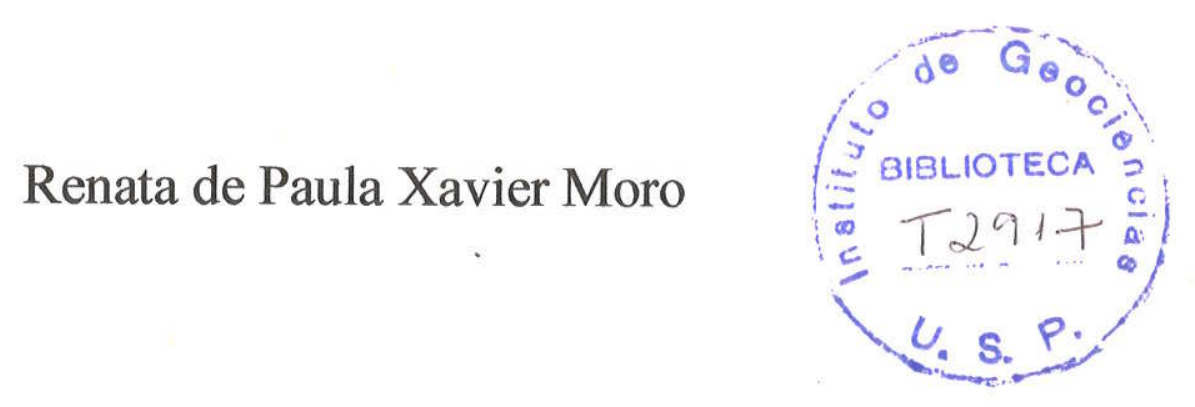

Orientador: Prof. Dr. Benjamim Bley de Brito Neves

\section{TESE DE DOUTORAMENTO}

Programa de Pós-Graduação em Geoquímica e Geotectônica

\author{
SÃO PAULO \\ 2000
}


"Fazer uma tese significa divertir-se, e a tese é como porco: nada se desperdiça"

"Há uma satisfação esportiva em dar caça a um texto que não se encontra, há uma satisfação de charadista em encontrar, após muito refletir, a solução de um problema que parecia insolúvel."

(Umberto Eco: Como se faz uma tese. Ed. Perspectiva, 1977)

A gente pensa uma coisa, acaba escrevendo outra e o leitor entende uma terceira coisa, e, enquanto se passa tudo isso, a coisa propriamente dita começa a desconfiar que não foi propriamente dita

(Mário Quintana - 1906-1994) 


\section{AGRADECIMENTOS}

Ninguém escreve uma tese totalmente sozinho, e quero deixar aqui registrada minha sincera gratidão e meu profundo carinho a todos aqueles que me acompanharam, auxiliaram, apoiaram e suportaram ao longo desta jornada:

- À minha família no Paraná e em São Paulo, em especial a meus pais Orlando e Dora por todo o apoio, a minhas irmãs Maria Lúcia pelas dicas metodológicas, Rosita pelo empréstimo de computador e Mônica pela amizade, e a meu irmão Gil, minha cunhada Simone e minha sobrinha Mariana pela acolhida e apoio em São Paulo;

- Às instituições e empresas que apoiaram este trabalho com infra-estrutura e financiamento, cessão de material, veículo e espaço de trabalho, como: o próprio IG-USP, FAPESP, Depto. de Geologia e Biblioteca do Setor de Tecnologia da UFPR, Dipartimento di Scienze della Terra da Università di Pisa, MINEROPAR, GEOPLOANEJAMENTO, SOLUM e HIDROPAR;

- Aos professores do IG-USP, em especial os doutores Benjamim Bley de Brito Neves, Miguel A. S. Basei, Koji Kawashita, Paulo C. F. Giannini, Setembrino Petri, Antônio R. S. Fragoso César, Osvaldo Siga Jr., Rômulo Machado, Ginaldo A. C. Campanha, Cláudio Riccomini e Daniel Atêncio, pelas valiosas discussões, idéias, críticas e sugestões fornecidas;

- Aos professores externos ao IG-USP, em especial os doutores Paulo César Soares (UFPR), Alberto Pio Fiori (UFPR), Elvo Fassbinder (UFPR), José Manoel dos Reis Neto (UFPR), Eleonora Vasconcellos (UFPR), Francisco José Fonseca Ferreira (UFPR), Sidnei Pires Rostirolla (UFPR), Maria José M. de Mesquita (UFPR), Mário L. Assine (IGCE-UNESP), Renato Andreis (UFRJ) e Graziano Plesi e equipe (Università di Pisa), pelas discussões e apoio proporcionados com tanta boa vontade;

- Aos funcionários de secretarias, laboratórios e bibliotecas do IG-USP e da UFPR, pela disponibilidade e empenho;

- Aos colegas do IG-USP, como Délzio de Lima Machado Jr., Antônio Luís "Candeias" Teixeira, Gélson "Sapo" Fambrini, Alexis Nummer, Afonso Nogueira, Jefferson Picanço, Gilberto Kaulfuss, Hélcio dos Prazeres Filho, Maria da Glória "Glorinha" M. Garcia, Leandro M. Donatti, Raquel Florêncio, Annabel "Coca" Pérez Aguilar e demais amigos que fiz ao longo desses anos, pelas discussões, trocas de idéias, auxílio, apoio e amizade;

- Aos colegas e amigos geólogos e não-geólogos externos ao IG-USP, especialmente Elaine A. Bonacim, Leila C. Perdoncini, Andréa C. Hauch, José R. de Góis, Dr. Augusto J. Pedreira, 
Antônio "Toni" Paranhos Filho, Jocelyn Souza, Fernando E. Fridlund, Marcos Vinícius Silva e Gilson Bonfiglio, pelo imenso apoio e ajuda;

- E a todos aqueles que possam (injustamente) não ter sido citados... 


\section{SUMÁRIO}

RESUMO

\section{xviii}

ABSTRACT

xix

1. INTRODUÇÃO

1.1. Objetivos e justificativas

1.2. Localização e vias de acesso

1.3. Materiais, métodos e terminologia empregados

2. TRABALHOS ANTERIORES E GEOLOGIA REGIONAL 13

2.1. Bacia da Formação Camarinha $\quad 13$

2.2. Contexto Geológico Regional 16

2.2.1. Complexo Atuba 18

2.2.2. Núcleo Betara $\quad 21$

2.2.3. Formação Água Clara $\quad 21$

2.2.4. Formações Votuverava e Capiru 22

2.2.5. Seqüência Antinha 23

2.2.6. Rochas graníticas $\quad 24$

2.2.7. Quadro estrutural regional 26

2.3. Bacias e ocorrências da transição Neoproterozóico-Eocambriano do Sul e

Sudeste do Brasil

2.3.1. Eleutério e Pouso Alegre

2.3.2. Pico de Itapeva e outras ocorrências menores no Estado de São Paulo

2.3.4. Ervalzinho

2.3.5. Guaratubinha

2.3.6. Campo Alegre-Corupá $\quad 33$

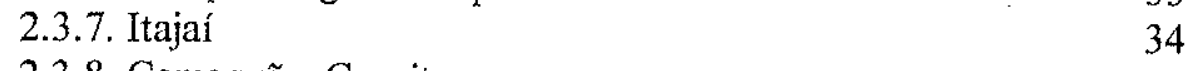

$\begin{array}{ll}\text { 2.3.8. Camaquã e Guaritas } & 35\end{array}$

3. LITOESTRATIGRAFIA E PETROGRAFIA

3.1. Características gerais $\quad 39$

3.2. Aspectos de campo $\quad 52$

3.2.1. Unidade Conglomerática $1 \quad 52$

3.2.2. Unidade Areno-Lamítica $1 \quad 53$

3.2.3. Unidade Conglomerática $2 \quad 58$

3.2.4. Unidade Areno-Lamítica 2 60

3.3. Petrografia 65

$\begin{array}{ll}\text { 3.3.1. Observações } & 65\end{array}$

3.3.2. Unidade Areno-Lamítica 1 66

$\begin{array}{ll}\text { 3.3.3. Unidade Conglomerática 2 } & 70\end{array}$

3.3.4. Unidade Areno-Lamítica 2

$\begin{array}{lr}\text { 3.4. Difratometria de Raios X } & 73\end{array}$ 
4. ANÁLISE ESTRATIGRÁFICA E SEDIMENTOLÓGICA

4.1. Análise de proveniência $\quad 78$

4.2. Análise de fácies e ambientes $\quad 85$

5. FEIÇÕES ESTRUTURAIS 96

5.1. Características gerais $\quad 96$

5.2. Área Norte $\quad 96$

$\begin{array}{ll}\text { 5.2.1. Estruturas dúcteis } & 96 \\ \text { 5.3. Área Sul } & 100\end{array}$

5.3.1. Estruturas dúcteis $\quad 100$

$\begin{array}{ll}\text { 5.3.2. Estruturas rúpteis } & 102\end{array}$

5.3.3. Análise da deformação de clastos 107

6. IDADE 116

6.1. Feições da geocronologia Rb-Sr em Rocha Total 116

$\begin{array}{ll}\text { 7. DISCUSSÃO DOS RESULTADOS } & 122\end{array}$

\begin{tabular}{ll} 
7.1. Atualização do Mapa Geológico & 122 \\
\hline
\end{tabular}

$\begin{array}{ll}\text { 7.2. Preenchimento sedimentar } & 123\end{array}$

$\begin{array}{ll}\text { 7.3. Tectônica deformadora } & 125\end{array}$

$\begin{array}{ll}\text { 7.4. Idades } & 127 \\ 7.5 . \text { Modelos classificatórios e discussão } & 127\end{array}$

$\begin{array}{ll}\text { 7.5. Modelos classificatórios e discussão } & 127\end{array}$

$\begin{array}{ll}\text { 7.5.1. Modelos tardi-orogênicos } & 128\end{array}$

$\begin{array}{ll}\text { 7.5.2. Modelos pós-orogênicos } & 132\end{array}$

$\begin{array}{ll}\text { 7.6. Correlações } & 140\end{array}$

8. CONCLUSÕES 143

$\begin{array}{ll}\text { 8.1. Principais conclusões } & 143\end{array}$

8.2. Etapas posteriores de pesquisa sugeridas 144

9. REFERÊNCIAS BIBLIOGRÁFICAS 146

\section{LISTA DE FIGURAS}

Fig.1.1: Localização e situação das áreas aflorantes da Formação Camarinha no Estado do Paraná

Fig.1.2: Vias de acesso às áreas aflorantes da Formação Camarinha no Estado do Paraná

4

Fig.1.3: Classificação modal de arenitos segundo Dott (1964) (A) e Pettijohn et al. (1987) (B) .

Fig.2.1: Contexto geológico regional da Formação Camarinha

Fig.2.2: Unidades do embasamento da Formação Camarinha 
Fig.2.3: Bacias e ocorrências de sedimentos da transição NeoproterozóicoEocambriano no Sul e Sudeste do Brasil

Fig.3.1: Unidades da Formação Camarinha

Fig.3.2: Bloco-diagrama esquemático das unidades da Formação Camarinha

Fig.3.3: Seções esquemáticas ideais das unidades constituintes da Formação Calrinha nas áreas Norte e Sul

Fig.3.4a: Seção colunar das unidades Conglomerática 1 e Areno-Lamítica 1 da Formação Camarinha, representando a transição entre ambas e a porção basal da Unidade Areno-Lamítica 1

Fig.3.4b: Seção colunar da porção basal da Unidade Areno-Lamítica 1 da Formação Camarinha (continuação da seção anterior)

Fig.3.5: Seções colunares parciais da Unidade Areno-Lamítica 1 da Formação Camarinha, representando sua porção basal a intermediária 46

Fig.3.6a: Seção colunar da Unidade Areno-Lamítica 1 da Formação Camarinha, representando parte da sua porção intermediária

Fig.3.6b: Seção colunar da Unidade Areno-Lamítica 1 da Formação Camarinha, representando parte da sua porção intermediária (continuação da seção anterior)

Fig.3.6c: Seção colunar da Unidade Areno-Lamítica 1 da Formação Camarinha, representando parte da sua porção intermediária próxima ao topo (continuação da seção anterior)

Fig.3.6d: Seção colunar da Unidade Areno-Lamítica 1 da Formação Camarinha, representando parte da sua porção superior e o início da transição para a Unidade Conglomerática 2 (continuação da seção anterior)

Fig.3.6e: Seção colunar das unidades Areno-Lamítica 1 e Conglomerática 2 da Formação Camarinha, representando a transição entre ambas e a porção basal da Unidade Conglomerática 2 (continuação da seção anterior)

Fig.3.7: Diagramas QFL de Dott (1964) e Pettijohn et al. (1987) para classificação modal de arenitos

Fig.3.8: Difratogramas da fração fina de lamitos da Unidade Areno-Lamítica 177

Fig.4.1: Distribuição dos sentidos de paleocorrentes corrigidos na Formação Camarinha 
Fig.4.2: Diagrama QmFLt de Dickinson et al. (1983) para ambientes geotectônicos de proveniência de arenitos

Fig.4.3: Sucessão de litofácies identificadas na Formação Camarinha de acordo com o empilhamento geral de suas unidades constituintes (Área Sul e Área Norte)

Fig.4.4: Leque do tipo fandelta retrogradante, com suas regiões proximais, medianas e distais e possíveis equivalentes na base da Formação Camarinha, correspondentes às unidades Conglomerática 1 e Areno-Lamítica 194

Fig.4.5: Leque do tipo fandelta progradante, com suas regiões proximais, medianas e distais e possiveis equivalentes no topo da Formação Camarinha, correspondentes às unidades Conglomerática 2 e Areno-Lamítica 295

Fig.5.1: Principais lineamentos e estruturas regionais da Formação Camarinha e áreas adjacentes (Imagem Landsat, Banda 5 com ALC - Aumento Linear de Contraste)

97

Fig.5.2: Principais lineamentos e estruturas regionais da Formação Camarinha e áreas adjacentes (Composição colorida de Imagens Landsat, Bandas 3, 4 e 5) 98

Fig.5.3: Estereograma de acamamentos (So) da Formação Camarinha na Área Norte, mostrando dobramento aberto com plano axial de direção $\mathrm{N} 56^{\circ} \mathrm{E}$, caimento de eixo para $\mathrm{S} 56^{\circ} \mathrm{W}$ e camadas verticalizadas devido à proximidade com zonas de falhamentos transcorrentes (Falha de Morro Agudo)

99

Fig.5.4: Estereograma de acamamentos (So) da Formação Camarinha na Área Sul (bloco ao sul da Falha da Lancinha), mostrando dobramento com plano axial de direção $\mathrm{N} 50-60^{\circ} \mathrm{E}$, caimento de eixo principal para $\mathrm{S} 60^{\circ} \mathrm{W}$ e secundário para $\mathrm{N} 36^{\circ} \mathrm{E}$, e camadas verticalizadas devido à proximidade com zonas de falhamentos transcorrentes (falhas da Lancinha e do Cal)

Fig.5.5: Estereograma de acamamentos (So) da Formação Camarinha na Área Sul (bloco ao norte da Falha da Lancinha), mostrando estrutura cônica de direção $\mathrm{N} 74^{\circ} \mathrm{W}$ a $\mathrm{N} 88^{\circ} \mathrm{E}$, sem relação com os dobramentos escalonados

Fig.5.6: Atitudes de acamamentos da Formação Camarinha em relação aos dobramentos escalonados

Fig.5.7: Estereograma de medidas de fraturas da Formação Camarinha (Área Sul), mostrando estruturas rúpteis associadas à zona de cisalhamento transcorrente da Falha da Lancinha, como fraturas associadas à zona de cisalhamento principal 
$\left(\mathrm{N} 55^{\circ} \mathrm{E} /\right.$ subvert e $\mathrm{N} 64^{\circ} \mathrm{E} / \mathrm{subvert}$ a $\left.65^{\circ} \mathrm{NW}\right)$, falhas sintéticas $\left(\mathrm{N} 76^{\circ} \mathrm{W} /\right.$ subvert e $\mathrm{N} 86^{\circ} \mathrm{E} /$ subvert) e antitéticas ( $\left.\mathrm{N} 35^{\circ} \mathrm{W} / \mathrm{subvert}\right)$, fraturas $\mathrm{T}\left(\mathrm{N} 55^{\circ} \mathrm{W} /\right.$ subvert) e $\mathrm{X}$ (N08 ${ }^{\circ} \mathrm{E} /$ subvert) e clivagem de fratura $\left(\mathrm{N} 34^{\circ} \mathrm{E} /\right.$ subvert) relacionada a dobras escalonadas

Fig.5.8: Estereograma de medidas de foliação cataclástica da Formação Camarinha (Área Sul), mostrando estruturas associadas à zona de cisalhamento transcorrente da Falha da Lancinha, como as desenvolvidas ao longo da zona de cisalhamento principal $\left(\mathrm{N} 56^{\circ} \mathrm{E} / \mathrm{subvert}\right)$ e das falhas sintéticas $\left(\mathrm{N} 86^{\circ} \mathrm{E} /\right.$ subvert a $\mathrm{N} 76^{\circ} \mathrm{W} /$ subvert), e a foliação plano-axial relacionada a dobras escalonadas $\left(\mathrm{N} 26^{\circ} \mathrm{E}\right.$ a $\mathrm{N} 40^{\circ} \mathrm{E} /$ subvert) 108

Fig.5. 9a: Estereogramas de clastos estirados em brechas da Unidade Conglomerática 2 da Formação Camarinha, mostrando direção principal de estiramento do eixo $\mathrm{X}$ (Lx) com caimentos sub-horizontais, nos valores de $\mathrm{N} 40^{\circ} \mathrm{E} / 8^{\circ}$ (A) e $\mathrm{N} 60^{\circ} \mathrm{E} / 10^{\circ}$ (B), próximos aos valores de eixos de dobramentos escalonados apresentados na Fig.5.4 110

Fig.5.9b: Estereogramas de clastos estirados em brechas da Unidade Conglomerática 2 da Formação Camarinha (cont.), mostrando direção principal de estiramento do eixo $\mathrm{X}(\mathrm{Lx})$ com caimentos sub-horizontais, nos valores de $\mathrm{N} 38^{\circ} \mathrm{E} / 20^{\circ}(\mathrm{C})$ e $\mathrm{N} 35^{\circ} \mathrm{E} / 10^{\circ}$ (D), próximos aos valores de eixos de dobramentos escalonados apresentados na Fig.5.4

Fig.5.10: Pontos de coleta de medidas de eixos $\mathrm{X}$ em clastos estirados da Unidade Conglomerática 2 da Formação Camarinha e orientação dos mesmos em relação à Falha da Lancinha

Fig.5.11: Diagramas de isocurvas de $R f$ em clastos da Unidade Conglomerática 2 da Formação Camarinha e elipsóides de deformação respectivos

Fig.6.1: Isócrona tipo Williamson das amostras de fração fina de lamitos do ponto $\mathrm{S} 61$ (Unidade Areno-Lamítica 1) da Formação Camarinha, para idade Rb-Sr de 432.8 $+6.3 \mathrm{Ma}$ e MSWD $=23.50$

Fig.6.2: Isócrona tipo Williamson das amostras de fração fina de lamitos dos pontos S61, S67 e S123 (Unidade Areno-Lamítica 1) da Formação Camarinha, para idade $\mathrm{Rb}-\mathrm{Sr}$ de $437.7+2.5 \mathrm{Ma}$ e MSWD $=18.17$ 
Fig.7.1: Possíveis modelos para a origem da Bacia da Formação Camarinha em ambiente tardi-orogênico: bacia de foreland retro-arco

Fig.7.2: Possíveis modelos para a origem da Bacia da Formação Camarinha em ambiente tardi-orogênico: bacia de piggyback

Fig.7.3: Possíveis modelos para a origem da Bacia da Formação Camarinha em ambiente pós-orogênico: bacia de strike-slip transtrativa

Fig.7.4: Possiveis modelos para a origem da Bacia da Formação Camarinha em ambiente pós-orogênico: bacia de strike-slip transpressiva

Fig.7.5: Possíveis modelos para a origem da Bacia da Formação Camarinha em ambiente pós-orogênico: graben extensional (intermontano)

Fig.7.6: Deformação e preservação da Bacia da Formação Camarinha pela tectônica de cisalhamento transcorrente relacionada à Falha da Lancinha

\section{LISTA DE QUADROS E TABELAS}

Quadro 1.1: Esquema de codificação e descrição de litofácies fluviais

Quadro 1.2: Processos e mudanças diagenéticas que ocorrem em rochas terrígenas durante o soterramento

Quadro 2.1: Síntese das unidades constituintes do embasamento da Formação Camarinha

Quadro 4.1: Fácies identificadas nas unidades da Formação Camarinha e suas interpretações

Quadro 6.1: Idades de formação ou alterações de rochas sedimentares e vulcânicas de parte das bacias eopaleozóicas do Sul e Sudeste do Brasil, baseadas em datações radiométricas diversas e análise de conteúdo fossilifero 
Tab.4.1: Sentidos de paleocorrentes corrigidos nas diferentes unidades da Formação Camarinha

Tab.6.1: Dados resultantes da diluição isotópica efetuada para datação geocronológica Rb-Sr em lamitos da Unidade Areno-Lamítica 1 da Formação Camarinha 117

\section{LISTA DE FOTOGRAFIAS}

\section{PRANCHA 1}

FOTO 3.1: Contato entre filitos da Formação Capiru e conglomerados da Unidade Conglomerática 1 da Formação Camarinha

FOTO 3.2: Arenito médio a fino, maciço, da Unidade Areno-Lamítica 1 da Formação Camarinha

FOTO 3.3: Arenitos gradacionais da Unidade Areno-Lamítica 1 da Formação Camarinha, mostrando base conglomerática com intraclastos síltico-argilosos passando a arenitos com estratificação paralela e cruzada climbing 55

FOTO 3.4: Intraclastos sílticomargilosos em arenitos de base grossa a conglomerática da Unidade Areno-Lamítica 1 da Formação Camarinha 55

FOTO 3.5: Marcas onduladas simétricas de interferência em arenitos médios a finos da Unidade Areno-Lamítica 1 da Formação Camarinha

FOTO 3.6: Marcas onduladas assimétricas de interferência em arenitos médios a finos da Unidade Areno-Lamítica 1 da Formação Camarinha

\section{PRANCHA 2}

FOTO 3.7: Laminações paralela, wavy e flaser em ritmitos da Unidade Areno-Lamítica 1 da Formação Camarinha

FOTO 3.8: Laminações paralela, ondulada, wavy, lenticular e cruzada tangencial em ritmitos da Unidade Areno-Lamítica 1 da Formação Camarinha 56

FOTO 3.9: Laminações cruzadas climbing em lamitos da Unidade Areno-Lamítica 1 da Formação Camarinha 
FOTO 3.10: Laminações cruzadas climbing e lenticulares em ritmitos da Unidade Areno-Lamítica 1 da Formação Camarinha

\section{PRANCHA 3}

FOTO 3.11:Laminações cruzadas climbing e lenticulares em ritmitos da Unidade Areno-Lamítica 1 da Formação Camarinha

FOTO 3.12: Laminações onduladas, wavy e flaser em ritmitos da Unidade ArenoLamítica 1 da Formação Camarinha

FOTO 3.13: Laminações paralela, ondulada assimétrica, cruzada tangencial e flaser em ritmitos da Unidade Areno-Lamítica I da Formação Camarinha

FOTO 3.14: Laminações convolutas em ritmitos da Unidade Areno-Lamítica 1 da Formação Camarinha

FOTO 3.15: Laminações lenticulares e estruturas de escape de água em ritmitos da Unidade Areno-Lamítica 1 da Formação Camarinha

FOTO 3.16: Estruturas de escape de água em ritmitos da Unidade Areno-Lamítica 1 da Formação Camarinha

57

\section{PRANCHA 4}

FOTO 3.17: Laminação cruzada tangencial em arenitos grossos da transição Unidade Areno-Lamítica 1 - Unidade Conglomerática 2 da Formação Camarinha 59

FOTO 3.18: Estratificações cruzadas tangenciais em arenitos grossos a conglomeráticos da transição Unidade Areno-Lamítica 1 - Unidade Conglomerática 2 da Formação Camarinha

FOTO 3.19: Arenitos grossos a conglomeráticos da transição Unidade Areno-Lamítica 1 - Unidade Conglomerática 2 da Formação Camarinha, com estratificação cruzada tangencial e superfície erosiva no topo do nível arenoso 59

FOTO 3.20: Nível lamítico intercalado a arenitos grossos a conglomeráticos da transição Unidade Areno-Lamítica 1 - Unidade Conglomerática 2 da Formação Camarinha, com intraclastos de argila no nível arenoso superior

59

\section{PRANCHA 5}

FOTO 3.21A,B: Brecha intraformacional polimítica maciça da Unidade Conglomerática 2 da Formação Camarinha 
FOTO 3.22A,B: Brecha intraformacional polimítica estratificada da Unidade Conglomerática 2 da Formação Camarinha

FOTO 3.23: Brecha intraformacional polimítica maciça a incipientemente estratificada da Unidade Conglomerática 2 da Formação Camarinha

\section{PRANCHA 6}

FOTO 3.24A,B,C: Brecha intraformacional polimítica estratificada da Unidade Conglomerática 2 da Formação Camarinha; seta indica clastos de arenito e lamito provenientes da Unidade Areno-Lamítica 1

FOTO 3.25A,B,C: Clastos de rochas graníticas, cálcio-silicáticas e metavulcânicas em conglomerados da Unidade Conglomerática 2 da Formação Camarinha

62

\section{PRANCHA 7}

FOTO 3.26A,B: Clastos de rochas graníticas, cálcio-silicáticas e metavulcânicas em conglomerados da Unidade Conglomerática 2 da Formação Camarinha 64

FOTO 3.27: Marcas onduladas em arenitos médios da Unidade Areno-Lamítica 2 da Formação Camarinha

FOTO 3.28: Laminações ondulada assimétrica, wavy, flaser e cruzada tangencial em ritmitos da Unidade Areno-Lamítica 2 da Formação Camarinha

FOTO 3.29: Laminações ondulada assimétrica, wavy, lenticular e pseudonódulos de areia em ritmitos da Unidade Areno-Lamítica 2 da Formação Camarinha 64

\section{PRANCHA 8}

FOTO 3.30: Arenito feldspático da Unidade Areno-Lamítica 1 da Formação Camarinha

FOTO 3.31: Arenito feldspático da Unidade Areno-Lamítica 1 da Formação Camarinha 68

FOTO 3.32: Arenito feldspático a lítico da Unidade Areno-Lamítica 1 da Formação Camarinha

\section{PRANCHA 9}

FOTO 3.33: Fragmentos de xisto e chert em arenito feldspático a lítico da Unidade Areno-Lamítica 1 da Formação Camarinha 
FOTO 3.34: Arenito feldspático da Unidade Areno-Lamítica 1 da Formação Camarinha

FOTO 3.35: Tingimento de arenito feldspático da Unidade Areno-Lamítica 1 da Formação Camarinha por óxidos e hidróxidos de ferro disseminados

FOTO 3.36: Alteração sericítica disseminada em arenito feldspático da Unidade ArenoLamítica 1 da Formação Camarinha

FOTO 3.37: Brecha polimítica intraformacional da Unidade Conglomerática 2 da Formação Camarinha

\section{PRANCHA 10}

FOTO 3.38: Brecha polimítica intraformacional da Unidade Conglomerática 2 da Formação Camarinha

FOTO 3.39: Brecha polimítica intraformacional da Unidade Conglomerática 2 da Formação Camarinha

FOTO 3.40: Brecha polimítica intraformacional da Unidade Conglomerática 2 da Formação Camarinha

FOTO 3.41: Brecha polimítica intraformacional da Unidade Conglomerática 2 da Formação Camarinha

\section{PRANCHA 11}

FOTO 3.42A,B: Fraturamentos e preenchimento de fraturas com micas finas, quartzo e carbonatos de origem hidrotermal em arenitos grossos a conglomeráticos da transição Unidade Areno-Lamítica 1 - Unidade Conglomerática 2 da Formação Camarinha;

FOTO 3.43A,B: Fraturamentos e preenchimento de fraturas com micas finas, quartzo e carbonatos de origem hidrotermal em arenitos grossos a conglomeráticos da Unidade Conglomerática 2 da Formação Camarinha

FOTO 3.44: Arenitos feldspáticos da Unidade Conglomerática 2 da Formação Camarinha

\section{PRANCHA 12}

FOTO 3.45: Micas detríticas em arenitos feldspáticos da Unidade Conglomerática 2 da Formação Camarinha 
FOTO 3.46: Fragmento de granito em arenito feldspático da Unidade Areno-Lamítica 2 da Formação Camarinha

FOTO 3.47A,B: Fraturamentos e preenchimento de fraturas com micas finas, quartzo e carbonatos de origem hidrotermal em arenitos médios a grossos da Unidade Areno-Lamítica 2 da Formação Camarinha

\section{PRANCHA 13}

FOTO 4.1: Fácies Gmu representativa de fluxos de detritos na Unidade Conglomerática 1 da Formação Camarinha

FOTO 4.2: Fácies Sh e Sp representativas de correntes de turbidez de alta a baixa densidade em arenitos gradacionais da Unidade Areno-Lamítica 1 da Formação Camarinha, mostrando base conglomerática com intraclastos síltico-argilosos passando a arenitos com estratificação paralela e cruzada climbing)

FOTO 4.3: Fácies Sr representativa de retrabalhamento por ondas no topo de depósitos de correntes de turbidez de alta a baixa densidade na Unidade Areno-Lamítica 1 da Formação Camarinha

FOTO 4.4: Fácies de ritmitos síltico-argilosos com laminações paralelas, onduladas e cruzadas diversas, representando depósitos de barra de desembocadura distais em zonas de frente deltaica na Unidade Areno-Lamítica 1 da Formação Camarinha

FOTOS 4.5 e 4.6: Fácies de lamitos e ritmitos síltico-argilosos com laminações onduladas e cruzadas diversas, representando depósitos de barra de desembocadura distais em zonas de frente deltaica na Unidade Areno-Lamítica 1 da Formação Camarinha

\section{PRANCHA 14}

FOTO 4.7: Fácies Gmu representativa de fluxos de detritos na transição Unidade Areno-Lamítica 1 - Unidade Conglomerática 2 da Formação Camarinha 90

FOTO 4.8: Fácies St e Sp representativas de fluxos desconfinados característicos de sheet-floods na transição Unidade Areno-Lamítica 1 - Unidade Conglomerática 2 da Formação Camarinha

FOTO 4.9: Fácies Fl representativa de decantação final de enchentes em depressões localizadas sobre depósitos de sheet-floods na transição Unidade Areno-Lamítica 
1 - Unidade Conglomerática 2 da Formação Camarinha, com intraclastos no nível superior representante do fluxo seguinte

FOTO 4.10: Fácies Gh representativa de preenchimento de canais com base erosiva em depósitos de sheet-floods na transição Unidade Areno-Lamítica 1- Unidade Conglomerática 2 da Formação Camarinha

FOTO 4.11: Fácies Gm representativa de fluxos de detritos na Unidade Conglomerática 2 da Formação Camarinha

FOTO 4.12: Fácies Gm representativa de fluxos de detritos na Unidade Conglomerática 2 da Formação Camarinha 90

\section{PRANCHA 15}

FOTO 4.13: Fácies Sh representativa de possíveis preenchimentos de canais sobre depósitos de fluxos de detritos na Unidade Conglomerática 2 da Formação Camarinha

FOTO 4.14: Fácies Gmu representativa de fluxos de detritos subaquosos na transição Unidade Conglomerática 2 - Unidade Areno-Lamítica 2 da Formação Camarinha

FOTO 4.15: Fácies Sr representativa de retrabalhamento por ondas bidirecionais (marés?) em depósitos arenosos de barra de desembocadura em zonas de frente deltaica na Unidade Areno-Lamítica 2 da Formação Camarinha

FOTO 4.16: Fácies de lamitos e ritmitos síltico-argilosos com laminações onduladas e cruzadas diversas, representando depósitos de barra de desembocadura distais em zonas de frente deltaica na Unidade Areno-Lamítica 1 da Formação Camarinha

\section{PRANCHA 16}

FOTO 5.1: Ressaltos e estria de atrito $\mathrm{N} 55^{\circ} \mathrm{E} / 4^{\circ}$ em plano $\mathrm{N} 65^{\circ} \mathrm{E} / 90^{\circ}$ em arenitos médios da Unidade Areno-Lamítica 2 da Formação Camarinha evidenciando movimento Lateral Direito; seta indica sentido de movimento do bloco fotografado

FOTO 5.2: Ressaltos e estria de atrito $\mathrm{N} 50^{\circ} \mathrm{W} / 55^{\circ} \mathrm{em}$ plano $\mathrm{N} 60^{\circ} \mathrm{E} / 60 \mathrm{NW} \mathrm{W}^{\circ}$ em arenitos médios da Unidade Areno-Lamítica 2 da Formação Camarinha evidenciando movimento Normal 
xvii

FOTO 5.3A,B: Falhas sintéticas $\mathrm{N} 75^{\circ} \mathrm{W} / 90^{\circ}$ em arenitos médios a grossos e conglomeráticos da transição entre as unidades Areno-Lamítica $1 \mathrm{e}$ Conglomerática 2 da Formação Camarinha

FOTO 5.4: Fraturas $\mathrm{T} \mathrm{N} 60^{\circ} \mathrm{W} / 40^{\circ} \mathrm{SW}$ com estria de atrito $\mathrm{S} 85^{\circ} \mathrm{W} / 30^{\circ}$ em arenitos médios a grossos da Unidade Areno-Lamítica 1 da Formação Camarinha 106

FOTO 5.5: Visão em planta de clivagem de fratura $\mathrm{N} 34^{\circ} \mathrm{E} / 90^{\circ}$ em arenitos finos a sílticos da Unidade Areno-Lamítica 1 da Formação Camarinha

106

\section{PRANCHA 17}

FOTO 5.6A,B: Clastos estirados em brechas da Unidade Conglomerática 2 da Formação Camarinha

FOTO 5.7A,B: Clastos estirados em brechas da Unidade Conglomerática 2 da Formação Camarinha

\section{LISTA DE ANEXOS}

Anexo I: Mapa Geológico da Bacia da Formação Camarinha e unidades adjacentes - PR Anexo II: Mapa de localização de afloramentos da Bacia da Formação Camarinha - PR (Área Sul)

Anexo III: Mapa de localização de afloramentos da Bacia da Formação Camarinha PR (Área Norte) 


\section{RESUMO}

A bacia da Formação Camarinha, no centro-leste do Estado do Paraná, representa uma unidade da transição Neoproterozóico-Eocambriano na região. Assenta-se discordantemente sobre os metassedimentos proterozóicos do Cinturão Ribeira, constituídos pelas formações Água Clara, Votuverava e Capiru e próximos ao Complexo Atuba, Núcleo Betara e Complexo Granítico Três Córregos, e é recoberta também discordantemente, a oeste, pelos sedimentos basais devonianos da Bacia do Paraná.

A Formação Camarinha consiste em conglomerados, brechas, arenitos, siltitos, lamitos e ritmitos imaturos, medianamente a mal selecionados, distribuídos em quatro unidades intercaladas e com contatos transicionais entre si, das quais duas apresentam natureza mais conglomerática, e duas natureza mais síltico-arenosa. Estas unidades foram depositadas por processos como fluxos gravitacionais subaéreos a subaquosos, correntes de turbidez, sheet-floods e processos atuantes em frentes deltaicas, comuns em leques progradantes e retrogradantes de ambientes costeiros (fandeltas). As áreas-fontes dos sedimentos são representadas pelas formações Água Clara, Votuverava e Capiru e pelos complexos Atuba e Três Córregos.

Posteriormente, a bacia foi deformada pela atuação da Zona de Cisalhamento Transcorrente da Lancinha, com deslocamento lateral direito que gerou diversas estruturas rúpteis a rúpteisdúcteis previstas no Modelo de Riedel. Reativações deste sistema proporcionaram intensa alteração hidrotermal, refletida em isócronas $\mathrm{Rb}$-Sr obtidas.

A Formação Camarinha encontra-se atualmente preservada em duas faixas dobradas na forma de sinclinais relacionados à Falha da Lancinha, constituindo remanescentes da bacia original. Os limites originais da bacia não se encontram preservados, tendo a mesma sido formada em ambiente tardi a pós-orogênico com relação ao Ciclo Brasiliano, bem como outras bacias similares do sul e sudeste do Brasil. 


\section{ABSTRACT}

Camarinha Formation (central-eastern part of the State of Paraná, southern Brazil) is a transitional unit between Neoproterozoic and Cambrian in that region. It lies unconformably on proterozoic sediments of the Ribeira Belt (Água Clara, Votuverava and Capiru formations), near the Atuba, Betara and Três Córregos complexes. On its western part, it is also unconformably covered by the devonian basal sediments of the Paraná Basin.

Camarinha Formation consits of medium-to-poorly sorted, immature rocks, such as conglomerates, breccias, sandstones, siltstones, mudstones and rythmites, grouped into four altenating units with transitional contacts. Two of these units have a conglomeratic nature, and two have a sandy and muddy nature. These units were deposited by processes such as subaerial to subaqueous gravity-flows, turbidity currents, sheet-floods and other processes that occur in delta fronts. These processes are common in prograding and retrograding fans at coastal environments (fandeltas). The sediments source areas are represented by the Água Clara, Votuverava and Capiru formations, and Atuba and Três Córregos complexes.

The basin was later deformed by the Lancinha Shear Zone, whose right-lateral movement generated several ruptile to ruptile-ductile structures of the Riedel Model. Later reactivations of the shear zone caused intense hydrothermal alteration, whose age was measured with $\mathrm{Rb}-\mathrm{Sr}$ data.

Camarinha Formation is now preserved as remains of the original basin, in two folded zones forming synclinals related to the Lancinha Shear Zone. The basin original borders are not preserved. The basin was formed in a late-to-post orogenic environment related to the Brasiliano Cycle, just like other similar basins in southern and southeastern Brazil. 


\section{INTRODUCÃO}

\subsection{OBJETIVOS E JUSTIFICATIVAS}

Para um estudo abrangente e integrado dos terrenos pré-cambrianos e eocambrianos do Estado do Paraná, visando uma compreensão global da evolução dos mesmos, tornam-se importantes estudos mais detalhados sobre as bacias desenvolvidas na transição NeoproterozóicoEocambriano da região. Isto deve-se ao fato de que estas bacias, anteriormente ditas "molássicas", fornecem importantes informações sobre o estágio evolutivo da tectônica regional e das bacias associadas, das condições climáticas e ambientais vigentes à época, etc.

No Estado do Paraná, a bacia da Formação Camarinha vem a ser uma das menos estudadas dentre as bacias da transição Neoproterozóico-Eocambriano do Sul e Sudeste do Brasil. O estudo dessa formação pode contribuir para o estabelecimento do ciclo completo da evolução do cinturão orogênico formado durante o Ciclo Brasiliano. Para atingir esse objetivo, pretende-se, neste trabalho:

- Atualizar o mapeamento geológico já existente produzindo-se um novo mapa em escala 1:50.000, por meio de técnicas de fotointerpretação e trabalhos de campo;

- Analisar o preenchimento sedimentar da mesma, por meio do estudo do empilhamento estratigráfico, características e proveniência dos sedimentos constituintes, e determinação dos ambientes e fácies sedimentares;

- Efetuar análise da tectônica deformadora da bacia, com os meios usuais de campo;

- Investigar a idade da sedimentação e/ou diagênese por meio de métodos geocronológicos;

- Comparar e correlacionar a bacia da Formação Camarinha com as demais bacias da transição Neoproterozóico-Eocambriano do Sul e Sudeste do Brasil, a fim de situá-la dentro de um contexto evolutivo mais amplo no âmbito dos sistemas orogênicos da Província Mantiqueira definida por Almeida et al. (1977);

- Propor algumas possíveis classificações atualizadas para a bacia em questão, discutindo os modelos evolutivos atualmente existentes e alternativos.

\subsection{LOCALIZACCÃO E VIAS DE ACESSO}

A bacia da Formação Camarinha, como inicialmente descrita por Muratori et al. (1967), aflora em duas porções de direção NE-SW no município de Campo Largo (PR), regiões de São Luiz do Purunã, Bateias e Itambé, a oeste e noroeste da cidade de Curitiba. As áreas aflorantes, referidas 
neste trabalho como Área Norte e Área Sul, são abrangidas no âmbito das folhas 1:50.000 de Campo Largo (SG.22-X-C-III-4) e Quero-Quero (SG.22-X-C-III-3), e das folhas 1:20.000 de $\mathrm{n}^{\circ}$ A052 e A055 a A060 da COMEC (PR), entre as coordenadas $49^{\circ} 30^{\prime}-49^{\circ} 47^{\prime}$ W e $25^{\circ} 15^{\prime}-25^{\circ} 30^{\prime} \mathrm{S}$ (Fig.1.1).

$\mathrm{O}$ acesso às áreas pode ser efetuado das seguintes maneiras (Fig.1.2 e Anexo II): na extremidade nordeste da Área Sul, por meio de estradas secundárias a partir da localidade de Bateias; na região central da Área Sul, por estradas secundárias partindo da BR-277 (trecho Curitiba-Palmeira) na cidade de Campo Largo e na Fábrica de Cimento Itambé; na extremidade sudoeste da Área Sul, por meio de estrada secundária também partindo da BR-277, na localidade de São Luiz do Purunã; na porção sul da Área Norte, por meio de estrada secundária que serve às localidades de Povinho de São João e Prata, a partir da estrada que liga a Jazida Rio Bonito à Fábrica de Cimento Itambé; e na região norte da mesma Área Norte, por estrada secundária que serve às localidades de Itambé, Rio Bonito e Itambezinho, próximo à Jazida Rio Bonito.

\subsection{MATERIAIS, MÉTODOS E TERMINOLOGIA EMPREGADOS}

Este trabalho foi parcialmente financiado por recursos do Projeto "Estudos Geológicos nos lineamentos Guapiara e Lancinha - Formação Camarinha - ", Processo no 1995/8810 1 da FAPESP (Fundação de Apoio à Pesquisa do Estado de São Paulo). A autora agradece a esta instituição e às demais entidades que apoiaram a confecção do trabalho, como IG-USP, Depto. de Geologia e Biblioteca do Setor de Tecnologia da UFPR e MINEROPAR (Minerais do Paraná S.A.), bem como aos colegas, professores e familiares que acompanharam e enriqueceram este processo com suas críticas, sugestões, discussões e apoio.

O trabalho iniciou-se com o levantamento de documentos pré-existentes sobre a Formação Camarinha, seu embasamento e bacias possivelmente correlatas, tais como bibliografia disponível, mapas e seções, dados geofísicos, fotografias aéreas e imagens de satélite. As bases topográficas utilizadas (escala 1:20.000 e 1:50.000) foram obtidas junto à COMEC (Coordenação da Região Metropolitana de Curitiba) e Biblioteca do Setor de Tecnologia da UFPR.

$O$ estudo da bacia da Formação Camarinha prosseguiu com o trabalho de análise e interpretação da imagem de satélite e das fotografias aéreas. A imagem de satélite foi fornecida nas bandas 3, 4 e 5 em CD-ROM pelo Instituto Nacional de Pesquisas Espaciais (INPE), e teve extraída para este trabalho uma janela referente à região de ocorrência da bacia da Formação Camarinha. Esta janela teve a Banda 5 submetida a um processo de Aumento Linear de Contraste, isto é, a um aumento do espalhamento dos valores de seus niveis de cinza no histograma respectivo, mediante uma função de transferência na forma de uma reta, conforme metodologia descrita em Crósta 


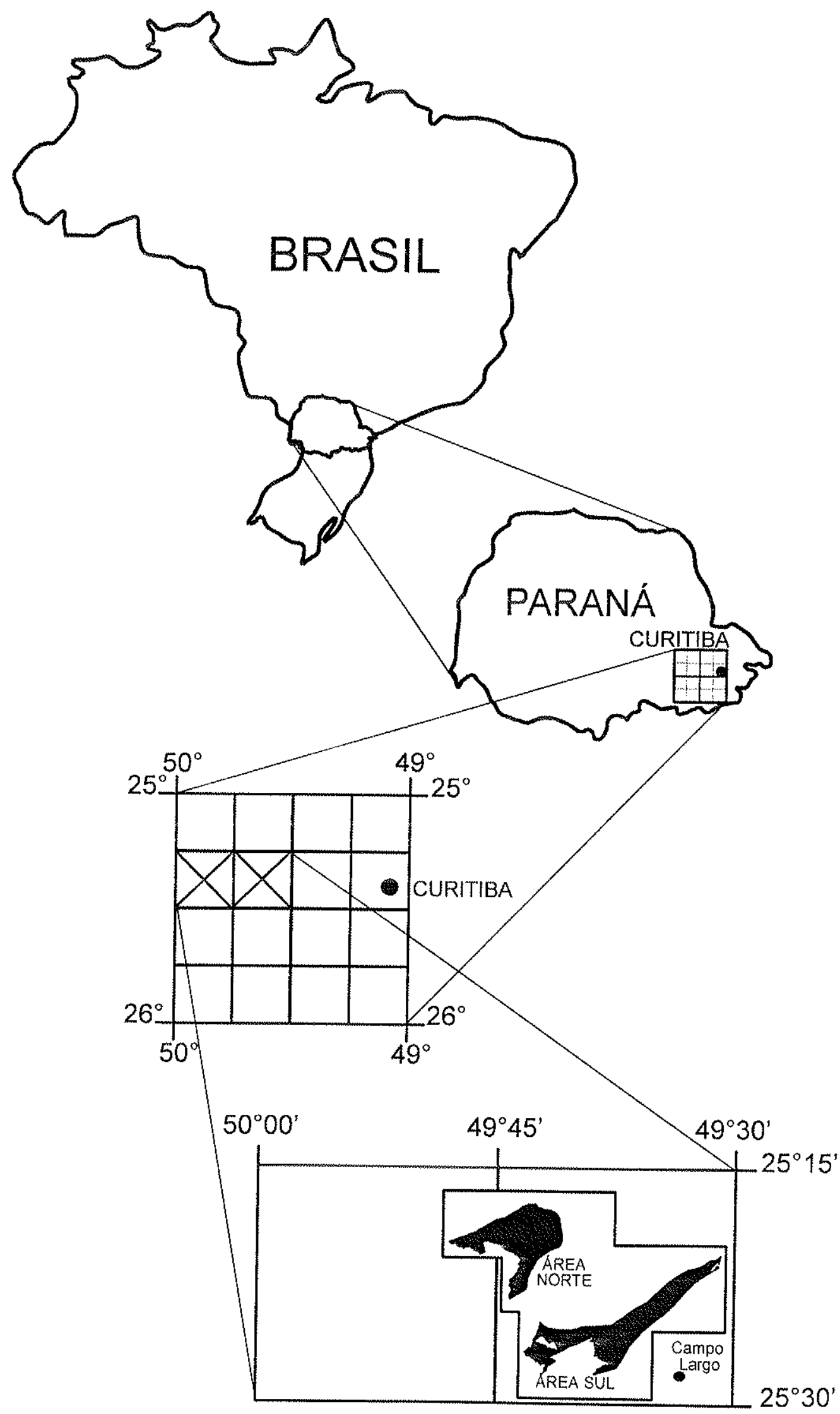

Fig.1.1: Localização e situação das áreas aflorantes da Formação Folha Quero-Quero Folha Campo Largo (SG.22-X-C-111-3) (SG.22-X-C-111-4) Camarinha no Estado do Paraná 


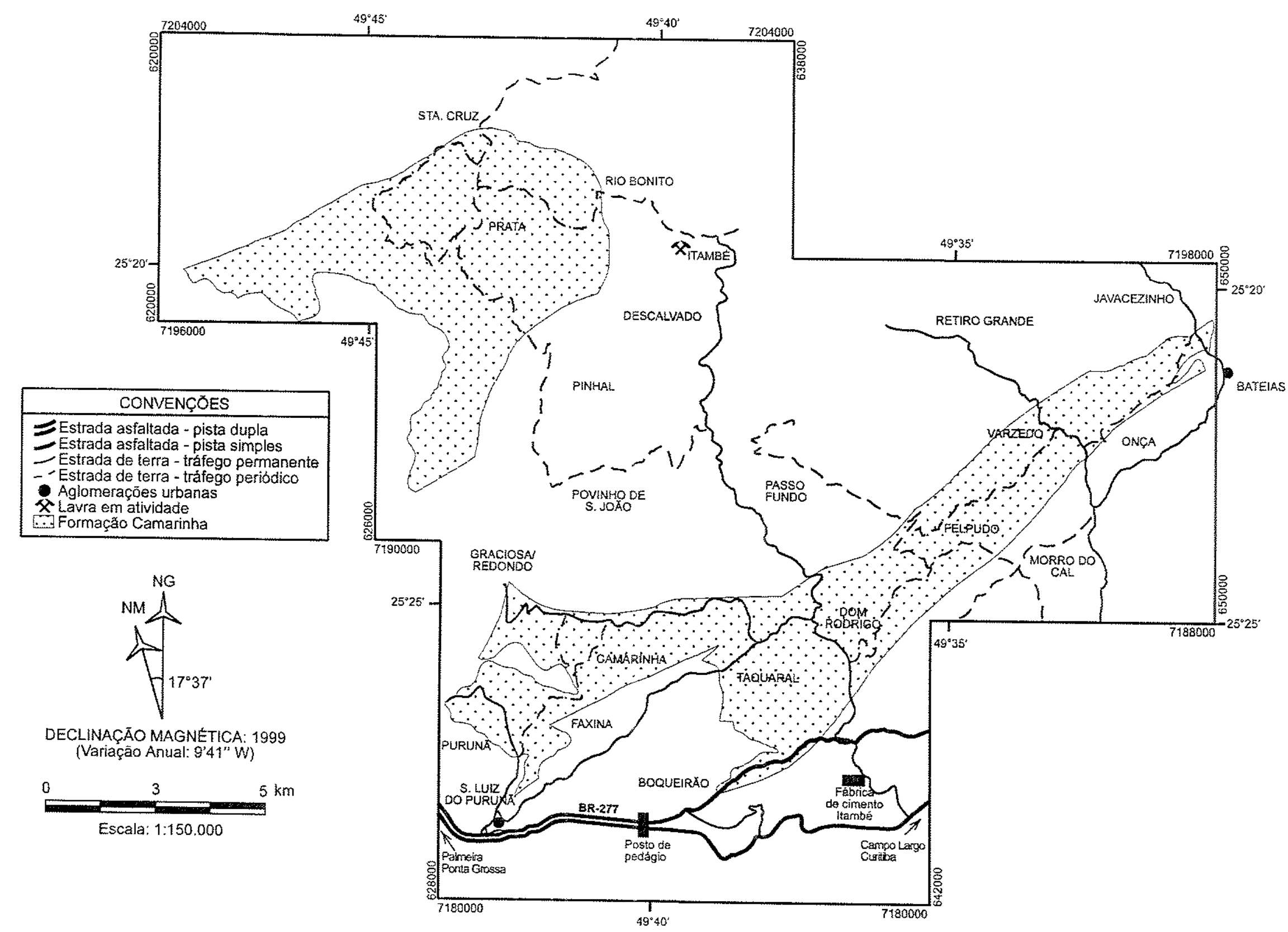

Fig.1.2: Vias de acesso às áreas aflorantes da Formação Camarinha no Estado do Paraná 
(1993) e Hasenack e Weber (1998). Este procedimento visa aumentar o contraste entre os diferentes pixels de uma imagem, possibilitando uma melhor visualização das estruturas pretendidas. Posteriormente, as três bandas foram superpostas para a geração de uma composição colorida. Em seguida, tanto a imagem com aumento de contraste como a composição colorida foram registradas ou georreferenciadas, isto é, tiveram atribuídas coordenadas equivalentes às coordenadas UTM do terreno (representadas nas bases topográficas utilizadas), a fim de serem corretamente orientadas do ponto de vista cartográfico. Finalmente, as imagens finais obtidas foram analisadas em conjunto com as fotografias aéreas, estas últimas confeccionadas pelo ITC-PR (Instituto de Terras e Cartografia do Paraná - 1980) em escala 1:25.000 e fornecidas pela MINEROPAR (Minerais do Paraná S.A.), visando o reconhecimento de grandes estruturas regionais nas imagens e seus detalhamentos em escala de mais detalhe nas fotografias aéreas.

Para a análise tanto da imagem de satélite como das fotografias aéreas, foi empregado o método proposto por Soares e Fiori (1976). Por este método, foram reconhecidos os elementos de textura ou elementos texturais (menores superfícies contínuas e homogêneas distinguíveis e repetidas na imagem fotográfica) e sua estrutura (padrão de arranjo dos elementos texturais no espaço). As características texturais e estruturais observadas foram: densidade, assimetria e presença de lineações (feições lineares retilíneas ou curvas) dos elementos texturais em geral; sinuosidade, angularidade e tropia dos elementos texturais da rede de drenagem; e quebras, alinhamentos e formas de encostas no relevo. Com a análise desses caracteres e do tipo e grau de estruturação dos mesmos, delimitaram-se zonas homólogas, onde elementos de mesmo padrão textural e estrutural repetem-se com regularidade. As zonas homólogas, por sua vez, foram analisadas e classificadas de acordo com a densidade, forma e tropia (altas, moderadas, baixas ou nulas) dos elementos que as constituem, delimitando zonas fotolitológicas, as quais são constituídas por rochas de propriedades similares.

No processo interpretativo, os elementos texturais analisados (lineações de relevo e drenagem, quebras topográficas e alinhamentos) e sua estruturação representam feições como traços de acamamento, foliação ou fraturas, corpos mais resistentes ou menos resistentes, contatos erosivos ou litológicos, falhas preenchidas ou não. Assim, através da fotointerpretação, foi possível determinar zonas fotolitológicas distintas dentro da Formação Camarinha, cuja caracterização foi completada através dos trabalhos de campo.

Os trabalhos de campo deram-se em diversas etapas, a partir das quais foram gerados os mapas apresentados neste trabalho (Mapa Geológico, Anexo I, e mapas de localização de afloramentos das áreas Sul e Norte, Anexos II e III). Nestes trabalhos de campo, foram levantados perfis transversais e longitudinais às zonas aflorantes da Formação Camarinha, além de seções colunares verticais, visando: a delimitação da distribuição espacial e espessura das diferentes 
associações litológicas que constituem a formação; as relações da mesma com seu embasamento; coleta de amostras para análise petrográfica, difratométrica e geocronológica dos sedimentos, a fim de conhecer sua composição, proveniência, evolução e idade; coleta de dados estratigráficos (empilhamento e espessura de camadas, tipos de fácies, caracterização de estruturas sedimentares e medição de sentidos de paleocorrentes), para a interpretação dos ambientes deposicionais vigentes e evolução dos mesmos; e coleta de dados estruturais (atitudes de acamamento, fraturamento, foliações e estiramento de clastos), visando o estabelecimento do tipo de deformação sofrida.

Os mapas gerados foram confeccionados a partir da integração dos dados de fotointerpretação e campo, tendo sido digitalizados sobre as bases topográficas disponíveis. As convenções utilizadas foram extraídas de Lahee (1952), Compton (1985), Tucker (1989), Silva (1994), CPRM (1997) e IBGE (1998). A escala de 1:50.000 foi considerada a mais adequada para uma representação completa dos dados litológicos, estratigráficos e estruturais obtidos, não havendo dados em quantidade e densidade suficientes para uma representação em escala de mais detalhe.

$\mathrm{O}$ reconhecimento e a interpretação das estruturas sedimentares identificadas seguiram as descrições e critérios estabelecidos em Reineck e Singh (1975), Collinson e Thompson (1989) e Ricci-Lucchi (1996). Os sentidos de paleocorrentes tiveram seus valores corrigidos para o plano horizontal a partir do rebatimento em estereograma dos valores de mergulho das camadas onde foram medidos, respeitando-se a relação angular entre as direções da linha representativa do sentido de paleocorrente e as direções da camada onde ocorrem, conforme procedimento descrito em Collinson e Thompson (1989) e Tucker (1989). Para a análise de paleocorrentes, procurou-se seguir os preceitos recomendados por Potter e Pettijohn (1977), Selley (1982), Assine (1994, 1996) e Miall (1990). Já a caracterização das fácies seguiu o esquema proposto inicialmente por Miall (1977, 1978a,b, 1990), com modificações introduzidas por McPherson et al. (1987, 1988), Fritz e Moore (1988), e Blair e McPherson (1992) (Quadro 1.1). As fácies foram analisadas segundo suas características composicionais, texturais e estruturais, que as tornam características de processos deposicionais específicos, cujo conjunto gera uma associação ou assembléia de fácies diagnóstica dos sistemas deposicionais vigentes à época da sedimentação.

A interpretação das fácies identificadas e análise dos sistemas deposicionais possíveis baseou-se na literatura geral sobre o assunto, representada por Rigby e Hamblin (1972), Reineck e Singh (1975), Scholle e Spearing (1982), Galloway e Hobday (1983), Allen e Allen (1990), Miall (1990), Einsele (1992), Walker e James (1992), Plint (1995), Boggs Jr. (1995) e Reading (1996). Foram feitos estudos mais aprofundados sobre processos e sistemas específicos, tais como depósitos de fluxos gravitacionais e correntes de turbidez, relativos a suas origens, características texturais e estruturais e ambientes de ocorrência (Kersey e Hsü, 1976; Mutti e Ricci-Lucchi, 1978; Gloppen e 


\begin{tabular}{|c|c|c|c|}
\hline CÓDIGO & DESCRICÃO & ESTRUTURAS & INTERPRETACĀO \\
\hline Gms & \begin{tabular}{|c|}
$\begin{array}{c}\text { Conglomerados maciços e } \\
\text { sustentados por matriz }\end{array}$ \\
\end{tabular} & Nenhuma & Depósitos de fluxos de detritos \\
\hline $\begin{array}{l}\text { Gmu } \\
\text { (Fritze } \\
\text { Moore, } \\
1988 \text { ) } \\
\end{array}$ & \begin{tabular}{|c|} 
Conglomerados maciços a \\
gradacionais, mal \\
selecionados e \\
sustentados por clastos \\
\end{tabular} & $\begin{array}{l}\text { Gradação normal ou inversa } \\
\text { incipiente, sem fabric ou } \\
\text { imbricação }\end{array}$ & Depósitos de fluxos de detritos \\
\hline $\mathrm{Gm}$ & $\begin{array}{c}\text { Conglomerados maciços a } \\
\text { incipientemente } \\
\text { estratificados }\end{array}$ & $\begin{array}{l}\text { Estratificaçăo horizontal, } \\
\text { imbricação }\end{array}$ & $\begin{array}{l}\text { Barras longitudinais, depósitos residuais, } \\
\text { depósitos de peneiramento, stream flow } \\
\text { hiperconcentrado }\end{array}$ \\
\hline $\begin{array}{c}\text { Gm } \\
\text { (McPherson } \\
\text { et al., 1987, } \\
1988 \text { ) } \\
\end{array}$ & $\begin{array}{l}\text { Conglomerados maciços } \\
\text { sustentados por clastos }\end{array}$ & Nenhuma & $\begin{array}{c}\text { Depósitos de fluxos de detritos; } \\
\text { Preenchimento de canais (Blair e } \\
\text { McPherson, 1992) }\end{array}$ \\
\hline $\begin{array}{c}\text { Gh } \\
\text { (McPherson } \\
\text { et al., 1987, } \\
1988) \\
\end{array}$ & $\begin{array}{l}\text { Conglomerados } \\
\text { estratificados }\end{array}$ & $\begin{array}{l}\text { Estratificação horizontal, } \\
\text { imbricação }\end{array}$ & $\begin{array}{c}\text { Barras longitudinais, depósitos residuais, } \\
\text { depósitos de peneiramento, stream flow } \\
\text { hiperconcentrado, preenchimento de } \\
\text { canais (?) }\end{array}$ \\
\hline Gt & $\begin{array}{l}\text { Conglomerados } \\
\text { estratificados }\end{array}$ & Estratificação cruzada acanalada & Preenchimento de canais \\
\hline Gp & $\begin{array}{c}\text { Conglomerados } \\
\text { estratificados }\end{array}$ & Estratificação cruzada planar & $\begin{array}{c}\text { Barras linguóides ou migração deltaica a } \\
\text { partir de antigas barras } \\
\end{array}$ \\
\hline St & \begin{tabular}{|c|}
$\begin{array}{c}\text { Arenitos médios a grossos } \\
\text { e conglomeráticos }\end{array}$ \\
\end{tabular} & Estratificação cruzada acanalada & $\begin{array}{c}\text { Dunas subaquosas em regime de fluxo } \\
\text { inferior }\end{array}$ \\
\hline $\mathrm{Sp}$ & $\begin{array}{c}\text { Arenitos médios a grossos } \\
\text { e conglomeráticos }\end{array}$ & Estratificação cruzada tabular & $\begin{array}{l}\text { Barras transversais, linguóides, e dunas } \\
\text { subaquosas em regime de fluxo inferior }\end{array}$ \\
\hline $\mathrm{Sr}$ & $\begin{array}{l}\text { Arenitos muito finos a } \\
\text { grossos }\end{array}$ & Marcas onduladas & Ondulações em regime de fluxo inferior \\
\hline $\mathrm{Sh}$ & $\begin{array}{c}\text { Arenitos muito finos a } \\
\text { grossos e conglomeráticos }\end{array}$ & $\begin{array}{l}\text { Laminação horizontal, lineação } \\
\text { de partição ou fluxo }\end{array}$ & $\begin{array}{c}\text { Fluxo planar em regimes de fluxo } \\
\text { inferior e superior }\end{array}$ \\
\hline SI & Arenitos finos & $\begin{array}{c}\text { Estratificação cruzada de baixo } \\
\text { ângulo }\left(<10^{\circ}\right)\end{array}$ & $\begin{array}{l}\text { Preenchimento de estruturas de } \\
\text { escavacăo, crevasse sploys, antidunas }\end{array}$ \\
\hline $\mathrm{Se}$ & Arenitos com intraclastos & Estratificação cruzada incipiente & $\begin{array}{c}\text { Preenchimento de estruturas de } \\
\text { escavação }\end{array}$ \\
\hline Ss & $\begin{array}{c}\text { Arenitos finos a grossos e } \\
\text { conglomeráticos }\end{array}$ & $\begin{array}{l}\text { Estratificação cruzada em } \\
\text { escavaçōes largas e rasas }\end{array}$ & $\begin{array}{l}\text { Preenchimento de estruturas de } \\
\text { escavação } \\
\end{array}$ \\
\hline Sse, She,Spe & Arenitos & Idem Ss, Sh e Sp & Depósitos eólicos \\
\hline Fl & Arenitos, siltitos e lamitos & Laminação fina, ondulações & $\begin{array}{l}\text { Depósitos de transbordamento ou } \\
\text { dissipacão de enchentes, decantação }\end{array}$ \\
\hline $\begin{array}{l}\text { Fh (Fritze } \\
\text { Moore, } \\
\text { 1988) } \\
\end{array}$ & Siltitos, lamitos & Laminação horizontal incipiente & Fluxo planar, carpetes de tração \\
\hline Fsc & Siltitos, lamitos & Laminada a maciça & Depósitos de pântanos \\
\hline Fcf & Siltitos, lamitos & $\begin{array}{c}\text { Maciça, com moluscos de água } \\
\text { doce }\end{array}$ & Depósitos de pântanos \\
\hline $\mathrm{Fm}$ & Lamitos, siltitos & $\begin{array}{l}\text { Maciça, com gretas de } \\
\text { ressecação } \\
\end{array}$ & Depósitos de transbordamento \\
\hline $\mathrm{Fr}$ & Siltitos, lamitos & Marca de raizes & Níveis pelíticos \\
\hline $\mathrm{C}$ & $\begin{array}{l}\text { Carvão, lamas } \\
\text { carbonáticas }\end{array}$ & $\begin{array}{l}\text { Plantas, filmes de lama, } \\
\text { paleossolos, zonas orgânicas }\end{array}$ & $\begin{array}{c}\text { Depósitos de pântanos, transbordamento } \\
\text { de lagos }\end{array}$ \\
\hline $\mathrm{P}$ & Carbonatos & Feições pedogenéticas & Solos \\
\hline
\end{tabular}

Quadro 1.1: Esquema de codificação e descrição de litofácies fluviais (modificado de Miall, 1977, 1978a,b, 1990; McPherson et al., 1987, 1988; Fritz e Moore, 1988; Blair e McPherson, 1992) 
Steel, 1981; Lowe, 1982; Nemec e Steel, 1984; Pickering et al., 1986; Fritz e Moore, 1988; Ghibaudo, 1992; Walker, 1992), e depósitos de leques aluviais, fandeltas e deltas, relativos a processos atuantes, fácies resultantes e contexto geológico e geotectônico (Bull, 1972; Ethridge e Flores, 1981; Rachocki, 1981; Coleman e Prior, 1982; Nilsen, 1982; Koster e Steel, 1984; Blair, 1987; Nemec e Steel, 1988; Colella e Prior, 1990; Rachocki e Church, 1990; Wescott e Ethridge, 1990; Bhattacharya e Walker, 1992; Miall, 1992; Marzo e Puigdefábregas, 1993; Blair e McPherson 1994a,b; Collinson, 1996; Reading e Collinson, 1996).

A análise petrográfica consistiu na descrição de 22 lâminas delgadas entre arenitos, conglomerados e brechas da Formação Camarinha, visando uma análise dos tipos litológicos, suas características texturais, composição de arcabouço, verificação da ocorrência de matriz, e tipos de cimento e de alteração visíveis. O baixo número de lâminas confeccionadas deve-se ao elevado grau de alteração intempérica das rochas, o que limita a quantidade de amostras em boas condições para serem laminadas. As características texturais analisadas foram tamanho de grãos, seleção (distribuição dos diferentes tamanhos) e arredondamento (forma) dos clastos e grãos características estas compiladas e descritas em Dorado (1989). O estudo da composição mineralógica visando uma classificação modal dos litotipos e análise de sua proveniência seguiu descrições e critérios expostos em Scholle (1979) e Adams et al. (1992).

Tanto para a classificação dos litotipos arenosos como para sua análise de proveniência, foi efetuada contagem modal de 1000 pontos de arcabouço em uma malha de $0,3 \times 0,3 \mathrm{~mm}$ em seis lâminas selecionadas. A classificação foi feita segundo Dott Jr. (1964) e Peetijohn et al. (1987) (Fig.1.3), classificações estas que têm a vantagem de levar em conta tanto a maturidade composicional como textural dos sedimentos. A análise do tipo de alteração ocorrida seguiu critérios de paragêneses minerais específicas descritas em Burnham (1962), Hemley e Jones (1964), Meyer e Hemley (1967), Pirajno (1992) e Thompson et al. (1996), enquanto que a interpretação dos processos diagenéticos atuantes baseou-se em características apresentadas em Boggs Jr. (1995) (Quadro 1.2). Já a análise de proveniência em termos de ambiente geotectônico foi efetuada com base na composição dos sedimentos segundo critérios estabelecidos por Dickinson et al. (1983) e Dickinson (1985), e segundo petrofácies definidas por Dickinson (1988).

Para uma análise qualitativa da composição de argilominerais presentes nos sedimentos mais finos da Formação Camarinha, foi efetuada difratometria de Raios-X em fração fina $(<2 \mu)$ de três amostras coletadas em afloramentos com uma certa continuidade lateral de níveis lamíticos, o que permitiu a coleta de quantidades suficientes tanto para a análise difratométrica como para posterior análise geocronológica. Essas amostras foram moídas e submetidas à separação da fração fina por decantação no Laboratório de Geoquímica do IG-USP. As frações finas obtidas foram então 

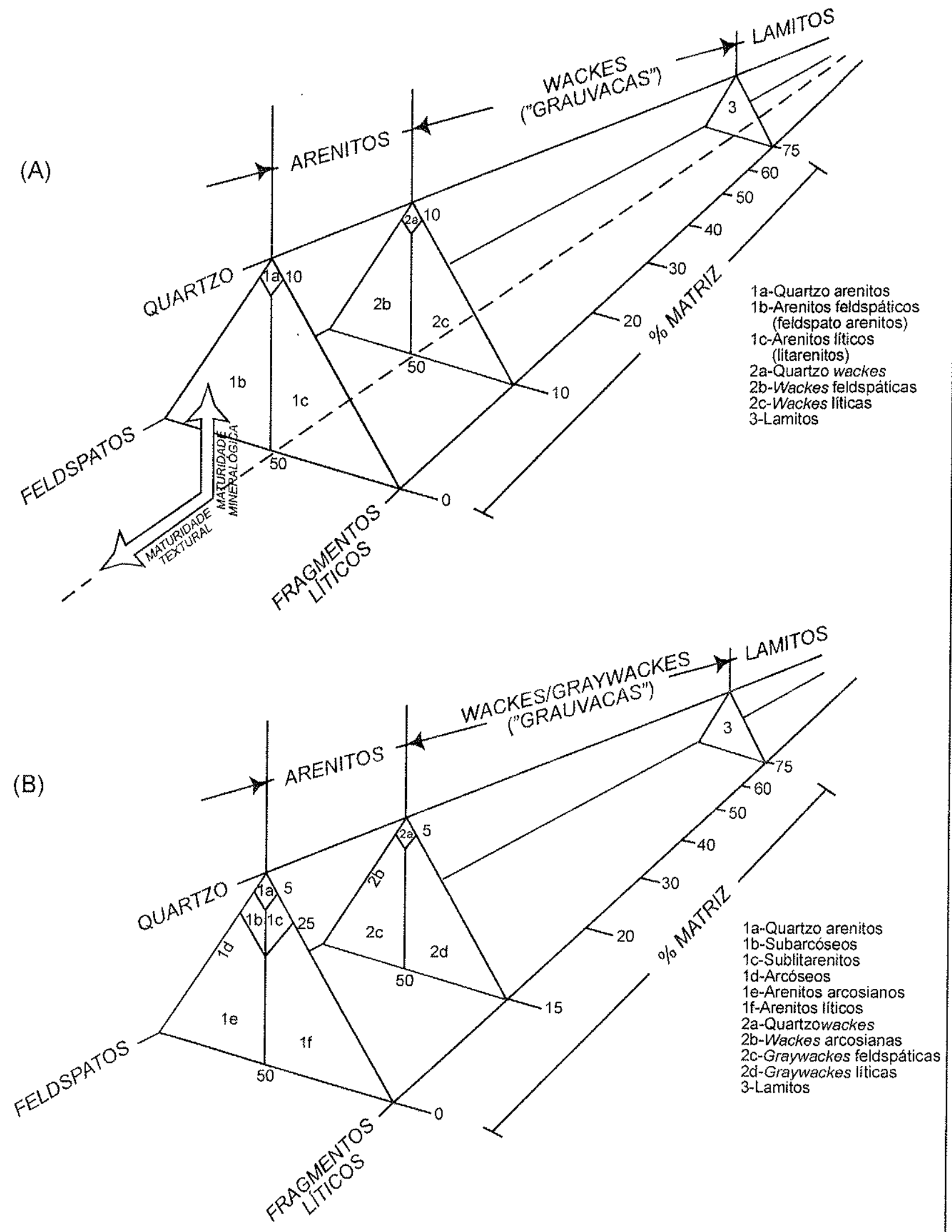

Fig. 1.3: Classificação modal de arenitos segundo Dott (1964) (A) e Pettijohn et al. (1987) (B) 


\begin{tabular}{|c|c|c|c|}
\hline & $\begin{array}{l}\text { ESTÁGIO } \\
\text { IAGENÉTICO }\end{array}$ & $\begin{array}{c}\text { PROCESSOS } \\
\text { DIAGENETICOS }\end{array}$ & RESULTADOS \\
\hline \multirow{8}{*}{ 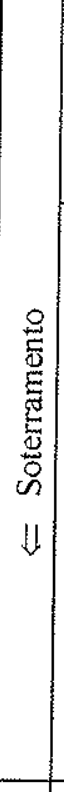 } & \multirow[b]{2}{*}{ Eodiagênese } & Bioturbação & $\begin{array}{c}\text { Destruição de estruturas sedimentares primárias, formação de } \\
\text { estruturas variegadas }\end{array}$ \\
\hline & & $\begin{array}{l}\text { Cimentação e } \\
\text { substituição }\end{array}$ & $\begin{array}{l}\text { Formação de pirita (ambientes redutores) ou óxidos de ferro } \\
\text { (ambientes oxidantes); precipitação de intercrescimentos de quartzo } \\
\text { e feldspatos, cimento carbonático, caulinita ou clorita }\end{array}$ \\
\hline & \multirow{6}{*}{ Mesodiagênese } & Compactação física & $\begin{array}{l}\text { Empacotamento mais fechado, redução da porosidade e diminuição } \\
\text { de espessura do acamamento }\end{array}$ \\
\hline & & $\begin{array}{l}\text { Compactação química } \\
\text { (dissolução por pressão) }\end{array}$ & $\begin{array}{l}\text { Dissolução parcial de grãos silicáticos, redução de porosidade e } \\
\text { diminuição de espessura do acamamento }\end{array}$ \\
\hline & & Cimentação & $\begin{array}{l}\text { Precipitação de cimento carbonático (calcita) e silicático (quartzo) } \\
\text { com redução de porosidade }\end{array}$ \\
\hline & & Dissolução por fluidos & $\begin{array}{l}\text { Remoção por dissolução de cimentos carbonáticos e grãos } \\
\text { silicáticos do arcabouço; criação de porosidade secundária pela } \\
\text { destruição preferencial de minerais menos estáveis }\end{array}$ \\
\hline & & Substituições minerais & $\begin{array}{l}\text { Substituição parcial a completa de alguns grãos silicáticos e matriz } \\
\text { argilosa por novos minerais (ex. substituição de feldspatos por } \\
\text { calcita) }\end{array}$ \\
\hline & & $\begin{array}{c}\text { Autigênese de minerais } \\
\text { argilosos }\end{array}$ & $\begin{array}{c}\text { Alteração de um tipo de mineral argiloso para outro (ex. esmectita } \\
\text { por illita ou clorita e caulinita para illita) }\end{array}$ \\
\hline 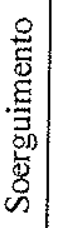 & Telodiagênese & $\begin{array}{l}\text { Dissolução, } \\
\text { substituição, oxidação }\end{array}$ & $\begin{array}{c}\text { Dissolução de cimentos carbonáticos, alteração de feldspatos para } \\
\text { minerais de argila, oxidação de carbonatos de ferro para óxidos de } \\
\text { ferro, oxidação de pirita para gipso, dissoluçăo de minerais menos } \\
\text { estáveis (ex. piroxênios e anfibólios) }\end{array}$ \\
\hline
\end{tabular}

Quadro 1.2: Processos e mudanças diagenéticas que ocorrem em rochas terrígenas durante o soterramento (Fonte: Boggs Jr., 1995)

analisadas em um difratômetro D5000 (Siemens/Brucker) disponível também no IG-USP, em lâminas orientadas e sem aquecimento nem impregnação por etileno-glicol. Os difratogramas obtidos foram interpretados segundo os critérios para identificação dos picos característicos de cada grupo de argilominerais segundo Santos (1975) e Eslinger e Pevear (1988).

A datação geocronológica foi efetuada pelo método $\mathrm{Rb}$-Sr em amostras dos mesmos pontos onde foram coletadas as amostras para análise de difratometria de Raios-X. A amostragem seguiu as recomendações enfatizadas por Thomaz Filho (1976) para coleta de amostras de cerca de $200 \mathrm{~g}$ cada uma, com composição argilosa, não muito afastadas entre si e pertencentes a uma mesma camada do pacote sedimentar. Cada amostra foi acondicionada separadamente, sendo submetida à mesma separação da fração fina $(<2 \mu)$ feita para as amostras analisadas por Difratometria de Raios$X$. Posteriormente à análise difratométrica, as amostras foram secas e submetidas à análise semiquantitativa por fluorescência de Raios-X no CPGEO (Centro de Pesquisas Geocronológicas) do IG-USP, visando uma determinação preliminar dos teores de Rb e Sr. Após a análise semiquantitativa, as amostras selecionadas segundo a melhor distribuição foram encaminhadas aos processos de diluição isotópica e espectrometria, para geração das futuras isócronas. 
Os dados estruturais foram analisados por métodos tradicionais, a partir de estereogramas de acamamento, fraturas e foliações em rede de Schmidt-Lambert, cujos procedimentos de construção e interpretação podem ser encontrados em Ragan (1980), Davis (1984) e Rowland e Duebendorfer (1994). A interpretação das estruturas detectadas baseou-se na comparação com modelos de estruturas geradas em zonas de transcorrência, descritos por autores como Wilcox et al. (1973) e Sylvester (1988), que as compilaram no chamado Modelo de Riedel. A análise da deformação de clastos em rochas conglomeráticas da Formação Camarinha foi feita segundo o método $\mathrm{Rf} / \phi$ exposto em Ramsay e Huber (1993) e Fiori (1997). Por este método, os eixos X (maior) e Z (menor) dos clastos são medidos em campo, fotografias ou amostras orientadas, bem como o ângulo $\phi$ do eixo $\mathrm{X}$ de cada clasto com uma linha de referência qualquer. Calculam-se então as razões finais de estiramento $\mathrm{Rf}=\mathrm{X} / \mathrm{Z}$ de cada clasto, que são plotadas em um gráfico $\mathrm{Rf} \times \mathrm{x} \phi$ sobre papel mono-log. Os pontos resultantes são submetidos a uma contagem sobre uma malha quadriculada, contagem esta que, devidamente convertida em porcentagens, gera um gráfico de isocurvas a partir do qual é calculada a Razão de Deformação $(\mathrm{Rs}=\sqrt{R f m a ́ x \times R f m i ́ n})$. Esta é a razão que dá a medida do estiramento médio do eixo $X$ do elipsóide de deformação para eixo $Z=1$, fornecendo assim $o$ elipsóide médio (com eixos proporcionais) da deformação sofrida na região analisada.

Para a interpretação e determinação final do tipo de bacia na qual depositou-se a Formação Camarinha, foram utilizadas as classificações propostas por Miall (1990), Einsele (1992) e Ingersoll e Busby (1995), consideradas bastante adequadas por sua atualidade e por levarem em conta as mais diversas situações possíveis com relação à posição das bacias quanto às margens de placas e quanto ao estágio evolutivo da movimentação das mesmas, conforme critérios anteriormente estabelecidos por Kingston et al. (1983). Os possíveis modelos de bacias para o presente trabalho foram estudados levando-se em conta o provável contexto geotectônico do embasamento da Formação Camarinha e a tectônica formadora, preenchimento sedimentar, tectônica deformadora e provável idade da mesma. Foram analisados modelos propostos por Kingston et al. (1983), Allen e Allen (1990), Miall (1990), Einsele (1992) e Busby e Ingersoll (1995), com especial ênfase para bacias de strikeslip ou oblique-slip (Ballance e Reading, 1980; Mann et al., 1983; Biddle e Christie--Blick, 1985; Marzo e Anadón, 1988; Nilsen e Sylvester, 1995), bacias de foreland (Allen e Homewood, 1986; Allen et al., 1986; Jordan, 1995; Miall, 1995) e bacias de piggyback (Ori e Friend, 1984; RicciLucchi, 1985, 1986; Beer et al., 1990; Cipollari e Cosentino, 1993; Pieri et al., 1994; Jordan, 1995; Miall, 1995; Nilsen e Sylvester, 1995). A influência do ambiente geotectônico e da tectônica atuante sobre o preenchimento sedimentar foi estudada segundo análises apresentadas em RicciLucchi (1985), Kleinspehn e Paola (1988), Nemec e Steel (1988), Massari e Colella (1988), Allen e Allen (1990), Einsele (1992), Frostick e Steel (1993) e Busby e Ingersoll (1995). 
Na tentativa de discriminar melhor as sucessões litológicas constituintes da Formação Camarinha e observar suas diferenças com relação a seu embasamento, procurou-se usar dados geofísicos de magnetometria e gamaespectrometria disponíveis pelo projeto Serra do Mar-Sul (CPRM-GEOFOTO, 1981). Os dados foram processados, submetidos a filtragens e dispostos em mapas de contorno diversos, não fornecendo, entretanto, informações consideradas relevantes para o pretendido, uma vez que o levantamento utilizado é aéreo e de caráter eminentemente regional, não permitindo visualizar detalhes de diferenças composicionais dentro da Formação Camarinha e nem mesmo discriminá-la seguramente de seu embasamento. Tais relações possam talvez vir a ser futuramente obtidas com o efetuamento de levantamentos terrestres em escala de mais detalhe, complementados por outros métodos, como gravimetria e análise de dados sísmicos, se existentes e disponíveis. 


\section{TRABALHOS ANTERIORES E GEOLOGIA REGIONAL}

\subsection{BACIA DA FORMACÃO CAMARINHA}

Embora existissem menções anteriores à ocorrência de rochas conglomeráticas e arcosianas na região da Formação Camarinha, a mesma somente foi cartografada pela primeira vez como tal por Muratori et al. (1965) e Fuck et al. (1965), nas folhas geológicas de Campo Largo e QueroQuero, elaboradas pela Comissão da Carta Geológica do Paraná. Foi em seguida descrita nas correspondentes notas explicativas elaboradas por Muratori (1966) e Fuck (1966), e analisada em mais detalhes por Muratori et al. (1967). Estes autores descreveram a Formação Camarinha como uma seqüência dobrada e não metamórfica de rochas sedimentares clásticas castanho escuras a castanho-avermelhadas, constituídas por siltitos com intercalações de conglomerados polimíticos gradacionais, arcóseos e argilitos, apresentando direção geral de camadas em torno de $\mathrm{N} 40^{\circ}-50^{\circ} \mathrm{E}$ e mergulhos variando entre $30^{\circ}$ e $80^{\circ}$. A espessura da formação foi estimada em mais de $1000 \mathrm{~m}$.

Os siltitos foram descritos pelos autores como sendo a litologia predominante na formação, variando de siltitos arenosos, às vezes conglomeráticos, a siltitos argilosos que passam eventualmente a argilitos. Os autores também descreveram laminação plano-paralela e intercalações lenticulares de arenitos arcosianos e arcóseos com microestratificações cruzadas resultantes das migrações de marcas onduladas. Já os conglomerados foram descritos como sendo polimíticos e imaturos com estratificação gradacional, ocorrendo na forma de lentes intercaladas nos siltitos e constituídos por seixos subangulosos a subarredondados de filito, calcário, dolomito, quartzito, quartzo de veio, granito, etc., em matriz lítica a arcosiana.

Ainda segundo os mesmos autores, a Formação Camarinha seria uma seqüência de "natureza molássica", depositada por correntes de turbidez a partir de correntes de lama adentrando um ambiente marinho raso e tectonicamente instável. A ritmicidade dos depósitos indicaria ciclicidade deposicional relacionada a pulsos tectônicos de soerguimento nas fases finais da orogênese. $O$ caráter imaturo e mal selecionado dos sedimentos seria indicativo de área-fonte próxima, com pouco transporte e retrabalhamento do material sedimentar. Uma contribuição subaérea na deposição foi proposta por Bigarella e Mousinho (1965), na forma de sheet-floods gerando movimentos de massa em área-fonte emersa e soerguida, adentrando o ambiente subaquoso e passando então a comportar-se como correntes de lama.

A tectônica deformadora da Formação Camarinha foi descrita por Fuck (1966) como manifestando-se na forma de homoclinais, com camadas de direção ENE-WSW mergulhando entre $45^{\circ}$ e $70^{\circ}$ para SSE, na porção norte da formação; e anticlinais e sinclinais com eixos de direção NE-SW e caimento para SW, na região de Campo Largo, porção sul da formação, O paralelismo 
com atitudes registradas no Grupo Açungui foi interpretado pelo autor como resultante de retomada de um eixo de dobramento preexistente.

Com base na ausência de metamorfismo e em contato por discordância angular com o Grupo Açungui (Pré-Cambriano), Muratori et al. (1967) posicionaram a Formação Camarinha como posterior a este último. De acordo com esses autores, o contato por discordância angular com os arenitos da Formação Furnas (Devoniano da Bacia do Paraná), a ausência de manifestações vulcânicas ácidas semelhantes às ocorridas no Ordoviciano e a ocorrência de dobramentos fechariam a situação da Formação Camarinha no Cambriano ou Eocambriano.

Posteriormente, Almeida (1969) interpretou as "bacias molássicas" do sul do Brasil, entre as quais a bacia da Formação Camarinha, como pertencentes ao "estágio de transição da Plataforma Brasileira", entre o Pré-Cambriano Superior e o Eopaleozóico, resultantes do soerguimento e erosão das "cadeias montanhosas" formadas no Ciclo Brasiliano.

Popp (1972), com base em três seções geológicas detalhadamente descritas, dividiu a Formação Camarinha em uma fácies conglomerática superior e uma fácies síltica inferior: a fäcies conglomerática seria constituída por conglomerados, arcóseos conglomeráticos e arcóseos médios a grosseiros ritmicamente intercalados, com seixos subarredondados e angulosos de constituições variadas em matriz arcosiana e freqüentes estruturas gradacionais; já a fácies síltica seria constituída por siltitos e arcóseos finos a médios, raramente conglomeráticos, com freqüentes laminações paralelas e eventuais ocorrências de marcas onduladas e de corrente associadas, e estruturas maciças e gradacionais. Outras estruturas identificadas pelo autor foram laminações cruzadas, convolutas e marcas de escorregamento. Segundo o mesmo autor, essas fácies teriam sido depositadas por "correntes mais fracas (menos turbulentas) e menos profundas do que as correntes de turbidez formadoras de Seqüências de Bouma". Com base em estruturas primárias, a áreamfonte foi localizada pelo autor como situando-se a NE, sendo constituída por rochas do Grupo Açungui. O mesmo autor estimou a espessura da Formação Camarinha em $4000 \mathrm{~m}$ e sugeriu a ocorrência de atividade tectônica sin-sedimentar.

Popp (1972) ainda descreveu as dobras ocorrentes como sendo "isoclinais com convergência para sudeste, constituídas por sinclinais e anticlinais de pequena abertura", tendo as camadas direção geral NE-SW e mergulhos de $28^{\circ}$ a $83^{\circ}$ para NW e SE.

Polidoro e Gonçalves (1984), Ciguel e Godoy (1985) e Góis e Horstmann (1985) efetuaram mapeamentos parciais na região correspondente à Área Sul da Formação Camarinha, sendo os primeiros a levantarem a possibilidade de deposição para a mesma em bacia de graben póstectônico não afetado por dobramentos, e sim por basculamentos de blocos relacionados aos falhamentos. 
Soares (1987) descreveu a Formação Camarinha como constituída por conglomerados e arenitos conglomeráticos imaturos gradando para siltitos e lamitos em sua porção basal, lamitos com arenitos intercalados culminando com siltitos e lamitos na porção intermediária, e conglomerados lamíticos e polimíticos na porção superior, sem relação definida com os estratos inferiores. Segundo este autor, os pacotes da porção basal teriam sido depositados em ambientes de leques aluviais e deltaicos, e os da porção intermediária em ambientes litorâneos e de leque distal. $\mathrm{O}$ mesmo autor registrou a ocorrência de anquimetamorfismo nas rochas da Formação Camarinha, na forma de foliação ardosiana nos sedimentos pelíticos. Esta foliação seria "plano-axial de dobras verticais semifechadas a abertas", não paralela ao acamamento, portanto com as mesmas características da deformação pós-cavalgamento que atuou sobre o Grupo Açungui. Soares (1987, 1988) ainda considerou a Formação Camarinha como correlacionável à Seqüência Antinha (PR), fato este descartado no presente trabalho com base em diferenças petrológicas e estruturais entre as duas unidades. O mesmo autor considerou a Formação Camarinha como constituindo "uma bacia molássica foreland de retro-arco, tardi-orogênica, tardi-colisional ou precoce, originada por flexão devido a sobrecarga litosférica relacionada ao empilhamento tectônico". O ambiente do arco magmático seria, no caso, representado pelo Complexo Granítico Três Córregos.

Moritz Jr. e Fiori (1987) analisaram a deformação sofrida pelos conglomerados da Formação Camarinha ao longo da Falha da Lancinha (direção $\mathrm{N} 50^{\circ} \mathrm{E}$ na região), verificando uma direção preferencial $\mathrm{N} 70-80^{\circ} \mathrm{E}$ com pouco caimento do eixo $\mathrm{X}$ do elipsóide de deformação, eixo $Z$ horizontal e perpendicular a $X$, e eixo $Y$ vertical. Essa deformação seria pouco intensa, restrita a uma faixa de aproximadamente $500 \mathrm{~m}$ ao sul da Falha da Lancinha e possivelmente mais $500 \mathrm{~m}$ também ao norte da mesma. A posição do eixo X seria compatível com uma movimentação lateral esquerda (sinistral), com deslocamento mínimo de $800 \mathrm{~m}$. Os autores relacionaram este deslocamento a uma reativação mesozóica da Falha da Lancinha, uma vez que o mesmo deslocamento foi detectado em diques de diabásio a noroeste de Bateias. No entanto, Fassbinder (1990) associou o deslocamento a uma movimentação lateral direita, tendo obtido a maior concentração de eixos $X$ no intervalo $N 30-68^{\circ} \mathrm{E} / \mathrm{S} 30-68^{\circ} \mathrm{W}$, a partir de uma população de dados numericamente superior e mais representativa.

Ciguel e Góis (1989), também considerando a bacia como preenchida por uma "seqüência molássica", descreveram-na como constituída por cunhas rudíticas que gradam e intercalam-se com ritmitos areno-pelíticos, em uma seqüência retrogradante depositada em um sistema de alta energia, águas rasas e correntes de turbidez (leques costeiros e aluviais, inunditos e lagos), com influência de tectônica sin-deposicional evidenciada pela ocorrência de discordâncias intra e extraformacionais.

Neiva e Tibinka (1989), Katbeh et al. (1989), Bissi Jr. et al. (1990), Liccardo et al. (1990) e Mendonça Filho et al. (1990) efetuaram mapeamentos parciais na região equivalente à Área Norte 
da Formação Camarinha, reconhecendo siltitos, conglomerados e arenitos depositados em leques aluviais de borda de escarpa de falha, adentrando corpos d'água na forma de correntes de turbidez. Os autores não reconheceram dobramentos nem metamorfismo nesta área de ocorrência da formação. Fiori (1990) também não reconheceu dobramentos em qualquer das áreas da Formação Camarinha. Posteriormente, Góis (1990) caracterizou as sucessões litológicas da Formação Camarinha como Sequiências de Bouma incompletas.

Ciguel et al. (1992) reconsideraram o ambiente de deposição da Formação Camarinha como sendo marinho, devido à descoberta de icnofósseis na porção noroeste da formação, tendo sido descritos exemplares de Gordia arcuata Ksiazkiewicz, Planolites montanus Richter, Skolithos Haldemann e cubicnia (traços de repouso de organismos medusóides como Cnidários). Com base nesses icnofósseis, posicionaram a formação entre o Vendiano e o Tommotiano.

Oliveira (1991) considerou a Formação Camarinha como tendo sido depositada em baixos estruturais gerados pela atividade da falha de Cubatão-Lancinha, a qual teria posteriormente sofrido reativações de caráter distensional no Paleozóico, afetando as rochas da Bacia do Paraná. Basei e Brito Neves (1992) propuseram uma tectônica de escape atuante ao longo de zonas de cisalhamento transcorrente reativadas como escoadouro dos movimentos convergentes durante o cessamento dos processos colisionais do Ciclo Brasiliano, com conseqüente formação de diversas bacias de pullapart, entre as quais estaria a bacia da Formação Camarinha.

Mais recentemente, mapeamentos efetuados na região a norte de Bateias por Wosniak e Feola (1997) e Santos e Fávaro (1997) consideraram parte das rochas aflorantes, anteriormente referidas como Seqüência Antinha, como pertencentes à Formação Camarinha, retomando assim a correlação anteriormente proposta por Soares (1987).

Finalmente, Basei et al. (1998) apontaram valores $\mathrm{K}-\mathrm{Ar}$ de $505 \pm 10 \mathrm{Ma}$ e $478 \pm 10 \mathrm{Ma} \mathrm{em}$ fração fina de siltitos da Formação Camarinha para um metamorfismo incipiente ocorrido nesses sedimentos.

\subsection{CONTEXTO GEOLÓGICO REGIONAL}

A bacia da Formação Camarinha foi inserida na transição Neoproterozóico-Eocambriano da faixa ou cinturão referido como Cinturão Ribeira por Almeida et al. (1973), Sistema Dobrado Apiaí por Hasui et al. (1975), e Região de Dobramentos Sudeste por Almeida et al. (1976) como sendo um "depósito molássico" relacionado ao final do Ciclo Brasiliano. O contexto regional da formação a seguir exposto pode ser visualizado na Fig. 2.1

Dentro da referida faixa ou cinturão, as unidades que constituem o embasamento da Formação Camarinha na região entre as localidades de São Luiz do Purunã, Bateias e Itambé são 


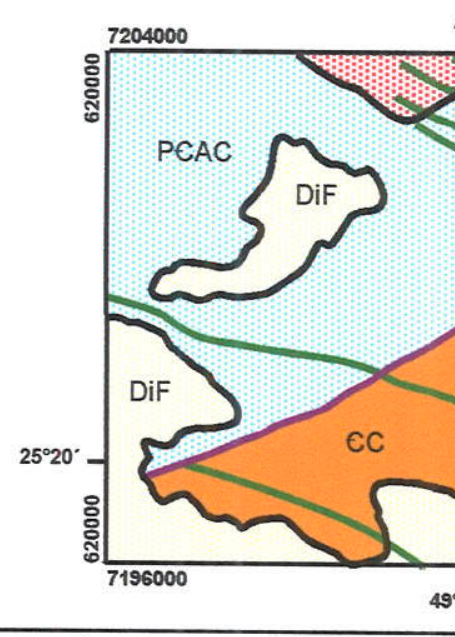

\begin{tabular}{|c|c|}
\hline & CONVENÇÕES \\
\hline $\mathrm{Ha}$ & HOLOCENO: Depósitos aluvionares \\
\hline$P G$ & PLEISTOCENO: Formaçāo Guabirotuba - argilitos, arenitos \\
\hline & JURÁSSICO-CRETÁCEO: Diques de diabảsio \\
\hline CF & PERMO-CARBONIFEERO: Grupo Itararé - arenitos, tilitos \\
\hline DiF & DEVONIANO INFERIOR: Formaçāo Furnas - arenitos e conglomerados \\
\hline$€ c$ & $\begin{array}{l}\text { TRANSICCĀO NEOPROTEROZÓICO - EOCAMBRIANO: } \\
\text { Formaçá Camarinha: conglomerados, arenitos feldspaaticos a liticos, siltitos, } \\
\text { lamitos, ritmitos, brechas intraformacionais }\end{array}$ \\
\hline 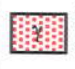 & $\begin{array}{l}\text { NEOPROTEROZÓICO: } \\
\text { Rochas graníticas: Passa Três (PT), Cerne (C), Três Córregos (TC) }\end{array}$ \\
\hline Be & 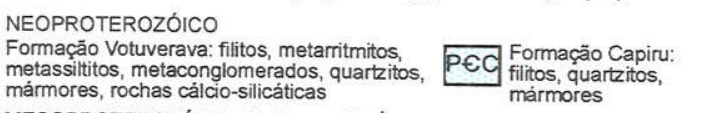 \\
\hline$\sqrt{P E A C}$ & $\begin{array}{l}\text { MESOPROTEROZÓIIC (?): Formaçäo Água Clara - mármores, metamargas, } \\
\text { flitos, xistos, quartzitos, metacherts, rochas metavulcánicas, metapeliticas e } \\
\text { metapsamiticas }\end{array}$ \\
\hline 祭 & $\begin{array}{l}\text { PALEOPROTEROZÓICO (?): Núcleo Betara - paragnaisses, xistos, quartzitos, } \\
\text { rochas metavulcănicas e metassedimentares terrigenas e clastoquimicas }\end{array}$ \\
\hline PaA & $\begin{array}{l}\text { PALEOPROTEROZÓICO: Complexo Atuba - rochas gnáissico-migmatiticas } \\
\text { e graniticas }\end{array}$ \\
\hline$\frac{1}{\sum_{x}^{2}}$ & $\begin{array}{l}\text { Contatos geológicos } \\
\text { Sinforme com caimento de eixo indicado } \\
\text { Fraturas e lineamentos } \\
\text { Falhas transcorrentes com indicação de movimento } \\
\text { Falhas de cavalgamento com indicaçōes de movimento } \\
\text { Lavra em atividade } \\
\text { Estradas }\end{array}$ \\
\hline
\end{tabular}

$49046^{\circ}$

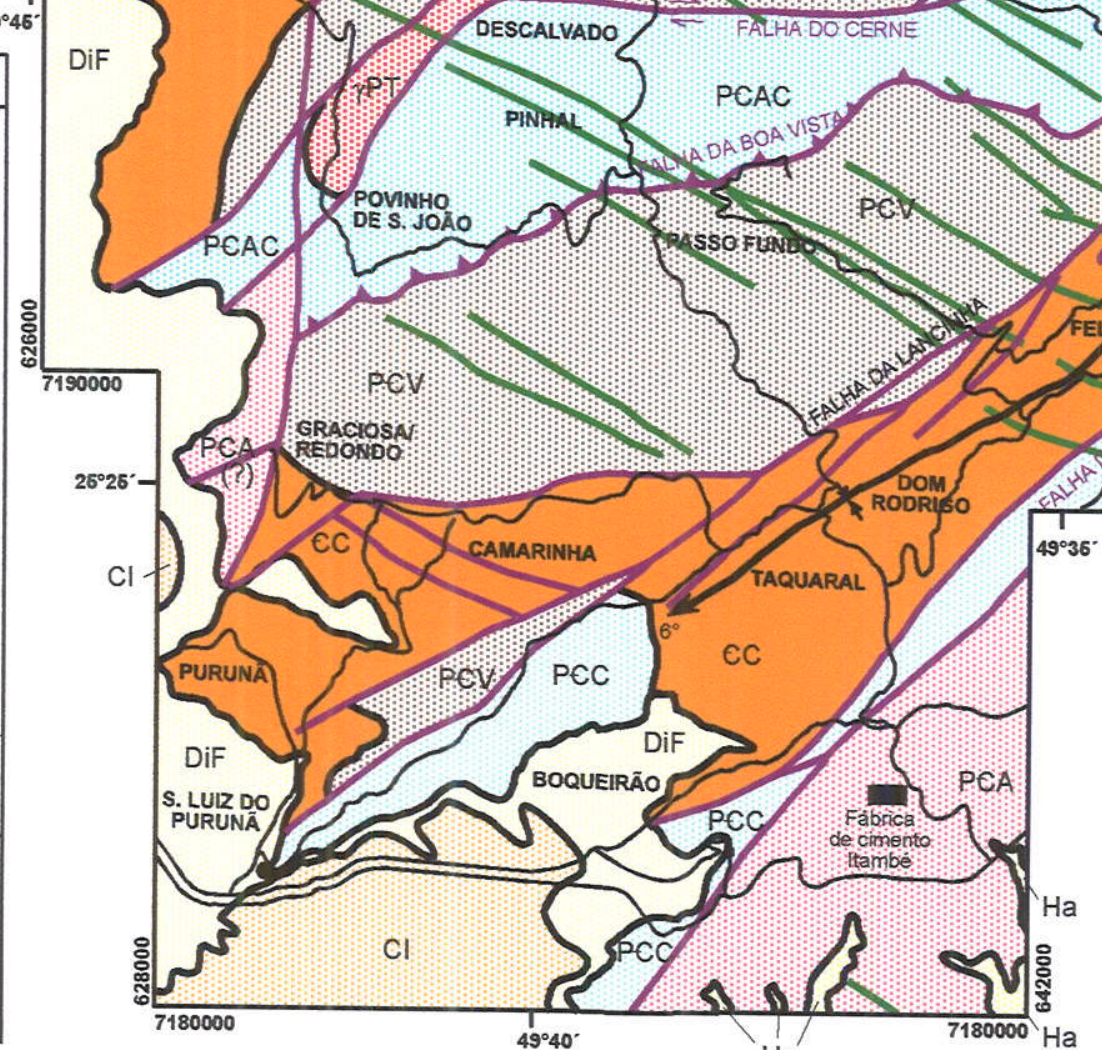

Fig.2.1: Contexto geológico regional da Formação Camarinha 
apresentadas na Fig.2.2 e no Mapa Geológico (Anexo I). Consistem em litotipos de idades paleoproterozóicas a neoproterozóicas, pertencentes ao Complexo Atuba, Núcleo Betara, formações Água Clara, Votuverava e Capiru, além de rochas graníticas diversas (granitos do Cerne e Passa Três, e Complexo Granítico Três Córregos).

A bacia da Formação Camarinha encontra-se separada dos metassedimentos mesoproterozóicos a neoproterozóicos das formações Água Clara, Capiru e Votuverava por discordância angular, e localmente por zonas de falhamentos transcorrentes de direção entre $\mathrm{N} 50^{\circ} \mathrm{E}$ e $\mathrm{N} 60^{\circ} \mathrm{E}$, associadas à Falha da Lancinha. A oeste, mostra-se recoberta em discordância angular pelos sedimentos devonianos (Assine, 1996) da Formação Furnas e permo-carboníferos do Grupo Itararé (Bacia do Paraná).

Sem estar em contato direto com a Formação Camarinha, porém ocorrendo muito próximas à mesma, verifica-se a existência de outras unidades pré-cambrianas na região. A sudeste da Área Sul, ocorrem rochas gnáissico-migmatíticas paleoproterozóicas do Complexo Atuba definido por Siga Jr. et al. (1995), e a nordeste da mesma área ocorrem rochas paleoproterozóicas a mesoproterozóicas do Núcleo Betara, bem como do Granito do Cerne (Neoproterozóico). A sudeste da Área Norte, verifica-se a ocorrência do Granito Passa Três, e a norte da mesma área observa-se a porção mais meridional do Complexo Granítico Três Córregos, ambos também considerados como do Neoproterozóico.

O conjunto dessas unidades pré-cambrianas que constituem o embasamento da bacia da Formação Camarinha encontra-se afetado por uma tectônica de cavalgamentos, dobramentos e transcorrências, além de cortado por diques cretáceos de diabásio com direções NW-SE. Localmente, o mesmo conjunto mostra-se recoberto de forma parcial a leste por sedimentos pleistocênicos da Formação Guabirotuba (Bacia de Curitiba) e depósitos aluvionares holocênicos.

As unidades do embasamento da Formação Camarinha serão brevemente descritas a seguir, acompanhadas por uma sintese de seu quadro estrutural regional. Essas unidades apresentam grande complexidade litológica e estrutural, tendo sido objeto de estudos os mais numerosos e diversos ao longo das últimas décadas. Tais estudos, embora tendo representado grandes contribuições ao entendimento da região, ainda não se mostraram conclusivos, razão pela qual na descrição a seguir será apresentada apenas uma síntese dos trabalhos que se revelaram os mais significativos, síntese esta também exposta no Quadro 2.1.

\subsubsection{Complexo Atuba (Paleoproterozóico)}

Ocorre na região sudeste da área estudada e possivelmente em outros núcleos a serem ainda devidamente caracterizados. Consiste em rochas anteriormente denominadas em caráter informal de 


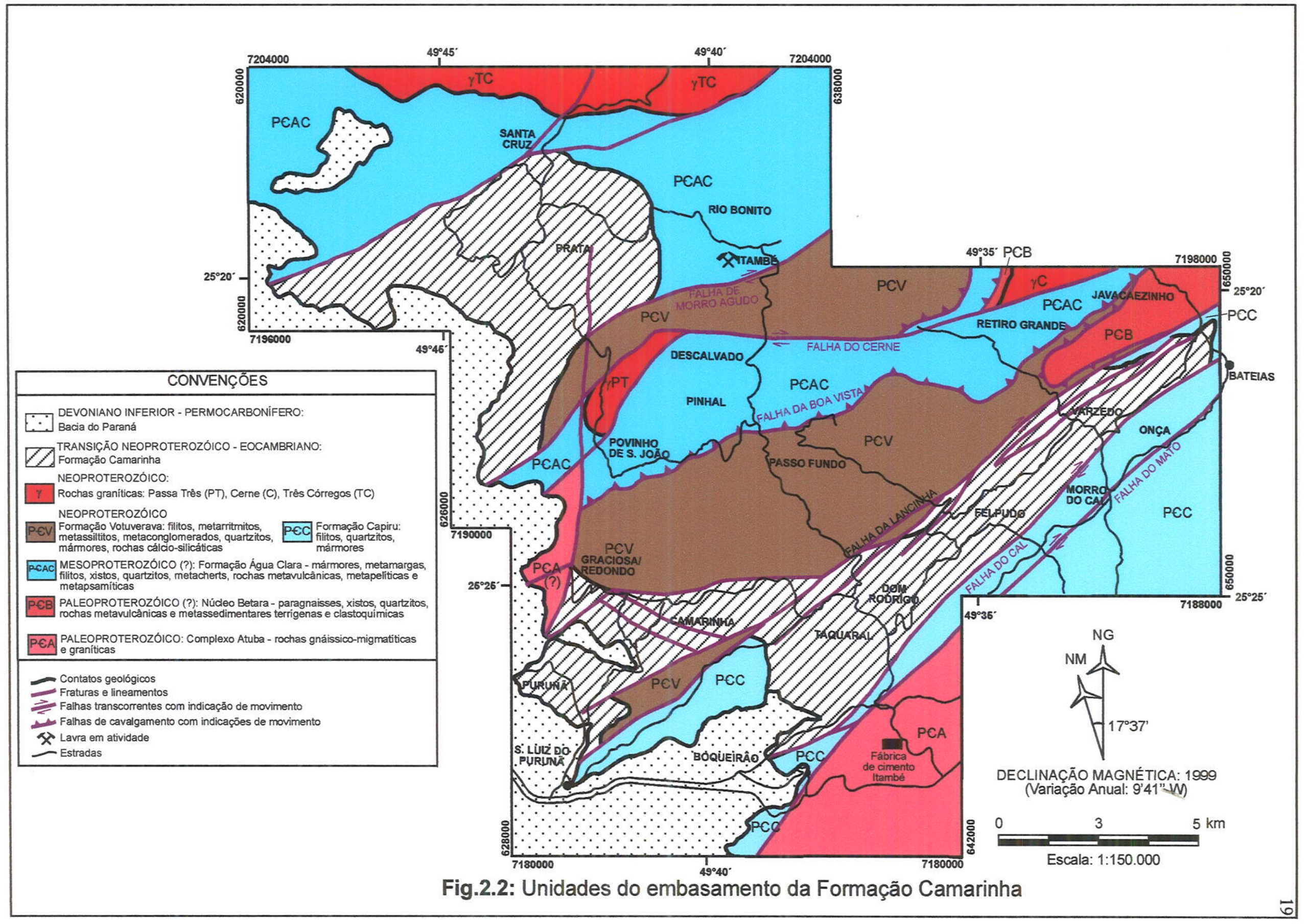




\begin{tabular}{|c|c|c|}
\hline IDADE & UNIDADE & DESCRIÇÃO \\
\hline Neoproterozóico & $\begin{array}{c}\text { Stocks e complexos graníticos } \\
\text { (Três Córregos, Cerne e } \\
\text { Passa Três) } \\
\end{array}$ & $\begin{array}{l}\text { Granitos e granito-gnaisses porfiríticos a } \\
\text { aplíticos sin a tardi-colisionais }\end{array}$ \\
\hline Neoproterozóico & $\begin{array}{l}\text { Formações Votuverava } \\
\text { e Capiru }\end{array}$ & $\begin{array}{c}\text { Filitos, quartzitos, mármores, metassiltitos, } \\
\text { metarritmitos, metaconglomerados e } \\
\text { rochas cálcio-silicáticas, afetadas por } \\
\text { cavalgamentos, dobramentos e } \\
\text { transcorrência }\end{array}$ \\
\hline Mesoproterozóico (?) & Formação Água Clara & $\begin{array}{c}\text { Metacalcários, mármores e metamargas } \\
\text { com intercalaçôes de filitos, xistos e } \\
\text { quartzitos, metapelitos, metapsamitos, } \\
\text { metacherts e rochas metavulcânicas, } \\
\text { afetadas por cavalgamentos, dobramentos e } \\
\text { transcorrência } \\
\end{array}$ \\
\hline Paleoproterozóico (?) & Núcleo Betara & $\begin{array}{c}\text { Rochas vulcânicas e metassedimentares } \\
\text { terrígenas e clastoquímicas, paragnaisses, } \\
\text { xistos, quartzitos e rochas granitóides, } \\
\text { afetadas por cavalgamentos, deformação } \\
\text { coaxial e transcorrência } \\
\end{array}$ \\
\hline Paleoproterozóico & Complexo Atuba & $\begin{array}{c}\text { Gnaisses migmatíticos, anfibolitos e xistos } \\
\text { magnesianos, rochas graníticas e gnáissico- } \\
\text { granulíticas, remigmatizadas e afetadas por } \\
\text { cisalhamento com componente lateral no } \\
\text { Neoproterozóico }\end{array}$ \\
\hline
\end{tabular}

Quadro 2.1: Síntese das unidades constituintes do embasamento da Formação Camarinha (Fontes: Fiori, 1990; Salamuni, 1991; Gimenez Filho, 1993; Reis Neto, 1994; Siga Jr. et al., 1995; Fassbinder, 1996; Basei et al., 1997; Harara et al., 1997; Hackspacher et al., 1999; Picanço e Tassinari, 1999; Prazeres Filho et al., em prep.)

"Complexo Cristalino" ou "Embasamento Gnáissico-Migmatítico", hoje pertencentes ao Domínio Curitiba, definido por Siga Jr. (1995) e limitado segundo este autor por zonas de cisalhamento emseus bordos NW e SE. Siga Jr. et al. (1995) descreveram para este complexo rochas de idade paleoproterozóica submetidas a uma remigmatização no Neoproterozóico, constituidas por gnaisses migmatíticos com intercalações de anfibolitos e xistos magnesianos, além de rochas graníticas e gnáissico-granulíticas. Estes autores detectaram uma foliação Sn paralela ao bandamento, a qual teria sido formada em regimes dúcteis associados a tectônica de cisalhamento com componente lateral durante o Neoproterozóico.

As idades obtidas pelos mesmos autores para a formação dos litotipos do Complexo Atuba situam-se no intervalo de 2.200-1.800 Ma (Rb-Sr) e em torno de 2.100 Ma (U-Pb), interpretadas como resultantes de migmatização e metamorfismo de fácies anfibolito a granulito no Ciclo Transamazônico. Foram também obtidas idades em torno de 580-620 Ma (Rb-Sr) e 560-600 Ma (KAr), interpretadas como resultantes de um reaquecimento com remigmatização no Brasiliano. 
Segundo os autores citados, esses terrenos teriam sido migmatizados, granitizados e acrescidos à borda do vizinho Domínio Luiz Alves (podendo também representar uma borda deformada do mesmo) durante o Neoproterozóico, em um processo de colisão e aglutinação de massas continentais persistente até o Cambro-ordoviciano e culminando na formação do Gondwana Ocidental. Posteriormente, os dados geocronológicos foram confirmados por Basei et al. (1997) e Harara et al. (1997).

\subsubsection{Núcleo Betara (Paleoproterozóico?)}

A extremidade sul deste núcleo ocorre na porção nordeste da região estudada, próximo à localidade de Bateias. Consiste em gnaisses, xistos, quartzitos, mármores, meta-argilitos, rochas metavulcânicas e granitóides expostas no núcleo de um anticlinal e inicialmente mapeadas como Formação Setuva da "Série Açungui" por Bigarella e Salamuni (1956) e por Marini et al. (1967). Posteriormente, a Formação Setuva foi elevada a Grupo por Popp et al. (1979), os quais definiram as formações Meia Lua (constituída pelos gnaisses) e Betara (constituídas por quartzitos e micaxistos) na região do Núcleo Betara. Piekarz (1984) incluiu parte das rochas do núcleo na Formação Perau (definida anteriormente por Fritzsons et al., 1982), e parte no chamado Complexo Pré-Setuva, termo cunhado por Schöll et al. (1982) para englobar as rochas gnáissicas e migmatíticas do embasamento da Formação Setuva a norte de Curitiba, com duas fases de migmatização sobrepostas.

Salamuni (1991) dividiu as rochas aflorantes no Núcleo Betara na Formação Betara, composta por rochas metavulcânicas e metassedimentares terrígenas e clastoquímicas, e no Complexo Meia Lua, constituído por paragnaisses, xistos, quartzitos e rochas granitóides na forma de uma imbricação tectônica. As duas formações estariam em contato uma com a outra por meio de uma falha de cavalgamento, mostrando metamorfismo até fácies anfibolito com retrometamorfismo à fácies xisto verde, e deformação dúctil-rúptil a rúptil-dúctil de baixo a alto ângulo, na forma de cavalgamentos, duplexes, deformação coaxial e transcorrência dentro de um sistema progressivo.

A idade do Núcleo Betara não se encontra ainda definida por meio de métodos geocronológicos, havendo dados U-Pb sendo atualmente tratados no Centro de Pesquisas Geocronológicas do IG-USP, indicando um valor inicial de 1.800-1.750 $\mathrm{Ma}$, dados estes que encontram-se em fase de refinamento para melhor definição (com. Verbal de Kaulfuss, $G$.).

\subsubsection{Formação Água Clara (Mesoproterozóico?)}

Ocorre na porção norte da área estudada, ao norte da Formação Votuverava e ao sul do Complexo Granítico Três Córregos. Consiste em metacalcários, mármores e metamargas com intercalações de filitos, xistos e quartzitos, além de metapelitos, metapsamitos, metacherts e rochas 
metavulcânicas descritos e caracterizados por diversos autores. Foi individualizada inicialmente no topo do Grupo Açungui por Marini et al. (1967), sobreposta à Formação Votuverava. Posteriormente, foi considerada contemporânea à Formação Votuverava por Marini (1970) e anterior à mesma por Pontes $(1981,1982)$, sendo então colocada na base do Grupo Açungui. Fritzsons et al. (1982), por sua vez, situaram a Formação Água Clara no topo do Grupo Setuva, atribuindo-the idade do Proterozóico Médio, enquanto Soares (1987) englobou os litotipos pertencentes à formação em um complexo denominado Complexo Água Clara-Perau-Setuva, constituído por seis associações litológicas depositadas em uma bacia de retro-arco ativa durante o final do Proterozóico Médio. Já Fiori (1990) considerou a Formação Água Clara uma unidade distinta, abaixo do Grupo Açungui, porém não necessariamente relacionada ao Grupo Setuva, o qual poderia representar uma tectonofácies do Complexo Pré-Setuva (originado por um processo de ductilização relacionado à Falha da Antiforma do Setuva).

Essas variações nas interpretações do posicionamento estratigráfico da Formação Água Clara devem-se principalmente à falta de dados geocronológicos precisos, baseando-se, segundo os diversos autores que a estudaram, em diferenças no grau metamórfico e no tipo e número de estruturas tectônicas superimpostas em seus tipos litológicos constituintes, comparativamente ao Grupo Açungui. Estas diferenças são atribuídas ora à atuação de diferentes ciclos tectônicos, ora a diferentes intensidades e profundidades de atuação de um mesmo ciclo tectônico, conforme os diferentes autores e modelos adotados. Com base em estudos de isótopos de ${ }^{18} \mathrm{O}$, Fassbinder (1996) sugere que a sedimentação da Formação Água Clara seria mais jovem que $1.3 \mathrm{Ga}$, valor este ainda não confirmado por análises geocronológicas. Assim, a idade mesoproterozóica é uma idade apenas estimada e relativa, necessitando de confirmação por meio de estudos geocronológicos mais aprofundados.

\subsubsection{Formações Votuverava e Capiru (Neoproterozóico)}

A Formação Votuverava ocorre entre as áreas Norte e Sul da bacia da Formação Camarinha, e a Formação Capiru a sudeste da Área Sul da mesma bacia. Os contatos dessas formações com a bacia da Formação Camarinha mostram-se ora discordantes, ora tectônicos, por meio de zonas de falhamentos transcorrentes representados pelas falhas da Lancinha e do Cal. As duas formações consistem em metassedimentos terrígenos e carbonáticos depositados em condições marinhas, desde plataforma carbonática rasa até taludes com depósitos turbidíticos. Esses metassedimentos seriam constituídos por filitos, quartzitos e mármores a sudeste da Falha da Lancinha (Formação Capiru), e filitos, metassiltitos, metarritmitos, metaconglomerados, quartzitos, mármores e rochas cálcio-silicáticas a noroeste da mesma Falha e ao sul da Falha de Morro Agudo (Formação Votuverava). As formações foram primeiramente definidas por Bigarella e Salamuni $(1956,1958)$ 
como parte, juntamente com a Formação Setuva, da "Série Açungui" originalmente definida por Oliveira (1927), tendo sido o empilhamento estratigráfico definido pela Formação Setuva na base, Formação Capiru na porção intermediária, e Formação Votuverava no topo. Posteriormente, a série passou a ser denominada de Grupo por Marini et al. (1967). Estes autores redefiniram, no mesmo trabalho, parte da Formação Votuverava original como Formação Água Clara no topo do grupo.

Trabalhos posteriores mantiveram a situação estratigráfica da Formação Capiru como abaixo da Formação Votuverava, com o posicionamento das demais unidades (Setuva e Água Clara) sendo continuamente revisto. Petri e Suguio (1969) e Ebert (1971a) foram os primeiros a sugerir uma contemporaneidade deposicional entre as formações Capiru e Votuverava, no que foram seguidos por outros autores.

Soares (1987) incluiu os litotipos constituintes das formações Capiru e Votuverava como parte de um complexo denominado Votuverava-Itaiacoca-Capiru, constituído por diversas associações litológicas depositadas em nova bacia de retro-arco superimposta à bacia na qual teria sido depositado o Complexo Água Clara-Perau-Setuva. Fiori (1990) considerou as formações Capiru e Votuverava como parte do Grupo Açungui, subdividindo-as em conjuntos litológicos distribuídos por blocos tectônicos individualizados por falhas de cavalgamento e transcorrência. Esses falhamentos teriam sido responsáveis por uma elevada aloctonia das unidades, colocando em contato lateral ou empilhando sucessões depositadas em áreas originalmente mais afastadas dentro de uma bacia de retro-arco.

Mais recentemente, Hackspacher et al. (1999) apresentaram dados U-Pb com resultados entre 615 e $619 \mathrm{Ma}$ para rochas metabásicas das regiões de Iporanga e Apiaí (SP), e de 608 Ma para o Granito Apiaí, ocorrendo estas rochas em estreita associação com o Grupo Açungui ou intrudidas no mesmo, levando os autores a considerarem a idade do referido grupo como muito próxima a estes valores.

\subsubsection{Seqüência Antinha (Neoproterozóico)}

Embora não aflore na região estudada, e sim mais ao norte da localidade de Bateias, propostas anteriores correlacionando a Seqüência Antinha à Formação Camarinha tornam necessária a inclusão neste trabalho de um breve histórico dos estudos efetuados sobre a mesma.

Parte da Formação Votuverava a nordeste da região estudada foi redefinida como Seqüência Antinha por Pontes (1981), sendo constituída por metarritmitos sílticos a arenosos com níveis areno-conglomeráticos intercalados, com menor grau metamórfico e menor complexidade deformacional que a Formação Votuverava propriamente dita. Dias e Salazar Jr. (1987) incluíram na Seqüência Antinha metacalcários e metarritmitos arenosos com intercalações de metaconglomerados e metassiltitos, mantendo a seqüência no topo do Grupo Açungui. Estes autores 
verificaram ainda a ocorrência de dobramentos com eixos horizontais e metamorfismo termal associado ao Complexo Granítico Três Córregos nas rochas da Seqüência Antinha.

Soares (1987) considerou a Seqüência Antinha como constituída apenas pelas unidades metassedimentares anteriormente definidas por Pontes (1981), correlacionando-a à Formação Camarinha na forma de uma sequiência terrigena depositada em uma bacia tardicolisional de foreland de retro-arco. Esta correlação foi mantida em alguns trabalhos de cartografia geológica na região, efetuados por Wosniak e Feola (1997) e Santos e Fávaro (1997), que denominaram de Formação Camarinha as ocorrências da Seqüência Antinha na região. Já Fiori (1990) definiu a Seqüência Antinha como uma formação pertencente ao Grupo Açungui.

Kops (1994) considerou a Formação Antinha uma sucessão contemporânea à Formação Votuverava, ambas depositadas em sub-bacias marinhas possivelmente de retro-arco. $\mathrm{O}$ mesmo autor caracterizou três eventos de deformação atuantes na Formação Antinha (cavalgamentos, dobramentos e transcorrência), com geração de foliações e três fases de metamorfismo correspondentes, incluindo o metamorfismo termal associado ao Complexo Granítico Três Córregos. Embora estas feiçôes de deformação e metamorfismo sejam relativamente pouco intensas na Formação Antinha comparativamente às formações Água Clara e Votuverava que ocorrem na região, sua ocorrência invalida as propostas de correlação com a Formação Camarinha, visto que esta última apresentamse deformada apenas pelos eventos de transcorrência e sem metamorfismo visível.

\subsubsection{Rochas graníticas (Neoproterozóico)}

Nas regiões norte e leste da área estudada, afloram os extremos sul, respectivamente, do Complexo Granítico Três Córregos e do Granito do Cerne, enquanto na região centro-oeste aflora o Granito Passa Três.

O Granito Três Córregos foi cartografado por Muratori et al. (1965) e Fuck et al. (1965) nas folhas geológicas de Campo Largo e Quero-Quero, elaboradas pela Comissão da Carta Geológica do Paraná, tendo sido descrito nas correspondentes notas explicativas elaboradas por Muratori (1966) e Fuck (1966) como constituído por rochas predominantemente porfiríticas. Estas rochas foram descritas por Fuck et al. (1967a) como granitos e quartzo-monzonitos na forma de um batólito intrusivo nos metassedimentos proterozóicos, tendo portanto caráter tardi a pós-tectônico. Soares (1988) considerou essas rochas como parte de um complexo sin-colisional de idade entre 640-800 Ma, intrudidas no ambiente do arco magmático.

Gimenez Filho (1993) definiu diversos corpos graníticos orientados e de anatexia para o Complexo Granítico Três Córregos no sul e sudeste do Estado de São Paulo. Este autor caracterizou o complexo como uma seqüência cálcio-alcalina básica-intermediária-ácida de granitóides do Tipo 
I, tardi a pós-colisionais, compatíveis com ambiente de raiz de arco magmático do tipo Andino. $\mathrm{O}$ mesmo autor obteve, para diversos corpos datados, idades $\mathrm{Rb}-\mathrm{Sr}$ variando entre 800 e $650 \mathrm{Ma}$ para a formação de cada corpo em questão, e idades K-Ar variando entre 600-625 Ma, interpretadas como resultantes do resfriamento relacionado à estabilização do final do Ciclo Brasiliano. $O$ autor caracterizou ainda uma suíte pós-tectônica de granitos crustais do Tipo A naquela região, de idades variando entre 480-520 $\mathrm{Ma}(\mathrm{Rb}-\mathrm{Sr})$.

Reis Neto (1994) citou descrições de rochas porfiriticas, aplíticas e granito-gnaisses de composição variada como constituindo fácies do Complexo Três Córregos, o qual teria quimismo cálcio-alcalino, idades entre 600-700 Ma e constituiria a raiz de um arco magmático de idades em torno de $660 \mathrm{Ma}(\mathrm{Rb}-\mathrm{Sr})$ e $778 \mathrm{Ma}(\mathrm{Pb}-\mathrm{Pb})$. Este autor verificou que os granito-gnaisses têm a mesma filiação geoquímica dos granitos, constituindo provavelmente fácies milonitizadas dos mesmos. O mesmo autor também caracterizou uma suíte mais recente na região de Três Córregos (PR), com idades Rb-Sr em torno de $510 \mathrm{Ma}$.

Mais recentemente, Prazeres Filho et al. (em prep.) obtiveram idades U-Pb de 599 e $604 \mathrm{Ma}$ para o complexo.

O Granito do Cerne foi assim denominado e descrito por Muratori (1966) como uma rocha de granulação média intrusiva no núcleo de um anticlinal a noroeste da localidade de Bateias, com formato elíptico de direção NE-SW e nítido caráter intrusivo nos metassedimentos, evidenciado pela presença de auréolas de metamorfísmo de contato, xenólitos e restos de teto. Com base nesses critérios, Fuck et al. (1967a) considerarammno tardi a pós-tectônico. Fiori (1984) o descreveu como de composição álcali-quartzo sienítica e quartzo-sienítica a granítica, e Fiori (1985d, 1990) consideroumo contemporâneo aos falhamentos transcorrentes, por encontrar-se alojado em um núcleo de anticlinal escalonado pertencente ao sistema da Falha da Lancinha, fenômeno este observado em outros corpos graníticos do Pré-Cambriano paranaense, como os granitos Piedade, Morro Grande e Varginha. Por fim, Soares (1988) considerou o Granito do Cerne como parte de um complexo tardi-tectônico formado no ambiente de retro-arco.

O Granito Passa Três, de composição sieno-granítica e granulação média a grossa, foi primeiramente descrito por Piekarz (1980). Soares e Góis (1987) descreveram-no como um stock com contatos em parte tectônicos e em parte intrusivos com as formações Água Clara e Votuverava. Soares (1988) também considerou-o parte de um complexo tardi-tectônico intrudido no ambiente de retro-arco, juntamente com o Granito do Cerne. Piekarz et al. (1991) descreveram-no como um quartzo-sienito de natureza metaluminosa e derivação mantélica com contaminação crustal, com granulação fina a localmente porfiritica e diques aplíticos, colocado e deformado sob condições rúpteis-dúcteis associadas a zonas de cisalhamento transcorrente. Mais recentemente, Picanço e 
Tassinari (1999) obtiveram idades $\mathrm{Rb}$-Sr em torno de $527 \mathrm{Ma}$ para o Granito Passa Três, presumindo uma composição cálcio-alcalina enriquecida em potássio para o mesmo.

\subsubsection{Quadro Estrutural Regional}

Carvalho e Pinto (1937) já haviam detectado a presença de anticlinais e sinclinais afetando as rochas metassedimentares do Pré-Cambriano paranaense, e Maack (1947) atribuiu essas dobras a duas fases distintas de dobramentos. Este autor verificou também a ocorrência de uma grande falha de direção $\mathrm{N} 40^{\circ} \mathrm{E}$, à qual associam-se outras falhas que Marini (1970) descreveu como estruturas direcionais inversas de alto ângulo, com formação de estrutura em escama. A falha detectada por Maack (1947) viria a ser denominada Falha da Lancinha por Fuck et al. (1971). Ebert (1971a) foi o primeiro a supor a ocorrência de uma tectônica de nappes e cavalgamentos na região.

Diversos autores que se seguiram passaram a procurar estabelecer um número de fases de deformação para a região, os quais variariam desde dois a até quatro. Outros autores, a partir de Batolla Jr. et al. (1977) e Paiva et al. (1977), reconheceram um deslocamento lateral direito para a movimentação principal da Falha da Lancinha.

Fiori $(1984,1985 a, b, c, 1990)$ e Fiori et al. $(1987 a, b, c)$ foram os primeiros a analisar de modo sistemático e integrado os sistemas de lineamentos, dobramentos e estruturas associadas na região. Caracterizaram um sistema de cavalgamentos como o primeiro evento a deformar as rochas do Grupo Açungui, seguido por um sistema de dobramentos abertos, e posteriormente por um evento de transcorrência representado pelas falhas da Lancinha e Morro Agudo (ambas com deslocamento lateral direito mínimo respectivamente de 114 e $106 \mathrm{~km}$ ) e estruturas associadas.

O sistema de cavalgamentos foi denominado por Fiori (1990) de Sistema de Cavalgamentos Açungui. Segundo este autor, este evento teria sido responsável por elevada aloctonia, fatiamento e empilhamento tectônico das unidades, alterando significativamente a estratigrafia original. Este sistema seria caracterizado por truncamento de camadas, geração de foliação $\mathrm{Sc}$ (ou $\mathrm{S}_{1}$ ) de baixo ângulo paralela ou subparalela ao acamamento So original, foliações secundárias associadas, transposições, dobras-falhas e estiramento mineral. Essas estruturas configurariam um arranjo em duplex, refletindo os efeitos de uma colisão continente-arco-continente.

O sistema de dobramentos foi denominado por Fiori (1990) de Sistema de Dobramentos Apiaí, seguindo a denominação proposta por Hasui et al. (1975) para toda a faixa ou cinturão onde a Formação Camarinha encontra-se inserida, sendo caracterizado pelo dobramento de $S_{0}$ e $S_{1}$ e pela geração de sinformes e antiformes, tanto em escala de afloramento como em escala regional, apresentando planos axiais subverticais com foliação plano-axial incipiente associada, eixos de direção NE e caimentos geralmente suaves para SW. 
O mesmo autor denominou o sistema transcorrente de Sistema de Transcorrência Lancinha, constituido pelas falhas da Lancinha, Morro Agudo e associadas, tais como as falhas do Cerne, do Cal, do Mato, de Itaqui e outras. Segundo o autor, o sistema transcorrente afetaria as estruturas geradas nos eventos anteriores, sendo caracterizado por feições rúpteis como fraturamento de rochas, aspecto anastomosado e contorcido, dobras escalonadas e estruturas de arrasto sigmoidais indicativas de movimentação lateral direita, lenticularização de camadas, estiramento de seixos da Formação Camarinha e planos de foliação cataclástica com mergulhos altos a verticais e estrias de atrito sub-horizontais. Intrusões graníticas como as do Cerne, Piedade, Morro Grande e Varginha alojaram-se nos núcleos de dobras escalonadas associadas, sofrendo deformações dúcteis e posteriormente rúpteis. De acordo com Fassbinder (1990), esses granitos teriam idades estimadas em torno de $550 \mathrm{Ma}$, tendo sido intrudidos penecontemporaneamente à transcorrência.

Fassbinder (1990) e Fassbinder et al. (1994) descreveram estruturas associadas à Falha da Lancinha compatíveis com o Modelo de Riedel, atribuindo-lhe caráter transpressivo rúptil-dúctil a rúptil e deslocamento lateral direito mínimo de $130 \mathrm{~km}$ como movimento principal. Com base no caráter transpressivo e em feições diversas de caráter inverso relacionadas à falha, Fassbinder (1990) sugeriu a ocorrência de estrutura em flor positiva em forma de meia-taça associada à Falha da Lancinha, com mergulhos de alto ângulo para noroeste.

Segundo Fiori (1985a, 1990) e Fassbinder (1990), a Falha da Lancinha seria o reflexo em superficie de uma falha anterior mais profunda, representada pelo Lineamento AlémParaíba/Cubatão, na forma de uma reativação em condições rúpteis-dúcteis deste último.

Reativações posteriores do sistema da Falha da Lancinha foram identifícadas e descritas por diversos autores, como Fiori (1985b, 1990), Moritz Jr. e Fiori (1987), Soares (1987, 1988), Soares e Góis (1987), Zalán et al. (1987), Fassbinder (1990) e Oliveira (1991). Para Soares (1987, 1988), e Soares e Góis (1987), esta reativação teria caráter distensivo e deslocamento lateral esquerdo já na fase pós-colisional ao início do Paleozóico, tendo sido responsável pela abertura de bacias transtensionais como a de Castro, e deformação e hidrotermalismo do Granito Passa Três. Fassbinder (1990) descreveu este movimento como formador de macro-lentes tectônicas evidenciadas em imagens de satélite. Já Fiori (1985b, 1990), Moritz Jr. e Fiori (1987) e Fassbinder (1990) detectaram uma reativação mesozóica lateral esquerda para o sistema da Falha da Lancinha, por meio da observação de deslocamentos de diques de diabásio e deformação sofrida por seixos em rochas da Formação Camarinha, com deslocamento calculado entre 800 e $1000 \mathrm{~m}$. Fiori (1985b) considerou a possibilidade de os últimos $950 \mathrm{~m}$ de deslocamento lateral esquerdo da Falha da Lancinha no Mesozóico terem ocorrido ao final de um movimento sinistral maior e iniciado já no Cambro-Ordoviciano, mencionado e descrito por Schöll (1981) como tendo um deslocamento de 20-30 km. Posteriormente, entretanto, Fiori (1990) rejeitou as proposições de Schöll (1981). 
Zalán et al. (1987) e Oliveira (1991) registraram reativações diversas ao longo do Paleozóico, com caráter predominantemente distensivo manifestado na forma de falhas normais lístricas e subverticais, gerando baixos estruturais que interferiram na deposição de diversas unidades da Bacia do Paraná. No Mesozóico, estes autores verificaram leves componentes horizontais laterais esquerdos associados às reativações de modo subordinado.

Mais recentemente, Fassbinder (1996) propôs uma evolução tectônica para a região como relacionada a uma tectônica de transpressão oblíqua, com partição da deformação entre cavalgamentos e transcorrências, gerando uma estrutura em flor positiva com alçamento simétrico das unidades do Pré-Cambriano paranaense em torno dos complexos graníticos, os quais ocupariam a região central da estrutura para a qual convergiriam os mergulhos das demais unidades. Tal modelo, pela sua natureza recente, deverá ainda ser melhor estudado para uma eventual confirmação.

\subsection{BACIAS E OCORRÊNCIAS DA TRANSICÃ̃O NEOPROTEROZÓICO-EOCAMBRIANO DO SUL E SUDESTE DO BRASIL}

Bacias e ocorrências semelhantes à da Formação Camarinha, tanto em idade como em preenchimento sedimentar, ocorrem nos estados de Minas Gerais (Pouso Alegre), São Paulo (Eleutério, Pico de Itapeva e outras ocorrências menores, como Quatis, Samambaia, Cajamar, Salto de Pirapora e Pirapora do Bom Jesus), Paraná (Castro, Ervalzinho e Guaratubinha), Santa Catarina (Itajaí, Campo Alegre e Corupá) e Rio Grande do Sul (Camaquã e Guaritas) (Fig.2.3). Essas bacias ocorrem associadas aos cinturões Ribeira e Dom Feliciano, e aos crátons Luiz Alves e Rio de la Plata, sendo ocorrências de extensões e graus de conhecimento variados, frequientemente interpretadas por seus pesquisadores como associadas a zonas de transcorrência atuantes na transição Neoproterozóico-Eopaleozóico, com ou sem vulcanismo associado. Diversas tentativas de correlação entre as mesmas vêm sendo feitas, sendo aqui apresentado um breve histórico sobre o conhecimento de cada uma a fim de se discutir posteriormente as correlações já propostas.

\subsubsection{Eleutério e Pouso Alegre}

Ebert $(1968,1971 b)$ foi o primeiro a identificar os folhelhos, siltitos, arcóseos e arcóseos conglomeráticos não metamorfisados associados à zona de falha Itapira-Jacutinga-Ipuiuna no nordeste do estado de São Paulo, propondo as denominação de Grupo Eleutério para os mesmos e atribuindo-lhes idade equivalente à das rochas do Grupo Itajaí (SC). Dentro do mesmo cinturão de cisalhamento, porém na região a noroeste da cidade de Pouso Alegre (sudeste do estado de Minas 


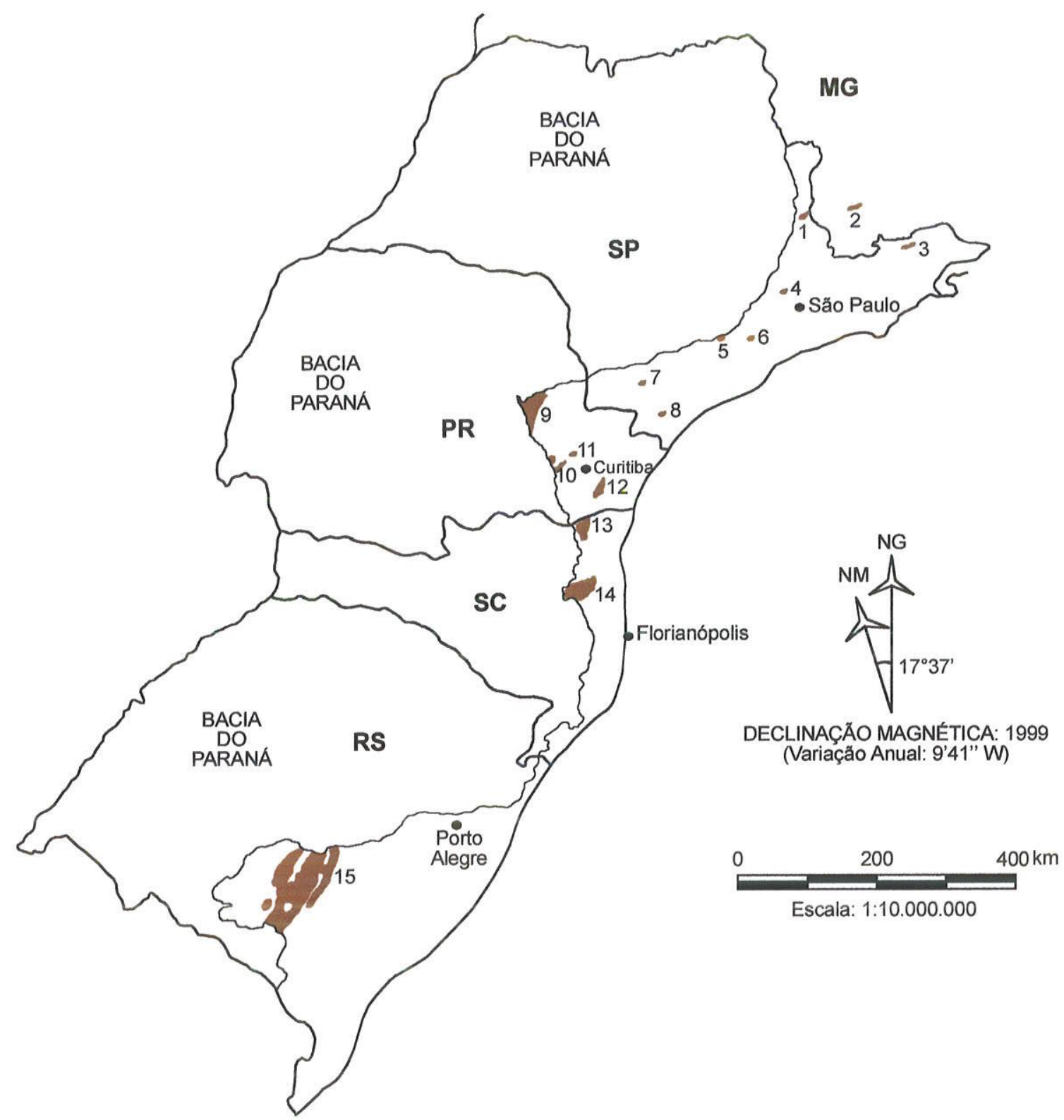

Fig.2.3: Bacias e ocorrências de sedimentos da transição

Neoproterozóico-Eocambriano no Sul e Sudeste do Brasil, sendo:
1 - Eleutério
2 - Pouso Alegre
3 - Pico de Itapeva
4 - Cajamar *
5 - Salto de Pirapora
6 - Pirapora do Bom Jesus
7 - Samambaia
8 - Quatis
9 - Castro
10 - Camarinha
11 - Ervalzinho
12 - Guaratubinha
13 - CampoAlegre/Corupá
14 - Itajaí **
15 - Camaquã/Guaritas

Fonte: Reduzido e simplificado de Schobbenhaus et al. (1981)

* Em subsuperfície e com predomínio de sedimentação carbonática

** Predomínio de sedimentação de águas profundas 
Gerais), Leonardos Jr. et al. (1971) descreveram sedimentos semelhantes, denominando-os Formação Pouso Alegre e correlacionando-os aos do Grupo Eleutério.

Hama e Cunha (1977) obtiveram valores de idade K-Ar mínima de $485 \pm 20$ Ma e $524 \pm 20$ Ma para um metamorfismo de baixo grau dos sedimentos da Formação Pouso Alegre, rejuvenescidos isotopicamente pelos últimos eventos de deslocamento e aquecimento sofridos pela unidade. Fiori et al. (1978) consideraram os depósitos de ambas as formações como resultado das manifestações finais do Ciclo Brasiliano, sendo depositados em ambientes de planície de inundação, deltaicos e fluviais em bacia condicionada tectonicamente. Essas características e interpretações a respeito das bacias de Eleutério e Pouso Alegre foram mantidas e eventualmente detalhadas por diversos autores que se seguiram.

Teixeira e Petri (1993) propuseram idade eopaleozóica e natureza de pull-apart para a Bacia de Eleutério, com origem a partir de movimentos sinistrais ao longo da Zona Transcorrente de Jacutinga. Segundo os autores, o preenchimento ter-se-ia dado inicialmente de NNW para SSE, e posteriormente de SSE, a partir de fontes com clima árido sujeito a chuvas torrenciais. As fácies sedimentares identificadas foram de natureza lacustre, e proximais, medianas e distais de leques aluviais. A clivagem ardosiana e o basculamento de camadas teriam sido originados por encurtamento da bacia devido à inversão do deslocamento da zona de cisalhamento de sinistral para dextral.

Essas proposições foram mantidas por Teixeira (1996), que considerou as bacias de Eleutério e Pouso Alegre partes de uma bacia originalmente maior, separadas por ocasião da compressão proporcionada pela inversão no movimento da zona de cisalhamento. $O$ autor sugereainda uma similaridade genética entre as bacias de Eleutério e Pouso Alegre com as bacias do Pico de Itapeva, Quatis, Samambaia e Salto de Pirapora, as quais teriam evoluído contemporaneamente durante o intervalo Proterozóico Superior-Cambriano, geradas entre 600 530 Ma ao longo do Cinturão Ribeira. Para o autor, o interior do cinturão poderia estar ocupado por uma área oceânica restrita, do tipo golfo, ao longo da qual dar-se-ia o preenchimento dessas bacias com fácies desde continentais até transicionais e marinhas rasas. Não foram detectadas ocorrências vulcânicas, com exceção de seixos riolíticos anquimetamórficos presentes em fácies conglomeráticas, originados possivelmente de um edifício vulcânico supostamente mais antigo e exumado pela erosão.

\subsubsection{Pico de Itapeva e outras ocorrências menores no Estado de São Paulo}

Os metassedimentos do Pico de Itapeva (SP) foram primeiramente descritos por Almeida (1964) e denominados Formação Pico de Itapeva por Cavalcante et al. (1971). Esses autores identificaram metaconglomerados, metarenitos feldspáticos e metassiltitos, correlacionando-os às 
bacias de Eleutério e Pouso Alegre. Posteriormente, Juliani et al. (1990) colocaram essas rochas dentro de uma estrutura sinclinal isoclinal com contatos tectônicos, atribuindo a deposição a fluxos de detritos subaéreos retrabalhados em ambiente costeiro dominado por ondas, inclusive de tempestades, caracterizadas por estruturas hummocky.

Riccomini (1993) caracterizou a Bacia do Pico de Itapeva como uma bacia de pull-apart relacionada a uma movimentação sinistral ao longo da Zona de Cisalhamento de Jundiuvira, posteriormente submetida a uma inversão dextral que promoveu encurtamento e conseqüente deformação dos sedimentos constituintes. O transporte tectônico teria ocorrido de SE para NW, de acordo com lineações minerais e falhas reversas presentes. A deformação sofrida seria responsável por um metamorfismo de baixo grau, com dobramentos e geração de foliação plano-axial associada. O autor atribuiu idade neoproterozóica-eopaleozóica à bacia.

Outras ocorrências restritas de sedimentos atribuídos ao Eopaleozóico foram detectadas em diversos pontos do estado de São Paulo, como nas regiões de Salto de Pirapora e Pirapora do Bom Jesus (Hasui et al., 1982), Cajati (Formação Quatis de Campanha e Teixeira, 1986), metassedimentos Samambaia (Petri e Suguio, 1969) e Cajamar (Hachiro e Santoro, 1996). As ocorrências de Salto de Pirapora e Pirapora do Bom Jesus foram descritas por Hasui et al. (1982) como conglomerados polimíticos, arenitos arcosianos e arenitos finos embutidos por falhas no Grupo São Roque e correlacionáveis aos depósitos das bacias de Eleutério e Pouso Alegre. A Formação Quatis consiste em sedimentos imaturos e anquimetamórficos como metarcóseos, metarenitos, metargilitos, metassiltitos e metaconglomerados descritos por Campanha e Teixeira (1986), que os correlacionaram à Formação Camarinha e ao Grupo Castro. Os metassedimentos Samambaia consistem em metaconglomerados e metarenitos gradacionais e imaturos definidos por Petri e Suguio (1969) como possuindo características de "molassa pós-orogenética". Já a ocorrência de Cajamar é bastante distinta das demais, tendo sido reconstituída a partir de testemunhos de sondagens por Hachiro e Santoro (1996) e possuindo composição essencialmente carbonática, na forma de cálcio-arenitos e conglomerados com clastos fosfáticos e carbonáticos pouco deformados e de baixo grau metamórfico, depositados em ambiente plataformal raso ou planícies de marés.

\subsubsection{Castro}

Derby (1878) descreveu as rochas de região de Castro (centro-leste do estado do Paraná) como "porphyros vermelhos" metamórficos associados a arcóseos, posteriormente reclassificados por Leinz (1936) como quartzo-pórfiros de origem efusiva. Essas rochas foram colocadas por Woodworth (1916) entre a então chamada "Série São Roque" (SP) e o Devoniano, juntamente com brechas felsíticas e arenitos não metamorfisados. Oliveira (1927) incluiu-as na "Série Açungui", e 
Oliveira e Leonardos (1943) transferiram-nas para a "Série Ribeira" com o nome de Formação Castro, a qual foi posteriormente elevada a Grupo por Trein e Fuck (1967).

A descoberta de seixos de composição andesítica em conglomerados do Grupo Castro levou Moro (1993) e Moro et al. (1993) a proporem um empilhamento estratigráfico deste grupo, na forma de quatro associações litológicas, assim definidas da base para o topo: Vulcânica Intermediária-Ácida, constituída por rochas vulcânicas e piroclásticas intermediárias e ácidas intercaladas, além de conglomerados subordinadamente; Sedimentar Inferior, constituída por arenitos arcosianos, siltitos e lamitos de planícies de inundação, preenchimento de canais e lagos; Vulcânica Ácida, constituída por domos riolíticos, quartzo latitos, brechas piroclásticas e tufos; e Sedimentar Superior, constituída por conglomerados de leques aluviais. Estas associações foram denominadas, respectivamente, Associação Tronco, Associação Piraí do Sul e Associação Tirania (esta última correspondendo às associações Vulcânica Intermediária-Ácida e Sedimentar Superior) por Moro et al. (1994).

Moro (1993) obteve isócronas Rb-Sr nos valores de 488.3 \pm 7.9 Ma e 466.6 \pm 7.7 Ma para riolitos da Associação Vulcânica Ácida e efetuou análises litoquímicas das rochas vulcânicas, sugerindo uma fonte comum para os riolitos e andesitos. A mesma autora considerou a Bacia de Castro uma bacia molássica intermontana, com origem transtensional relacionada a uma movimentação lateral direita da falha que delimita sua borda leste. Esta falha, caracterizada como uma antitética com rejeito oblíquo do Sistema de Transcorrência Lancinha (reativado com movimentação lateral esquerda no Cambro-Ordoviciano), foi denominada Falha de Castro por Bonacim et al. (1994).

Mais recentemente, datações U-Pb (SHRIMP) foram efetuados em riolitos da Bacia de Castro por Cordani et al. (1999), fornecendo idades de $543 \pm 12 \mathrm{Ma}$.

\subsubsection{Ervalzinho}

Pontes (1981), ao estudar a Seqüência Antinha no Estado do Paraná, detectou na mesma região um conjunto de rochas conglomeráticas e arcosianas posteriormente denominada Unidade Conglomerática Arcosiana por Dias e Salazar Jr. (1987), que a consideraram correlacionável à Formação Camarinha. Segundo estes autores, essa unidade estaria em posição discordante em relação à Seqüência Antinha, sendo constituída por conglomerados polimíticos com matriz arcosiana e intercalações de arenitos arcosianos grossos, imaturos textural e mineralogicamente. Segundo os mesmos autores, essas rochas teriam sido depositadas em ambiente subaéreo, por meio de cones de dejeção com contribuição fluvial, ao longo de uma escarpa de falha.

Kops (1994) denominou a Unidade Conglomerática Arcosiana de Formação Ervalzinho, considerando-a como depositada em uma bacia de strike-slip pós-colisional, por não apresentar 
feições de deformação por cavalgamentos ou dobramentos, tampouco características de metamorfismo, e sim apenas um fraturamento gerado por cisalhamento rúptil .

\subsubsection{Guaratubinha}

Fuck et al. (1967b) cartografaram e descreveram as rochas vulcânicas e sedimentares a sudeste do município de São José dos Pinhais (leste do estado do Paraná), denominando-as Formação Guaratubinha. Os autores dividiram a formação em três seqüências: sedimentar, constituída por arcóseos, siltitos, argilitos e conglomerados; riolítica, constituída por riolitos e rochas piroclásticas como tufos, brechas e aglomerados; e andesítica, constituída por andesitos e dacitos. Segundo os autores, a formação estaria assentada discordantemente sobre seu embasamento, apresentando-se ligeiramente metamorfisada, basculada em blocos e brechada. Os mesmos autores correlacionaram a Formação Guaratubinha aos grupos Castro e Itajaí, considerando-a como de idade eopaleozóica, depositada em fossas tectônicas.

Posteriormente, Ebert (1971c) correlacionou as rochas da Formação Guaratubinha às rochas vulcânicas da região de Campo Alegre (SC), denominando o conjunto de Grupo Guaratubinha. Daitx e Carvalho (1981) detalharam os estudos sobre a formação, seguidos por Soares (1987, 1988), o qual correlacionou as rochas da Formação Guaratubinha e do Grupo Castro, interpretando-as como depositadas em bacias molássicas tardias ou pós-colisionais, relacionadas a falhamentos.

Mais recentemente, Castro (1993) definiu cinco associações litológicas para a Bacia de Guaratubinha, com predomínio de rochas vulcânicas e vulcanoclásticas ácidas a intermediárias, e conglomerados polimíticos subordinadamente. Este autor caracterizou também uma cogeneticidade entre os vulcanismos ácido e intermediário, a partir de análises de elementos maiores, traços e Terras-Raras, revelando quimismo semelhante ao das rochas vulcânicas do Grupo Castro.

Siga Jr. et al. (1999) obtiveram idades de $570 \pm 10$ Ma pelo método Rb-Sr e de $628 \pm 28$ pelo método U-Pb para riolitos da Formação Guaratubinha, enquanto Basei et al. (1998) apresentaram idades de 604.6 \pm 8.6 Ma, também para riolitos da mesma formação.

\subsubsection{Campo Alegre-Corupá}

Almeida (1949) registrou a ocorrência de rochas vulcânicas e piroclásticas na região de Campo Alegre (nordeste do estado de Santa Catarina), atribuindo-lhes idade eopaleozóica por comparação a riolitos porfiriticos da Bacia de Itajaí. Albuquerque et al. (1971) denominaram a unidade de Formação Campo Alegre e incluíram-na no Grupo Itajá, juntamente com a Formação Baú, constituída por conglomerados. Entretanto, Ebert (1971c), subdividindo as rochas da Bacia de Campo Alegre em três formações, considerou-as mais recentes que as da Bacia de Itajaí, denominando-as Grupo Guaratubinha e correlacionando-as ao Grupo Castro e à Formação 
Guaratubinha do estado do Paraná. Essas formações seriam constituídas por conglomerados que gradam para arcóseos e siltitos, rochas vulcânicas e piroclásticas básicas a ácidas, e siltitos com intercalações de tufos.

Citroni (1998) estabeleceu subdivisões das rochas constituintes da Bacia de Campo Alegre em dois grupos (Bateias e Campo Alegre) e dez formações. Este autor atribuiu a gênese e desenvolvimento da Bacia de Campo Alegre às fases finais da colisão entre as microplacas de Curitiba e Luiz Alves. A bacia teria sido gerada por esforços distensivos relacionados a falhas de direção NNW e alto ângulo. Para o mesmo autor, a deposição teria sido iniciada com conglomerados, arenitos e pelitos de leques aluviais, sistemas fluviais entrelaçados e turbiditos, prosseguindo com derrames de lavas básicas a intermediárias intercaladas com pelitos, e culminando com lavas e depósitos piroclásticos intermediários a ácidos. A Bacia de Corupá foi considerada pelo autor como uma sub-bacia da Bacia de Campo Alegre, preenchida por turbiditos e arenitos da Formação Corupá.

Segundo Citroni (1998) e Citroni et al. (1999), a evolução do magmatismo teria ocorrido por processos de cristalização fracionada de um magma com contaminação crustal subordinada, cristalizado entre $579 \pm 30 \mathrm{Ma}(\mathrm{U}-\mathrm{Pb})$ e $570 \pm 39 \mathrm{Ma}(\mathrm{Rb}-\mathrm{Sr}$ ). Siga Jr. et al. (1999), por sua vez, apresentaram idades de $528 \pm 29$ Ma para riolitos da Bacia de Campo Alegre. Mais recentemente, Cordani et al. (em prep.) obtiveram valores de $595 \pm 16 \mathrm{Ma}$ para zircões datados pelo método U-Pb (SHRIMP), sugerindo correlação das rochas vulcânicas da Formação Campo Alegre com os granitóides peralcalinos da Serra do Mar, enquanto Basei et al. (1998) apresentaram idades U $\mathrm{Pb}$ de $598 \pm 29$ Ma para riolitos da Bacia de Campo Alegre.

\subsubsection{Itajaí}

Dutra (1926) chamou os folhelhos argilosos e argilo-arenosos do vale do Rio Itajaí-Açu (leste do estado de Santa Catarina) de "Série Itajahy", incluindo quartzitos, arcóseos e conglomerados num conjunto verticalizado. Posteriormente, Carvalho e Pinto (1938) atribuiram origem glacial aos conglomerados, correlacionando-os à "Série Camaquã" do estado do Rio Grande do Sul e registrando também a presença de vulcanismo. A origem glacial dos conglomerados foi contestada por Freitas (1943), que atribuiu-lhes origem por deposição em leques aluviais. Seguiramse várias redefinições e mudanças no empilhamento estratigráfico dessas bacias, propostas por autores diversos.

Basei (1985) interpretou a Bacia de Itajaí como sendo uma antefossa molássica relacionada ao Cinturão Dom Feliciano, reconhecendo falhas inversas no limite sul da mesma e dividindo as sucessões litológicas em uma unidade arenítica basal (constituída por arenitos arcosianos, conglomerados, tufos e níveis silticos) e uma unidade siltica no topo (constituída por arenitos, 
siltitos e argilitos laminados). $\mathrm{O}$ autor atribuiu esses depósitos a ambientes fluviais proximais e turbiditos proximais, medianos e distais, estimando uma espessura de $7500 \mathrm{~m}$ e verificando duas fases de deformação que configurariam um monoclinal com vergência contra o cráton.

Macedo et al. (1984) datara sedimentos da Bacia de Itajaí em $542 \pm 18$ e $530 \pm 20 \mathrm{Ma}$, valores estes corrigidos por Basei et al. (1987) para $581 \pm 48$ (sedimentação e diagênese) e $535 \pm 10$ (anquimetamorfismo), com resfriamento a $525 \mathrm{Ma}(\mathrm{K}-\mathrm{Ar})$. Estes últimos autores obtiveram ainda idades de $534 \pm 4 \mathrm{Ma}(\mathrm{Rb}-\mathrm{Sr})$ para intercalações de tufos nos sedimentos da Bacia de Itajaí, e $544 \pm$ $20 \mathrm{Ma}$ pelo método Rb-Sr para o Riolito Apiúna, também intercalado aos sedimentos da bacia.

Entre 1987 e 1991, diversos autores (Appi et al., 1987, 1990; Appi e Cruz, 1990; Krebs et al., 1988) utilizaram conceitos relacionados à Estratigrafia de Seqüências na caracterização das fácies e modelos deposicionais da Bacia de Itajaí, definindo seqüências deposicionais e associações de fácies de leques aluviais, planícies e frentes deltaicas, pró-deltas, plataformas, taludes, leques submarinos, turbiditos e diamictitos, além de tratos de sistemas de mar baixo e alto, transgressões marinhas, seções condensadas, etc. Rostirolla (1991) caracterizou a bacia como de origem flexural relacionada à convergência dos cavalgamentos do Grupo Brusque sobre o Maciço de Joinville, configurando uma bacia de foreland periférica.

Por fim, Citroni (1993) descreveu associações turbidíticas, baciais (depósitos hemipelágicos e de escorregamento subaquoso), transicionais (arenitos de águas rasas, deltaicos e de planícies costeiras), e continentais (leques aluviais e rios entrelaçados) para o Grupo Itajaí, com magmatismo sin-sedimentar subordinado. Segundo o autor, a bacia teria sofrido um cavalgamento pósdeposicional pelo Grupo Brusque na sua borda sul em torno de $535 \mathrm{Ma}$ atrás, sendo sua origem relacionada a um rifteamento continental passivo com transgressão marinha e magmatismo alcalino associado.

Paim et al. (1997), descrevendo traços fósseis de Chancelloria sp. em sedimentos da Bacia de Itajaí, atribuíram idades em torno de $540 \mathrm{Ma}$ para os mesmos. Entretanto, idades mais antigas foram obtidas para esta bacia com relação ao magmatismo associado, datado em $567 \pm 14 \mathrm{Ma}$ (U$\mathrm{Pb})$ por Basei et al. (1999) para o Riolito Apiúna, e em $563 \pm 14 \mathrm{Ma}$ (U-Pb SHRIMP) por Cordani et al. (em prep.), também para o Riolito Apiúna.

\subsubsection{Camaquã e Guaritas}

Carvalho (1932) foi o primeiro a definir a "Série de Camaquan" no Estado do Rio Grande do Sul, constituída por arenitos, folhelhos e conglomerados do Eopaleozóico, sobrepostos a derrames andesíticos e sotopostos discordantemente a sedimentos permianos. Leinz (1939) detectou uma deformação basculando a série, e Leinz et al. (1941) definiram a Formação Maricá como arcósios e folhelhos distintos da "Série Camaquan" e sotopostos à mesma. 
A "Série Camaquan" e a Formação Maricá foram elevadas a Grupos por Goñi et al. (1962), com o Grupo Maricá incluindo também as rochas andesíticas e riolíticas, e o Grupo Camaquã sendo dividido nas formações Camaquã e Guaritas. Robertson (1966) dividiu o Grupo Camaquã nas formações Santa Bárbara, Guaritas e Conglomerado Coxilha, que estariam assentadas discordantemente sobre as rochas vulcânicas e piroclásticas ácidas ("Riolito da Ramada") a intermediárias ("Andesito Hilário") anteriormente reconhecidas na região. Essas rochas vulcânicas, por sua vez, estariam assentadas sobre a Formação Maricá conforme anteriormente definida por Leinz et al. (1941).

Ribeiro et al. (1966) e Tessari e Picada (1966) propuseram um empilhamento estratigráfico para a região como composto pelos sedimentos do Grupo Maricá na base, seguido pelo Grupo Bom Jardim, este último dividido nas formações Arroio dos Nobres (formada por conglomerados e arenitos conglomeráticos do Membro Vargas e ritmitos psamo-pelíticos do Membro Mangueirão) e Crespos (dividida nos membros Acampamento Velho, correspondente ao Riolito da Ramada, e Hilário, correspondente ao Andesito Hilário). Sobre o Grupo Bom Jardim, estaria assentado o Grupo Camaquã, dividido nas formações Santa Bárbara e Guaritas.

Trein e Fuck (1967) correlacionaram o Grupo Camaquã com os grupos Castro e Itajaí e à Formação Guaratubinha, considerando as rochas riolíticas e andesíticas como parte do mesmo.

Ribeiro (1970) considerou o Grupo Bom Jardim como indiferenciado. Posteriormente, Ribeiro e Fantinel (1978) tornaram a dividir o Grupo Bom Jardim em formações, incluindo Maricá, Hilário, Vargas e Acampamento Velho, mantendo o Grupo Camaquã dividido nas formações Santa Bárbara e Guaritas e assentado sobre o Grupo Bom Jardim.

Santos et al. (1978) redefiniram o Grupo Bom Jardim como Grupo Maricá, dividido nas formações Pessegueiro (correspondente à Formação Maricá de Leinz et al., 1941), Cerro dos Martins (correspondente à Formação Arroio dos Nobres e ao Membro Hilário de Ribeiro et al., 1966) e Acampamento Velho.

Fragoso César et al. (1982a, b) definiram duas associações molássicas distintas para a região, sendo a Associação Molássica Sedimentar constituída pela Formação Arroio dos Nobres e Grupo Camaquã, preenchendo uma antefossa denominada Antefossa do Sudeste, e a Associação Molássica Plutono-Vulcano-Sedimentar na borda leste do Cráton Rio de la Plata, constituída pelas formações Hilário e Acampamento Velho. Em seguida, Bonhomme e Ribeiro (1983) dataram frações finas de sedimentos pelo método $\mathrm{K}$-Ar, obtendo idades de $572 \pm 17535 \pm 16 \mathrm{Ma}$ para um anquimetamorfismo no Grupo Camaquã, e de $529 \pm 16$ e $524 \pm 16$ Ma para um evento de diagênese na Formação Guaritas.

Fragoso César et al. $(1984,1985)$ classificaram os sedimentos molássicos da região em molassas precoces e tardias. Soares (1988) incluiu o Grupo Camaquã na categoria de bacias 
falhadas tipo grabens pós-colisionais, juntamente com o Grupo Castro, Formação Guaratubinha (PR) e Formação Campo Alegre (SC).

Fragoso César (1991) reconheceu uma sequiência molássica mais antiga a leste, relacionada à evolução do Cinturão Dom Feliciano (depositada na Antefossa Camaquã e representada pelo Grupo Camaquã, constituído pelas formações Arroio dos Nobres e Guaritas), e uma mais jovem a oeste, relacionada à evolução do Cinturão Ribeira e representada pela bacia de retro-arco de Santa Bárbara. Oliveira e Fernandes (1991), Sayeg et al. (1992a, b) e Machado e Sayeg (1992) foram os primeiros a propor origem associada a transcorrência sinistral para as calhas deposicionais da região.

Netto et al. (1992) posicionaram a bacia na transição Vendiano-Tommotiano, com base em estudos de icnofósseis, e Almeida et al. (1996) dataram riolitos e ignimbritos atribuídos ao Grupo Camaquã pelo método $\mathrm{Rb}-\mathrm{Sr}$ em $545.1 \pm 12.7,546 \pm 12.9$ e $494.9 \pm 15.1 \mathrm{Ma}$.

Paim et al. (1992, 1995) e Paim (1995) analisaram as unidades constituidas por rochas da Bacia do Camaquã sob enfoque da Estratigrafia de Seqüências e estudos de sistemas deposicionais e paleocorrentes, definindo sequêencias deposicionais ou unidades aloestratigráficas cíclicas (alogrupos Maricá, Bom Jardim, Santa Bárbara e Guaritas) limitadas por eventos transgressivos e constituídas por depósitos de sistemas fluviais, leques deltaico-aluviais progradantes e sistemas marinhos, com eventuais intercalações vulcânicas e contribuições de sistemas desérticos relacionados à Formação Guaritas

Mais recentemente, Fambrini (1998) elevou as formações Santa Bárbara e Guaritas a grupos, desmembrando-as do Grupo Camaquã. Segundo este autor, as rochas datadas por Bonhomme e Ribeiro (1983) como Formação Guaritas pertenceriam na realidade ao topo do Grupo Camaquã, e as rochas riolíticas e andesíticas fariam parte do Grupo Crespos, relacionado ao vulcanismo do Arco Bom Jardim e posicionado entre os grupos Camaquã (acima) e Maricá (abaixo). O mesmo autor dividiu o Grupo Camaquã nas formações Santa Fé (constituída por sedimentos de leques conglomeráticos costeiros), Mangueirão (formada por arenitos costeiros e ritmitos constituindo turbiditos, tempestitos e inunditos), Vargas (conglomerados e arenitos conglomeráticos de leques aluviais e costeiros) e João Dias (constituída por arenitos e ritmitos de ambiente marinho raso e deltaico).

Ainda segundo Fambrini (1998), a Bacia de Camaquã estaria compartimentada em diversas sub-bacias por reativações sin-sedimentares das zonas de falhas presentes. Os limites com o embasamento seriam tectônicos, e com o sobreposto Grupo Guaritas seriam por discordância angular. $\mathrm{O}$ autor atribui clima árido a semi-árido às áreas-fontes e à bacia propriamente dita, a qual teria sido formada por abatimento de blocos tectônicos relacionados à reativação pós-magmática dos sistemas de falhas NE-SW Tapera-Emiliano e Passo dos Enforcados, acompanhada de intensa 
subsidência, migração de depocentros e posteriores inversões que tornaram os depósitos do Grupo Camaquã fonte da deposição do Grupo Guaritas. Este, por sua vez, consiste em arenitos, ortoconglomerados e lamitos de sistemas fluviais entrelaçados passando a eólicos, alimentados por leques aluviais e depositados durante o Ordoviciano em discordância angular sobre o Grupo Camaquã. Estes sedimentos foram mais recentemente estudados como Formação Guaritas por Paim (1995) e Silva Filho (1997), tendo Fragoso César et al. (1998) aventado a hipótese de que os mesmos possam constituir uma unidade basal da Bacia do Paraná. 


\section{LITOESTRATIGRAFIA E PETROGRAFIA}

\subsection{CARACTERÍSTICAS GERAIS}

Neste trabahho, a Formação Camarinha foi subdividida em quatro unidades, com base em mapeamento geológico resultante da análise de fotografias aéreas e levantamentos de perfis e seções em campo. Essas unidades foram denominadas Unidade Conglomerática 1, Unidade ArenoLamítica 1, Unidade Conglomerática 2 e Unidade Areno-Lamítica 2 da base para o topo. A distribuição espacial e o empilhamento idealizado dessas unidades podem ser visualizados nas Figs. 3.1, 3.2 e 3.3, e no Mapa Geológico (Anexo I).

De um modo geral, as quatro unidades apresentam, como características mais marcantes, elevada imaturidade mineralógica evidenciada pela presença de minerais e fragmentos líticos relativamente instáveis, submaturidade textural evidenciada pela seleção moderada a ruim dos grãos e ausência de camadas-guia para o estabelecimento de correlações entre as seções. Como características imprimidas posteriormente, percebe-se alto grau de alteração intempérica e oxidação, que conferem às rochas coloração castanho-avermelhada, e uma certa descontinuidade lateral dos afloramentos em campo, dificultando as correlações entre os diferentes corpos litológicos presentes.

Dessas unidades, que serão descritas e detalhadas mais adiante, a Unidade Conglomerática 1 ocorre apenas na Área Sul, tendo sido representada nos mapas geológicos (Figs. 3.1 e 3.2, Anexo I) juntamente com a Unidade Areno-Lamítica 1, devido à sua pouca espessura aflorante (da ordem de poucas dezenas de metros) que não permite sua individualização nas escalas utilizadas (1:150.000 e 1:50.000). A referida unidade foi representada separadamente apenas nas seções geológicas (Anexo I), em escala 1:25.000, e nas seções colunares que serão apresentadas mais adiante. As demais unidades ocorrem tanto na Área Sul como na Área Norte, distribuídas de modo desigual.

Com base na largura aflorante das unidades e seus ângulos de mergulho, foi estimada uma espessura mínima de aproximadamente $3180 \mathrm{~m}$ na Área Sul e $3860 \mathrm{~m}$ na Área Norte para os sedimentos da Formação Camarinha (sendo na Área Sul aproximadamente $1660 \mathrm{~m}$ para as unidades Conglomerática 1 e Areno-Lamítica 1, $1200 \mathrm{~m}$ para a Unidade Conglomerática 2, e $320 \mathrm{~m}$ para a Unidade Areno-Lamítica 2, e na Área Norte aproximadamente $1000 \mathrm{~m}$ para a Unidade ArenoLamítica 1, $1360 \mathrm{~m}$ para a Unidade Conglomerática 2, e $1500 \mathrm{~m}$ para a Unidade Areno-Lamítica 2). Desses totais, cerca de $530 \mathrm{~m}$ foram levantados em seções colunares medidas na Área Sul, as quais serão a seguir expostas neste capítulo.

A escassez e má preservação dos afloramentos na Área Norte não permitiram o estabelecimento das relações de contato entre as unidades naquela região. Entretanto, na Área Sul 


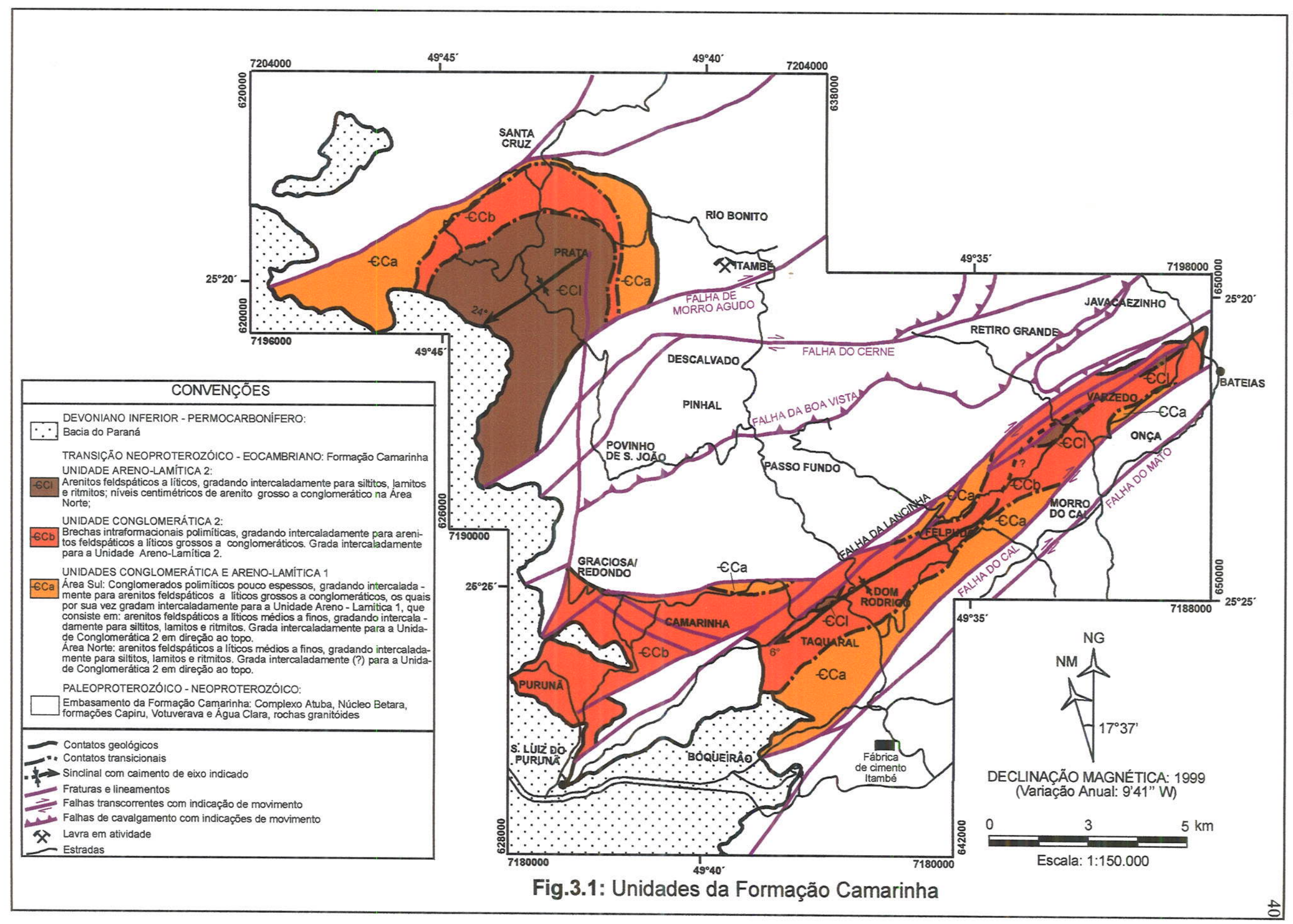




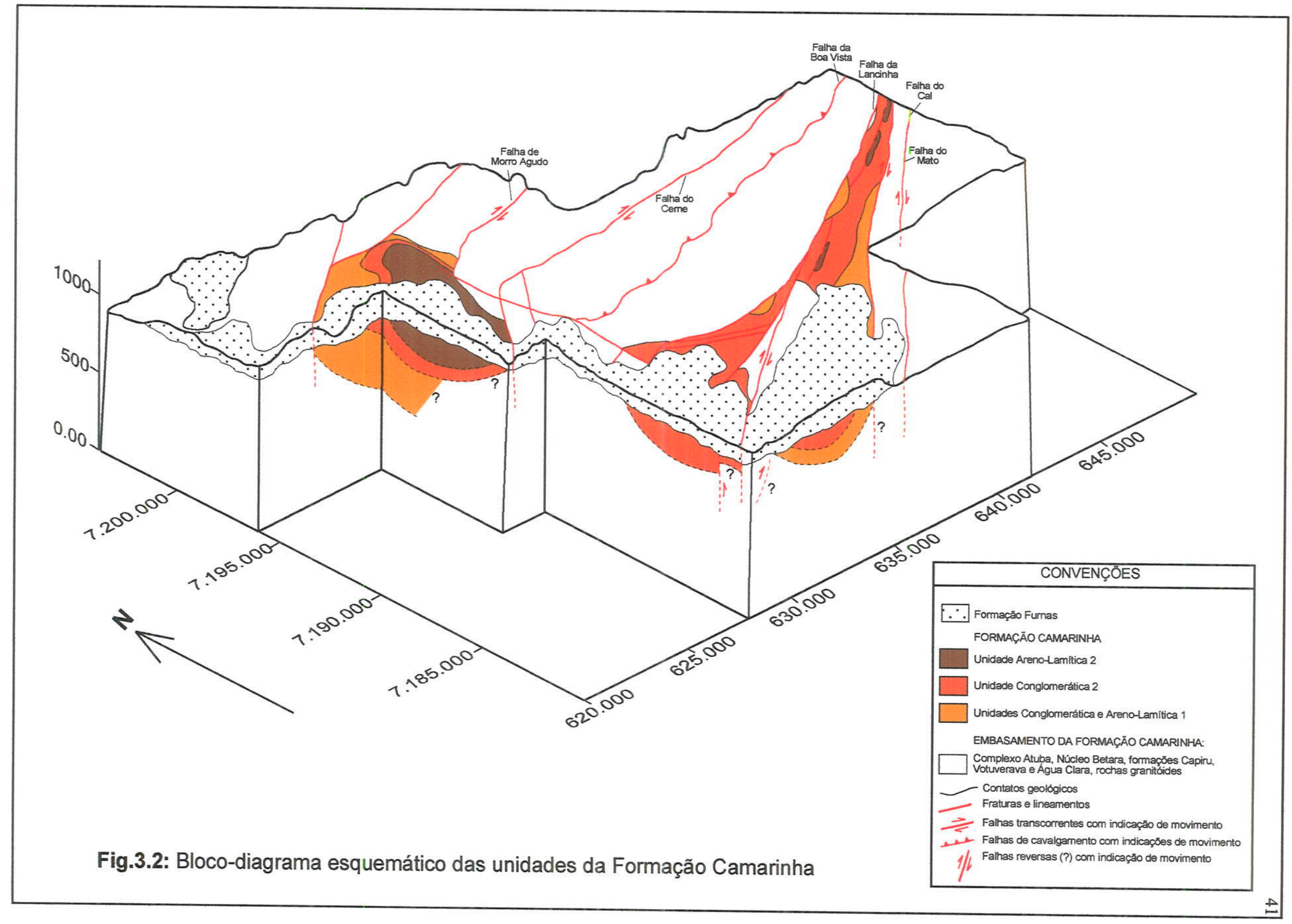




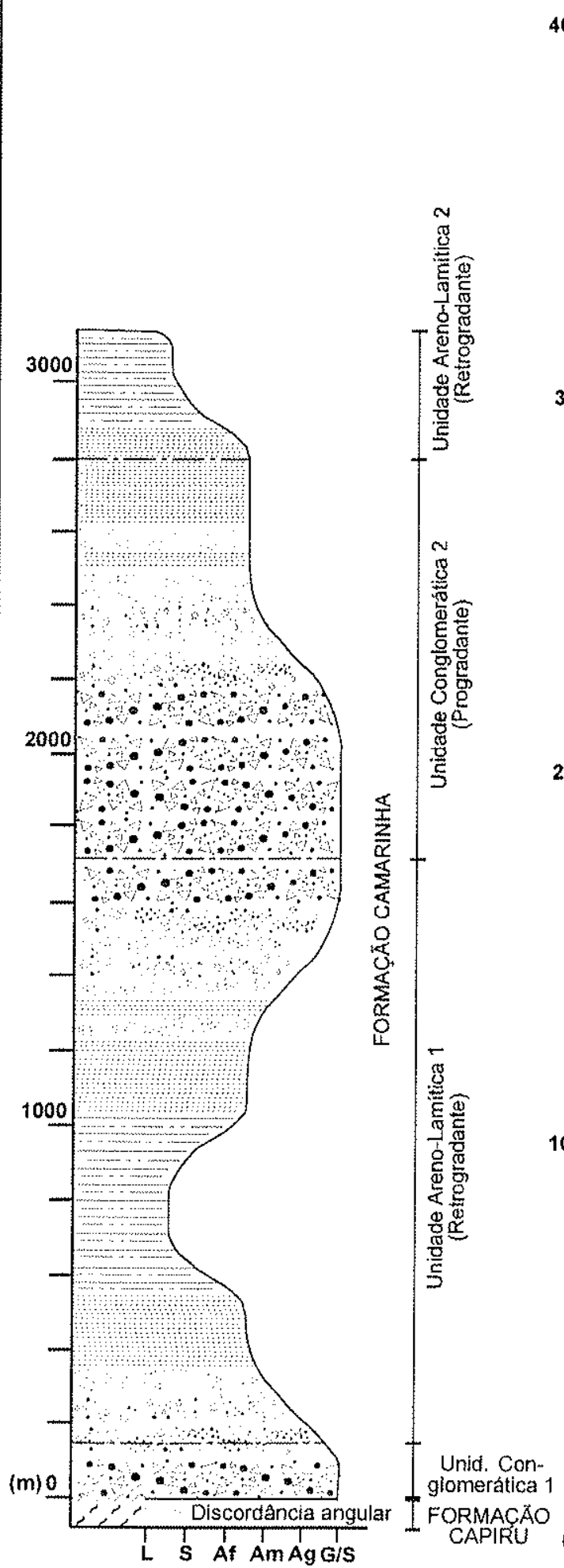

ÁREA SUL.

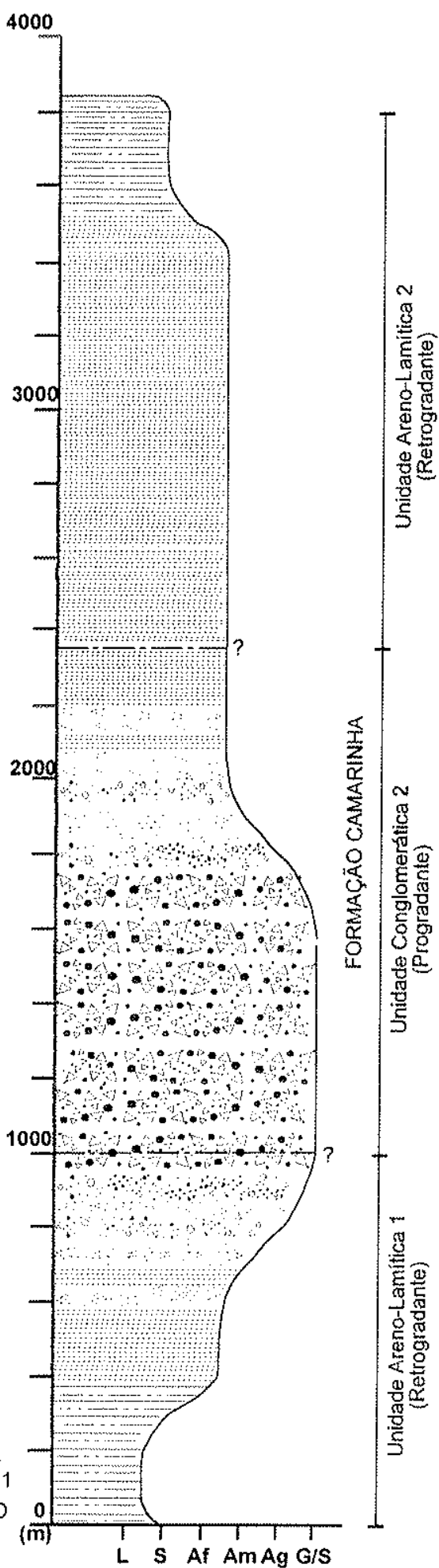

ÁREA NORTE

Fig.3.3: Seçōes esquemáticas ideais das unidades constituintes da Formaçäo Camarinha nas áreas Norte e Sul (baseadas em levantamentos de seçốes locais, com empilhamento resultante de progradaçóes $e$ retrogradações ao longo do tempo)

(Convençōes adaptadas de Lahee, 1952; Compton, 1985; Tucker, 1989; Silva, 1994; CPRM, 1997; IBGE, 1998)

\section{LITOTIPOS}

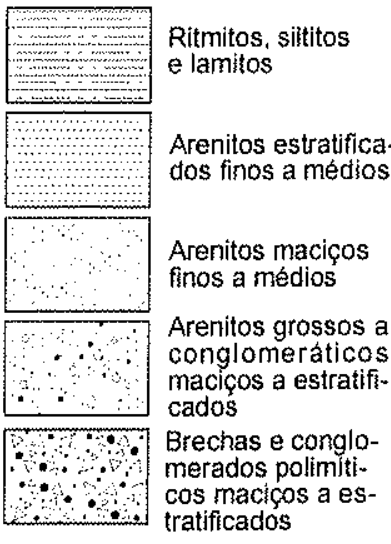

\section{SUPERFICIES}

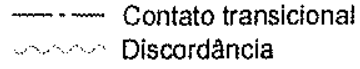

\section{GRANULOMETRIA}

G/S Grânulos e seixos

$\mathrm{Ag}$ Areia grossa

Am Areia média

Af Arela fina

$\$$ Silte

L. Lama

\section{UNIDADES}

Unidade Arenowlamitica 2: Arenitos feld́spáticos a liticos médios a finos, gradando intercaladamente para siltitos, lamitos e ritmitos, com laminacỏes paralelas, onduladas, cruzadas e estruturas de sobrecarga; niveis centimétricos de arenito grosso a conglomerático na Area Norte Unidade Conglomerática 2: Conglomerados e brechas intraformacionais polimiticos, macicos a incipientemente estratificados, imaturos, gradando intercaladamente para arenitos feldspáticos a líticos grossos a conglomeráticos, também macicos a incipientemente estratificados, localmente com estratificaça cruzada, imaturos textural e mineralogicamente. Grada interca ladamente para as lentes da Unidade Areno-Lamitica 2.

Unidade Areno-Lamítica 1 .

arenitos feldspáticos a líticos médios a finos, gradando intercaladamente para siltitos, lamitos e ritmitos, com laminacões paralelas, onduladas, cruzadas e estruturas de sobrecarga. Grada intercaladamente para a Unidade Conglomerática 2 em direçå̃o ao topo

Unidade Conglomerática 1:

Conglomerados polimíticos macicos a incipientemente estra tificados, imaturos, gradando intercaladamente para arenitos feldspáticos a líticos grossos a conglomeráticos, também macicos a incipientemente estratificados, localmente com estratificação cruzada, imaturos textural e mineralogicamente 
estes contatos puderam ser estabelecidos como sendo transicionais, na forma de intercalações que podem representar interdigitações laterais. Não ocorrem seções-tipo contínuas que pudessem representar o empilhamento completo das unidades constituintes da Formação Camarinha, porém foram levantadas quatro seções de referência, mostrando a constituição e empilhamento de parte das unidades Conglomerática 1, Areno-Lamítica 1 e Conglomerática 2, bem como a transição entre as mesmas. A seção da Fig.3.4, correspondente ao ponto S102a-b, representa a transição da Unidade Conglomerática 1 para a porção basal da Unidade Areno-Lamítica 1, e as seções da Fig.3.5, correspondentes aos pontos S104 e S105, representam a porção basal a intermediária da Unidade Areno-Lamítica 1, tendo sido ambas levantadas na localidade de Boqueirão (Área Sul), ao longo da rodovia BR-277 (sentido Curitiba-Palmeira). Já a seção da Fig.3.6, correspondente ao ponto S71amb, mostra a porção intermediária a superior da Unidade Areno-Lamítica 1 e sua transição para a Unidade Conglomerática 2, tendo sido levantada entre as localidades de Dom Rodrigo e Felpudo (Área Sul). Não foi possível obter boas seções mensuráveis para a representação da Unidade ArenoLamítica 2, tampouco para a representação dessas unidades na Área Norte.

Destas seções, a representada pela Fig.3.4, mostrando a transição da Unidade Conglomerática 1 para as porções basais da Unidade Areno-Lamítica 1, foi originalmente levantada pelos geólogos M.Sc. José Henrique Godoy Ciguel e José Roberto de Góis no ano de 1987, tendo desde então permanecido inédita, exceto por uma pequena publicação resumida em Góis (1990). O atual mau estado de conservação do corte então levantado, que apresenta-se intensamente intemperizado e parcialmente coberto por vegetação e obras de contenção, fez com que neste trabalho se optasse pela utilização da seção mais completa levantada pelos referidos geólogos, com a devida autorização do M.Sc. José R. de Góis, trazendo-a assim ao conhecimento público, devidamente acrescida de informações adicionais obtidas no decorrer do atual trabalho. Já as demais seções foram todas levantadas ao longo deste trabalho.

As seções levantadas representam empilhamentos estratigráficos locais, sendo este empilhamento provavelmente resultante de depósitos inicialmente penecontemporâneos que sofreram retrogradações e progradações ao longo do tempo, conforme será discutido no Cap. 4 deste trabalho.

A Formação Camarinha apresenta contatos por discordância angular com seu embasamento, sendo esses contatos freqüentemente truncados por falhas. A mais importante destas falhas é a Falha da Lancinha, que corta a Área Sul e é responsável pela verticalização e truncamento de camadas, brechação de rochas e estiramento de clastos, e geração de clivagem de fratura, dobras escalonadas e estruturas rúpteis diversas. Essas feições e estruturas serão descritas e analisadas no Cap.5 deste trabalho. Outros lineamentos importantes são as falhas do Cal, responsável pelo 

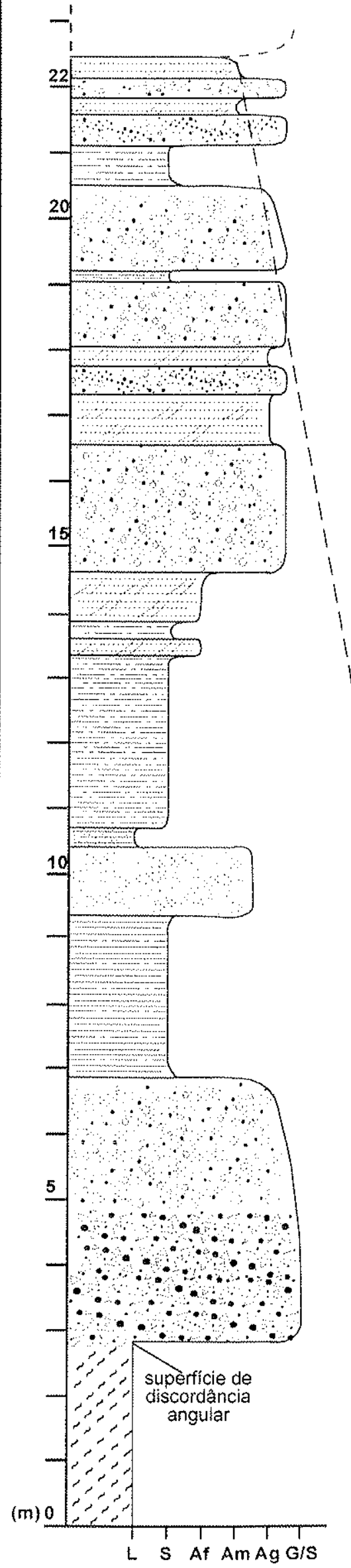

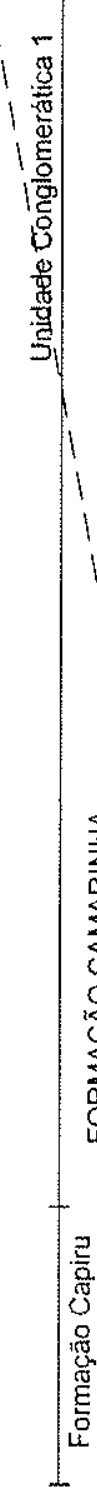

45. (cont. pág.43)

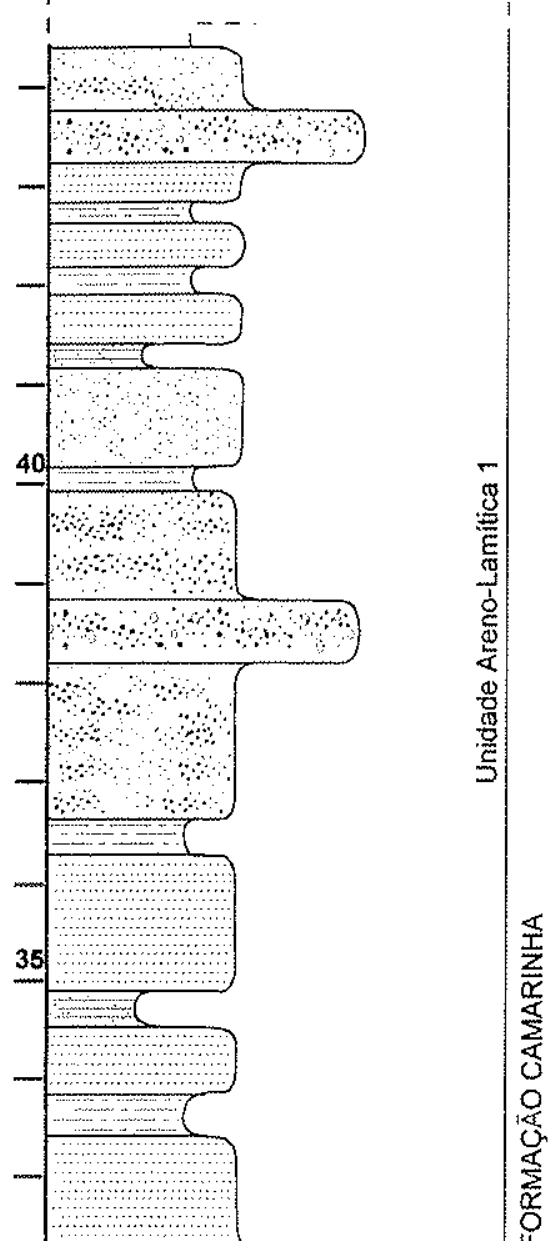

1

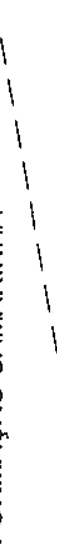

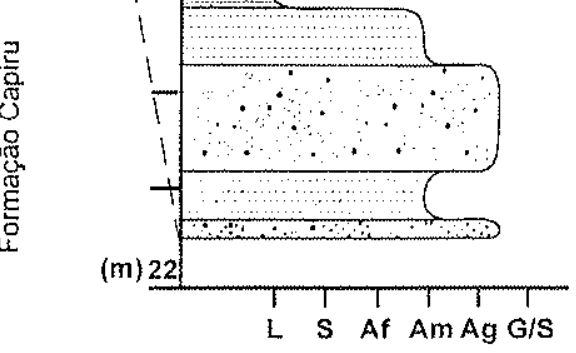

\section{LEGENDAS}

LITOTIPOS

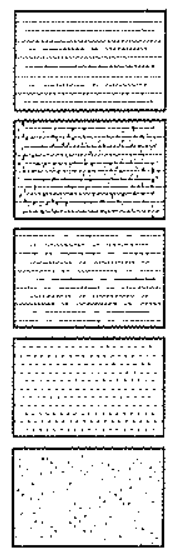

Ritmitos

Lamitos

Siltitos

Arenitos estratificados finos a médios

Arenitos maciços finos a médios

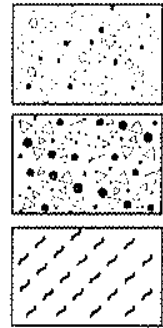

Arenitos grossos a conglomeráticos maciços a estratificados

Brechas e conglomerados polimíticos ma ciços a estratificados

Filitos

\section{LAMINACÕES E ESTRATIFICAÇÖES}

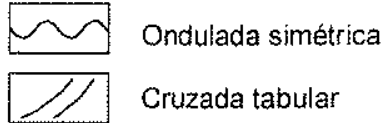

\section{SUPERFICIES}

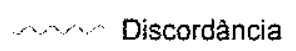

\section{GRANULOMETRIA}

G/S Grànulos e seixos
Ag Areia grossa
Am Areia média
Af Areia fina
S Sifte
L Lama

Fig.3.4a: Seção colunar das unidades Conglomerática $1 \mathrm{e}$ Areno-Lamítica 1 da Formação Camarinha, representando a transição entre ambas e a porção basal da Unidade Areno-Lamítica 1 (Ponto S102, localidade de Boqueirăo, Anexo II); empilhamento local resultante de progradações e retrogradacões ao longo do tempo (Modificada do levantamento efetuado em 1987 por J. H. G. Ciguel e J. R. Góis)

(Convencões adaptadas de Lahee. 1952; Compton, 1985: Tucker 1989; Silva, 1994; CPRM, 1997; IBGE, 1998) 


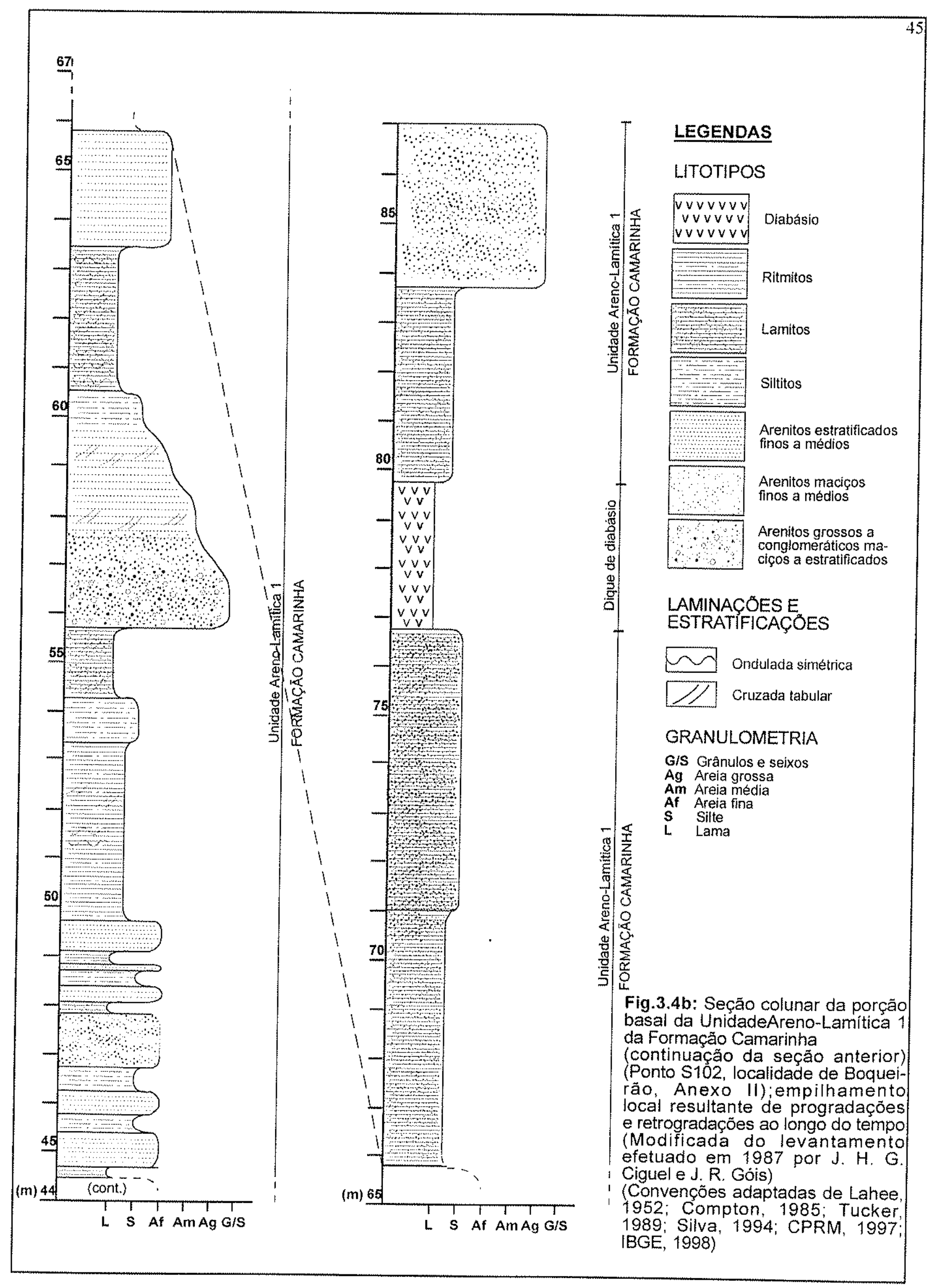




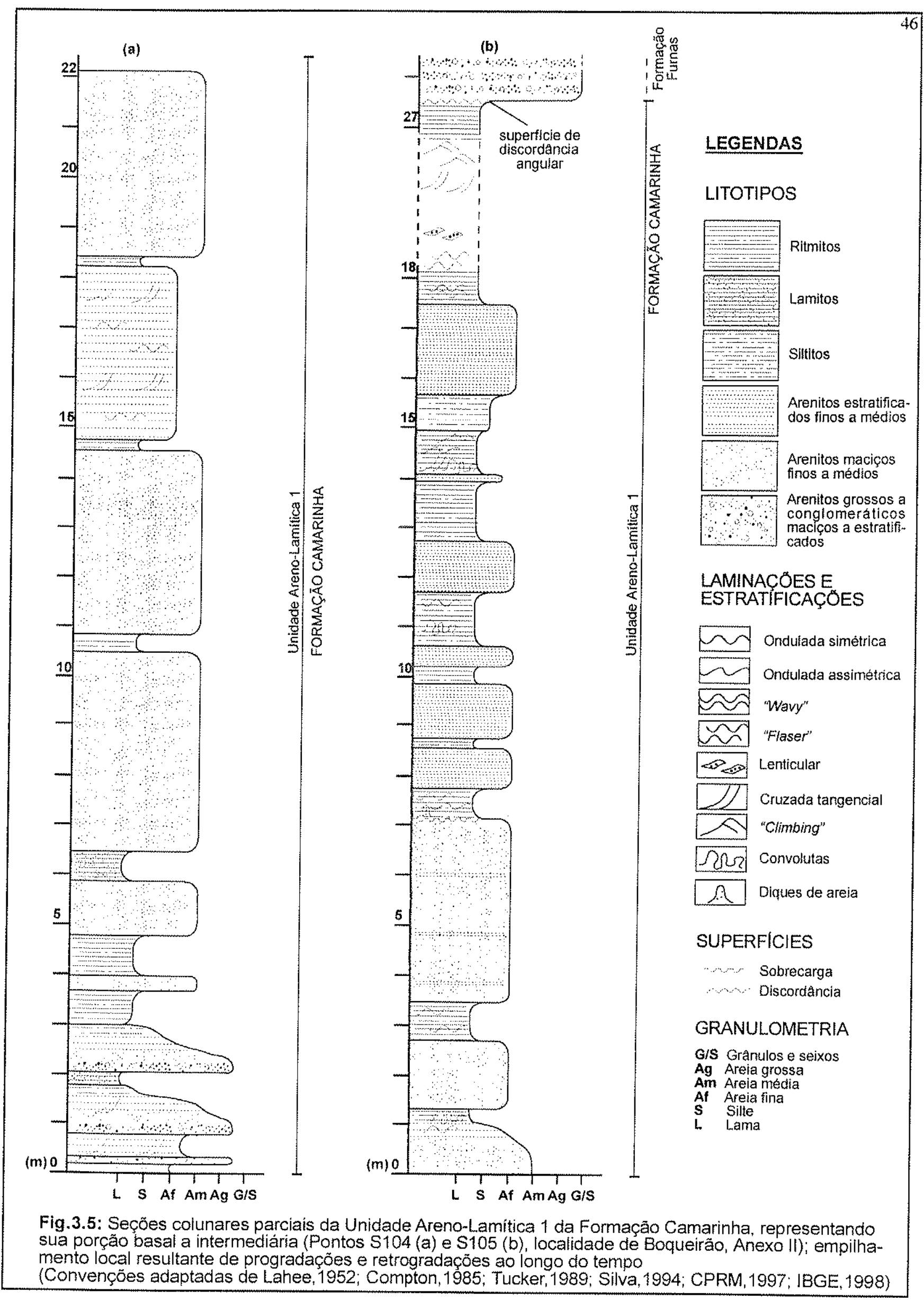




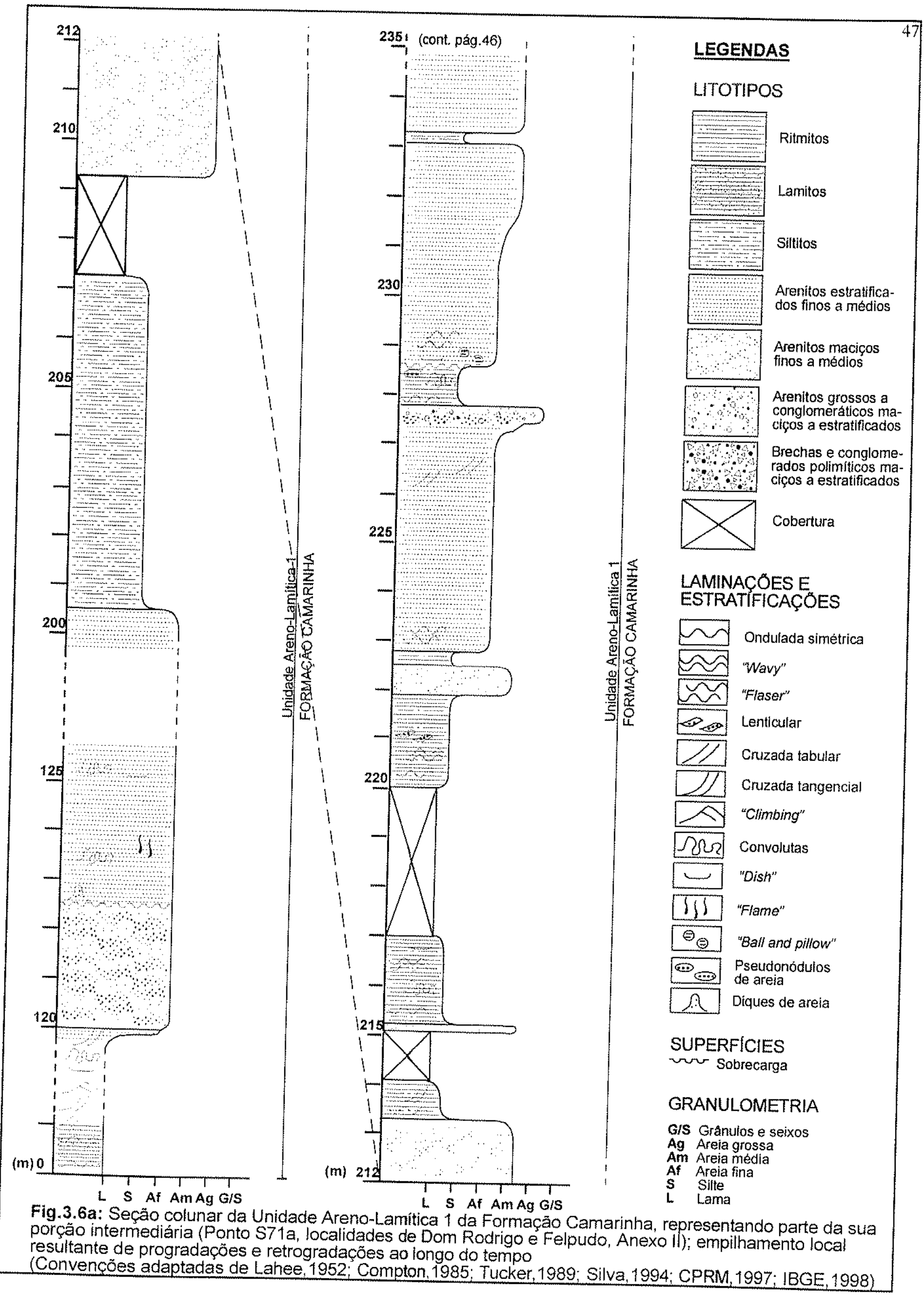




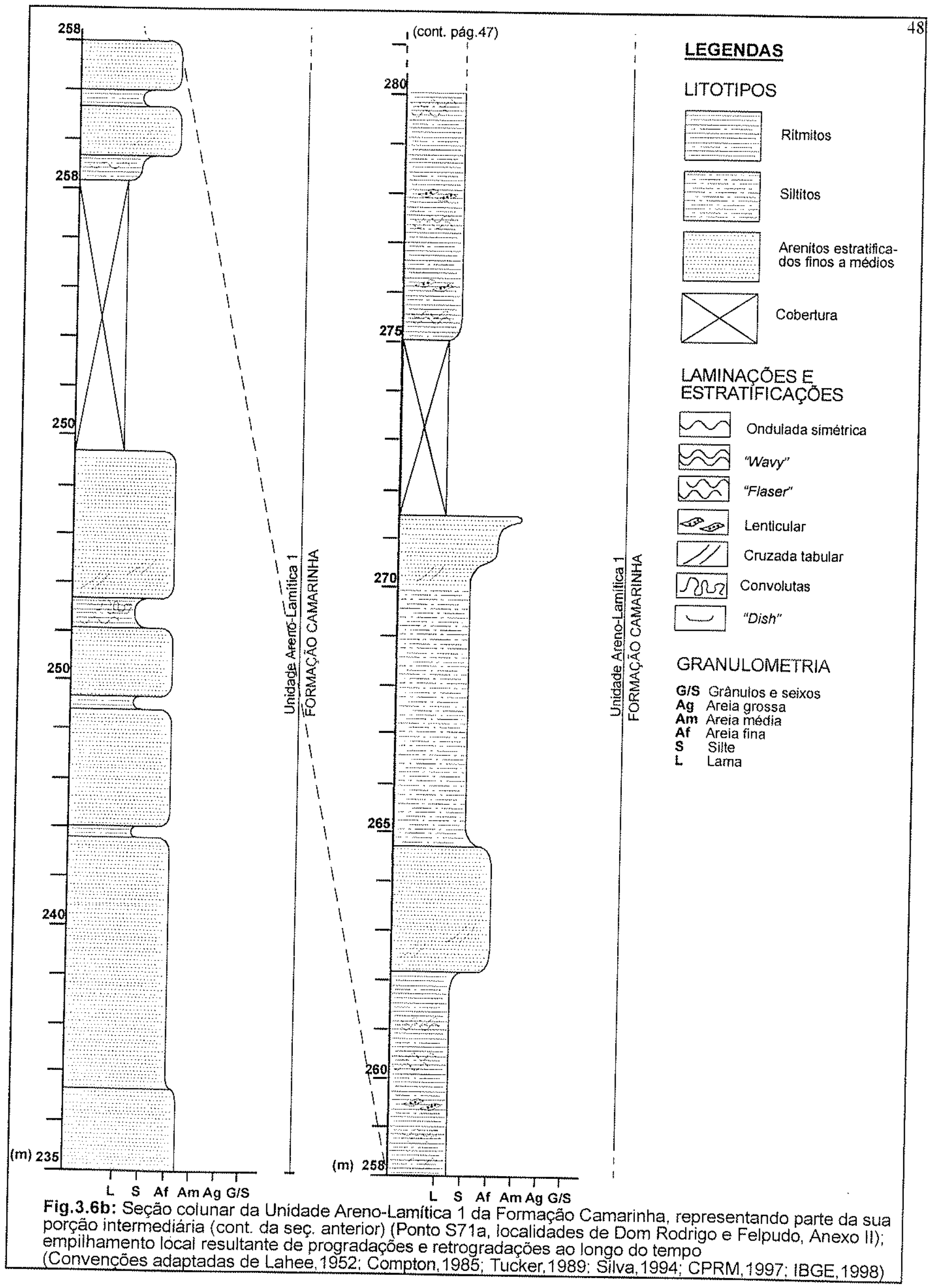




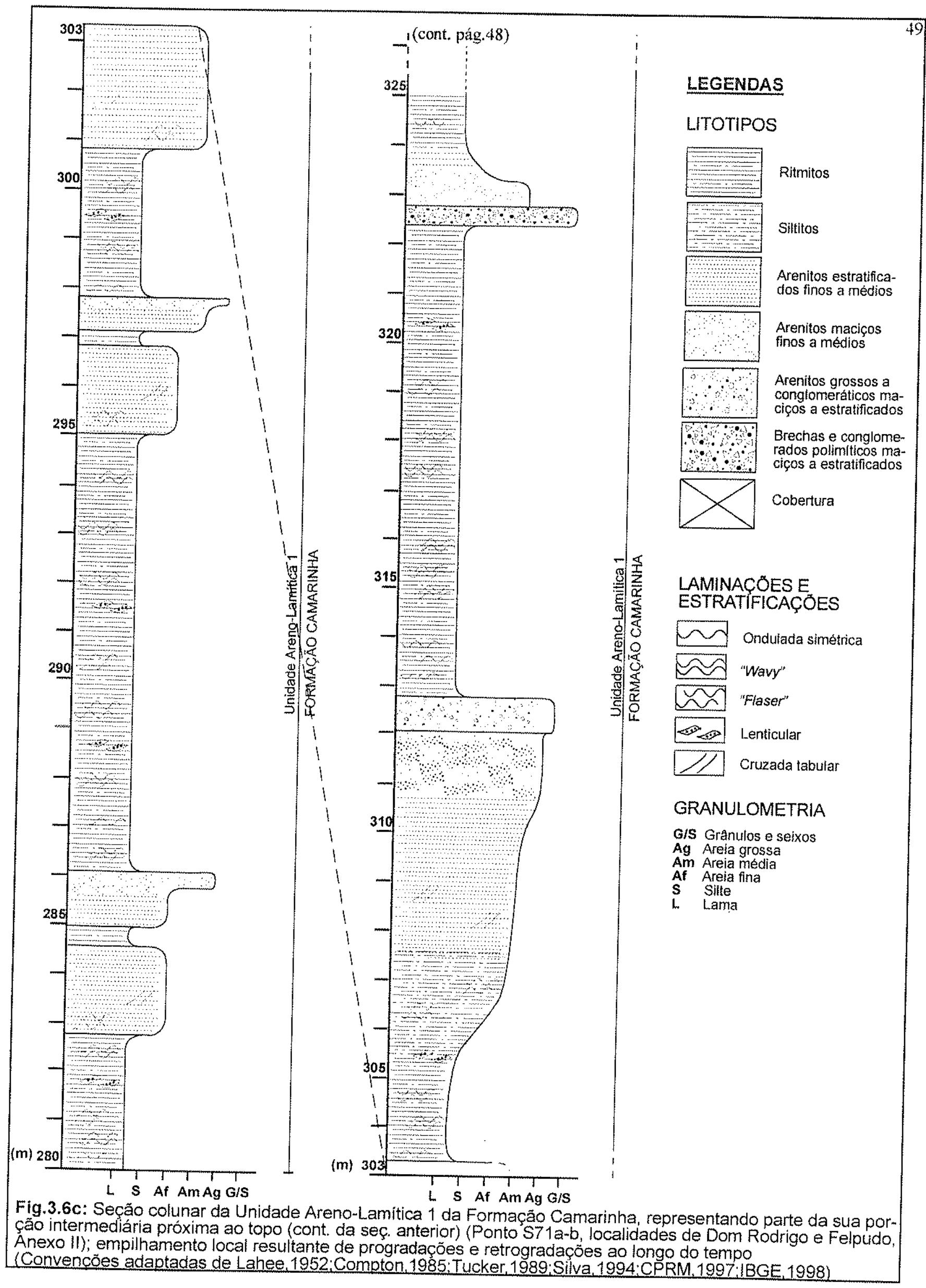




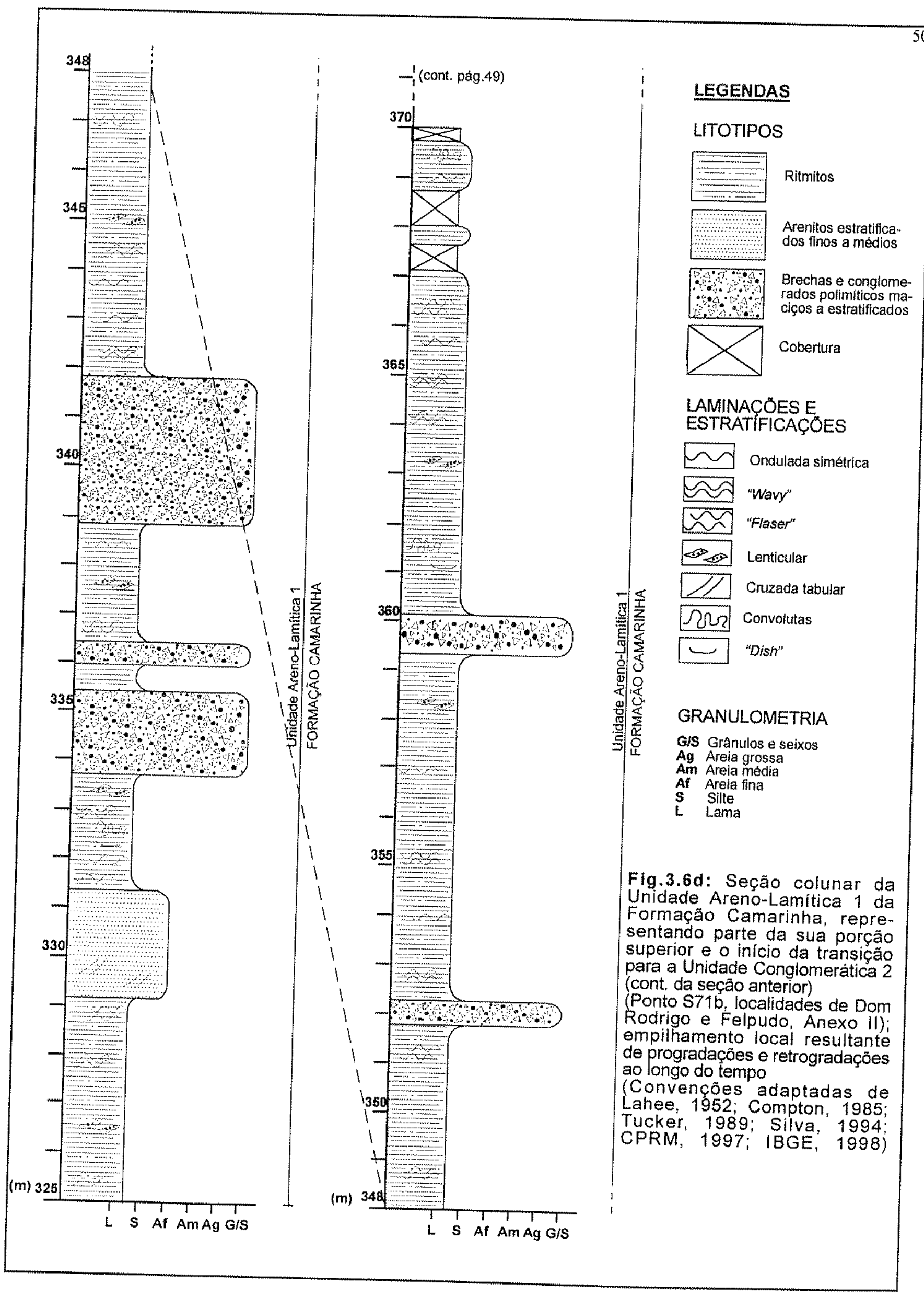




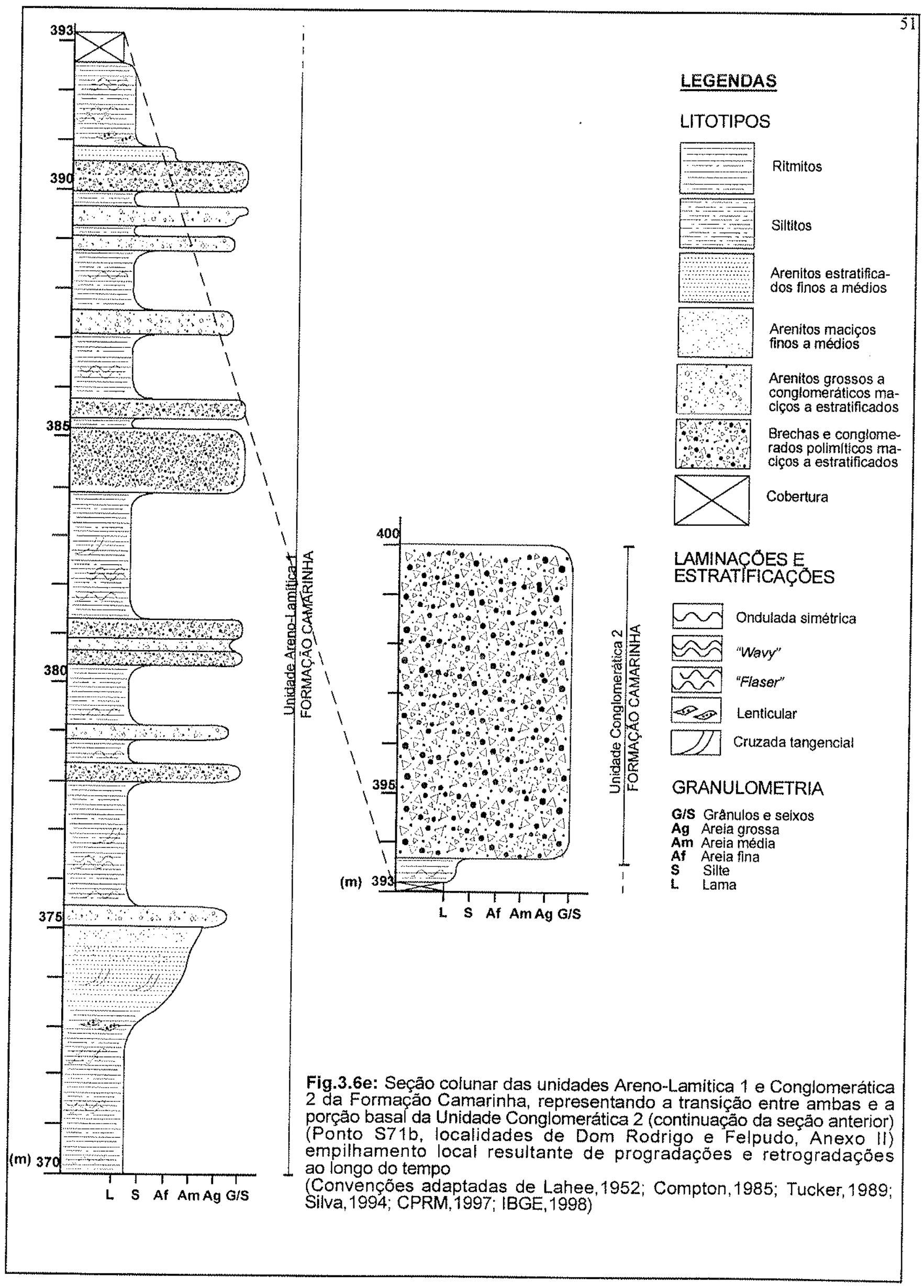


truncamento, verticalização e brechação de camadas próximas ao limite sudeste da Área Sul, e de Morro Agudo, que trunca parcialmente os limites da Área Norte.

As unidades da Formação Camarinha apresentam-se dobradas na forma de sinclinais, com direções de camadas predominantemente para nordeste com mergulhos para noroeste e sudeste, e localmente leste-oeste com mergulhos para sul, como na região da Área Sul imediatamente ao norte da Falha da Lancinha (localidades de Taquaral, Camarinha e Purunã) ou na região do fechamento do sinclinal na Área Norte (localidade de Prata). Essas estruturas também serão devidamente analisadas no Cap. 5 deste trabalho.

Eventualmente ocorrem, entre as localidades de Onça e Varzedo (nordeste da Área Sul), depósitos recentes relacionados às brechas e conglomerados da Unidade Conglomerática 2, na forma de tálus e colúvios pouco espessos, com predomínio de matriz mal selecionada e imatura, e estrutura maciça. Essas ocorrências, no entanto, são pontuais, não visiveis em fotografias aéreas e não mapeáveis na escala utilizada.

A pouca espessura da Unidade Conglomerática 1, prejudicando sua mapeabilidade na escala adotada, bem como a falta de seções-tipo contínuas e completas que pudessem ser levantadas incluindo a Unidade Areno-Lamítica 2, fizeram com que no presente trabalho não se optasse pela denominação das unidades como membros da Formação Camarinha. Do mesmo modo, a ausência de discordâncias internas, seções condensadas, superfĩcies de máxima inundação e outros marcadores cronoestratigráficos dificulta a adoção da Estratigrafia de Seqüências como metodologia de análise dos depósitos da formação.

\subsection{ASPECTOS DE CAMPO}

\subsubsection{Unidade Conglomerática 1}

A Unidade Conglomerática 1 aflora com até cerca de $30 \mathrm{~m}$ de espessura na base na Unidade Areno-Lamítica 1, em dois pontos adjacentes ao limite sudeste da Área Sul (S102 e S59, localidades de Boqueirão e Felpudo, Anexo II) e em um ponto adjacente ao limite noroeste da mesma área (S126, localidade de Felpudo, Anexo II). Seu contato com o embasamento (filitos das formaçôes Capiru e Votuverava) é visível na localidade de Boqueirão (ponto S102, Anexo II), mostrando nítida discordância angular, com os conglomerados da Formação Camarinha mergulhando $60^{\circ}$ para noroeste e os filitos da Formação Capiru mergulhando $65^{\circ}$ para sudeste. Este contato encontra-se brechado por falhamento (Falha do Cal) (Foto 3.1), e embora não seja visível na região de Felpudo, deve também estar truncado por falhas, considerando-se a brechação observada 
nas rochas e a presença das falhas do Cal e da Lancinha na região, evidenciada em fotografias aéreas e imagens de satélite.

A unidade consiste em conglomerados polimíticos e arenitos conglomeráticos a grossos e médios, maciços a incipientemente estratificados. Os conglomerados apresentam clastos subangulosos a subarredondados com até $5 \mathrm{~cm}$ de tamanho, constituídos por filitos, quartzo, quartzitos, rochas carbonáticas (mármores dolomíticos?), granitos e mais raramente rochas metabásicas (?), em uma matriz que varia de síltica a arenosa, imatura e com seleção média a ruim. Essa matriz possui composição feldspática a lítica, micácea, com grãos subangulosos e subarredondados de quartzo, feldspato caulinizado, quartzito, filito e rochas carbonáticas. $O$ cimento é argiloso.

Os conglomerados gradam e intercalam-se com arenitos conglomeráticos a grossos e médios, micáceos, que inicialmente ocorrem como níveis centimétricos a decimétricos, aumentando progressivamente em freqüência e espessura. Apresentam composição feldspática a lítica e micácea, com grãos milimétricos angulosos, subangulosos e subarredondados de quartzo, feldspato caulinizado, quartzito, filito, rochas carbonáticas e eventualmente graníticas em meio a pouca matriz e cimento também argiloso. Nas frações médias, pode-se verificar a ocorrência de incipientes estratificações gradacionais, paralelas e cruzadas tabulares.

O elevado grau de alteração intempérica dessas rochas não permitiu a confecção de lâminas delgadas para estudo textural e composicional visando uma classificação mais definida e uma análise de proveniência, tanto para os conglomerados como para os arenitos.

Níveis de granulação mais fina, como arenitos finos e siltitos maciços a incipientemente estratificados, ritmitos arenosos e síltico-argilosos, e até lamitos, ocorrem subordinadamente nesta unidade, com espessuras desde milimétricas a centimétricas, no contato com o embasamento, até decimétricas a métricas, à medida em que ocorre a transição para a Unidade Areno-Lamítica 1 de sudeste para noroeste, quando então passam a predominar. Esta transição pode ser visualizada na seção colunar da Fig.3.4a, caracterizando uma granodecrescência das sucessões, da base a sudeste para o topo a noroeste.

\subsubsection{Unidade Areno-Lamítica 1}

Na Área Sul, aflora em uma faixa de direção NE-SW adjacente ao limite sudeste da mesma (localidades de Boqueirão, Dom Rodrigo, Felpudo, Varzedo e Onça), e em uma lente junto ao limite noroeste da mesma área na localidade de Felpudo. Ocorre ainda em uma pequena lente de direção EW entre as localidades de Taquaral e Camarinha. Na Área Norte, ocorre como uma faixa 
dobrada na forma de um sinclinal com fechamento para nordeste, entre as localidades de Rio dos Matos, Santa Cruz e Itambezinho.

Esta unidade consiste em arenitos médios a finos, que gradam e intercalam-se da base para o topo com siltitos, lamitos e ritmitos arenosos e síltico-argilosos. Os arenitos, assim como os da Unidade Conglomerática 1, também são feldspáticos a líticos e micáceos, medianamente selecionados, com grãos subangulosos a subarredondados de quartzo, feldspato caulinizado, quartzito, filito, rochas carbonáticas e mais raramente xistos, com pouca matriz e cimento argiloso. Níveis finos e médios desses arenitos intercalam-se ritmicamente, mostrando estruturas maciças (Foto 3.2) a incipientemente estratificadas. À medida em que aumenta a espessura e freqüência dos níveis mais finos, ocorrendo nítida granodecrescência, observam-se também estratificações cruzadas tabulares e acanaladas.

Entre a porção basal desta unidade, onde predominam os sedimentos arenosos mais grossos, e a porção intermediária, onde predominam os sedimentos síltico-argilosos, ocorrem pacotes gradacionais de até $50 \mathrm{~cm}$ de espessura com base erosiva (Foto 3.3) (ponto S103, localidade de Boqueirão, Área Sul - Anexo II). Esses pacotes são constituídos por uma base conglomerática de espessura centimétrica, rica em intraclastos síltico-argilosos de tamanho também centimétrico (Foto 3.4), gradando para arenitos médios com estratificações paralelas, cruzadas e climbings, e para arenitos médios a finos que podem apresentar ondulações simétricas e assimétricas de interferência no topo (Fotos 3.5 e 3.6), semelhantes do ponto de vista descritivo a hummockies, porém apresentando menor porte,

Os siltitos, quando em níveis mais espessos (decimétricos a métricos), apresentam-se maciços e com fraturamento conchoidal característico. Entretanto, ocorrem mais comumente como níveis milimétricos a centimétricos intercalados com lamitos, constituindo ritmitos bem laminados. Esses níveis sílticos e lamíticos ocorrem subordinadamente quando próximos à base da Unidade Areno-Lamítica 1, aumentando progressivamente em frequûencia e espessura, até passarem a predominar na porção intermediária da mesma unidade. Esta granodecrescência pode ser observada nas seções colunares representadas nas Figs. 3.4b, 3.5 e 3.6a, b e c.

Onde predominam os lamitos e ritmitos, na porção intermediária da Unidade ArenoLamítica 1, verificam-se abundantes laminações paralelas, onduladas simétricas (mais raramente assimétricas) e cruzadas tangenciais e climbings, além de laminações wavy, flaser e lenticulares (Fotos 3.7 a 3.13), estruturas deformacionais na forma de convolutas (Foto 3.14), estruturas de sobrecarga e escape de água na forma de flames, pseudonódulos de areia e, mais raramente, dish, ball and pillow e diques de areia. Associadas a essas estruturas deformacionais, ocorrem feições de rompimento de níveis arenosos e sílticos por escape de água (Fotos 3.15 e 3.16), evidenciando 

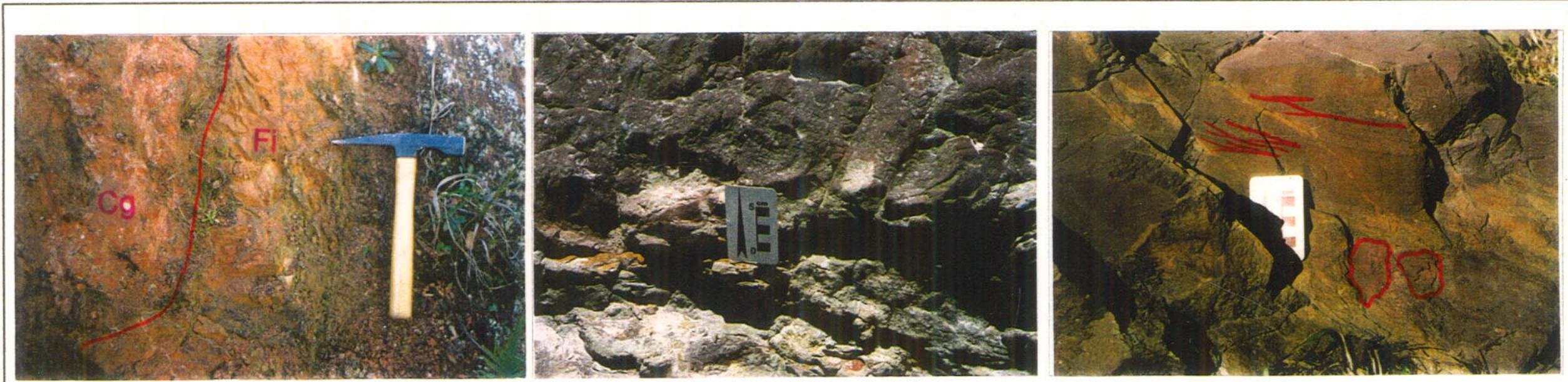

FOTO 3.1: Contato entre filitos da Formação Capiru FOTO 3.2: Arenito médio a fino, maciço, da Unida(Fi) e conglomerados da Unidade Conglomerática de Areno-Lamítica 1 da Formação Camarinha (pon1 da Formação Camarinha $(\mathrm{Cg})$ (ponto $\mathrm{S102}$, to $\mathrm{S105}$, localidade de Boqueirão, Ár ea Sul - Anexo localidade de Boqueirão, Área Sul - Anexo II) II)

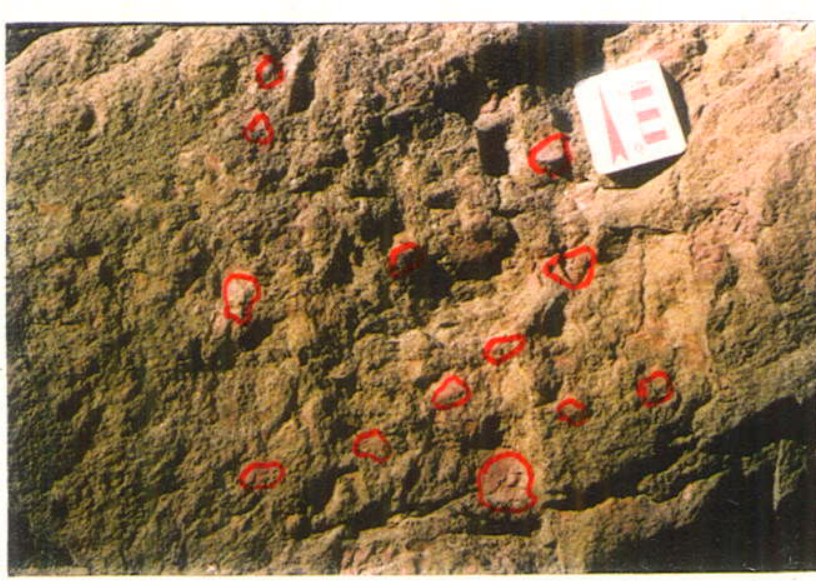

FOTO 3.4: Intraclastos siltico-argilosos em arenitos de base grossa a conglomerática da Unidade Areno-Lamítica 1 da Formação Camarinha (ponto S103, localidade de Boqueirão, Área Sul Anexo II)

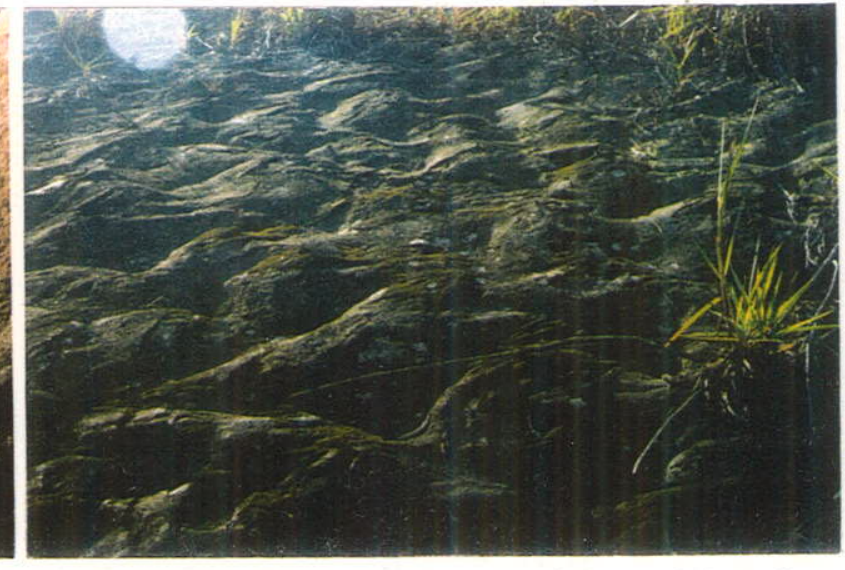

FOTO 3.5: Marcas onduladas simétricas de interfe rência em arenitos médios a finos da Unidade Areno-Lamítica 1 da. Formação Camarinha (ponto S103, localidade de Boqueirão, Área Sul - Anexo II)
FOTO 3.3: Arenitos gradacionais da Unidade Areno-Lamítica 1 da Formação Camarinha, mostrando base conglomerática com intraclastos siltico-argilosos passando a arenitos com estratificaçãa
paralela e cruzada climbing, seta indica topo de camada para norte; paralela e cruzada climbing, seta indica topo de camada para norte: direção aparente de paleocorrente para noroeste (direita da foto)

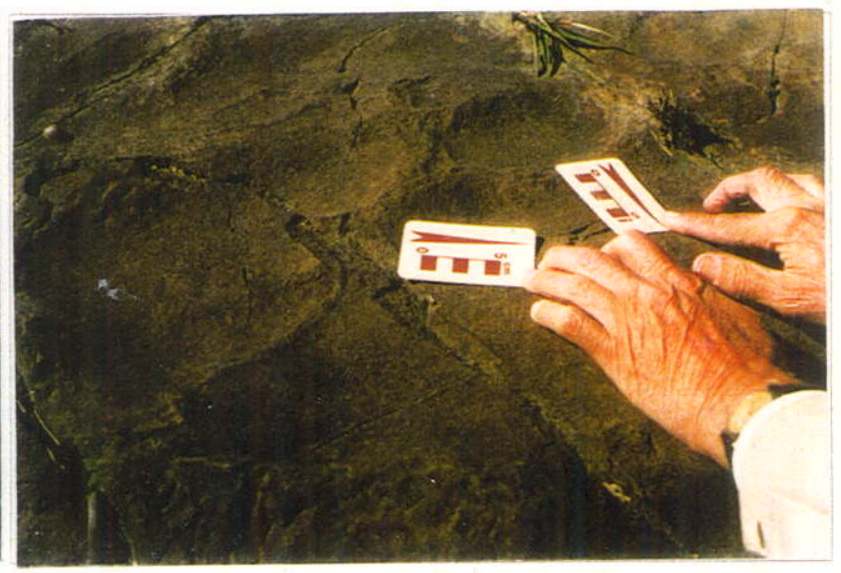

FOTO 3.6: Marcas onduladas assimétricas de interfe rência em arenitos médios a finos da Unidade Areno-Lamítica 1 da Formação Camarinha; setas indicam direções de paleocorrentes para noroeste (ponto S103, localidade de Boqueirão, Área Sul - Anexo II) 


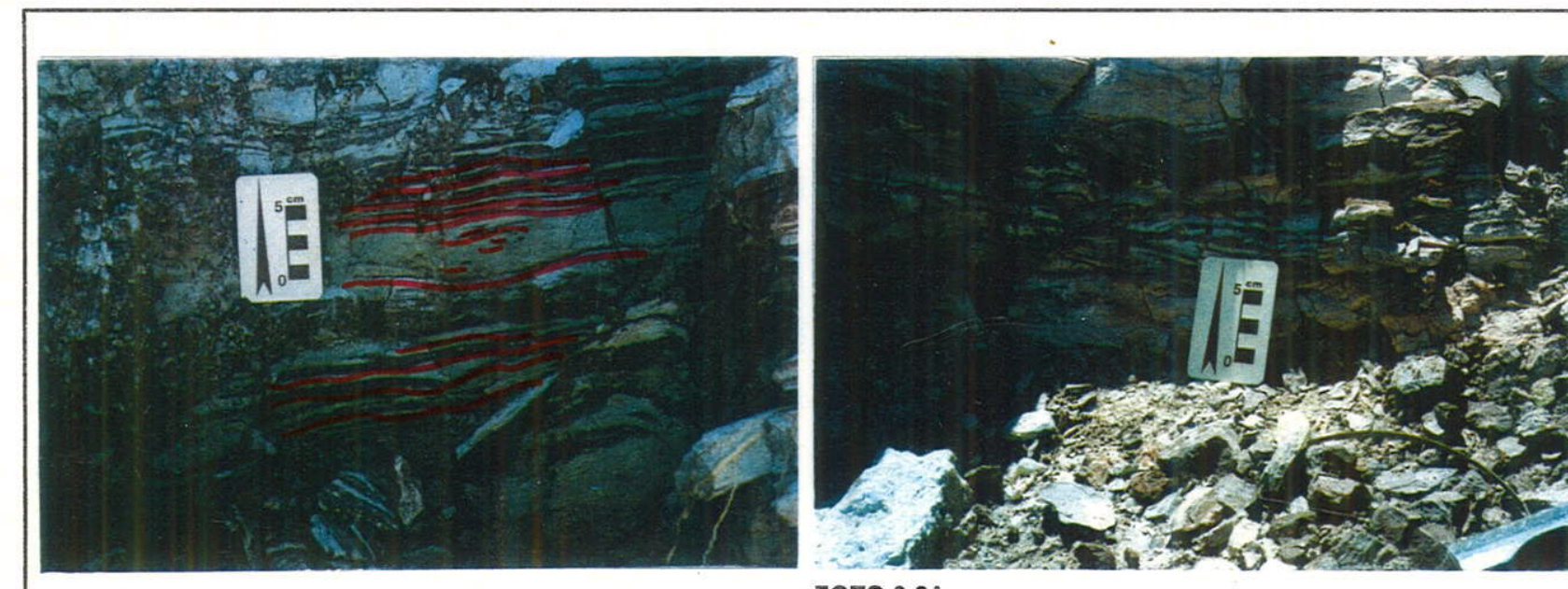
FOTO $3.8 \mathrm{~A}$

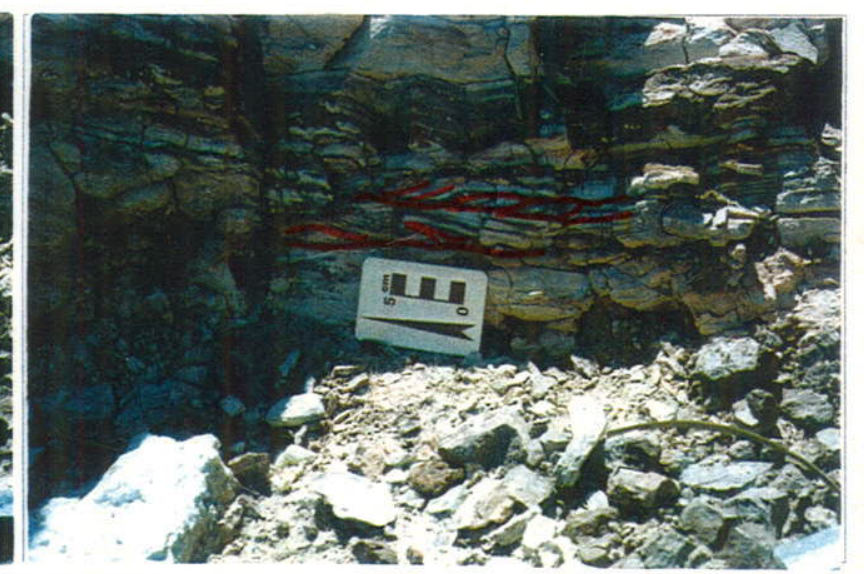

FОTО $3.8 B$

FOTO 3.7: Laminações paralela, wavy e flaser em ritmitos da Unidade Areno-Lamítica 1 da Formação Camarinha (ponto S105, localidade de Boqueirão,

FOTO 3.8: Laminações paralela, ondulada, wavy, lenticular e cruzada tangencial em ritmitos da Unidade Areno-Lamítica 1 da Formação Camarinha; seta indica topo de camada para norte (A) e direção aparente Área Sul - Anexo II)
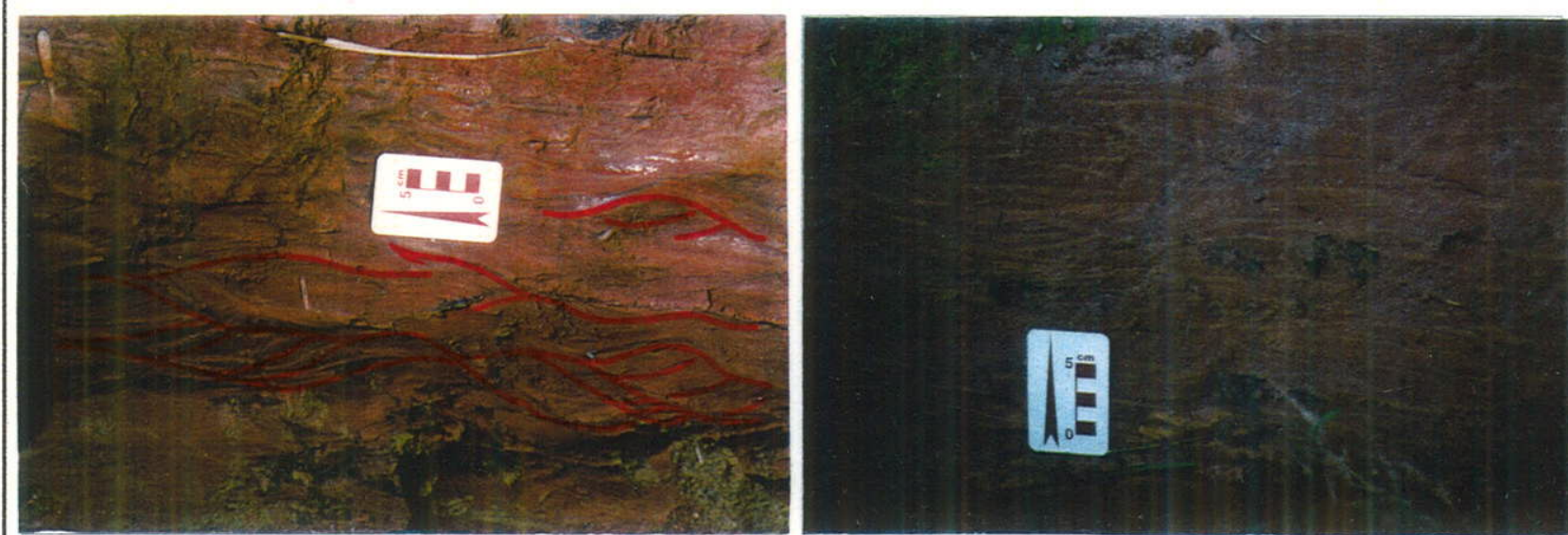

FOTO $3.10 \mathrm{~A}$

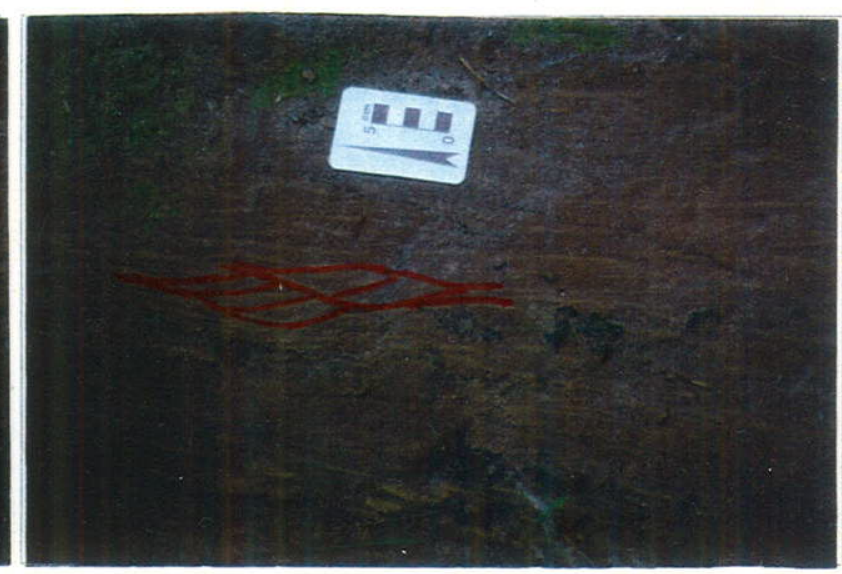

FOTO $3.10 B$

FOTO 3.9: Laminações cruzadas climbing em lamitos FOTO 3.10: Laminações cruzadas climbing e lenticulares em ritmitos da Unidade Areno-Lamítica 1 da da Unidade Areno-Lamítica 1 da Formação Cama- Formação Camarinha; seta indica topo de camada para norte (A) e direção aparente de paleocorrente rinha; seta indica direção aparente de paleocor- para oeste (B) (ponto \$71a, localidade de Dom Rodrigo, Área Sul - Anexo II)

rente para oeste; topo de camada para norte (alto da

foto) (ponto S71a, localidade de Dom Rodrigo, Área Sul - Anexo II) 


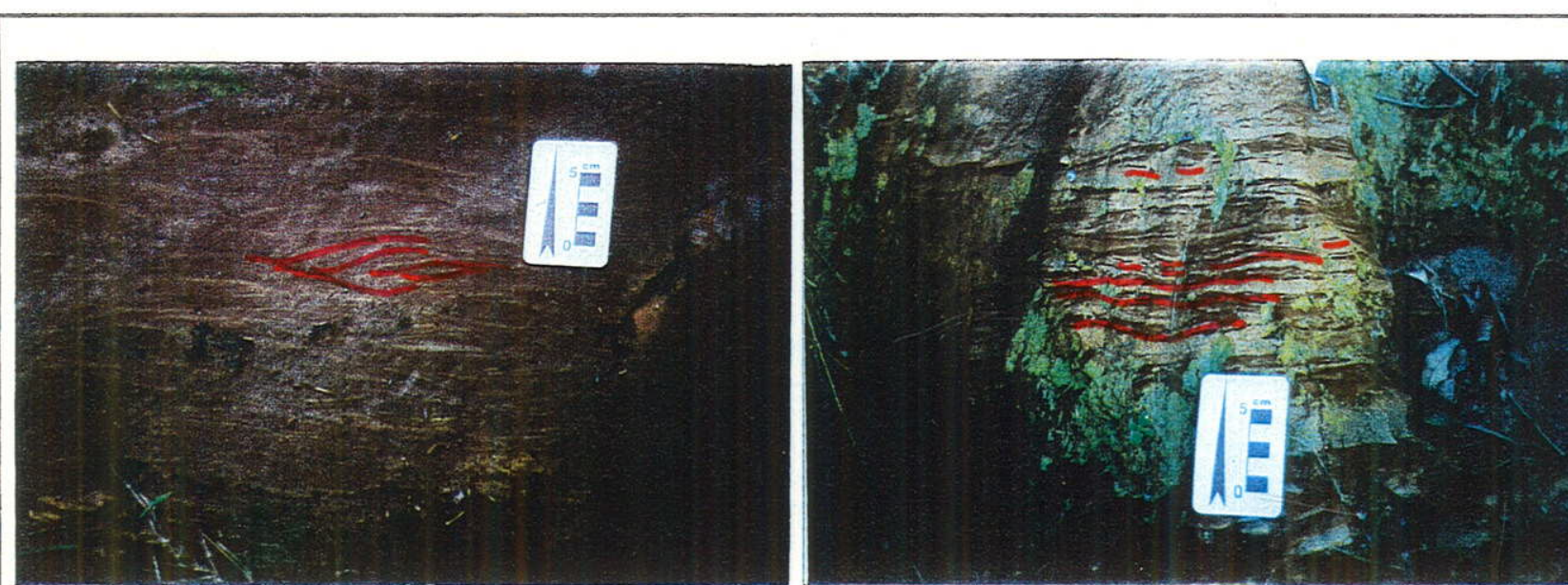

FOTO 3.11:Laminações cruzadas climbing e lenticu- FOTO 3.12: Laminações onduladas, wavy e flaser lares em ritmitos da Unidade Areno-Lamítica 1 da em ritmitos da Unidade Areno-Lamítica 1 da ForFormação Camarinha; seta indica topo de camada mação Camarinha (ponto S71a, localidade de Dom para norte; direção aparente de paleocorrente para Rodrigo, Área Sul - Anexo II)

oeste (esquerda da foto) (ponto S71a, localidade de

Dom Rodrigo, Área Sul - Anexo II)

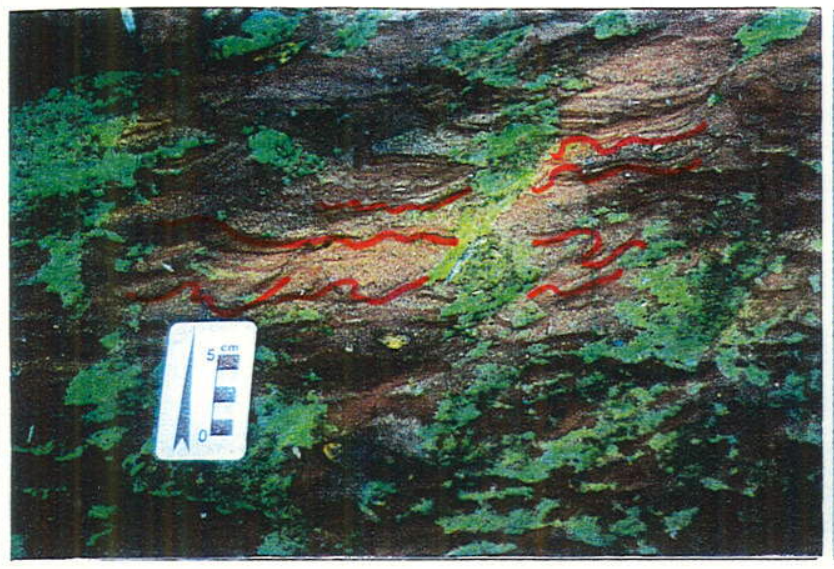

FOTO 3.14: Laminacões convolutas em ritmitos da

Unidade Areno-Lamítica 1 da Formação Camarinha

(ponto S71a, localidade de D. Rodrigo, Área Sul -

Anexo II)

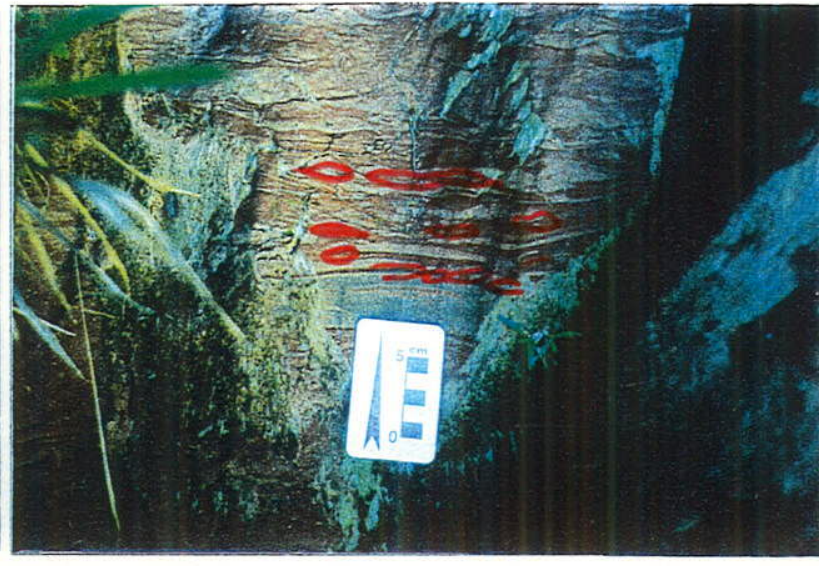

FOTO 3.15: Laminacões lenticulares e estruturas de escape de água em ritmitos da Unidade ArenoLamítica 1 da Formação Camarinha (ponto S71a, localidade de Dom Rodrigo, Área Sul - Anexo II)

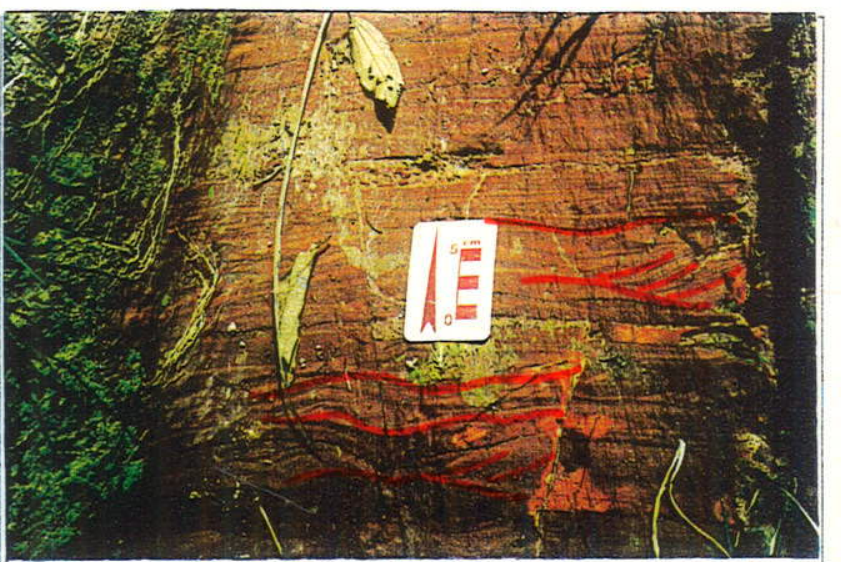

FOTO 3.13: Laminações paralela, ondulada assimétrica, cruzada tangencial e flaser em ritmitos da Unidade Areno-Lamítica I da Formação Camarinha; seta indica topo de camada para norte; direção aparente de paleocorrente para oeste (esquerda da foto) (ponto S151, localidade de Boqueirão, Área Sul - Anexo II)

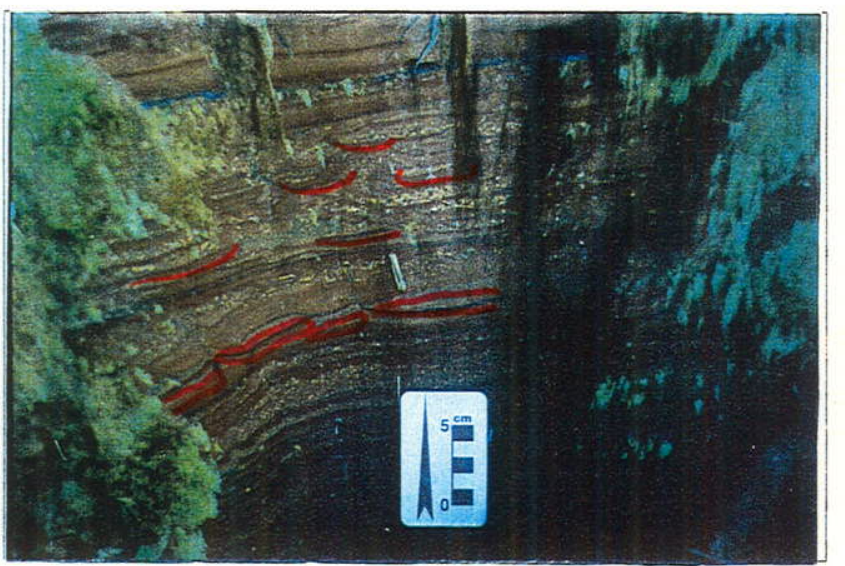

FOTO 3.16: Estruturas de escape de água em ritmitos da Unidade Areno-Lamítica 1 da Formação Camarinha (ponto S71a, localidade de Dom Rodrigo, Área Sul Anexo II) 
elevado grau de plasticidade dos sedimentos por ocasião da deposição dos níveis sucessivos e da atuação de possíveis esforços tectônicos sin-sedimentares.

As estruturas sedimentares são indicativas de topos de camadas para noroeste na faixa aflorante próximo ao limite sudeste da Área Sul, e para sudeste e sul nas lentes aflorantes próximo aos limites noroeste e norte da mesma área. Não foi possível visualizar as relações de topo e base nessa unidade na Área Norte, embora nesta região a mesma apresente mergulhos de camadas para sudeste. As estruturas cruzadas tangenciais e onduladas assimétricas indicam sentidos de paleocorrentes geralmente para oeste e mais raramente para leste, sendo este sentido muitas vezes aparente, devido à freqüente impossibilidade de visualização das estruturas em três dimensões. As medições que puderam ser efetuadas tiveram seus valores corrigidos do mergulho das camadas e seus resultados serão apresentados e analisados no Cap. 4 deste trabalho.

Em direção ao topo, ocorrem níveis arenosos progressivamente mais grossos a conglomeráticos, com espessura inicialmente centimétrica e passando a decimétrica e métrica à medida em que aumentam de freqüência na transição para a Unidade Conglomerática 2 (Fig.3.6d,e). Estes arenitos também são feldspáticos a líticos, micáceos, com grãos angulosos, subangulosos e subarredondados de quartzo, feldspato caulinizado, quartzito, filito, rochas carbonáticas, siltito e lamito. A seleção é mediana a ruim, e o cimento tem composição argilosa. Da base para o topo, ocorrem gradações normais, estratificações cruzadas tabulares e tangenciais indicando topos de camadas para noroeste e sentidos aparentes de paleocorrentes para oeste e mais raramente leste (Fotos 3.17 e 3.18), passando a paralela incipiente e finalmente estrutura maciça, culminando nas brechas e conglomerados intraformacionais polimíticos da Unidade Conglomerática 2 e caracterizando uma granocrescência das sucessões de sudeste para noroeste. Localmente, observamse superfícies erosivas no contato de níveis conglomeráticos sobrepostos a arenosos (Foto 3.19), e níveis arenosos com base erosiva e intraclastos síltico-argilosos sobrepostos a níveis lamíticos centimétricos (Foto 3.20).

\subsubsection{Unidade Conglomerática 2}

Aflora ao longo de toda a extensão da Área Sul, desde a localidade de Purunã até Bateias, e em uma faixa dobrada na forma de um sinclinal com fechamento para nordeste na Área Norte, entre as localidades de Prata, Santa Cruz e Itambezinho. Consiste em brechas e conglomerados polimíticos intraformacionais com intercalações arenosas grossas, basicamente de três tipos: maciços, com clastos de até $30 \mathrm{~cm}$ de tamanho e pobres em matriz (Foto 3.21); maciços a incipientemente estratificados, com clastos de até $20 \mathrm{~cm}$ de tamanho e matriz arenosa grossa a conglomerática (Foto 3.22); e maciços a incipientemente estratificados, com clastos de até $10 \mathrm{~cm}$ de 


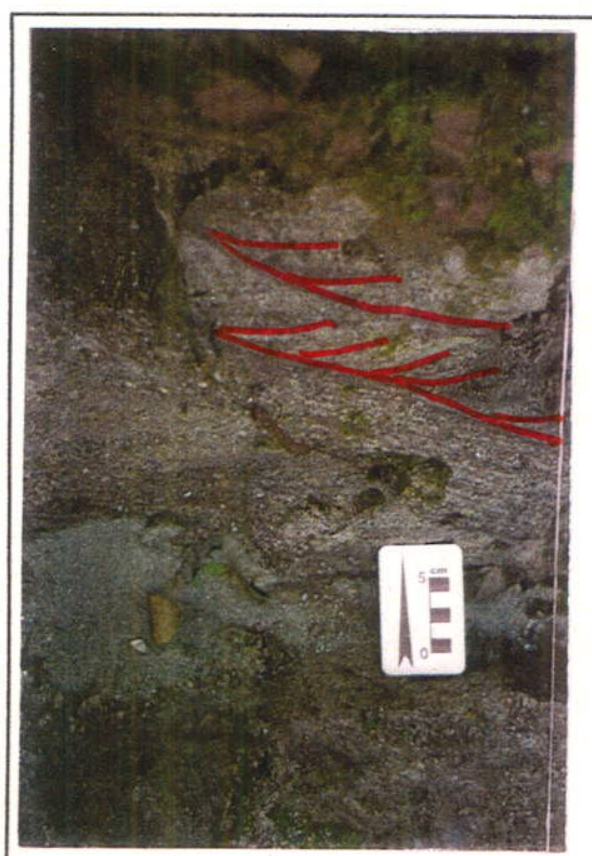

FOTO 3.17: Laminação cruzada tangencial em arenitos grossos da transição Unidade Areno-Lamítica 1 - Unidade Conglomerática 2 Formação Camarinha; seta indica topo de camada para norte; direção aparente de paleocorrente para oeste (esquerda da foto) (ponto S122, localidade de Felpudo, Area Sul Anexo II)

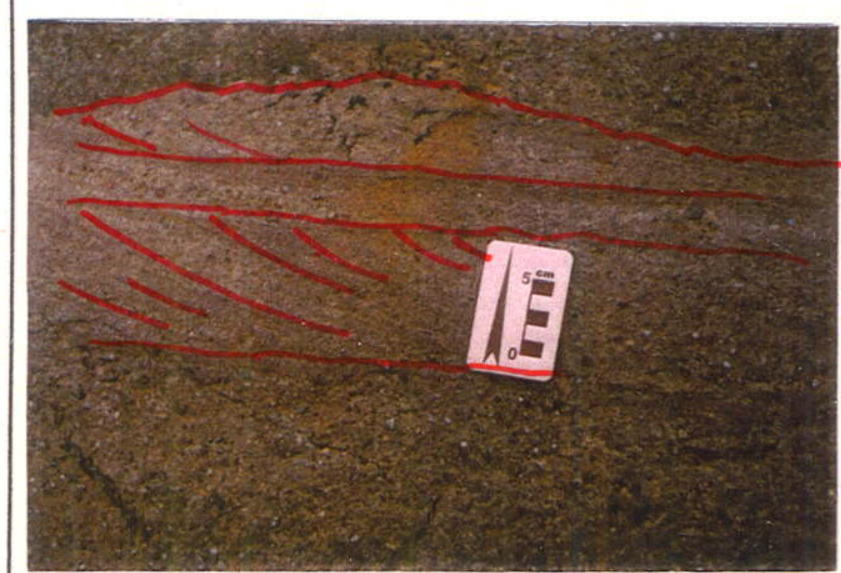

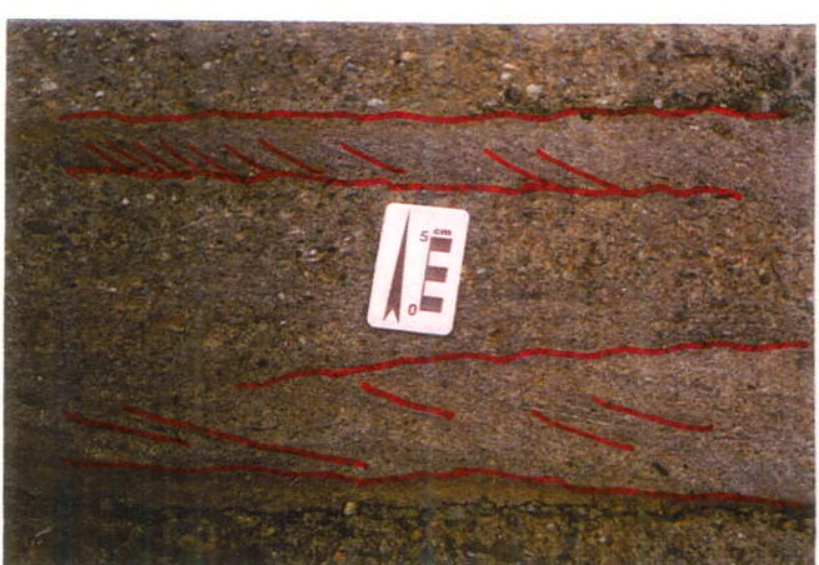

FOTO 3.18A

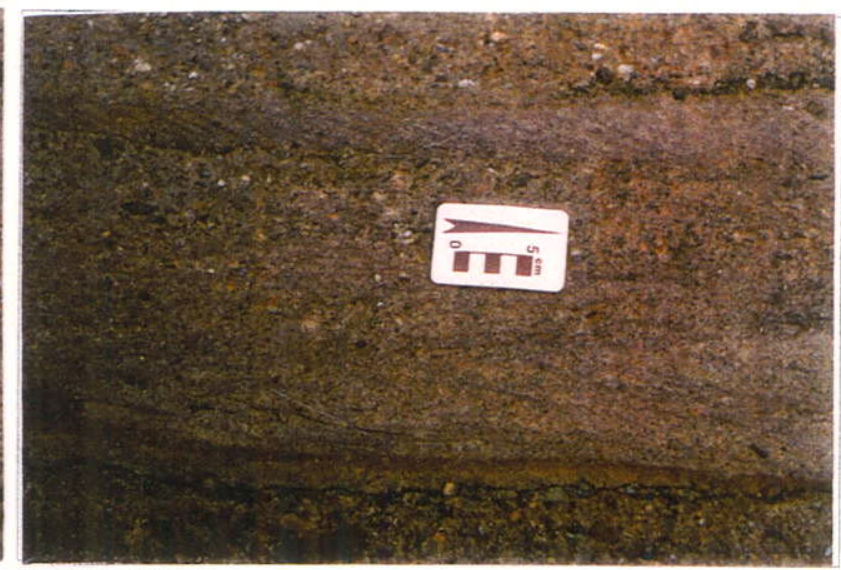

FOTO $3.18 \mathrm{~B}$

FOTO 3.18: Estratificações cruzadas tangenciais em arenitos grossos a conglomeráticos da transição Unidade Areno-Lamítica 1 - Unidade Conglomerática 2 da Formação Camarinha; seta indica topo de camada para norte (A) e direção aparente de paleocorrente para leste (B) (ponto S54, localidade de Onça, Anexo II)

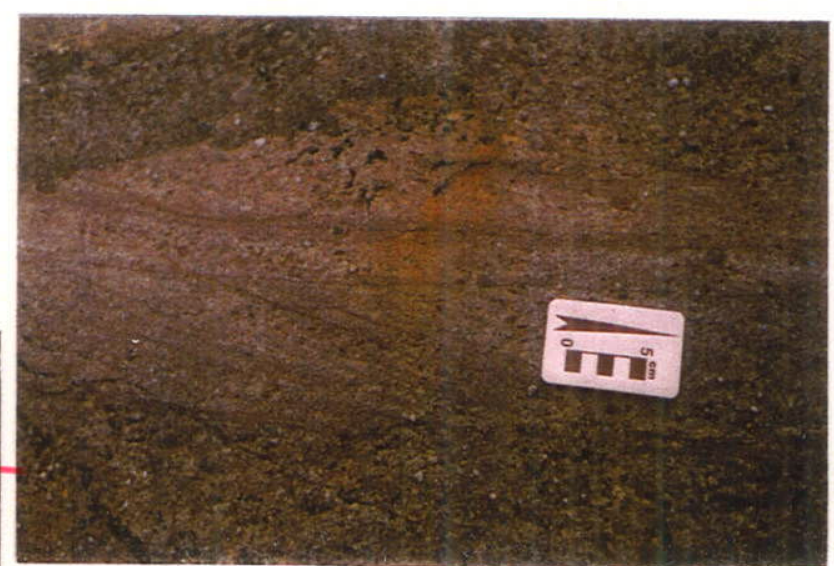

\section{FOTO 3.19B}

FOTO 3.19: Arenitos grossos a conglomeráticos da transição Unidade Areno-Lamítica 1 - Unidade Conglomerática 2 da Formacão Camarinha, com siva no topo do nível arenoso indicando topo de camada para norte (A) e direção aparente de paleocorrente para leste (B) (ponto S54, localidade de Onça, Área Sul - Anexo II)

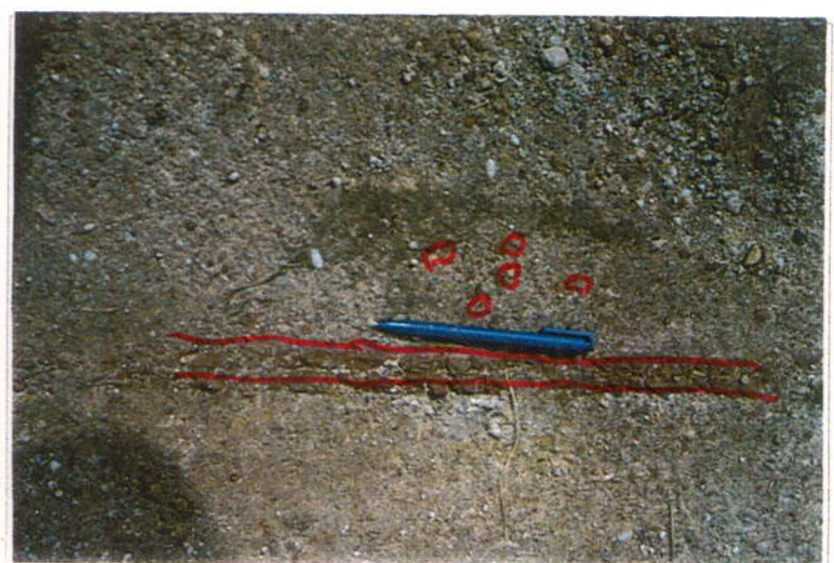

FOTO 3.20: Nível lamítico intercalado a arenitos grossos a conglomeráticos da transição Unidade Areno-Lamítica 1 - Unidade Conglomerática 2 da Formação Camarinha, com intraclastos de argila no nível arenoso superior (ponto S54, localidade de Onça, Área Sul - Anexo II) 
tamanho e matriz arenosa grossa a média (Fotos 3.23 e 3.24). Eventualmente, estas brechas e conglomerados podem apresentar imbricação local e incipiente de clastos.

Os clastos desses três tipos de brechas e conglomerados são geralmente angulosos a subangulosos. A composição é muito variada, consistindo em filitos, quartzitos, quartzo, rochas carbonáticas, xistos, rochas metabásicas, e de arenitos, siltitos e lamitos da Unidade Areno-Lamítica 1 (Fotos 3.21 a 3.24). Clastos de granitos são mais raros na Área Sul, porém abundantes na Área Norte (Foto 3.25), bem como clastos de rochas cálcio-silicáticas (Foto 3.26) e eventualmente clastos de rochas metavulcânicas alteradas, próximo à região do Complexo Granítico Três Córregos e dos limites com a Formação Água Clara.

A matriz das brechas e conglomerados, quando ocorre, é média a grossa e conglomerática, maciça a levemente estratificada, de seleção média a ruim e constituída por fragmentos angulosos, subangulosos e subarredondados de quartzo, feldspato caulinizado, filito, quartzito, rochas carbonáticas, xistos, arenitos e siltitos, com cimento argiloso e subordinadamente carbonático. Níveis arenosos médios a grossos e conglomeráticos, de espessura centimétrica a decimétrica, ocorrem intercalados às brechas e conglomerados, apresentando estrutura maciça a levemente estratificada, e localmente estratificações cruzadas tabulares e tangenciais.

As brechas e conglomerados desta unidade encontram-se freqüentemente truncados e com camadas verticalizadas próximo às zonas de falha, ocorrendo brechação e silicificação, além de intenso estiramento e achatamento de clastos nas imediações da Falha da Lancinha, com direcionamento de eixos C para NE. Uma análise da deformação destes seixos será apresentada no Cap. 5 deste trabalho.

Nas localidades de Bateias e Varzedo (Área Sul), observa-se uma granodecrescência das brechas e conglomerados em direção ao topo para NW, passando para arenitos conglomeráticos a grossos com estratificações cruzadas acanaladas (indicando topos de camadas para noroeste e sentidos de paleocorrentes para oeste e leste) e posteriormente médios, culminando nos arenitos finos, siltitos, lamitos e ritmitos da Unidade Areno-Lamítica 2.

\subsubsection{Unidade Areno-Lamítica 2}

$\mathrm{Na}$ Área Sul, aflora em pequenas lentes intercaladas à Unidade Conglomerática 2 nas localidades de Taquaral, Varzedo e Onça. Nesta área, consiste em arenitos finos que gradam e intercalam-se a siltitos, lamitos e ritmitos. Na Área Norte, ocorre em uma faixa mais larga, dobrada na forma de um sinclinal com fechamento para nordeste, abrangendo as regiões de parte do Rio Açungui, Rio da Prata e Arroio Santana. Nesta área ocorrem arenitos médios com lentes centimétricas de arenito grosso a conglomerático, gradando para arenitos finos, siltitos, lamitos e 


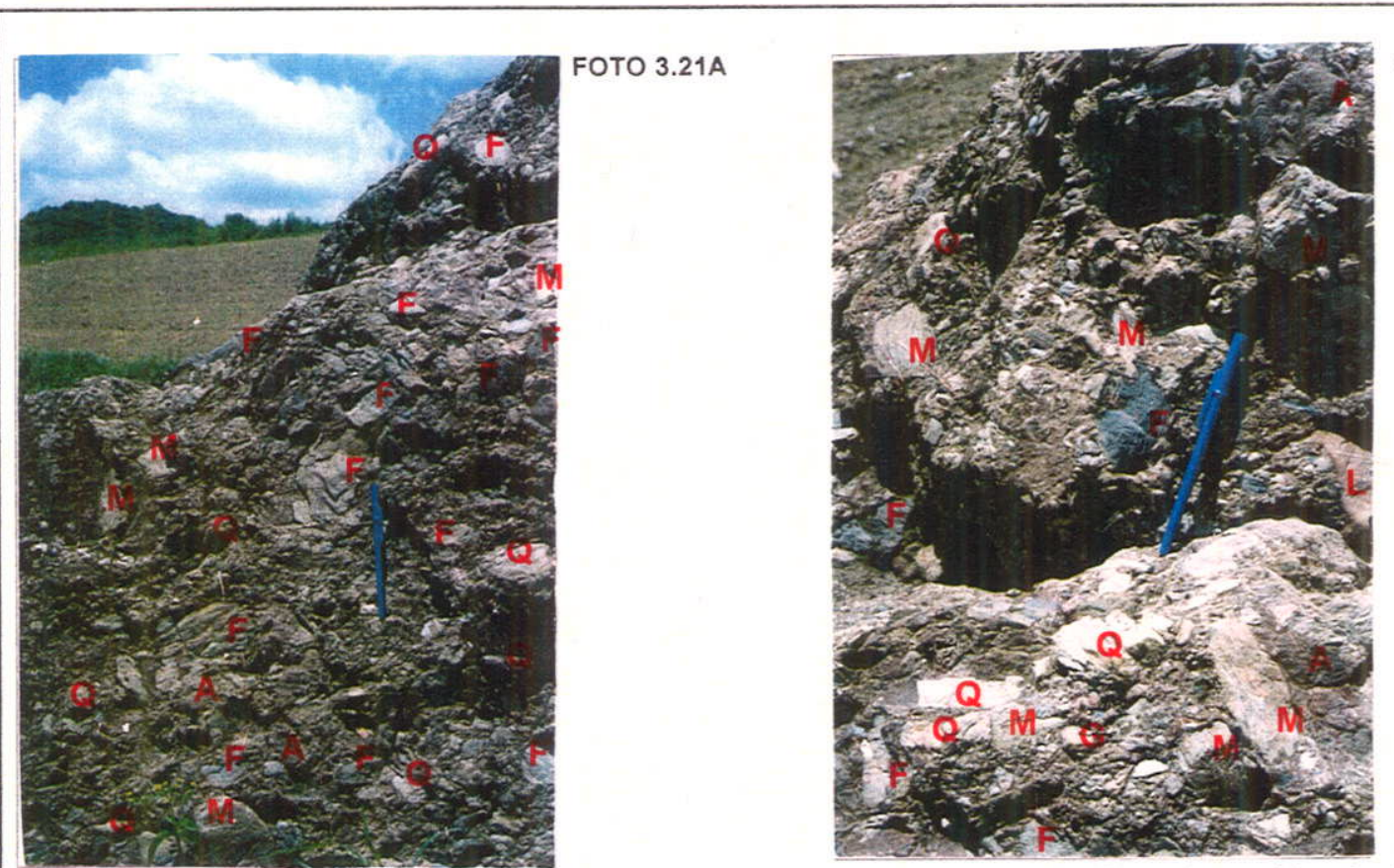

FOTO 3.21A,B: Brecha intraformacional polimítica maciça da Unidade Conglomerática 2 da Formação Camarinha (ponto S72, localidade de Varzedo, Área Sul - Anexo II)
FOTO $3.21 \mathrm{~B}$

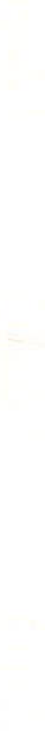

1200

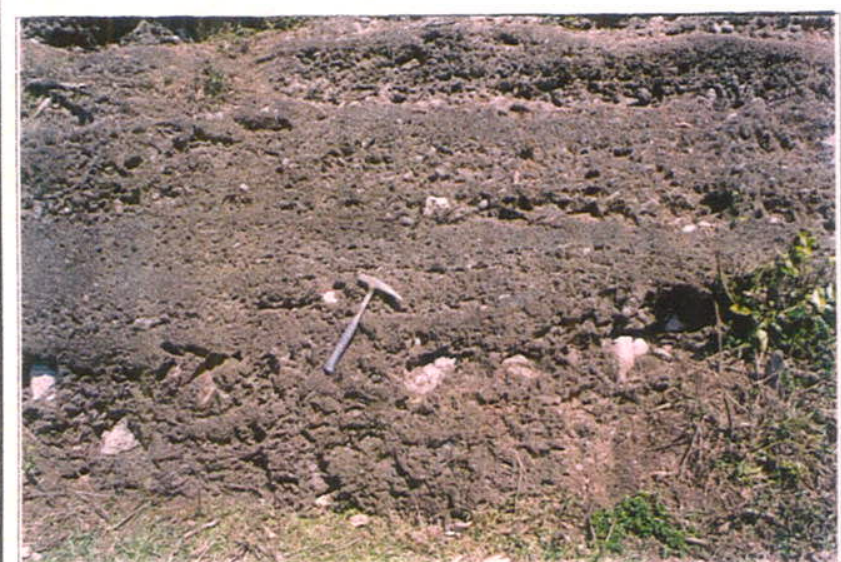

\section{FОTО $3.22 \mathrm{~B}$}

FOTO 3.22B: Brecha intraformacional polimítica estratificada da Unidade Conglomerática 2 da Formação Camarinha (ponto S159, localidade de Purunã, Área Sul - Anexo II)

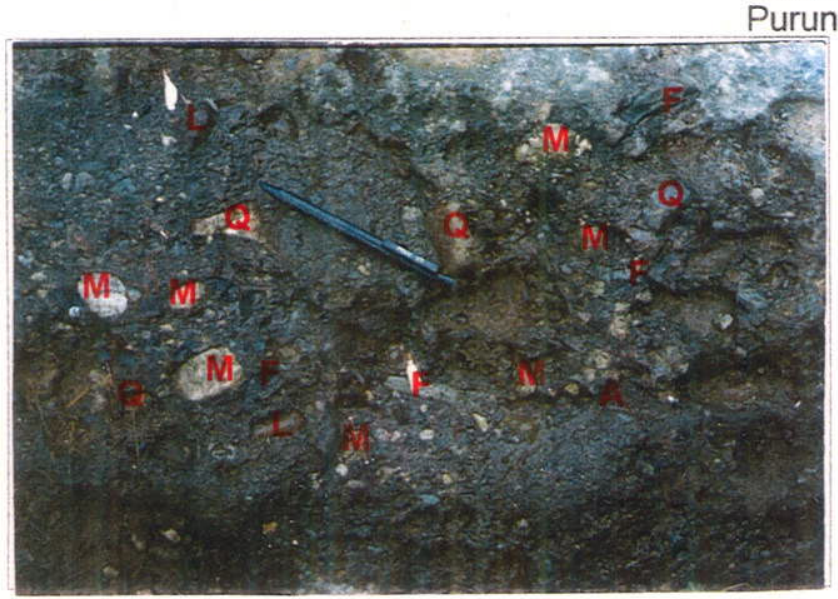

\section{LEGENDA:}

F : Filito da Formação Capiru

Q: Quartzo e quartzito

M:Rochas carbonáticas (mármores)

G: Granito

A:Arenito (intraclasto da Formação Camarinha)

$L$ : Lamito/siltito (intraclasto da Formação Camarinha)

FOTO 3.23: Brecha intraformacional polimítica maciça a incipientemente estratificada da Unidade Conglomerática 2 da Formação Camarinha

(ponto S29, localidade de Camarinha, Área Sul - Anexo II) 


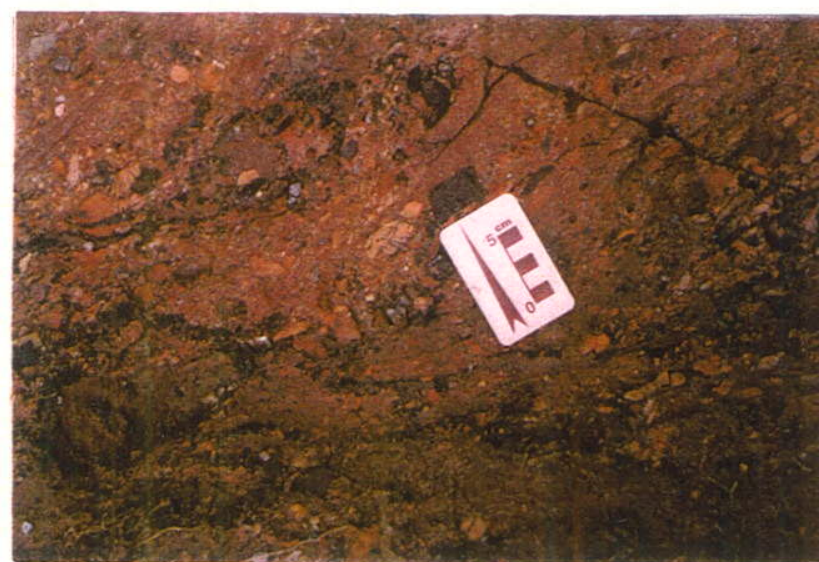

FOTO 3.24A

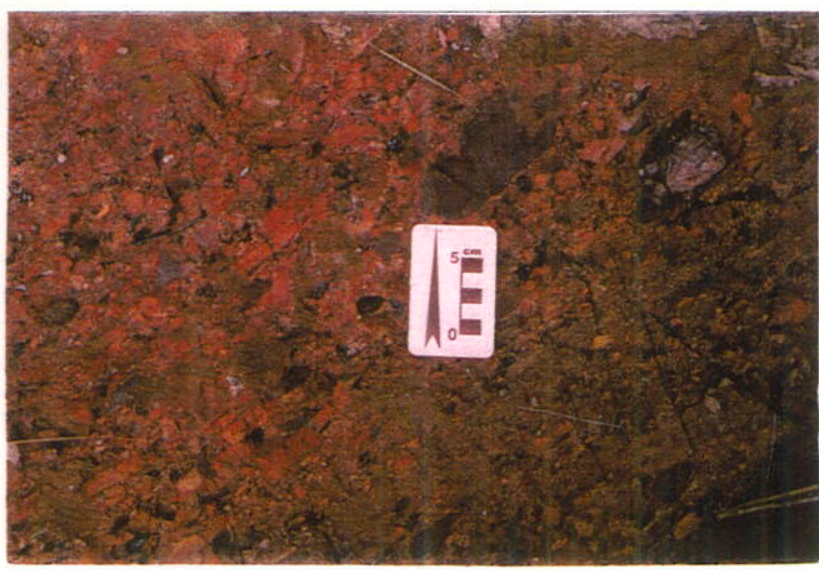

FOTO 3.24B

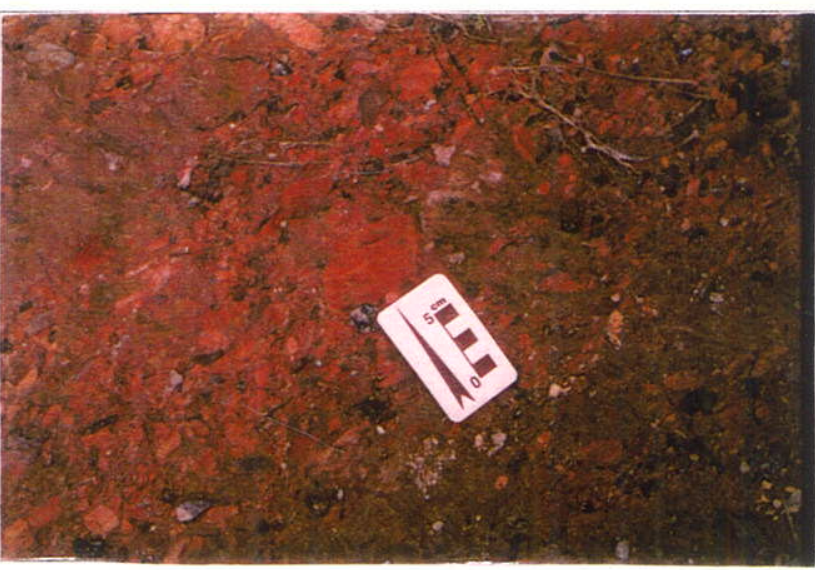

FOTO 3.24C:

FOTO 3.24A,B,C: Brecha intraformacional polimítica estratificada da Unidade Conglomerática 2 da Formação Camarinha; seta indica clastos de arenito (A,B) e lamito (C) provenientes da Unidade Areno-Lamítica 1 (ponto S74, localidades de Varzedo-Felpudo, Área Sul - Anexo II)

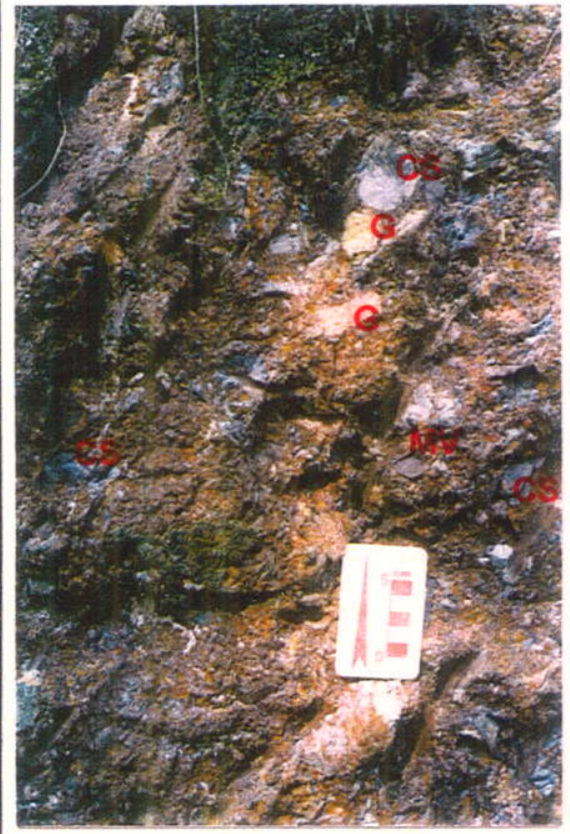

FOTO $3.25 \mathrm{~A}$

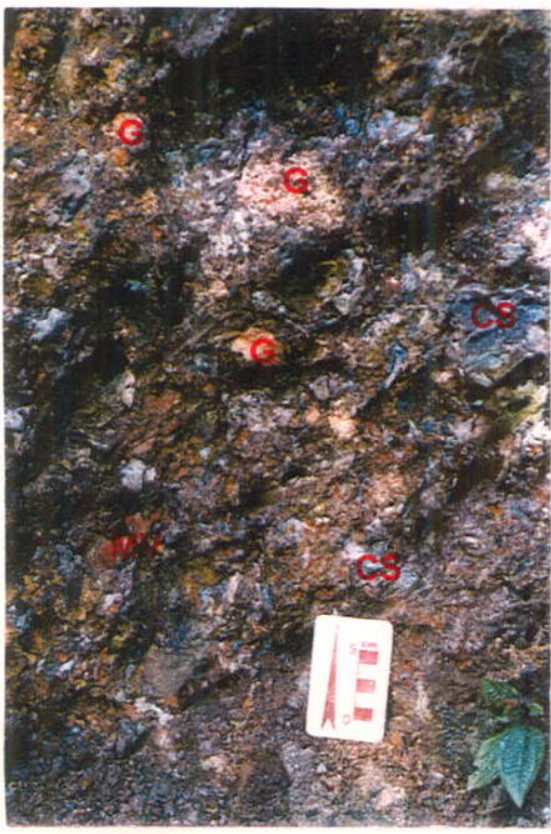

FOTO $3.25 \mathrm{~B}$

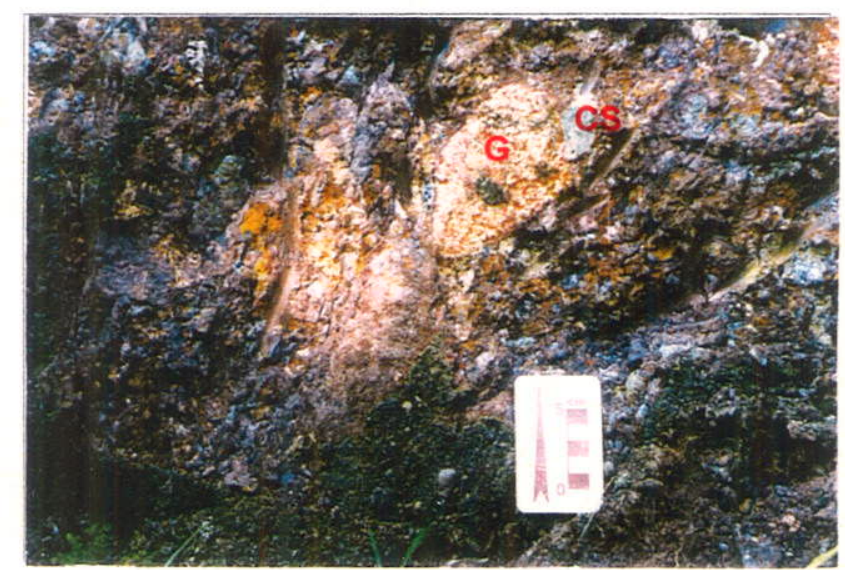

FOTO $3.25 \mathrm{C}$

FOTO 3.25A,B,C: Clastos de rochas graníticas (G), cálcio-silicáticas (CS) e metavulcânicas (MV) em conglomerados da Unidade Conglomerática 2 da Formação Camarinha (ponto N46, localidade de Rio dos Matos, Area Norte - Anexo III) 
ritmitos. Diferencia-se da Unidade Areno-Lamítica 1 por encontrar-se em situação distal com relação à Unidade Conglomerática 2 , de acordo com dados concordantes de mergulho e relações de topo e base de camadas, além de granodecrescência observada ao longo de afloramentos em perfis de campo.

Também nesta unidade os arenitos são feldspáticos a líticos e micáceos, com seleção média a ruim e grãos angulosos, subangulosos e subarredondados de quartzo, feldspato caulinizado, filito, quartzito, rochas carbonáticas, arenitos, siltitos e xistos, com pouca matriz e cimento argiloso e carbonático. Podem ser maciços a incipientemente estratificados, ocorrendo também estratificações cruzadas tabular, acanalada e localmente tangencial. Na Área Norte, ocorrem estratificações onduladas simétricas e assimétricas (Foto 3.27), indicando topos de camadas para sul e sentidos de paleocorrentes tanto para oeste como leste.

Os siltitos, lamitos e ritmitos, tanto na Área Sul como na Área Norte, mostram laminações paralelas, onduladas simétricas a raramente assimétricas, wavy, flaser, lenticular (Fotos 3.28 e 3.29), cruzadas tabulares, tangenciais e climbings, e estruturas deformacionais como convolutas, flames e pseudonódulos de areia, indicando topos de camadas para noroeste e sentidos aparentes de paleocorrentes para oeste e mais raramente leste.

Foi levantada em campo a possibilidade de que a Unidade Areno-Lamítica 2 poderia constituir um flanco afforante ou faixa destacada por falhas da Unidade Areno-Lamítica 1, e não uma unidade distinta. Esta possibilidade não foi comprovada, pois verificou-se que os mergulhos e as relações de topo e base das camadas da Unidade Areno-Lamítica 2 mostram-se concordantes com a Unidade Conglomerática 2 sotoposta, além de ter sido observada uma transição entre ambas próximo às localidades de Bateias e Varzedo (nordeste da Área Sul).

O contato entre as lentes da Unidade Areno-Lamítica 2 na Área Sul e os conglomerados e brechas que ocorrem a noroeste das mesmas (cartografados como pertencentes à Unidade Conglomerática 2) não se encontram bem definidos, por não estarem aflorantes e mostrarem-se freqüentemente truncados por falhas. Assim, não se pôde verificar se esses conglomerados e brechas poderiam constituir uma terceira unidade conglomerática sobreposta à Unidade ArenoLamítica 2. Além disso, mergulhos de camadas desses conglomerados e brechas para SE na região de Bateias (nordeste da Área Sul) sugerem que os mesmos podem constituir um flanco de sinclinal aflorante da própria Unidade Conglomerática 2, conforme exposto no Mapa Geológico e na Seção Geológica $\mathrm{CC}^{\dagger}$ (Anexo I).

$\mathrm{Na}$ porção noroeste da Área Norte, uma medida de acamamento com mergulho para NE ( $32^{\circ} \mathrm{W} / 14^{\circ} \mathrm{NE}$ ) em arenitos da Unidade Areno-Lamítica 1 (Mapa Geológico, Anexo I) poderia significar o início do fechamento de outro sinclinal na região, situação em que os sedimentos da 

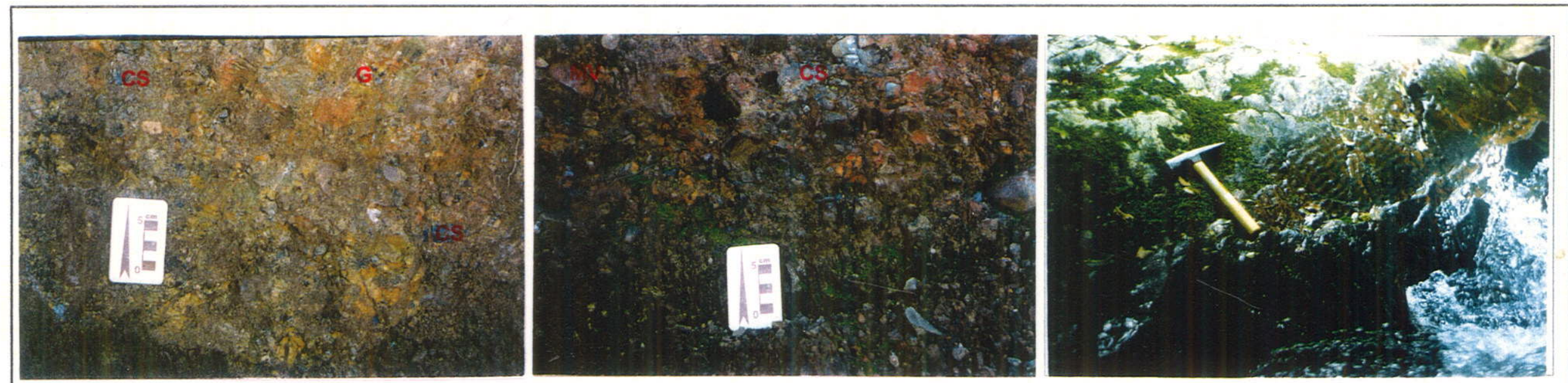

FOTO $3.26 \mathrm{~A}$

FOTO $3.26 \mathrm{~B}$

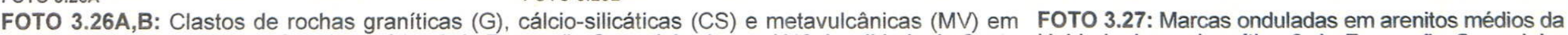
conglomerados da Unidade Conglomerática 2 da Formação Camarinha (ponto N42, localidade de Santa Cruz, Área Norte - Anexo III)

(ponto N51, Riono-Lamítica 2 da Formação Camarinha
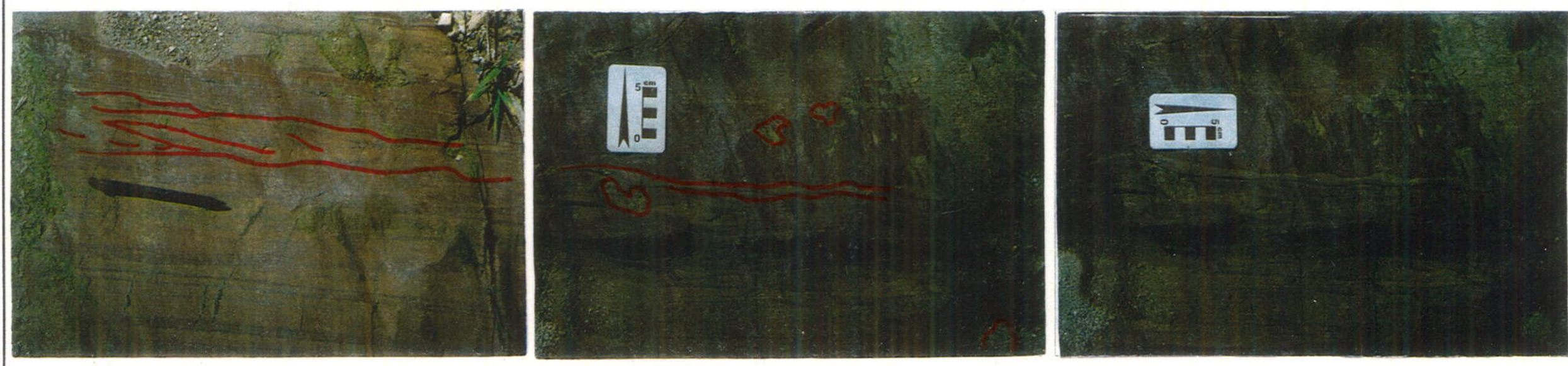

FOTO 3.29A

FOTO $3.29 \mathrm{~B}$

FOTO 3.28: Laminacões ondulada assimétrica, FOTO 3.29: Laminacões ondulada assimétrica, wavy, lenticular e pseudonódulos de areia em ritmitos da wavy flaser e cruzada tangencial em ritmitos da Unidade Areno-Lamítica 2 da Formação Camarinha; seta indica topo de camada para norte (A) e direção Unidade Areno-Lamítica 2 da Formação Camarinha, aparente de paleocorrente para leste (B) (ponto S130, localidade de Varzedo, Área Sul - Anexo II) indicando topo de camada para norte (alto da foto)

e direção aparente de paleocorrente para leste

(direita da foto) (ponto S130, localidade de Varzedo,

Area Sul - Anexo II) 
referida unidade estariam sobrepostos e não sotopostos à Unidade Conglomerática 2. Neste caso, na Área Norte não haveria ocorrência da Unidade Areno-Lamítica 1 conforme considerado neste trabalho, e sim apenas da Unidade Areno-Lamítica 2, sobreposta aos conglomerados e brechas da Unidade Conglomerática 2. Entretanto, tal hipótese necessita de melhor confirmação, uma vez que baseia-se em uma única medida de acamamento, efetuada próximo a uma zona de falhas, não tendo sido encontradas outras medidas de acamamento que possam confirmá-la.

\subsection{PETROGRAFIA}

\subsubsection{Observações}

Foram confeccionadas 22 lâminas petrográficas de rochas das unidades Areno-Lamítica 1, Conglomerática 2 e Areno-Lamítica 2, visando um detalhamento de suas características composicionais e texturais, bem como a classificação modal dos arenitos e análise de sua proveniência. O número reduzido de lâminas confeccionadas deve-se à freqüência e intensidade do grau de alteração intempérica dos sedimentos da Formação Camarinha em geral.

Conforme exposto anteriormente, este elevado grau de alteração intempérica impediu a confecção de lâmina delgadas para um estudo mais detalhado das rochas constituintes da Unidade Conglomerática 1. A Unidade Areno-Lamítica 1 teve oito lâminas preparadas, provenientes dos pontos S11 (localidade de Taquaral), S60 (localidade de Felpudo), S102 e S104 (localidade de Boqueirão), todos na Área Sul (Anexo l). A Unidade Conglomerática 2 teve doze lâminas preparadas, provenientes dos pontos S29 (localidade de Camarinha), S54 (localidade de Onça), S62, S65 e S68 (localidade de Felpudo), S72 (localidade de Varzedo), S89 (localidade de D. Rodrigo), S139 (localidade de Retiro Grande), S159 e S160 (localidade de Purunã), também na Área Sul (Anexo II). Não foram obtidas boas amostras para confecção de lâminas petrográficas destas unidades na Área Norte. Já a Unidade Areno-Lamítica 2 teve uma lâmina preparada proveniente da Área Sul (ponto S142, localidade de Onça, Anexo II) e uma lâmina preparada proveniente da Área Norte (ponto N51, rio da Prata, Anexo III). Também não foram obtidas boas amostras para confeç̧ão de um maior número de lâminas petrográficas desta última unidade.

As lâminas dos pontos S11, S60, S104, S68(b), S142 e N51, representando arenitos melhor preservados que ocorrem nas três unidades analisadas, foram submetidas a uma contagem modal de 1000 pontos de arcabouço cada uma, em uma malha de $0,3 \times 0,3 \mathrm{~mm}$. Suas proporções de quartzo mais fragmentos líticos quartzosos (quartzito, chert), feldspatos e fragmentos líticos instáveis foram recalculadas em relação a 100\%, para efeito de classificação nos diagramas QFP de Dott (1964) e 
Pettijohn et al. (1987). Como a quantidade de matriz observada não chega a $10 \%$, optou-se pelo uso dos ramos "Arenitos" destes diagramas.

Assim, conforme os referidos diagramas (Fig.3.7), verifica-se que os arenitos da Formação Camarinha podem ser classificados como arenitos feldspáticos (feldspato-arenitos) segundo Dott (1964), com exceção da amostra S60, classificada como arenito feldspático a lítico, ou como arenitos arcosianos a arcóseos segundo Pettijohn et al. (1987), com exceção também da amostra S60, no limite entre arenitos arcosianos, arenitos líticos, subarcóseos e sublitarenitos. Embora a classificação de Pettijohn et al. (1987) seja mais recente, considera-se para este trabalho a de Dott (1964) mais clara quanto a seus critérios e limites entre os diferentes tipos.

Chama a atenção o fato de esses arenitos situarem-se predominantemente no campo de arenitos feldspáticos ou arcosianos, uma vez que, tanto em escala macroscópica como em parte na escala microscópica, seu aspecto à primeira vista leva à impressão de tratarem-se de arenitos predominantemente líticos. Entretanto, uma vez que foram confeccionadas poucas lâminas petrográficas das unidades da Formação Camarinha, é possível que este conjunto de lâminas aqui descritas não represente uma amostragem muito significativa dos sedimentos em questão. A impressão visual de predomínio de fragmentos líticos pode também ser mascarada pelo fato de muitos grãos aparentemente constituídos por rochas metassedimentares de granulação fina (filitos, metassiltitos) tratarem-se, na realidade, de feldspatos extremamente alterados hidrotermal e intempericamente para micas finas e argilominerais.

Convém ressaltar que, embora costumem ser mediamente a mal selecionados, os arenitos da Formação Camarinha apresentam variação granulométrica dentro do próprio arcabouço detrítico, sendo rara ou inexistente a ocorrência de protomatriz ou ortomatriz finas $(<30 \mu$, segundo critério estabelecido por Pettijohn et al., 1987). Eventualmente, pode ocorrer uma recristalização dessa matriz, constituindo uma epimatriz que confunde-se com o cimento presente. Igualmente restritas e localizadas são as ocorrências de pseudomatriz.

\subsubsection{Unidade Areno-Lamítica 1}

Em escala microscópica, os arenitos da Unidade Areno-Lamítica 1 apresentam grãos angulosos, subangulosos e subarredondados de tamanho submilimétrico a milimétrico, com contatos tangenciais, longitudinais e eventualmente côncavo-convexos quando em frações mais finas (Fotos 3.30 a 3.32, 3.34). Intercrescimentos autigênicos de quartzo raramente são visíveis, estando provavelmente mascarados ou confundindo-se com a angulosidade dos grãos. 

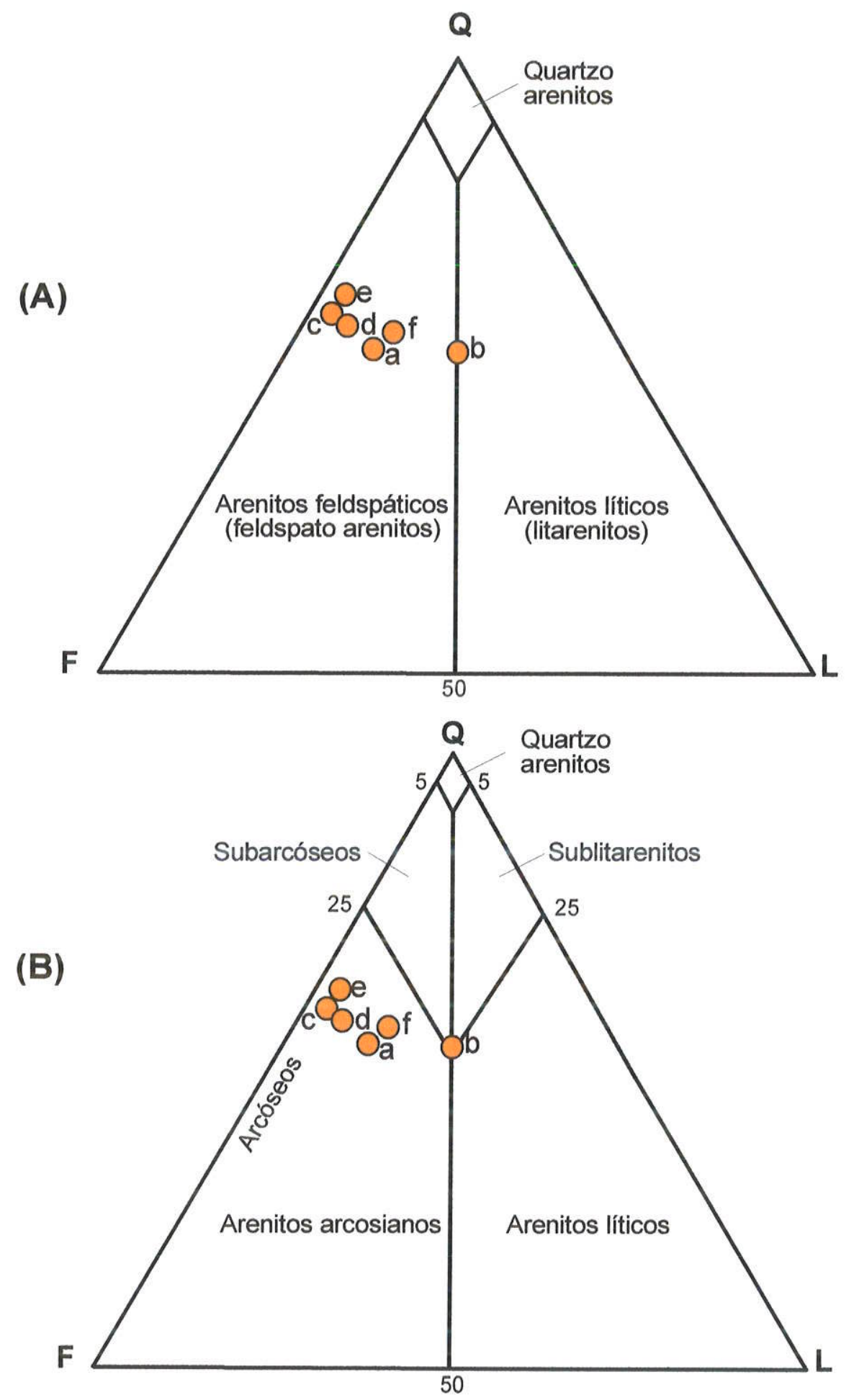

Fig.3.7: Diagramas QFL de Dott (1964) (A) e Pettijohn et al. (1987) (B) para classificação modal de arenitos, sendo:

$\mathrm{Q}$ - Quartzo e fragmentos líticos quartzosos (quartzitos, cherts)

F - Feldspatos

L - Fragmentos líticos instáveis

a - Ponto S11 (Unidade Areno-Lamítica 1, Área Sul, localidade de Taquaral)

b - Ponto S60 (Unidade Areno-Lamítica 1, Area Sul, localidade de Felpudo)

c - Ponto 104a (Unidade Areno-Lamímita 1, Area Sul, localidade de Boqueirão)

d - Ponto S68 (Unidade Conglomerática 2, Área Sul, localidade de Felpudo)

e - Ponto S142 (Unidade Areno-Lamítica 2, Área Sul, localidade de Onça)

f - Ponto N51 (Unidade Areno-Lamítica 2, Área Norte, localidade de Prata) 


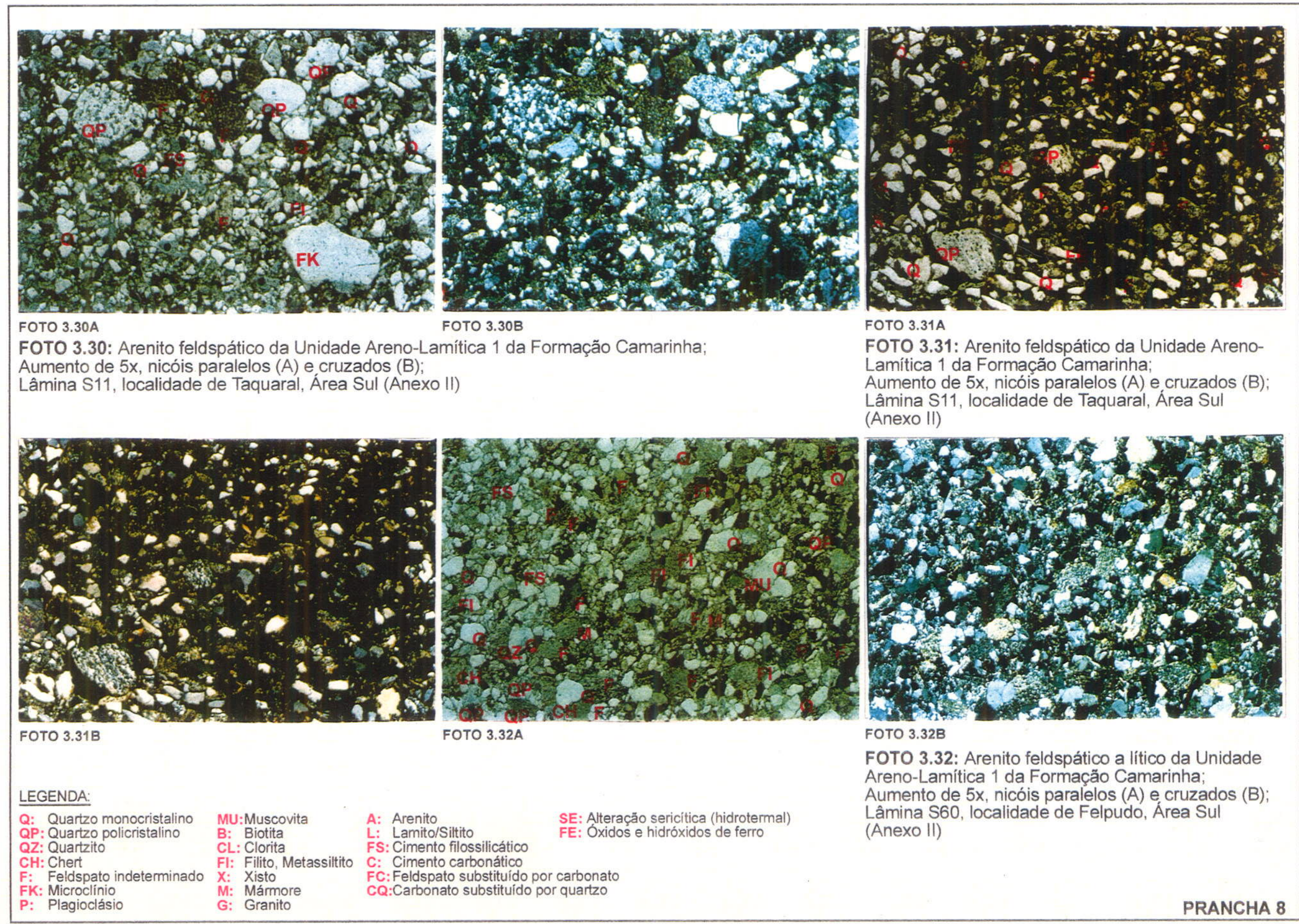


Mineralogicamente, ocorrem os seguintes componentes, que podem ser visualizados nas Fotos 3.30 a 3.34 :

- quartzo monocristalino (22 a 33\% de cada lâminas) com inclusões de vacúolos e agulhas de rutilo;

- quartzo policristalino com contatos suturados (2 a 9\%), mais raramente lisos (até 1,5\%), eventualmente estirados (até $1,5 \%$ );

- feldspatos intensamente alterados para micas finas e caulinita, formando uma mistura desses dois minerais que chega a substituir completamente o grão original, impedindo sua identificação quanto ao tipo (17 a 22\%); quando identificáveis, ocorrem feldspato potássico (microclínio, menos de $1 \%$ ) e plagioclásio (até $2,5 \%$ ) com geminação polissintética característica, porém também não identificável quanto ao tipo por falta de boas seções;

- micas detríticas, principalmente muscovita (2 a 4\%), disposta paralelamente à estratificação das rochas e freqüentemente deformada nos contatos por outros grãos; mais raramente, ocorrem biotita e clorita (menos de $1 \%$ );

- grãos detríticos provenientes de minerais acessórios, como epidoto (até 1,5\%), zircão (até 1\%) e turmalina (menos de 1\%); eventualmente, ocorrem resquícios de minerais ferromagnesianos prismáticos (hornblenda?), totalmente alterados e substituídos por óxidos e hidróxidos de ferro (menos de 1\%);

- minerais opacos (5 a 10\%), freqüentemente alterados e liberando hidróxidos de ferro que disseminam-se e tingem toda a lâmina, inclusive preenchendo fraturas (Foto 3.35).

- como fragmentos líticos, ocorrem grãos angulosos e subangulosos de quartzito micáceo (até $3 \%$ ), grãos subarredondados de cherts (até $2 \%$ ), grãos alongados de filitos e metassiltitos (até $15 \%$ ), eventualmente grãos de xistos (até $2,5 \%$, Foto 3.33 ), e mais raramente granitos e rochas metavulcânicas (menos de 1\%).

O cimento (10 a 15\%) normalmente é argiloso e ferruginoso, mais raramente quartzoso, evidenciado por misturas de argilominerais (possivelmente illita e caulinita) (Fotos 3.30 a 3.32 , 3.34), óxidos e hidróxidos de ferro intersticiais, e localmente intercrescimentos autigênicos mal definidos de quartzo. Os óxidos e hidróxidos de ferro (até 16\%) ocorrem também como alteração de minerais opacos e ferromagnesianos, disseminados pelas lâminas (Foto 3.35). Outras feições de alteração incluem caulinização dos feldspatos e sericitização disseminada por toda a lâmina, além de concentrada também nos feldspatos (Fotos 3.30 a $3.32,3.34,3.36$ ). As micas finas que constituem essa alteração sericítica não mostram qualquer orientação preferencial, às vezes também preenchendo fraturas nos grãos, o que leva a crer tratar-se de uma feição de alteração hidrotermal. 


\subsubsection{Unidade Conglomerática 2}

O grande tamanho a que podem chegar os clastos presentes na Unidade Conglomerática 2 (até 10-30 cm) fez com que fossem amostradas apenas porções mais finas das e conglomerados que a constituem, a fim de se verificar a composição de seus grânulos e clastos menores, bem como da fração grossa de sua matriz arenosa. Foi também amostrado um nível arenoso do ponto 68 (Localidade de Felpudo, Área Sul, Anexo II) intercalado às brechas e conglomerados, aqui tratado como um arenito feldspático segundo a classificação de Dott (Fig.3.7).

Os clastos maiores, de dimensões até $1 \mathrm{~cm}$, são angulosos e subarredondados e são constituídos por rochas carbonáticas, filitos, metassiltitos, quartzitos, xistos, cherts, e arenitos e siltitos da Unidade Areno-Lamítica 1 (Fotos 3.37 a 3.41). A matriz nem sempre é abundante, mostrando-se grossa, com seleção média a ruim e grãos angulosos a subarredondados com contatos tangenciais e longitudinais. Consiste em quartzo monocristalino ( $25 \%$ da matriz), quartzo policristalino com contatos suturados $(5 \%)$ ou estirados $(1 \%)$, feldspatos alterados para caulinita e micas finas (20\%), muscovita detrítica (3\%), eventualmente biotita e clorita detríticas (menos de $1 \%)$, minerais opacos $(3 \%)$, e fragmentos de filitos $(4 \%)$, bem como de arenitos $(2 \%)$ e siltitos $(2 \%)$ provenientes da Unidade Areno-Lamítica 1.

O cimento é predominantemente carbonático, com intercrescimento poiquilotópico e substituição de feldspatos, podendo também mostrar-se eventualmente substituído por quartzo (Fotos 3.37, 3.38, 3.40, 3.41). Subordinadamente ocorre cimento argiloso e ferruginoso, na forma de minerais argilosos (illita?) e óxidos e hidróxidos de ferro preenchendo interstícios.

Nas amostras coletadas próximo à zona da Falha da Lancinha (S54, localidade de Onça; S2 e S65, localidade de Felpudo; S89, localidade de D. Rodrigo; e S139, localidade de Retiro Grande Área Sul, Anexo II), as rochas mostram fraturamento e brechação, com feições de hidrotermalismo associadas na forma de sericitização disseminada e preenchendo fraturas, juntamente com recristalização de carbonatos e quartzo drusiforme (Fotos 3.42 e 3.43).

Os arenitos médios a grossos intercalados às brechas e conglomerados desta unidade são mediamente a mal selecionados, apresentando grãos angulosos a subangulosos com contatos tangenciais (eventualmente longitudinais e côncavo-convexos). São constituídos por quartzo monocristalino (28\%), policristalino com contatos lisos (1-2\%) e suturados $(4,5 \%)$, feldspato alterado para micas finas e caulinita $(20 \%)$, eventualmente identificados como microclínio e plagioclásio (4\%), muscovita detrítica (4\%), biotita e clorita detríticas (menos de 1\%), grãos provenientes de minerais acessórios (menos de $1 \%$ de turmalina, epidoto, zircão, hornblenda alterada para biotita e hidróxidos de ferro, e até $4 \%$ de minerais opacos). Como fragmentos líticos, 


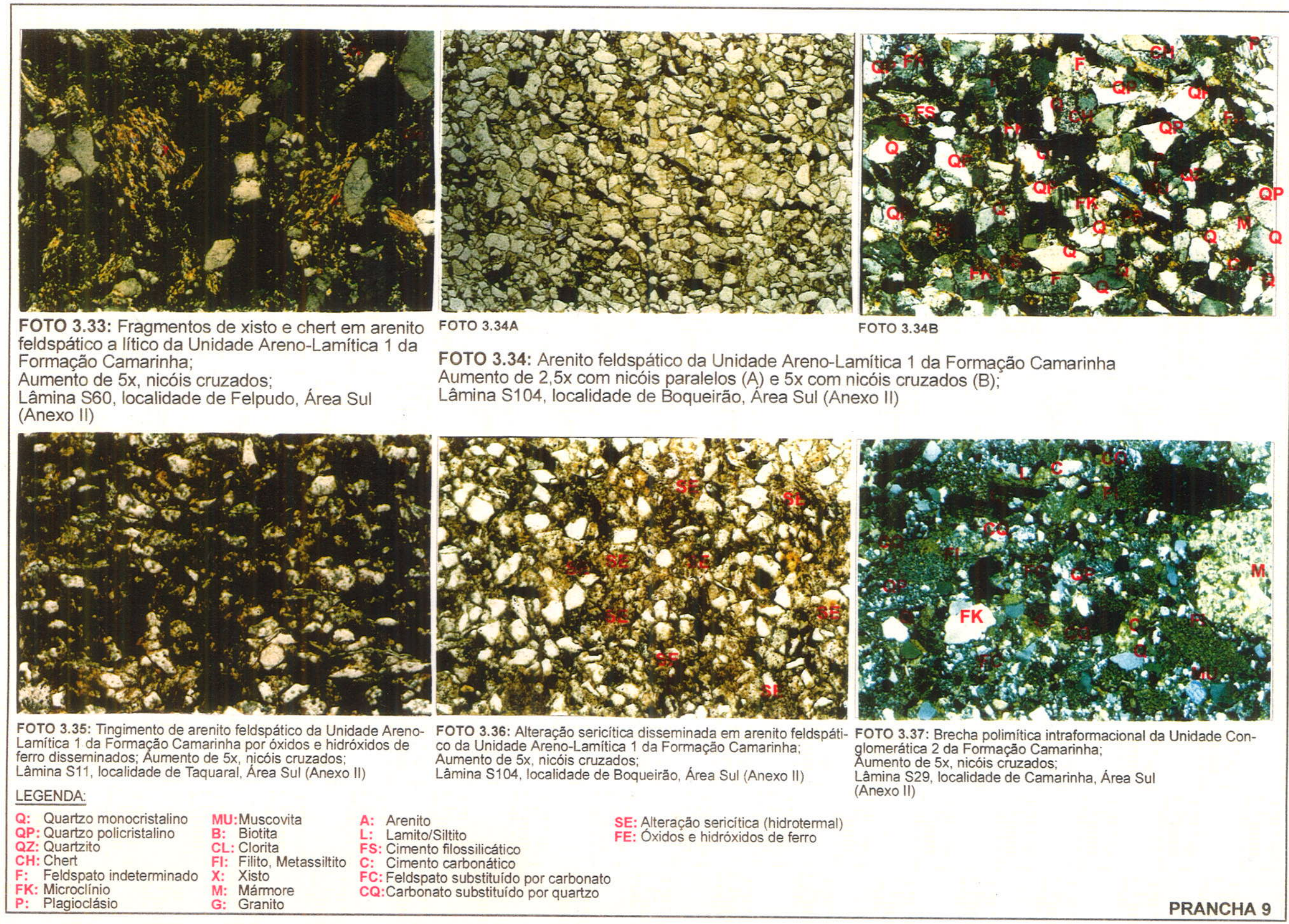




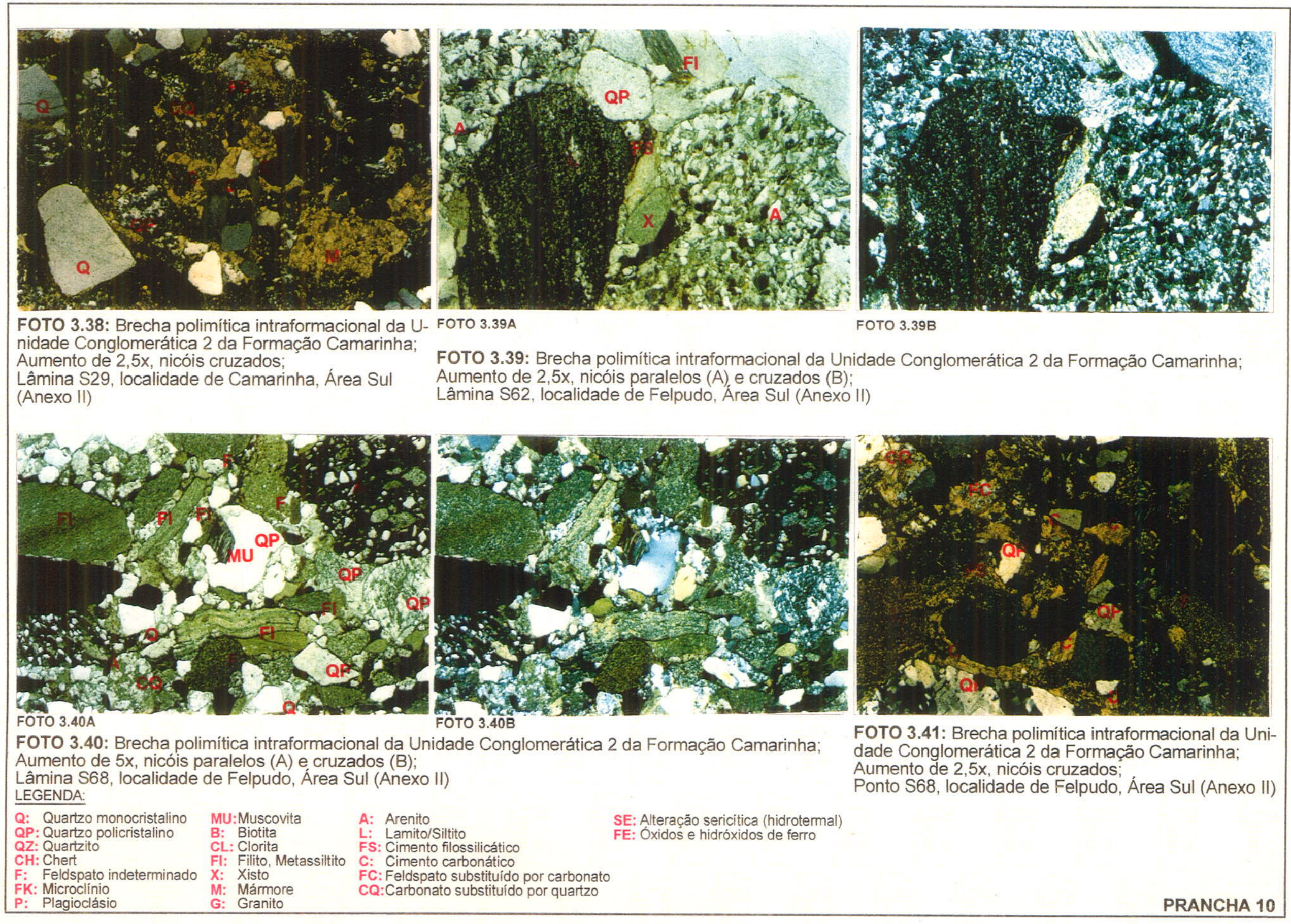


ocorrem quartzito e chert (até 1\%), além de filitos (5\%) e subordinadamente xisto, rochas metavulcânicas e granitos (até 1\%, Fotos 3.44 e 3.45).

O cimento (até 20\%) também é predominantemente carbonático, com recristalização poiquilotópica e substituição de feldspatos. Subordinadamente, ocorrem também cimento argiloso e ferruginoso, raramente quartzoso. As ocorrências próximas à Falha da Lancinha também se encontram brechadas e fraturadas, com sericitização disseminada pela lâmina e preenchendo fraturas, caracterizando uma alteração hidrotermal.

\subsubsection{Unidade Areno-Lamítica 2}

Tanto na Área Sul como na Área Norte, os arenitos médios desta unidade também são mediamente a mal selecionados, com contatos tangenciais a longitudinais (eventualmente côncavoconvexos) entre grãos angulosos e subangulosos. São constituídos por quartzo monocristalino (20 a $27 \%$ ), policristalino com contatos suturados ( 10 a $20 \%$ ), mais raramente lisos e em cristais estirados (menos de 1\%), feldspato alterado para caulinita e micas finas (16 a 21\%), eventualmente identificado como microclínio e plagioclásio (até $3 \%$ cada um), muscovita e biotita detríticas (até $1,5 \%$ ), epidoto, zircão e hornblenda detríticos (até $2 \%$ ), minerais opacos (2\%), e fragmentos de quartzito (até 1,5\%), chert (menos de $1 \%$ ), filito (2\%) e mais raramente xisto (menos de $1 \%$ ), granito (2\%, Foto 3.46$)$ e rochas metavulcânicas (até 1,5\%). Fragmentos de rochas carbonáticas (até 4\%) são mais comuns na Área Norte.

O cimento predominante é argiloso (8\%) na Área Sul, e predominantemente carbonático (7\%) na Área Norte, com intercrescimento poiquilotópicos nos interstícios. Subordinadamente, ocorre também como cimento ferruginoso e quartzoso com intercrescimento drusiforme. A alteração é tanto intempérica, na forma de óxidos e hidróxidos de ferro (até 14\%) disseminados, preenchendo fraturas e substituindo minerais ferromagnesianos, como também hidrotermal (até 20\%, mais evidente na Área Sul), na forma de sericitização evidenciada por micas finas (disseminadas e preenchendo fraturas) e quartzo drusiforme (também preenchendo fraturas) (Foto 3.47).

\subsection{DIFRATOMETRIA DE RAIOS-X}

A granulometria muito fina dos siltitos, ritmitos e lamitos da Formação Camarinha impede sua análise petrográfica em escala de lâmina delgada, tendo-se então optado por um análise de Difratometria de Raios- $X$ da fração fina $(<2 \mu)$ desses sedimentos, visando uma determinação 


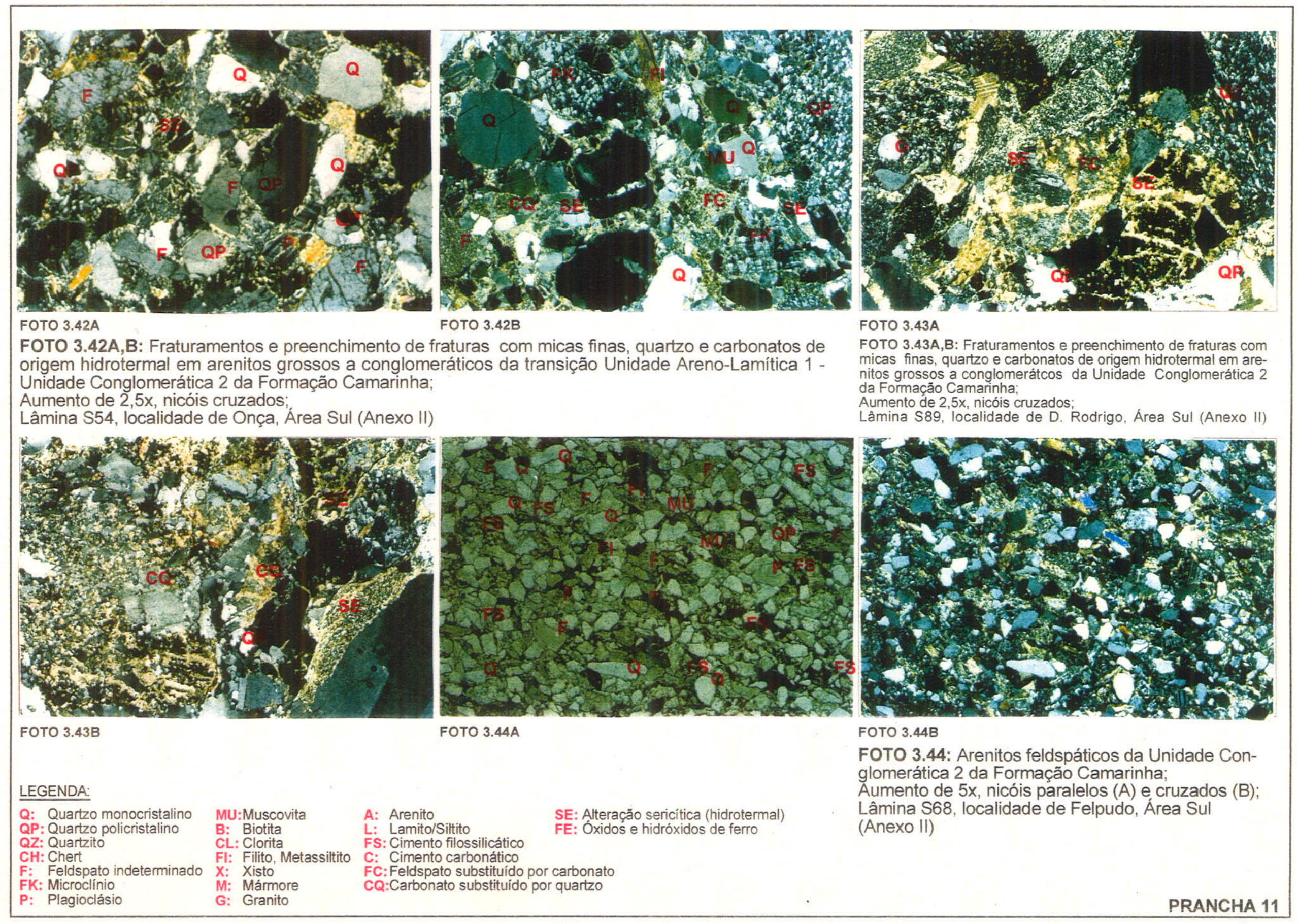




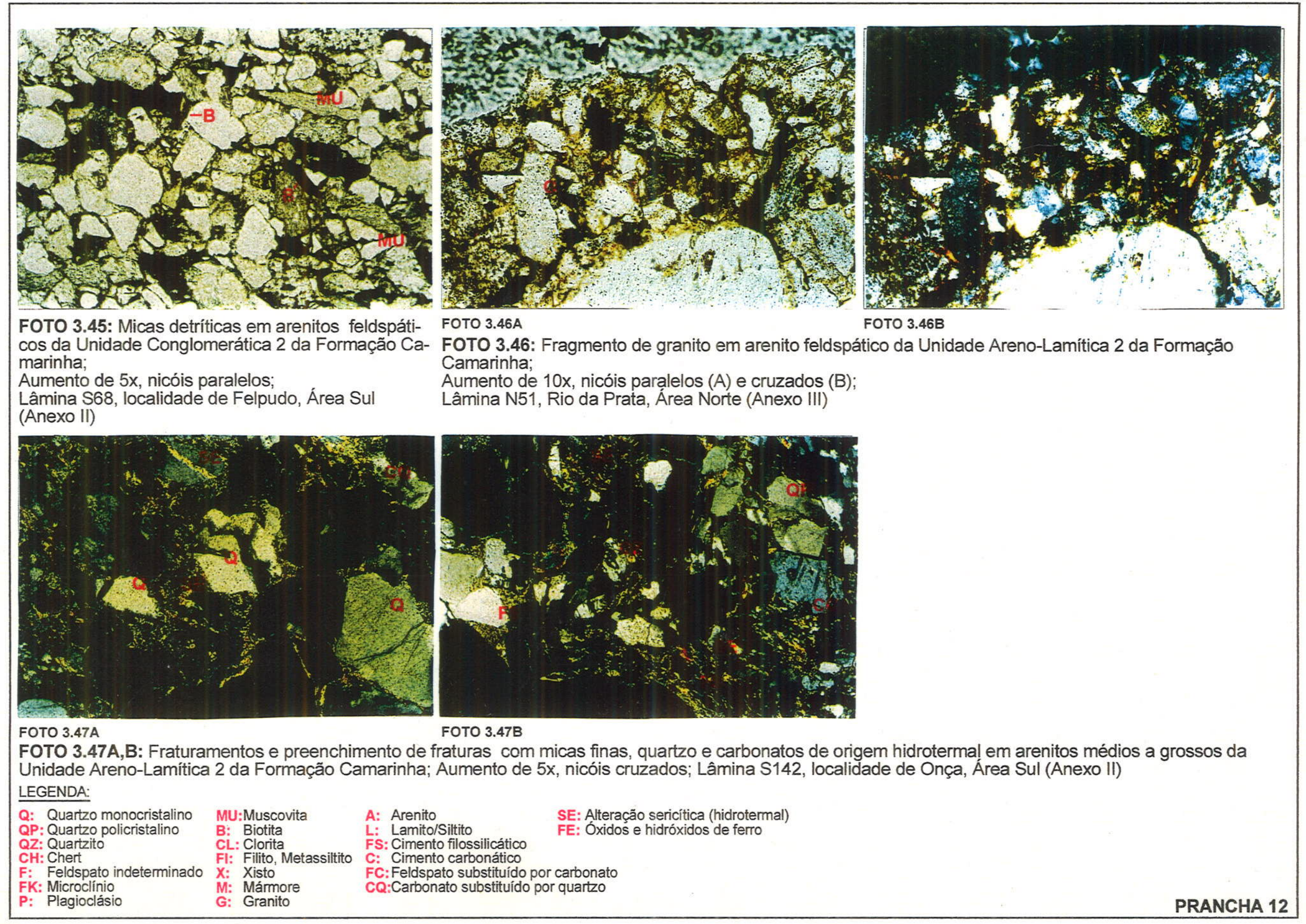


qualitativa aproximada de sua composição mineralógica, principalmente em termos de argilominerais presentes.

Foram utilizadas três amostras, obtidas nos pontos S61, S67 e S123 (próximos à localidade de Felpudo, Área Sul, Anexo II), pertencentes à Unidade Areno-Lamítica 1. Estes pontos foram escolhidos por apresentarem uma certa continuidade lateral de níveis lamíticos, permitindo a coleta de quantidades suficientes tanto para a análise difratométrica como posteriormente para análise geocronológica (Cap.6 deste trabalho). As frações finas foram submetidas à análise por Difratometria de Raios-X em amostras orientadas, sem aquecimento nem impregnação por etilenoglicol, fornecendo os difratogramas expostos na Fig.3.8.

Esses difratogramas mostram valores de reflexões basais em torno de $10 \AA, 5 \AA, 3,33 \AA$ e $2 \AA$, correspondentes às reflexões de $1^{a}$ a $4^{a}$ ordem de micas e/ou illitas; $7,4 \AA$ e $3,6 \AA$, respectivamente correspondentes às reflexões de $1^{\mathrm{a}}$ e $2^{\mathrm{a}}$ ordem de caulinitas; $2,7 \AA$ e $2,5 \AA$, respectivamente correspondentes a reflexões de $1^{\mathrm{a}}$ e $2^{\mathrm{a}}$ ordem de óxidos de ferro (hematita?); e na amostra $\mathrm{S} 61$, algumas tênues reflexões relacionadas a quartzo. Os difratogramas não oferecem dados quantitativos, devido ao difratômetro utilizado não possuir os padrões de referência necessários a essas determinações.

Como os minerais identificados não apresentam variações nas reflexões basais quando submetidos a aquecimento ou impregnações por etileno-glicol, não foram empregadas estas técnicas nas amostras estudadas. As micas/illitas presentes só podem ser distintas umas das outras por meio de análise de amostras não orientadas, tecnologia até o momento ainda não disponivel no laboratório utilizado. Estas micas/illitas podem ter origem tanto detrítica como diagenética, hidrotermal ou metamórfica. Para a distinção entre esses politipos, por meio de estudo de sua cristalinidade, também são necessárias as comparações com padrões, dos quais o difratômetro utilizado não dispõe. Entretanto, com base na análise petrográfica efetuada nos arenitos da mesma unidade e descrita no item 3.3.1 deste capítulo, optou-se pela possibilidade de origem diagnética e/ou hidrotermal para as micas/illitas, por ocorrerem na forma de cimento argiloso e sericitização disseminada freqüentemente preenchendo fraturas, sem orientação preferencial ou recristalização perceptível, e predominando grandemente (até 10\% como cimento e 13\% como sericitização) sobre a muscovita detrítica (até no máximo $4 \%$ das lâminas descritas). Ainda por comparação à análise petrográfica dos arenitos, a caulinita deve relacionar-se à alteração dos feldspatos, os óxidos de ferro à alteração de minerais opacos e ferromagnesianos e à presença de cimento ferruginoso, e o quartzo também à alteração hidrotermal e às raras ocorrências de matriz fina e intercrescimento autigênico. 

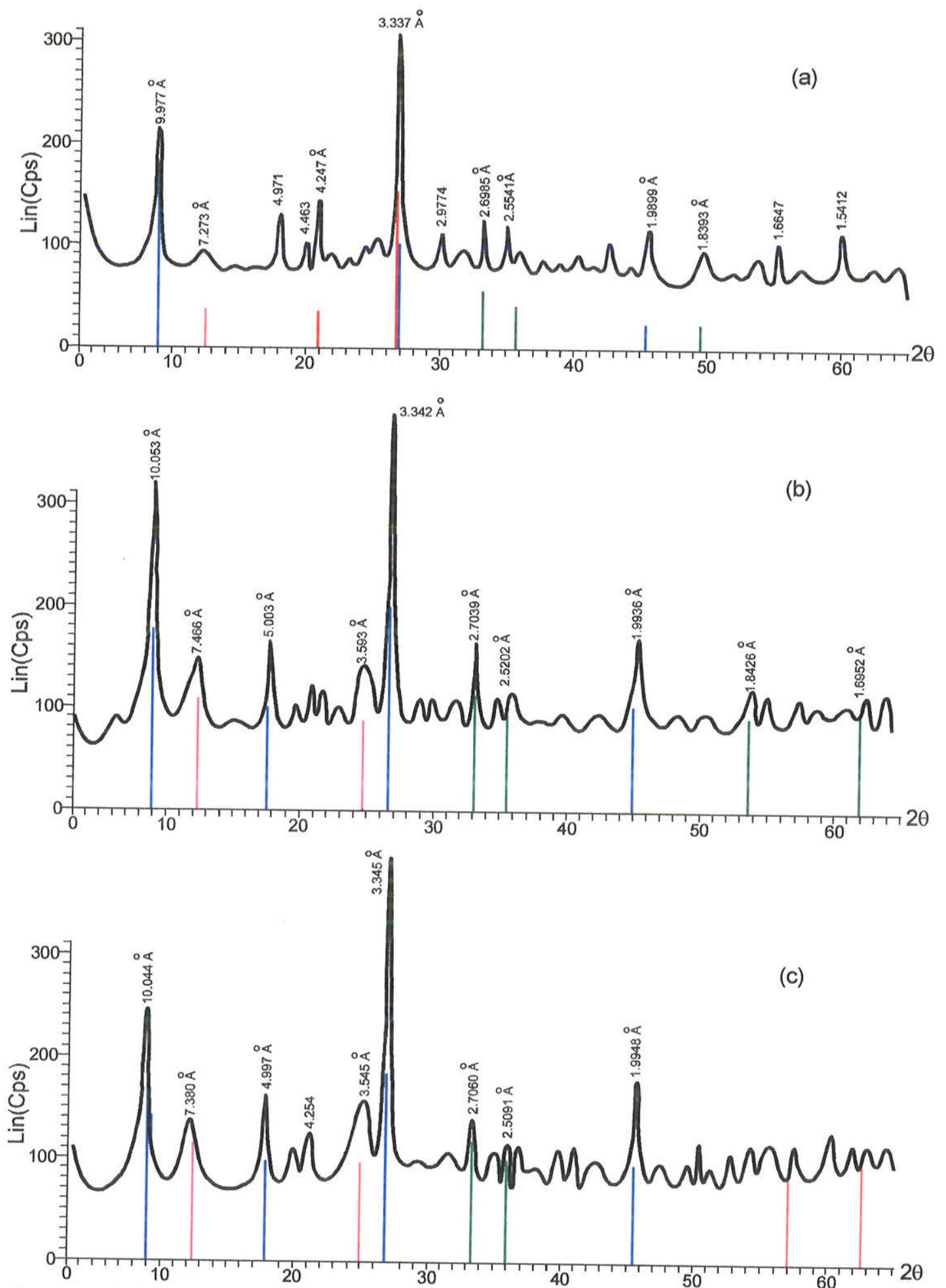

Fig.3.8: Difratogramas da fração fina de lamitos da Unidade Areno-Lamítica 1, mostrando as distâncias interplanares características de alguns minerais, sendo: Lin (Cps): Intensidade do feixe refratado em Contagens por Segundo 20: Ângulo entre o feixe incidente e o feixe difratado Valores em $\AA$ : distâncias interplanares

(a) - Ponto S61 (b) - Ponto S67 (c) - Ponto S123 (localidade de Felpudo) Illita/Mica Caulinita Quartzo Óxidos e hidróxidos de ferro 


\section{ANÁLISE ESTRATIGRÁFICA E SEDIMENTOLÓGICA}

\subsection{ANÁLISE DE PROVENIÊNCIA}

A análise de proveniência, efetuada a partir de dados de composição e paleocorrentes dos sedimentos estudados, fornece importantes informações sobre localização e tipos de áreas-fonte por ocasião da sedimentação, inclusive do ponto de vista geotectônico. Para tanto, deve-se levar em conta a composição modal dos diferentes tipos de quartzo, feldspato e fragmentos líticos, bem como os diferentes sentidos de transporte sedimentar indicados pelas medidas de paleocorrentes.

A análise petrográfica efetuada no Cap.3 (item 3.3) deste trabalho e, em menor grau, também alguns dados de medidas de paleocorrentes efetuadas em campo, fornecem alguns subsídios para um estudo de proveniência dos arenitos da Formação Camarinha. Para a análise estatística de proveniência de conglomerados e brechas por meio de histogramas de composição de clastos, são necessárias exposiçôes de afloramentos com extensão, quantidade e tamanho de clastos suficientes para que se possa efetuar uma contagem representativa, condições estas que não se verificaram em quantidade significativa na Formação Camarinha. Assim, optou-se neste trabalho por efetuar o estudo de proveniência com base principalmente na petrografia dos arenitos, análise qualitativa em campo e lâmina da composição dos conglomerados e brechas, e alguns dados de paleocorrentes obtidos.

As lâminas utilizadas para a análise estatística de proveniência dos arenitos da Formação Camarinha foram as mesmas utilizadas para a classificação modal, ou seja: 3 lâminas de amostras da Unidade Areno-Lamítica 1, coletadas nos pontos S11 (localidade de Taquaral), S60 (localidade de Felpudo) e S104 (localidade de Boqueirão), na Área Sul (Anexo I); uma lâmina de amostra de intercalação arenosa na Unidade Conglomerática 2, coletada no ponto S68 (localidade de Felpudo); e duas lâminas de amostras da Unidade Areno-Lamítica 2, coletadas nos pontos S142 (localidade de Onça, Área Sul, Anexo II) e N51 (Rio da Prata, Área Norte, Anexo III). O pequeno número de lâminas selecionadas deve-se ao elevado grau de alteração intempérica e hidrotermal das rochas, que dificulta e por vezes impede a identificação segura dos minerais necessários à análise efetuada.

Conforme exposto na análise petrográfica anteriormente apresentada neste trabalho (Cap.3, item 3.3), os arenitos da Formação Camarinha apresentam arcabouço detrítico constituído basicamente por quartzo mono e policristalino, feldspatos na grande maioria intensamente alterados (porém eventualmente identificáveis como microclínio e plagioclásio), micas como muscovita (mais raramente clorita e biotita), e fragmentos líticos como metassiltitos, quartzitos, cherts, xistos e mais raramente granitos, rochas carbonáticas e metavulcânicas. Já os conglomerados e brechas apresentam clastos de filitos, quartzitos, quartzo, rochas carbonáticas, xistos, eventualmente 
granitos, rochas cálcio-silicáticas e metavulcânicas, e ainda clastos de arenitos, siltitos e lamitos provenientes da Unidade Areno-Lamítica 1 da própria Formação Camarinha.

O quartzo monocristalino pode possuir origens as mais diversas, desde ígnea, hidrotermal (quando apresenta inclusões de vacúolos), sedimentar (grãos reciclados) ou também metamórfica (quando grãos policristalinos se desagregam ao longo do transporte). Já o quartzo policristalino pode apresentar origem tanto ígnea (quando os cristais constituintes do grão mostram contornos mais retilíneos) como metamórfica (quando os cristais mostram contornos suturados). Os feldspatos podem possuir origem tanto ígnea quanto metamórfica (rochas graníticas ou gnáissicas), e as muscovitas e cloritas são comumente derivadas de rochas metamórficas como filitos e xistos.

Os arenitos da Formação Camarinha mostram geralmente predomínio de quartzo monocristalino sobre policristalino, com freqüente ocorrência de inclusões de vacúolos, evidenciando possível origem hidrotermal. Dentre os tipos de quartzo policristalino, predomina o de contornos suturados, evidenciando fonte provavelmente metamórfica. As proporções entre os poucos grãos de feldspato identificáveis como microclínio e plagioclásio varia grandemente, não tendo sido possível estabelecer uma fonte preferencial para os mesmos (ígnea ou metamórfica) com base apenas na sua composição.

Os fragmentos líticos predominantes nos arenitos, conglomerados e brechas da Formação Camarinha são de filitos e de metassiltitos, seguidos de quartzitos, xistos e cherts. Nos arenitos, os fragmentos menos abundantes são os constituídos por rochas carbonáticas, graníticas, cálciosilicáticas e metavulcânicas. A relativa escassez desses tipos de fragmentos deve-se provavelmente à sua decomposição e desagregação ao longo do transporte, tendo sido identificados localmente alguns raros grãos extremamente alterados de biotita e hornblenda, derivados provavelmente de antigos fragmentos graníticos desagregados. Os fragmentos de rochas carbonáticas, graníticas, cálcio-silicáticas e metavulcânicas são mais comuns em arenitos, conglomerados e brechas da Área Norte (próximo à ocorrência da Formação Água Clara e do Complexo Granítico Três Córregos), ocorrendo na Área Sul principalmente na forma de clastos preservados em arenitos conglomeráticos, conglomerados e brechas que sofreram menos transporte.

Embora na Formação Camarinha sejam bastante comuns estratificações e laminações cruzadas e onduladas que poderiam fornecer medidas de sentidos de paleocorrentes, principalmente nos arenitos, lamitos e ritmitos das unidades Areno-Lamítica 1 e 2, as exposições na maioria das vezes não permitem a visualização tridimensional dessas estruturas, condição indispensável para efetuarem-se medidas confiáveis. Assim, não foi possível a obtenção de medidas em quantidades suficientes para a reunião em estações, elaboração de diagramas de rosetas e cálculo de vetores médios, tendo-se então optado pela representação do valor das mesmas na Tab.4.1 e de sua 
distribuição individual na Formação Camarinha no mapa da Fig.4.1 e no Mapa Geológico (Anexo I).

Foi coletado um total de 32 medidas de paleocorrentes, em estruturas como marcas onduladas assimétricas, estratificações cruzadas tangenciais e acanaladas, e eventualmente imbricamento de clastos. A Unidade Areno-Lamítica 1 forneceu o maior número de medidas (14, na Área Sul), sendo que na transição entre esta unidade e a Unidade Conglomerática 2 na Área Sul foram coletadas duas medidas, e na transição da Unidade Conglomerática 2 para a Unidade ArenoLamítica 2 foram coletadas 4 medidas, também na Área Sul. A Unidade Conglomerática 2 teve apenas duas medidas efetuadas (uma na Área Sul e outra na Área Norte), e a Unidade ArenoLamítica 2 forneceu 10 medidas, apenas na Área Norte. As medidas efetuadas tiveram seus valores corrigidos para planos horizontais, a partir do rebatimento dos planos de mergulho de acamamento em estereogramas. As estruturas medidas pertencem ao rank 6 de Miall (1990), ou seja, de estruturas de pequena escala.

O baixo número de medidas coletadas, impossibilitando o agrupamento em estações, distribuição em diagramas de rosetas e cálculo do vetor médio, conforme recomendado por Selley (1982), Miall (1990) e Assine (1994, 1996), não permite uma análise confiável de tendência de direção de preenchimento da bacia da Formação Camarinha, devido à falta de representatividade estatística das medidas efetuadas. Pode-se então, no máximo, analisá-las apenas individualmente, nấo como padrões de preenchimento da bacia, mas como caminhos a serem explorados com mais aprofundamento e detalhe em estudos futuros.

Com base na Fig.4.1, verifica-se que na Área Norte é possível observar dois tipos de sentidos individuais de paleocorrentes: um unidirecional aproximadamente de norte para sul, e outro bidirecional, com sentidos praticamente opostos para leste e oeste. Como estas medidas bidirecionais foram coletadas a partir de marcas onduladas assimétricas superpostas, é possível que estes sentidos tratem-se de uma direção de retrabalhamento por ondas de sedimentos provenientes de norte para sul, com fontes representadas pela Formação Água Clara e pelo Complexo Granítico Três Córregos (condizentes com a composição verificada para os sedimentos dessa área).

$\mathrm{Na}$ Área Sul, predominam direções de paleocorrentes para noroeste, embora também ocorram direções para sudeste e nordeste, eventualmente sudoeste, principalmente próximo ao limite sudeste dessa área. Se estes sentidos puderem ser futuramente confirmados como padrão em uma análise mais representativa, poderão indicar um preenchimento a partir de sudeste (com fontes representadas pelo Complexo Atuba e Formação Capiru, condizentes com a composição verificada para os sedimentos), com pequenos desvios para oeste e sudoeste nas regiões de Purunã e Camarinha (com fontes representadas pelas formações Capiru, Votuverava e Água Clara, também condizentes com a composição observada dos sedimentos). 


\begin{tabular}{|c|c|c|c|c|}
\hline PTO ( ÁREA) & UNIDADE & LOCALIDADE & SENTIDO CORRIGIDO & ESTRUTURA \\
\hline $\mathrm{SI36( \textrm {Sul } )}$ & Areno-Lam. 1 & Onça-Varzedo & $\mathrm{S} 06^{\circ} \mathrm{E}$ & Cruzada tangencial \\
\hline $\mathrm{SI} 36(\mathrm{Sul})$ & Areno-Lam. I & Onça-Varzedo & $\mathrm{S} 50^{\circ} \mathrm{W}$ & Cruzada tangencial \\
\hline S43 (Sul) & Areno-Lam.1 & Onça-Varzedo & $\mathrm{N} 70^{\circ} \mathrm{W}$ & Cruzada tangencial \\
\hline S61 (Sul) & Areno-Lam. 1 & Felpudo & $\mathrm{N} 76^{\circ} \mathrm{W}$ & Cruzada tangencial \\
\hline $\mathrm{S} 122(\mathrm{Sul})$ & Areno-Lam. 1 & Felpudo & $\mathrm{N} 76^{\circ} \mathrm{W}$ & Cruzada tangencial \\
\hline S122 (Sul) & Areno-Lam. I & Felpudo & $\mathrm{N} 81^{\circ} \mathrm{W}$ & Cruzada tangencial \\
\hline S103 (Sul) & Areno-Lam.1 & Boqueirão & $\mathrm{N} 43^{\circ} \mathrm{W}$ & Ondul. Assimétrica \\
\hline S103(Sul) & Areno-Lam.1 & Boqueirão & $\mathrm{N} 56^{\circ} \mathrm{W}$ & Ondul. Assimétrica \\
\hline S103 (Sul) & Areno-Lam. 1 & Boqueirão & $\mathrm{N} 72^{\circ} \mathrm{W}$ & Ondul. Assimétrica \\
\hline S103 (Sul) & Areno-Lam. 1 & Boqueirão & $\mathrm{N} 66^{\circ} \mathrm{W}$ & Ondul. Assimétrica \\
\hline Slo3 (Sul) & Areno-Lam. 1 & Boqueirão & $\mathrm{N} 65^{\circ} \mathrm{W}$ & Ondul. Assimétrica \\
\hline S103 (Sul) & Areno-Lam.1 & Boqueirão & $\mathrm{N} 78^{\circ} \mathrm{W}$ & Ondul. Assimétrica \\
\hline S105 (Sul) & Areno-Lam. 1 & Boqueirão & $\mathrm{S} 27^{\circ} \mathrm{W}$ & Cruzada tangencial \\
\hline Sll (Sul) & Areno-Lam.l & Taquaral & $\mathrm{S} 52^{\circ} \mathrm{W}$ & Ondul. Assimétrica \\
\hline S42 (Sul) & A.Lam.1/Cg.2 & Onça & $\mathrm{N} 37^{\circ} \mathrm{E}$ & Cruzada tangencial \\
\hline S54 (Sul) & A.Lam. $1 / \mathrm{Cg} .2$ & Onça & $\mathrm{S} 42^{\circ} \mathrm{E}$ & Cruzada tangencial \\
\hline S159(Sul) & Conglom. 2 & Purunã & $\mathrm{N} 80^{\circ} \mathrm{W}$ & Imbricam. de clastos \\
\hline S45 (Sul) & Cg.2/A.Lam.2 & Varzedo & $\mathrm{N} 32^{\circ} \mathrm{W}$ & Cruzada acanalada \\
\hline $\mathrm{S} 45(\mathrm{Sul})$ & Cg.2/A.Lam.2 & Varzedo & $\mathrm{N} 56^{\circ} \mathrm{W}$ & Cruzada acanalada \\
\hline $\mathrm{S} 45(\mathrm{Sul})$ & Cg.2/A.Lam.2 & Varzedo & $\mathrm{N} 28^{\circ} \mathrm{E}$ & Cruzada acanalada \\
\hline $\mathrm{S} 45(\mathrm{Sul})$ & Cg.2/A.Lam.2 & Varzedo & $\mathrm{N} 78^{\circ} \mathrm{E}$ & Cruzada tangencial \\
\hline N42 (Norte) & Conglom. 2 & Santa Cruz & $\mathrm{N} 82^{\circ} \mathrm{W}$ & Imbricam. de clastos \\
\hline N51 (Norte) & Areno-Lam.2 & Rio da Prata & $\mathrm{N} 86^{\circ} \mathrm{W}$ & Ondul. Assimétrica \\
\hline N51 (Norte) & Areno-Lam.2 & Rio da Prata & $\mathrm{N} 86^{\circ} \mathrm{W}$ & Ondul. Assimétrica \\
\hline N51 (Norte) & Areno-Lam.2 & Rio da Prata & $\mathrm{N} 86^{\circ} \mathrm{W}$ & Ondul. Assimétrica \\
\hline N51 (Norte) & Areno-Lam. 2 & Rio da Prata & $\mathrm{N} 86^{\circ} \mathrm{W}$ & Ondul. Assimétrica \\
\hline N51 (Norte) & Areno-Lam.2 & Rio da Prata & $\mathrm{S} 69^{\circ} \mathrm{E}$ & Ondul. Assimétrica \\
\hline N51 (Norte) & Areno-Lam.2 & Rio da Prata & $S 82^{\circ} \mathrm{E}$ & Ondul. Assimétrica \\
\hline N51 (Norte) & Areno-Lam.2 & Rio da Prata & $\mathrm{S} 73^{\circ} \mathrm{W}$ & Ondul. Assimétrica \\
\hline N51 (Norte) & Areno-Lam.2 & Rio da Prata & $S 77^{\circ} \mathrm{W}$ & Ondul. Assimétrica \\
\hline N51 (Norte) & Areno-Lam.2 & Rio da Prata & $\mathrm{S} 79^{\circ} \mathrm{W}$ & Ondul. Assimétrica \\
\hline N5! (Norte) & Areno-Lam.2 & Rio da Prata & $\mathrm{S} 03^{\circ} \mathrm{W}$ & Ondul. Assimétrica \\
\hline
\end{tabular}

Tab.4.1: Sentidos de paleocorrentes corrigidos nas diferentes unidades da Formação Camarinha 


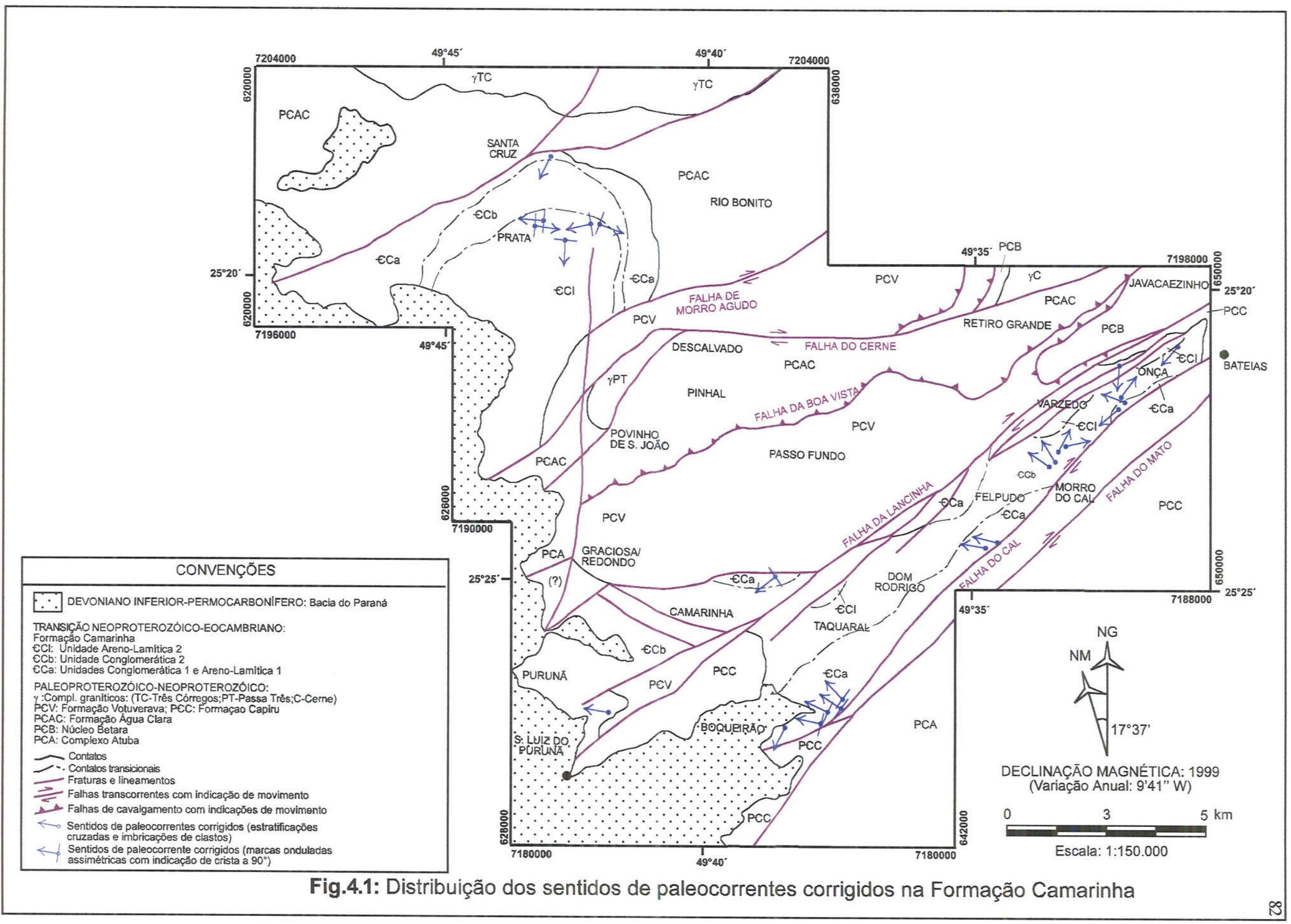


O baixo grau de arredondamento dos fragmentos constituintes dos sedimentos arenosos e conglomeráticos da Formação Camarinha, aliado à imaturidade composicional dos mesmos, evidencia pouco transporte, indicando fontes próximas. De acordo com a composição dos sedimentos e com os sentidos de paleocorrentes obtidos, verificamse que essas fontes seriam representadas pelo Complexo Atuba, que contribui com fragmentos de quartzo mono $\mathrm{e}$ policristalino, feldspato, e eventualmente micas e rochas graníticas; Formações Capiru e Votuverava, contribuindo com micas e fragmentos de filitos, metassiltitos, quartzo policristalino, quartzito e rochas carbonáticas; Formação Água Clara, que contribui com micas e fragmentos de xistos, quartzo policristalino, quartzitos, cherts, rochas carbonáticas, cálcio-silicáticas e metavulcânicas; e Complexo Granítico Três Córregos, contribuindo com quartzo monocristalino, feldspatos e rochas graníticas. O Núcleo Betara pode eventualmente representar uma potencial fonte de fragmentos de quartzo policristalino, xistos, quartzitos e rochas carbonáticas, metavulcânicas e granitóides, embora apenas dois sentidos de paleocorrentes que possam corroborar este fato tenham sido detectados.

Do ponto de vista geotectônico, a composição dos arenitos da Formação Camarinha analisada neste capítulo apresenta padrões de petrofácies segundo Dickinson (1988) dos tipos arcosiana (com predomínio de quartzo monocristalino e feldspato, o qual mostra proporções variáveis entre feldspato potássico e plagioclásio) e quartzolítica (com proporções variadas entre quartzo monocristalino, quartzo policristalino e fragmentos líticos, perfazendo um total que predomina sobre os feldspatos). A petrofácies arcosiana seria característica de fontes constituídas por blocos continentais estáveis soerguidos por falhas ou raízes de arcos magmáticos, depositada geralmente em rifts, aulacógenos e bacias de pull-apart, enquanto que a petrofácies quartzolítica seria característica de fontes constituídas por cinturões de dobramentos e cavalgamentos, depositada em bacias de foreland. Entretanto, é possível a ocorrência de petrofácies mistas derivadas de fontes diversas, como blocos continentais estáveis soerguidos por falhas (interiores cratônicos, embasamentos de cinturões orogênicos ou de bacias do tipo rift, aulacógeno ou pull-apart), arcos magmáticos (desde menos dissecados, com predomínio de clastos e grãos de origem vulcânica, até mais dissecados, com raízes plutônicas expostas) e metassedimentos deformados (complexos de subducção, cinturões orogênicos) presentes em uma mesma região, como parece ser o caso dos sedimentos da Formação Camarinha analisados neste capítulo.

Tal superposição de fontes pode ser bem evidenciada no diagrama QmFLt de Dickinson et al. (1983) (Fig.4.2), onde as amostras de arenitos plotadas mostram origem variando de arco magmático dissecado a cinturão orogênico, até o limite com bloco continental estável soerguido. Esta interpretação é condizente com a realidade geológica conhecida da região, onde ocorrem esses diversos tipos de fontes, representados pelas unidades do embasamento da bacia da Formação 


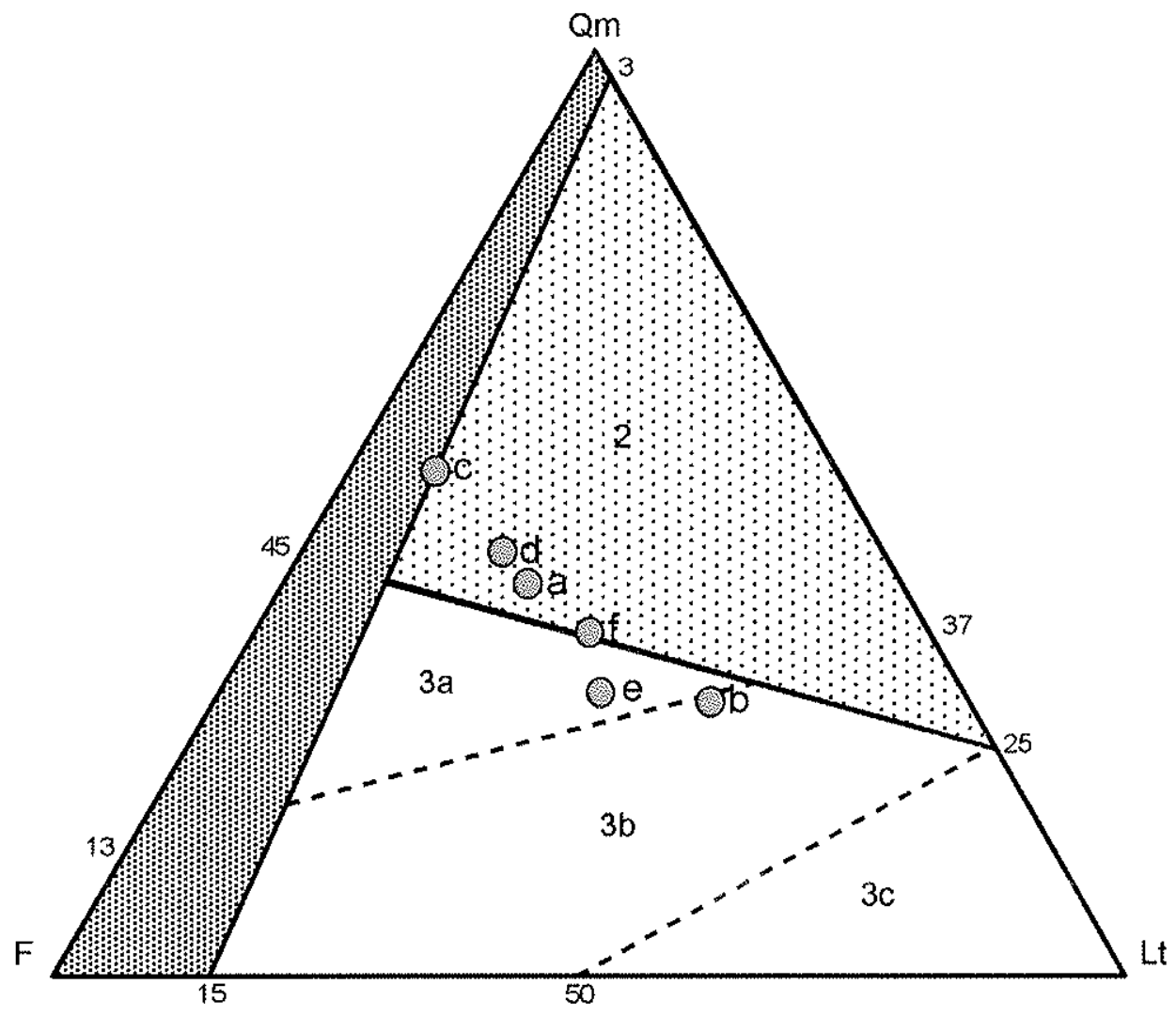

Fig.4.2: Diagrama QmFLt modificado de Dickinson et al. (1983) para ambientes geotectônicos de proveniência de arenitos, sendo:

Qm - Quartzo monocristalino

F - Feldspatos

Lt - Fragmentos líticos totais (instáveis, quartzosos e quartzo policristalino)

1 - Ambiente de bloco continental estável soerguido por falhas

(Interior cratônico, embasamento de cinturão orogênico, embasamento de bacias limitadas por falhas)

: 2 - Ambiente de cinturão orogênico

3 - Ambiente de arco magmático

$3 a$ - Arco dissecado (exposição de raiz plutônica); 3b - Transição entre arco dissecado e não dissecado; 3c - Arco não dissecado (vulcânico)

a - Ponto S11 (Unidade Areno-Lamítica 1, Área Sul, localidade de Taquaral)

b - Ponto S60 (Unidade Areno-Lamítica 1, Área Sul, localidade de Felpudo)

c - Ponto 104a (Unidade Areno-Lamímita 1, Área Sul, localidade de Boqueirão)

d - Ponto S68 (Unidade Conglomerática 2, Área Sul, localidade de Felpudo)

e - Ponto S142 (Unidade Areno-Lamítica 2, Área Sul, localidade de Onça)

f - Ponto N51 (Unidade Areno-Lamítica 2, Área Norte, localidade de Prata) 
Camarinha (Complexo Atuba, formações Capiru, Votuverava e Água Clara, e complexos graníticos, descritos no Cap.2, item 2.2 do presente trabalho). Como esse diagrama e a classificação de petrofácies são baseados em modelos mais recentes e reconhecidos, sua aplicação a ambientes mais antigos como a Formação Camarinha, embora mostre-se coerente no presente trabalho, deve ser empregada com a devida cautela.

\subsection{ANÁLISE DE FÁCIES E AMBIENTES}

A análise de fácies efetuada neste trabalho visou proporcionar uma interpretação paleoambiental dos sedimentos da Formação Camarinha, com base no estudo e interpretação das litofácies identificadas. Essas litofácies foram analisadas segundo suas características composicionais, texturais e estruturais, que as tornam características de processos deposicionais especificos. Como uma litofácies individualmente não define por si só um ambiente de sedimentação, procurou-se analisar o conjunto das mesmas, na forma de associações ou assembléias inter-relacionadas e cíclicas. Essas assembléias representam, portanto, conjuntos de processos atuantes num mesmo ambiente ao longo do tempo de forma cíclica, levando a empilhamentos faciológicos verticais característicos das migrações laterais dos ambientes. Assim, a análise das assembléias de fácies e suas inter-relações e empilhamentos permite a inferência não só do(s) tipo(s) de ambiente(s) sedimentar(es) vigente(s) à época da sedimentação, como ainda a evolução dos mesmos ao longo do tempo, fornecendo assim a história do preenchimento da bacia.

Como não ocorrem camadas-guia necessárias a uma correlação mais precisa entre as litofácies constituintes da Formação Camarinha, e a pouca continuidade lateral de seus afloramentos também dificulta essa correlação, as mesmas foram analisadas segundo sua composição, texturas e estruturas, levando-se em conta o empilhamento vertical observado nas seções levantadas em campo e expostas no Cap.3 (item 3.2, Figs. 3.3. a 3.6) deste trabalho. As fácies identificadas, de natureza tanto subaquosa como subaérea, foram analisadas e classificadas segundo os esquemas apresentados no Cap.1 (item 1.3) deste trabalho, propostos por Miall (1977, 1978a,b, 1990), com modificações introduzidas por McPherson et al. (1987, 1988), Fritz e Moore (1988), e Blair e McPherson (1992). Estes esquemas foram inicialmente estabelecidos por Miall (1977, 1978a,b, 1990) como aplicados a fácies somente de natureza subaérea, mais especificamente de sistemas fluviais. Entretanto, pelo fato de os códigos de fácies empregados referirem-se a processos e não ambientes deposicionais (sendo o ambiente apenas uma interpretação resultante da análise dos conjuntos de processos que resultam nas fácies descritas), para alguns processos que ocorrem também em ambiente subaquoso (como, por exemplo, fluxos de detritos) o resultado faciológico pode assemelhar-se ao resultante dos mesmos processos quando ocorrem em ambiente subaéreo. 
Assim, parte dos processos descritos nos esquemas de fácies utilizados pode ser aplicada também a certos ambientes subaquosos, como fizeram McPherson et al. (1987, 1988), Fritz e Moore (1988), e Blair e McPherson (1992). As fácies subaquosas identificadas neste trabalho que não encontram equivalentes subaéreos descritos nos esquemas citados serão referidas sem o respectivo código de identificação.

O Quadro 4.1 mostra as fácies identificadas na Formação Camarinha segundo as unidades onde ocorrem, com seus respectivos códigos e interpretações de ambientes e processos atuantes. Com base nas fácies identificadas e na forma como as mesmas se sucedem ao longo das unidades da Formação Camarinha, observa-se que ocorrem uma granodecrescência representativa de uma retrogradação do preenchimento sedimentar da Unidade Conglomerática 1 para a Unidade ArenoLamítica 1, uma granocrescência representando uma progradação do preenchimento sedimentar da Unidade Areno-Lamítica 1 para a Unidade Conglomerática 2, e novamente uma granodecrescência representativa de retrogradação do preenchimento sedimentar da Unidade Conglomerática 2 para a Unidade Areno-Lamítica 2. Essas retrogradações e progradações ocorrem de sudeste para noroeste na Área Sul, e de norte para sul na Área Norte, segundo o empilhamento observado, as relações de topo e base apresentadas no Cap.3 (item 3.2) deste trabalho, e os sentidos de paleocorrente obtidos. Da base para o topo das unidades da Formação Camarinha, verificou-se a seguinte sucessão de fácies e ambientes, tanto na Área Sul como na Área Norte:

- Na Unidade Conglomerática 1, verifica-se que não ocorrem fácies de natureza subaérea e caráter proximal (tais como depósitos de fluxos de detritos subaéreos na região proximal de leques), mesmo onde o contato com o embasamento da bacia mostra-se exposto, (ponto S102, localidade de Boqueirão, Área Sul, Anexo II), levando a crer que as mesmas não se encontram preservadas. As fácies que ocorrem nessa unidade e na transição da mesma para a Unidade Areno-Lamítica 2 (Gmu - Foto 4.1, e arenitos, siltitos e lamitos maciços a incipientemente estratificados), pela sua pobreza em estratificações ou laminações bem definidas, são características de fluxos gravitacionais e de ressedimentação diversos (detritos, lama e fluxos liquefeitos), cuja natureza subaquosa é evidenciada por incipientes estratificações paralelas, gradacionais e cruzadas muito incipientes, indicativas de um mínimo de retrabalhamento, além da estreita associação com outras fácies subaquosas na transição para a região proximal da Unidade Areno-Lamítica 1, como pode ser observado nas localidades de Boqueirão e Taquaral, Área Sul;

- Na porção basal a intermediária, ou seja, na região proximal na Unidade Areno-Lamítica 1, os depósitos da Unidade Conglomerática 1 associam-se a outros depósitos, formados por fácies St e Sp de dunas subaquosas características de depósitos arenosos de barras de desembocadura em 


\begin{tabular}{|c|c|c|c|}
\hline UNID. & CÓD. & DESCRIÇĀO & PROCESSOS E AMBIENTES \\
\hline \multirow{4}{*}{ 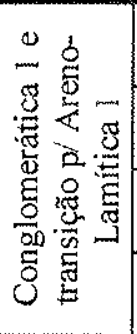 } & Gmu & $\begin{array}{l}\text { Conglomerados maciços a incipientemente } \\
\text { estratificados, gradacionais, sustentados por clastos }\end{array}$ & $\begin{array}{l}\text { Fluxos gravitacionais subaquosos de detritos } \\
\text { em frente deltaica proximal a mediana }\end{array}$ \\
\hline & - & $\begin{array}{l}\text { Arenitos grossos a conglomeráticos, médios a finos, } \\
\text { maciços a incipientemente estratificados }\end{array}$ & $\begin{array}{l}\text { Fluxos gravitacionais subaquosos liquefeitos } \\
\text { em frente deltaica proximal a mediana }\end{array}$ \\
\hline & - & $\begin{array}{c}\text { Arenitos médios a finos, maciços a incipientemente } \\
\text { estratificados }\end{array}$ & $\begin{array}{c}\text { Fluxos gravitacionais subaquosos liquefeitos } \\
\text { em frente deltaica proximal a mediana }\end{array}$ \\
\hline & - & Siltitos e lamitos maciços & $\begin{array}{c}\text { Fluxos gravitacionais subaquosos de lama em } \\
\text { frente deltaica mediana }\end{array}$ \\
\hline \multirow{3}{*}{ 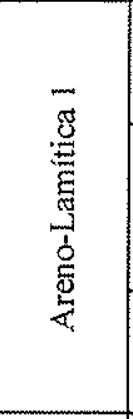 } & St, Sp & $\begin{array}{c}\text { Arenitos médios a finos com estratificações cruzadas } \\
\text { acanalada e tabular }\end{array}$ & $\begin{array}{l}\text { Migração de dunas subaquosas em barras de } \\
\text { desembocadura em regiẫo de frente deltaica } \\
\text { mediana a distal }\end{array}$ \\
\hline & $\begin{array}{l}\mathrm{Sh} \\
\mathrm{Sp}, \mathrm{Sr}\end{array}$ & $\begin{array}{c}\text { Arenitos conglomeráticos com intraclastos na base, } \\
\text { passando a arenitos médios com estratificações } \\
\text { paralelas, cruzadas tangenciais e climbings, com } \\
\text { ondulações no topo } \\
\end{array}$ & $\begin{array}{l}\text { Correntes de turbidez de alta densidade } \\
\text { passando a baixa densidade, com } \\
\text { retrabalhamento por ondas em região de } \\
\text { frente deltaica mediana a distal } \\
\end{array}$ \\
\hline & - & $\begin{array}{l}\text { Siltitos, lamitos e ritmitos com laminações paralelas, } \\
\text { onduladas, cruzadas e estruturas de sobrecarga }\end{array}$ & $\begin{array}{l}\text { Espraiamento e dissipação de fluxo } \\
\text { subaquoso com retrabalhamento por ondas } \\
\text { em região de frente deltaica distal }\end{array}$ \\
\hline \multirow{7}{*}{ 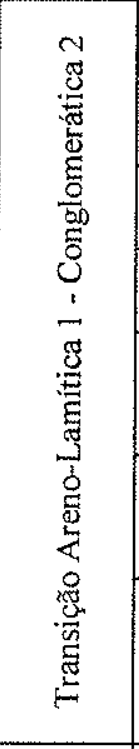 } & 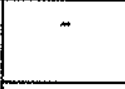 & Siltitos e lamitos maciços & $\begin{array}{c}\text { Fluxos gravitacionais subaquosos de lama em } \\
\text { frente deltaica mediana }\end{array}$ \\
\hline & - & $\begin{array}{c}\text { Arenitos médios a finos, maciços a incipientemente } \\
\text { estratificados }\end{array}$ & $\begin{array}{c}\text { Fluxos gravitacionais subaquosos liquefeitos } \\
\text { em frente deltaica proximal a mediana }\end{array}$ \\
\hline & - & $\begin{array}{l}\text { Arenitos grossos a conglomeráticos, maciços a } \\
\text { incipientemente estratificados }\end{array}$ & $\begin{array}{l}\text { Fluxos gravitacionais subaquosos liquefeitos } \\
\text { em frente deltaica proximal a mediana }\end{array}$ \\
\hline & Gmu & $\begin{array}{l}\text { Conglomerados maciços a incipientemente } \\
\text { estratificados, gradacionais, sustentados por clastos }\end{array}$ & $\begin{array}{l}\text { Fluxos gravitacionais subaquosos de detritos } \\
\text { em frente deltaica proximal a mediana }\end{array}$ \\
\hline & Gh & $\begin{array}{l}\text { Conglomerados com estratificação paralela e } \\
\text { imbricação incipientes }\end{array}$ & $\begin{array}{c}\text { Preenchimento de canais na superficie de } \\
\text { depósitos de sheet-floods em região mediana } \\
\text { de leques subaéreos }\end{array}$ \\
\hline & $\mathrm{St}, \mathrm{Sp}$ & $\begin{array}{c}\text { Arenitos médios a grossos com base conglomerática, } \\
\text { gradacionais e com estratificaçōes cruzadas acanalada } \\
\text { e tabular }\end{array}$ & $\begin{array}{l}\text { Fluxos desconfinados (sheet-floods) com } \\
\text { migração de dunas subaquosas em região } \\
\text { mediana de leques subaéreos }\end{array}$ \\
\hline & $\mathrm{Fl}$ & $\begin{array}{l}\text { Arenitos finos, siltitos e lamitos finamente laminados } \\
\text { com laminação paralela e ondulaçóes }\end{array}$ & $\begin{array}{c}\text { Depósitos de decantação e transbordamento } \\
\text { ou dissipação de enchentes na superfície de } \\
\text { depósitos de sheet-floods em região mediana } \\
\text { de leques subaéreos }\end{array}$ \\
\hline \multirow{3}{*}{ 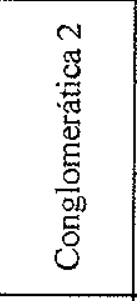 } & $\mathrm{Gm}$ & Conglomerados maciços sustentados por clastos & $\begin{array}{l}\text { Fluxos gravitacionais subaéreos de detritos } \\
\text { em região de leques proximais }\end{array}$ \\
\hline & Gms & Conglomerados maciços sustentados por matriz & $\begin{array}{l}\text { Fluxos gravitacionais subaéreos de detritos } \\
\text { em região de leques proximais }\end{array}$ \\
\hline & $\mathrm{Sh}, \mathrm{Sp}$ & $\begin{array}{c}\text { Arenitos grossos com estratificação paralela e cruzada } \\
\text { incipientes }\end{array}$ & $\begin{array}{l}\text { Preenchimento de canais na superficie de } \\
\text { depósitos gravitacionais de fluxos de detritos } \\
\text { em região proximal de leques subaéreos }\end{array}$ \\
\hline \multirow{2}{*}{ 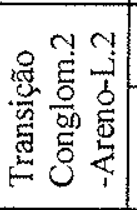 } & Gmu & $\begin{array}{l}\text { Conglomerados maciços a incipientemente } \\
\text { estratificados. gradacionais, sustentados por clastos }\end{array}$ & $\begin{array}{l}\text { Fluxos gravitacionais subaquosos de detritos } \\
\text { em frente deltaica proximal a mediana }\end{array}$ \\
\hline & St, Sp & $\begin{array}{l}\text { Arenitos médios a finos com estratificações cruzadas } \\
\text { acanalada e tabular }\end{array}$ & $\begin{array}{c}\text { Migração de dunas subaquosas em barras de } \\
\text { desembocadura em regiẫo de frente deltaica } \\
\text { mediana a distal }\end{array}$ \\
\hline \multirow{2}{*}{ 莺莺 } & - & Arenitos médios com marcas onduladas bidirecionais & $\begin{array}{c}\text { Retrabalhamento por ondas de depósitos em } \\
\text { barras de desembocadura na região de frente } \\
\text { deltaica mediana a distal }\end{array}$ \\
\hline & - & $\begin{array}{l}\text { Siltitos, lamitos e ritmitos com laminações paralelas, } \\
\text { onduladas, cruzadas e estruturas de sobrecarga }\end{array}$ & $\begin{array}{l}\text { Espraiamento e dissipação de fluxo } \\
\text { subaquoso com retrabalhamento por ondas } \\
\text { em região de frente deltaica distal }\end{array}$ \\
\hline
\end{tabular}

Quadro 4.1: Fácies identificadas nas unidades da Formação Camarinha e suas interpretações 
frentes deltaicas, além de fácies $\mathrm{Sh}, \mathrm{Sp}$ e $\mathrm{Sr}$ em pacotes gradacionais caracterizando correntes de turbidez de alta a baixa densidade, com retrabalhamentos por ondas no topo (Fotos 4.2 e 4.3, localidade de Boqueirão, Área Sul). Os depósitos resultantes dessas correntes são representados por sequiências turbidíticas com uma base de granulometria grossa a conglomerática de alta densidade (níveis R3 e S3/Ta de Lowe, 1982), que grada para níveis médios com estratificações paralelas, cruzadas e climbings de baixa densidade no topo (níveis Tb, Tc e Td de Lowe, 1982). O nível Te não se encontra preservado, ocorrendo intraclastos provavelmente provenientes de erosão do mesmo na base conglomerática do fluxo seguinte;

- Na porção intermediária a distal da Unidade Areno-Lamítica 1, os ritmitos síltico-argilosos com laminações paralelas, onduladas e cruzadas são característicos das porções mais distais das barras de desembocadura, onde os sedimentos mais finos espraiam-se e depositam-se sob condições de águas mais calmas devido à perda de velocidade da corrente transportadora, estando porém ainda sujeitos a ações de ondas e correntes, como nas localidades de Boqueirão, Dom Rodrigo e Felpudo, Área Sul (Fotos 4.4 a 4.6);

- Na transição da Unidade Areno-Lamítica 1 para a Unidade Conglomerática 2, verifica-se o início da progradação desta última sobre a primeira, na forma de novos depósitos gravitacionais subaquosos como siltitos, arenitos e conglomerados maciços visíveis nas localidades de Dom Rodrigo (Área Sul) e Santa Cruz (Área Norte) (Foto 4.7), passando próximo ao topo para depósitos subaquosos a subaéreos de fluxos desconfinados na forma de sheet-floods (fácies St e $\mathrm{Sp}$, Foto 4.8), representativos de fácies medianas a distais de leques aluviais e fandeltas. Eventualmente ocorrem, no topo dos depósitos de sheet-flood, fácies mais finas de decantação final dos fluxos desconfinados em depressões restritas (fácies $\mathrm{Fl}$, foto 4.9), que podem ser retrabalhados pelos fluxos seguintes. Conglomerados incipientemente estratificados (fácies Gh) podem representar preenchimentos de canais cortando a superficie dos depósitos de sheet-flood e gerando estruturas erosivas (Foto 4.10). Esses depósitos de sheet-flood podem ser observados nas localidades de Onça, Varzedo, Felpudo e Dom Rodrigo (Área Sul);

- Na Unidade Conglomerática 2, novos depósitos gravitacionais de fluxo de detritos, porém subaéreos, passam a ocorrer associados aos depósitos de sheet-flood e posteriormente predominando sobre os mesmos, sendo representados pelas fácies Gm e Gms (Fotos $4.11 \mathrm{e}$ 4.12), freqüentes nas localidades de Onça, Varzedo, Felpudo, Dom Rodrigo, Camarinha e Purunã, na Área Sul, e Rio dos Matos e Itambezinho-Prata, na Área Norte. Esses depósitos são característicos das porções proximais a medianas de leques aluviais e fandeltas, podendo apresentar raros preenchimentos de canais superficiais representados pelas fácies $\mathrm{Sh}$ e $\mathrm{Sp}$ (Foto 4.13); 


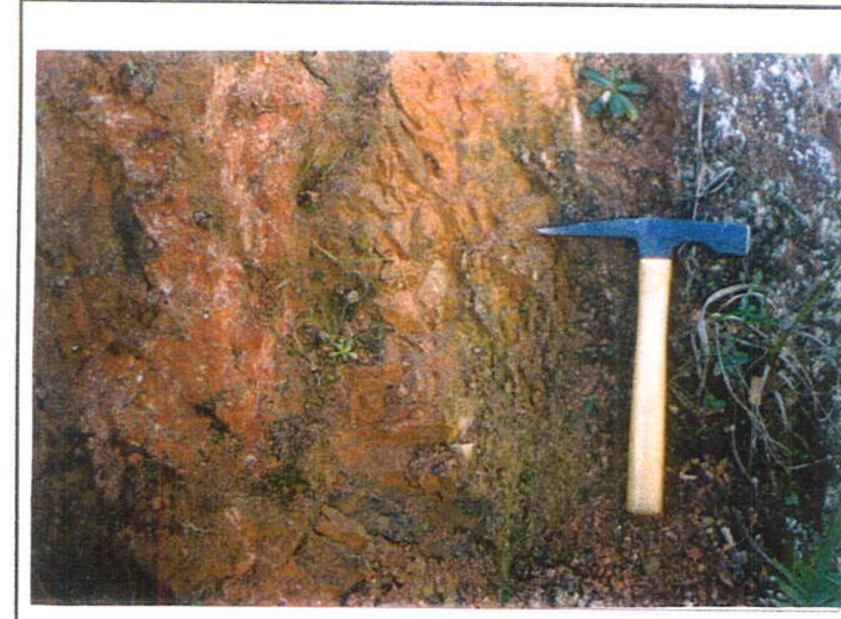

FOTO 4.1: Fácies Gmu representativa de fluxos de detritos na Unidade Conglomerática 1 da Formação Camarinha (ponto S102, localidade de Boqueirão, Area Sul - Anexo II)

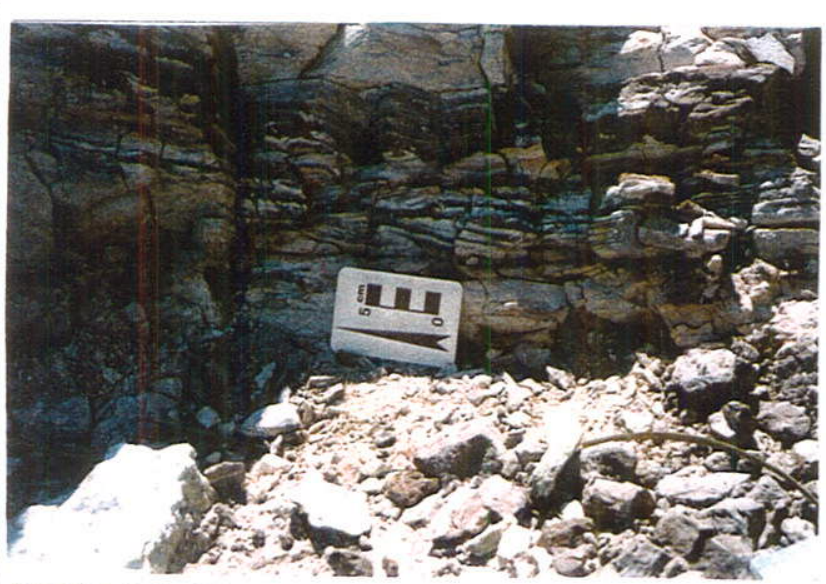

FOTO 4.4: Fácies de ritmitos síltico-argilosos com laminações paralelas, onduladas e cruzadas diver sas, representando depósitos de barra de desem bocadura distais em zonas de frente deltaica na Unidade Areno-Lamítica 1 da Formação Camarinha (ponto S103, localidade de Boqueirão, Área Sul Anexo II)
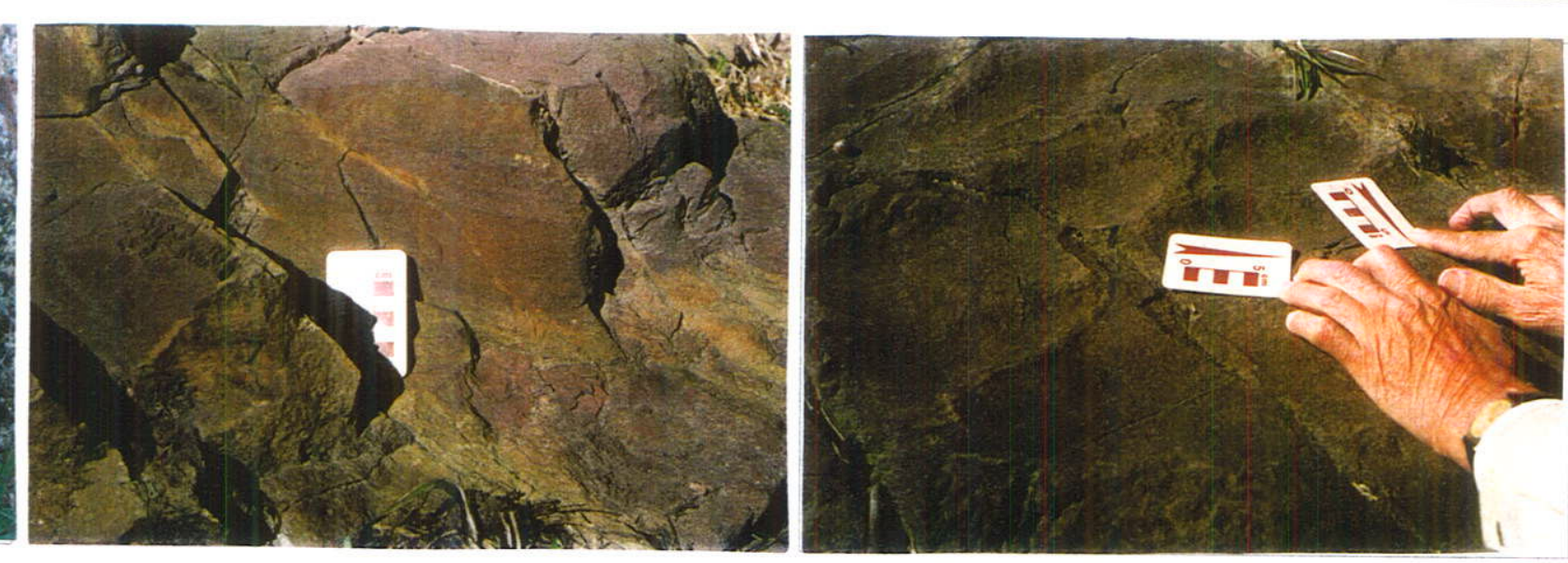

FOTO 4.2: Fácies Sh e Sp representativas de correntes de turbi- FOTO 4.3: Fácies Sr representativa de retrabalhamendez de alta a baixa densidade em arenitos gradacionais da Uni- to por ondas no topo de depósitos de correntes de dade Areno-Lamitica 1 da Formaçấo Camarinha, mostrando base conglomerática com intraclastos siltico-argilosos passando a are- turbidez de alta a baixa densidade na Unidade Arenonitos com estratificação paralela e cruzada climbing) Lamítica 1 da Formação Camarinha (ponto S103, lo(ponto S103, localidade de Boqueirão, Área Sul - Anexo II) calidade de Boqueirão, Área Sul - Anexo II)
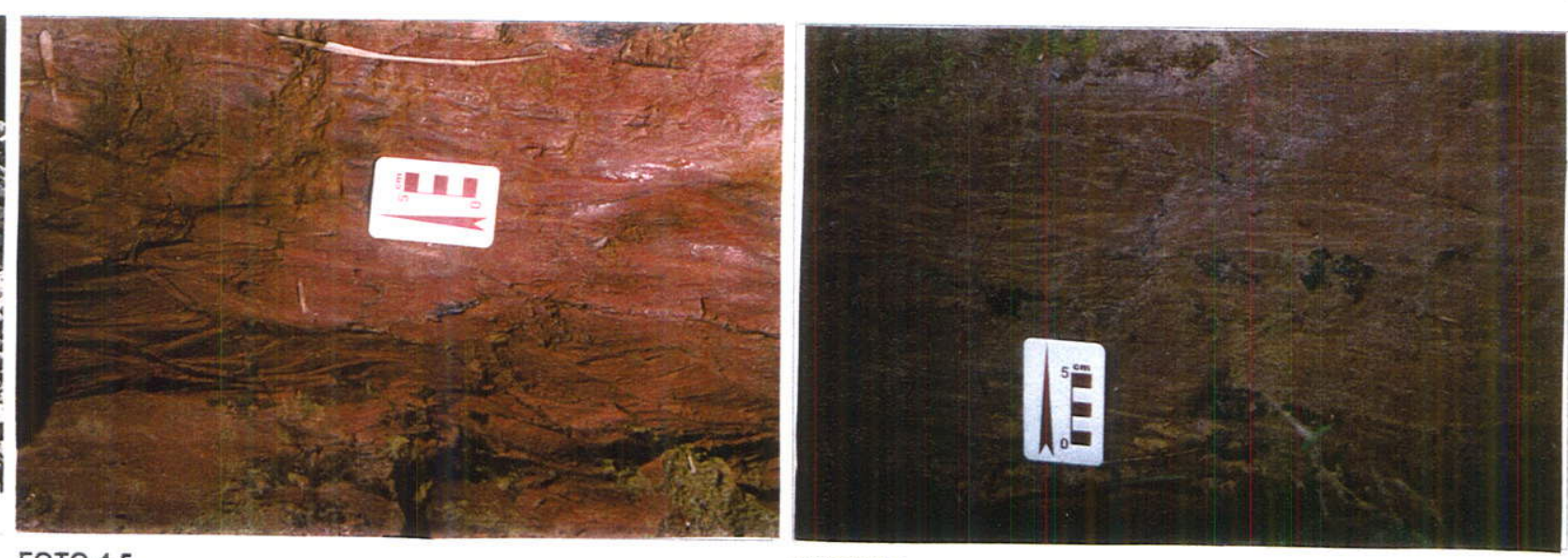

FOTO 4.6

FOTOS 4.5 e 4.6: Fácies de lamitos e ritmitos síltico-argilosos com laminações onduladas e cruzadas diversas, representando depósitos de barra de desembocadura distais em zonas de frente deltaisa divernidade Areno-Lamítica 1 da Formação Camarinha

(ponto S71, localidade de Dom Rodrigo, Área Sul - Anexo II) 

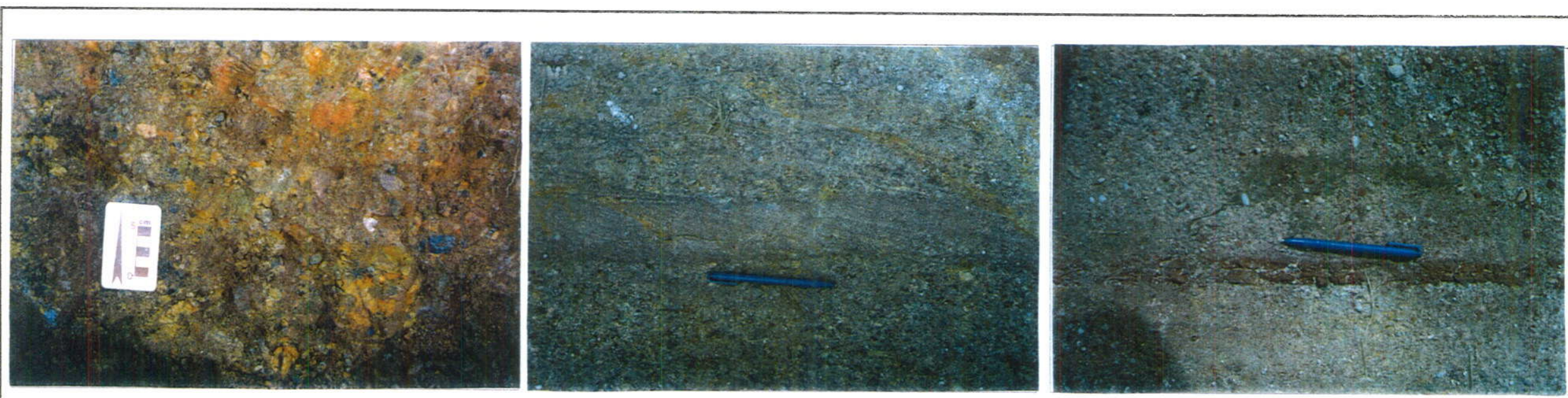

FOTO 4.7: Fácies Gmu representativa de fluxos FOTO 4.8: Fácies St e Sp representativas de flu- FOTO 4.9: Fácies Fl representativa de decantaçäo final de enchende detritos na transição Unidade Areno-Lamítica 1 - xos desconfinados característicos de sheet-floods na tes em depressōes localizadas sobre depósitos de sheet-fioods na Unidade Conglomerática 2 da Formação Camari- transição Unidade Areno-Lamítica 1 - Unidade Con- Fransaçáăa Camarinha, com intraclastos no nivel superior represen-
nha (ponto N42, localidade de Santa Cruz, Area glomerática 2 da Formação Camarinha (ponto S54, tante do fluxo seguinte (ponto $\$ 54$, localidade de OnNorte - Anexo III)

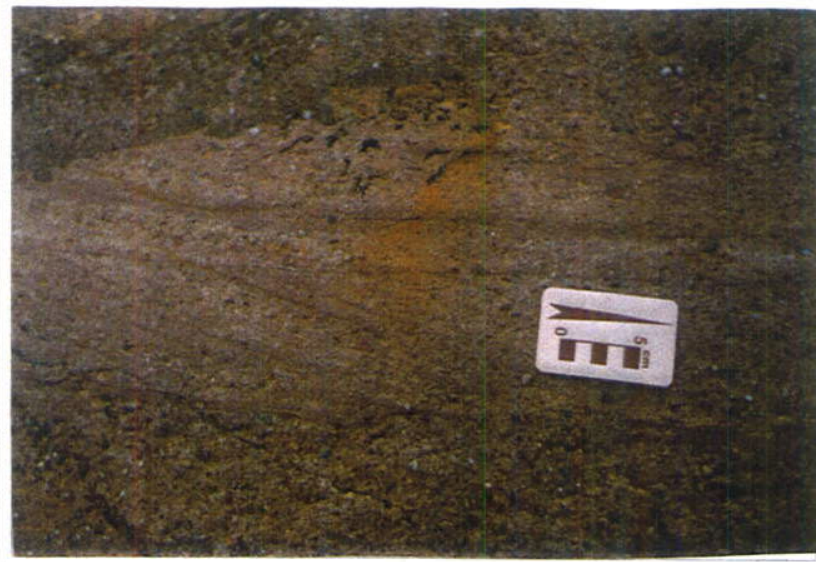

FOTO 4.10: Fácies Gh representativa de preenchimento de canais com base erosiva em depósitos de sheet-floods na transição Unidade Areno-Lamítica 1Unidade Conglomerática 2 da Formação Camarinha (ponto S54, localidade de Onça, Area Sul - Anexo II)
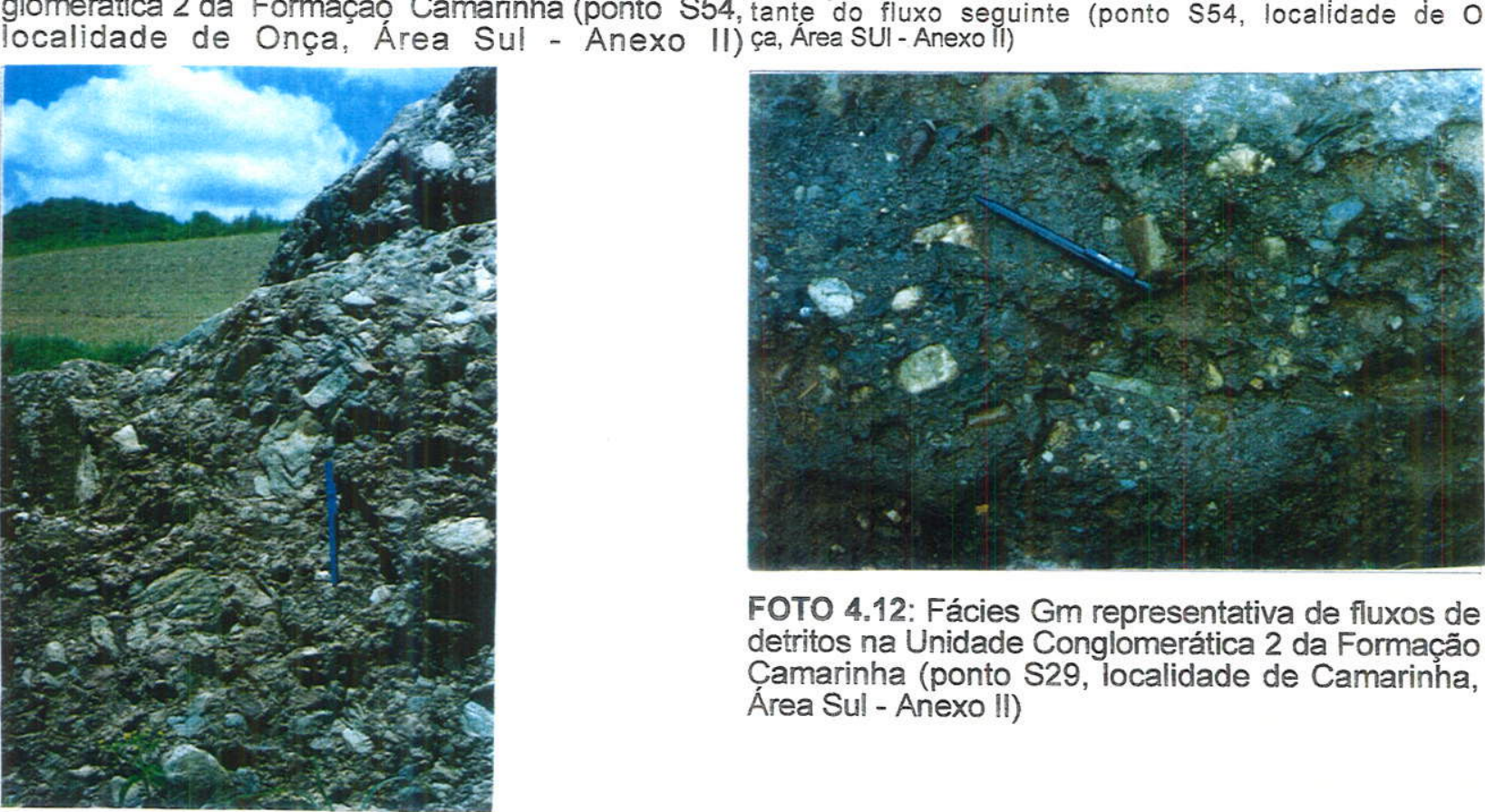

FOTO 4.12: Fácies Gm representativa de fluxos de detritos na Unidade Conglomerática 2 da Formacão Camarinha (ponto S29, localidade de Camarinha, Área Sul - Anexo II)

FOTO 4.11: Fácies $\mathrm{Gm}$ representativa de fluxos de detritos na Unidade Conglomerática 2 da Formação Camarinha (ponto S72, localidade de Varzedo, Área Sul - Anexo II) 
- Na transição da Unidade Conglomerática 2 para a Unidade Areno-Lamítica 2, observam-se novos depósitos subaquosos de fluxos gravitacionais (fácies Gmu, como nas localidades de Purunã e Camarinha, na Área Sul) (Foto 4.14), e de areias de barra de desembocadura em frente deltaica (fácies St e Sp, como nas localidades de Varzedo e Onça, Área Sul), os quais passam nas porções mais distais aos depósitos da Unidade Areno-Lamítica 2;

- Na Unidade Areno-Lamítica 2, ocorrem novos depósitos mais distais das barras de desembocadura, representados por arenitos com marcas onduladas bidirecionais (fácies $\mathrm{Sr}$, visível no Rio da Prata, Área Norte) (Foto 4.15) e ritmitos síltico-argilosos com laminações paralelas, onduladas e cruzadas, como nas localidades de Onça, Varzedo e Taquaral (Área Sul) (Foto 4.16), semelhantes aos depósitos equivalentes na Unidade Areno-Lamítica 1.

A sucessão de fácies acima descrita pode ser visualizada de acordo com o empilhamento geral das unidades constituintes da Formação Camarinha na Fig.4.3.

As associações de fácies características de depósitos de fluxos de detritos subaéreos, depósitos de sheet-floods, depósitos de fluxos gravitacionais subaquosos e depósitos de frente deltaica são representativas de sistemas de leques progradantes em um ambiente subaquoso (fandeltas), nos quais as porções subaéreas apresentam as mesmas associações faciológicas de leques aluviais, e as porções subaquosas mostram as mesmas associações faciológicas de sistemas deltaicos. Fluxos gravitacionais e correntes de turbidez podem coexistir com depósitos de frente deltaica em regiões de alto aporte sedimentar, mesmo a profundidades e gradientes mais baixos, podendo então ser igualmente submetidos a retrabalhamentos por ondas, como ocorre na Unidade Areno-Lamítica 1 nas localidades de Boqueirão, Dom Rodrigo e Felpudo, e na Unidade ArenoLamítica 2 nas localidades de Onça, Varzedo e Taquaral (Área Sul) e Rio da Prata (Área Norte). Dados os sentidos bidirecionais de paleocorrentes obtidos nesta última localidade, bem como a ocorrência de icnofósseis descritos por Ciguel et al. (1992), este retrabalhamento por ondas pode ter-se dado em ambiente marinho sujeito à ação de marés.

Um sistema idealizado de fandelta retrogradante e progradante é apresentado nas figs. $4.4 \mathrm{e}$ 4.5, com suas regiões proximal, mediana e distal e respectivos processos atuantes. Foram também indicados nessas figuras possíveis equivalentes na Formação Camarinha dos depósitos de cada região, sem se pretender, com isso, estabelecer qualquer modelo paleogeográfico, o qual será devidamente apresentado no Cap.7 deste trabalho. 


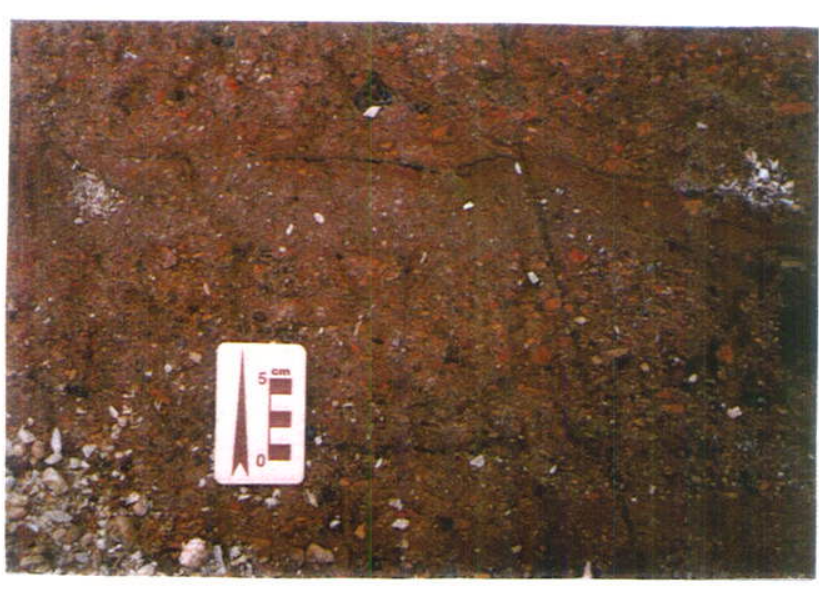

FOTO 4.13: Fácies Sh representativa de possiveis preenchimentos de canais sobre depósitos de fluxos de detritos na Unidade Conglomerática 2 da Formação Camarinha (ponto S74, localidade de Varzedo-Felpudo, Área Sul Anexo II)

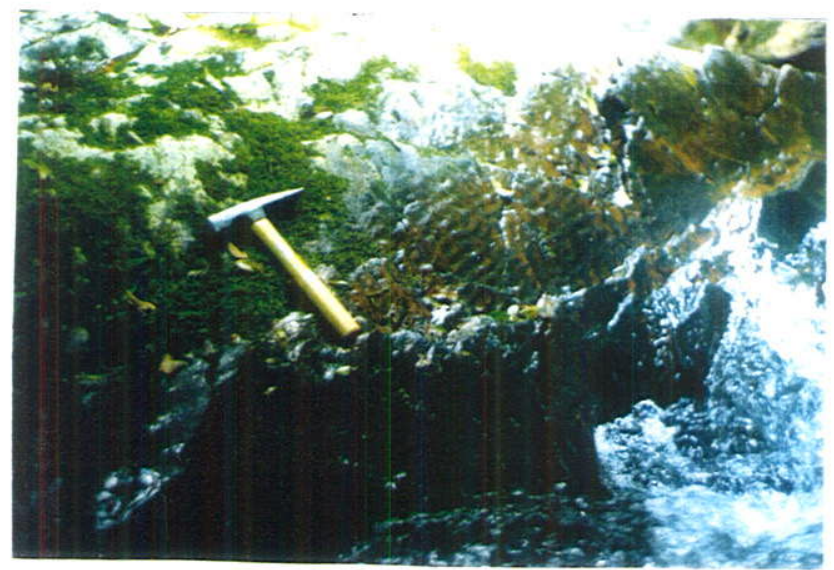

FOTO 4.15: Fácies Sr representativa de retrabalhamento por ondas bidirecionais (marés?) em depósitos arenosos de barra de desembocadura em zonas de frente deltaica na Unidade Areno-Lamítica 2 da Formaca Camarinha (ponto N51, Área Norte, Anexo III)

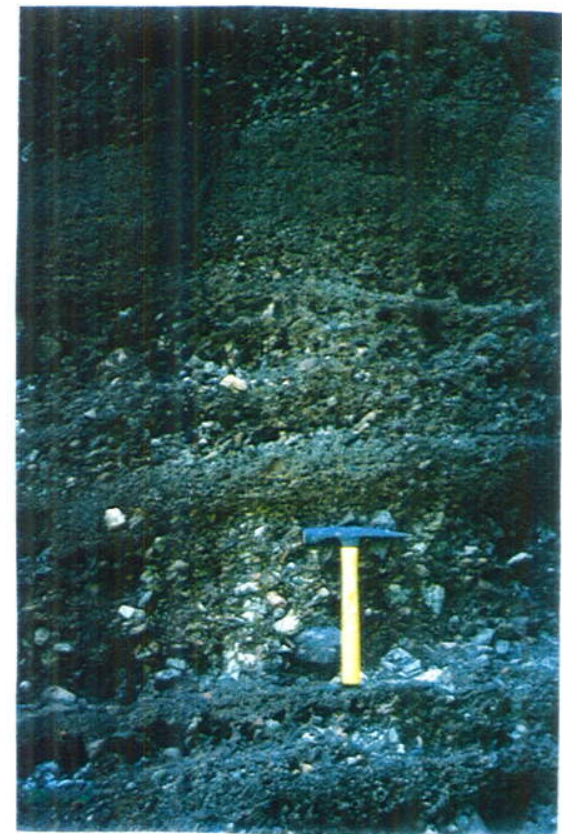

FOTO 4.14: Fácies Gmu representativa de fluxos de detritos subaquosos na transição Unidade Conglomerática 2 - Unidade Areno-L amítica 2 da Formação Camarinha (ponto S159, localidade de Purunã, Área Sul - Anexo II)

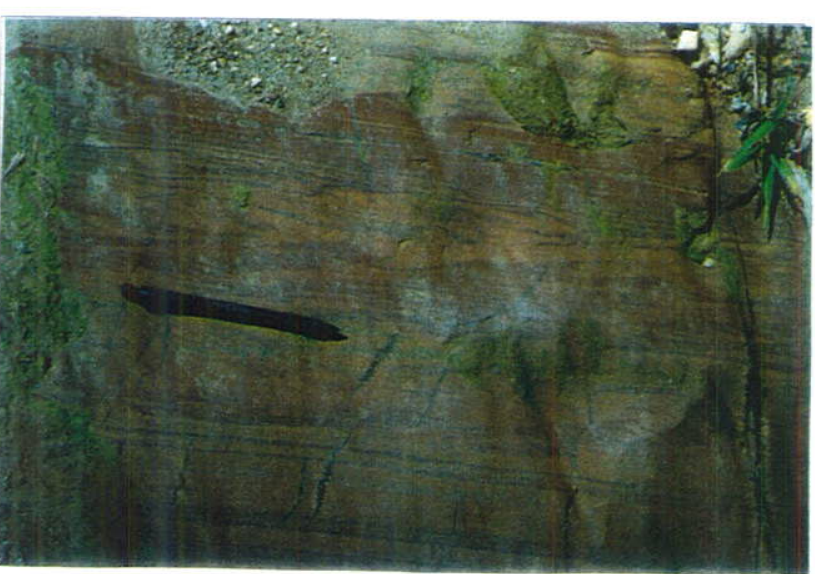

FOTO 4.16: Fácies de lamitos e ritmitos síltico-argilosos com laminações onduladas e cruzadas diversas, representando depósitos de barra de desembocadura distais em zonas de frente deltaica na Unidade Areno-Lamítica 1 da Formação Camarinha (ponto S130, localidade de Varzedo, Área Sul - Anexo II) 


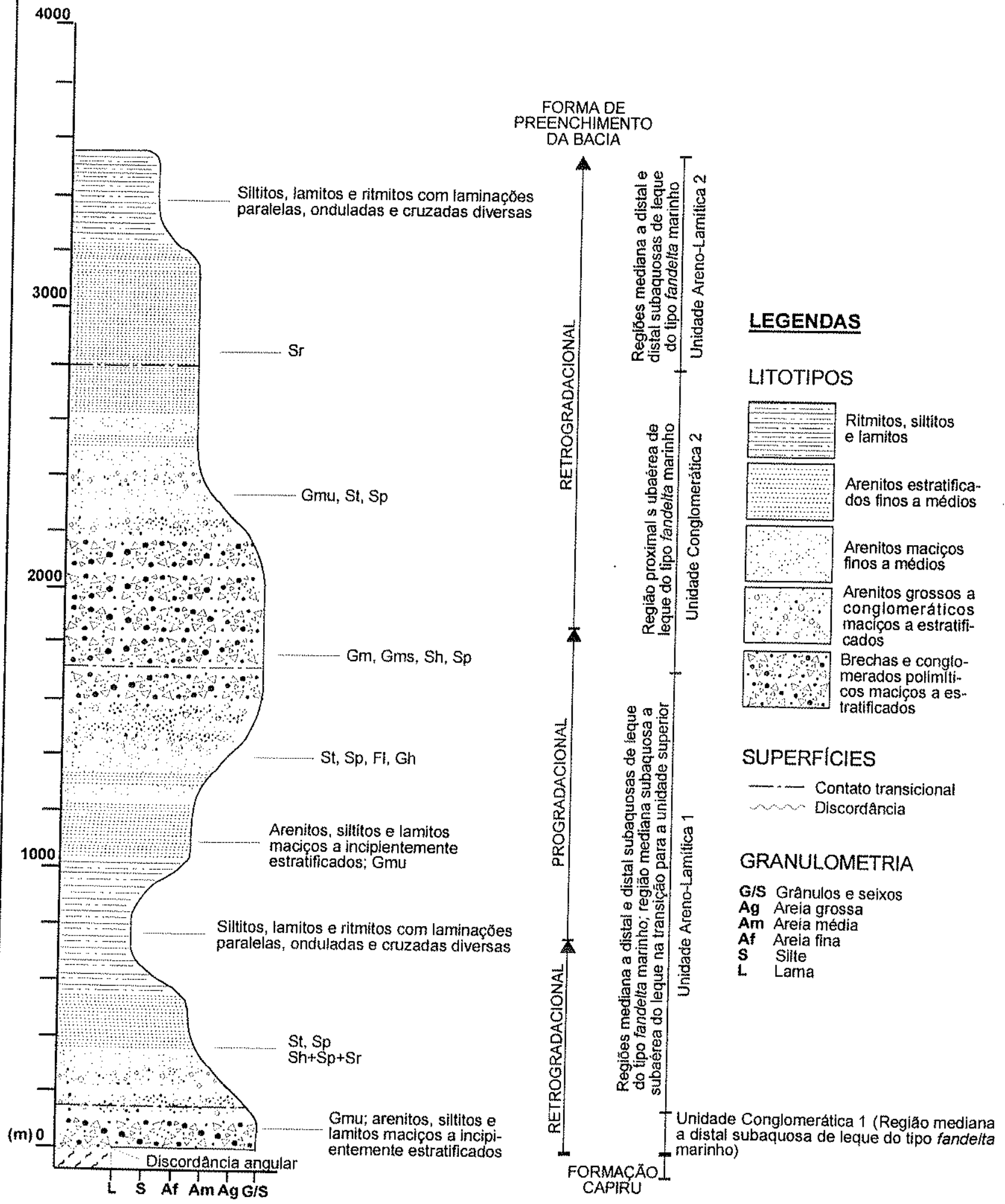

ÁREA SUL

Fig.4.3: Sucessão das litofácies identificadas na Formação Camarinha de acordo com o empilhamento geral de suas unidades constituintes (Área Sul e Area Norte); ver descrição dos códigos de litofácies no texto (págs. 85 a 90) (empilhamento baseado em levantamentos de seções locais, resultante de progradaçóes e retrogradaçōes ao longo do tempo) 


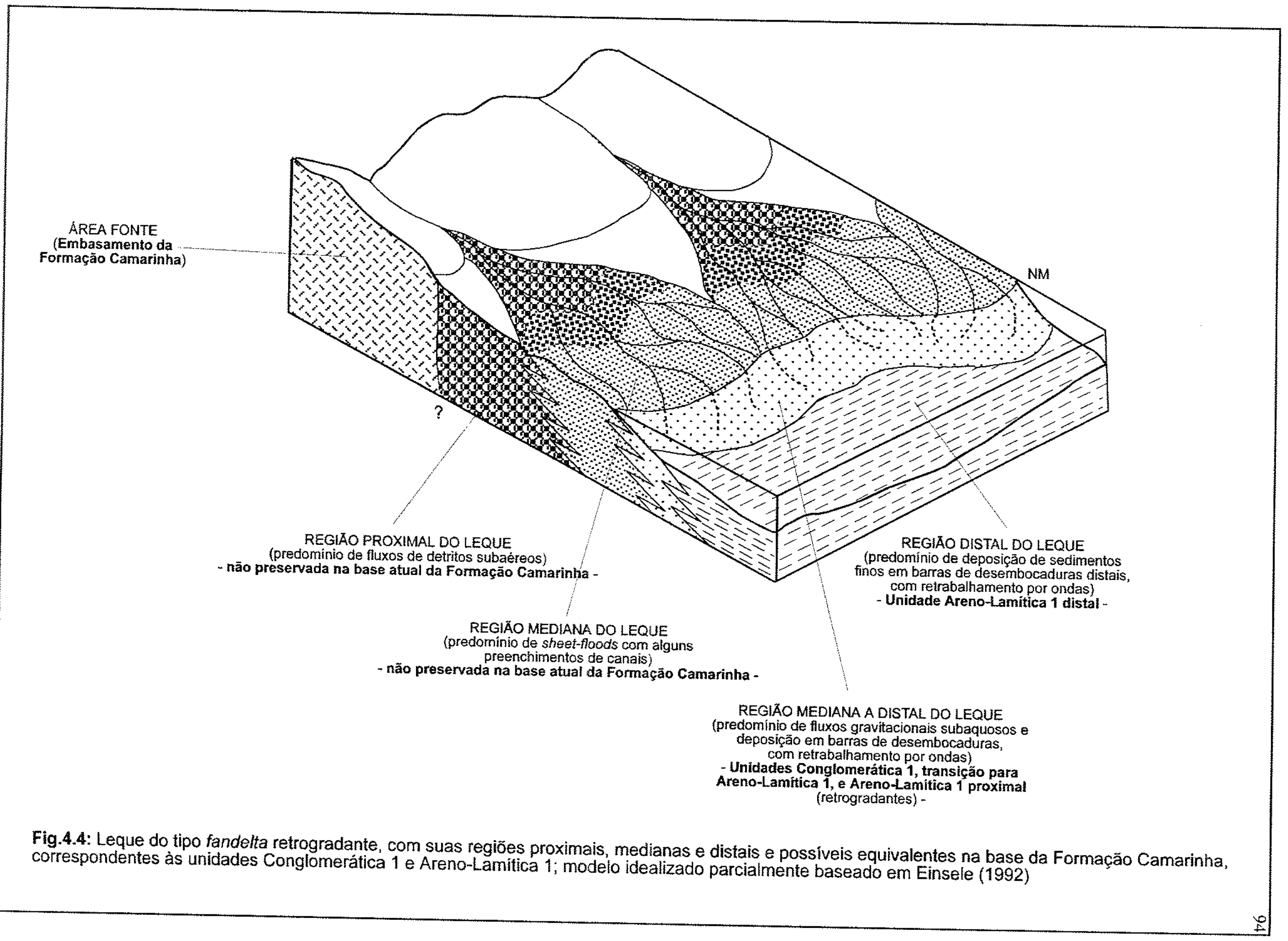




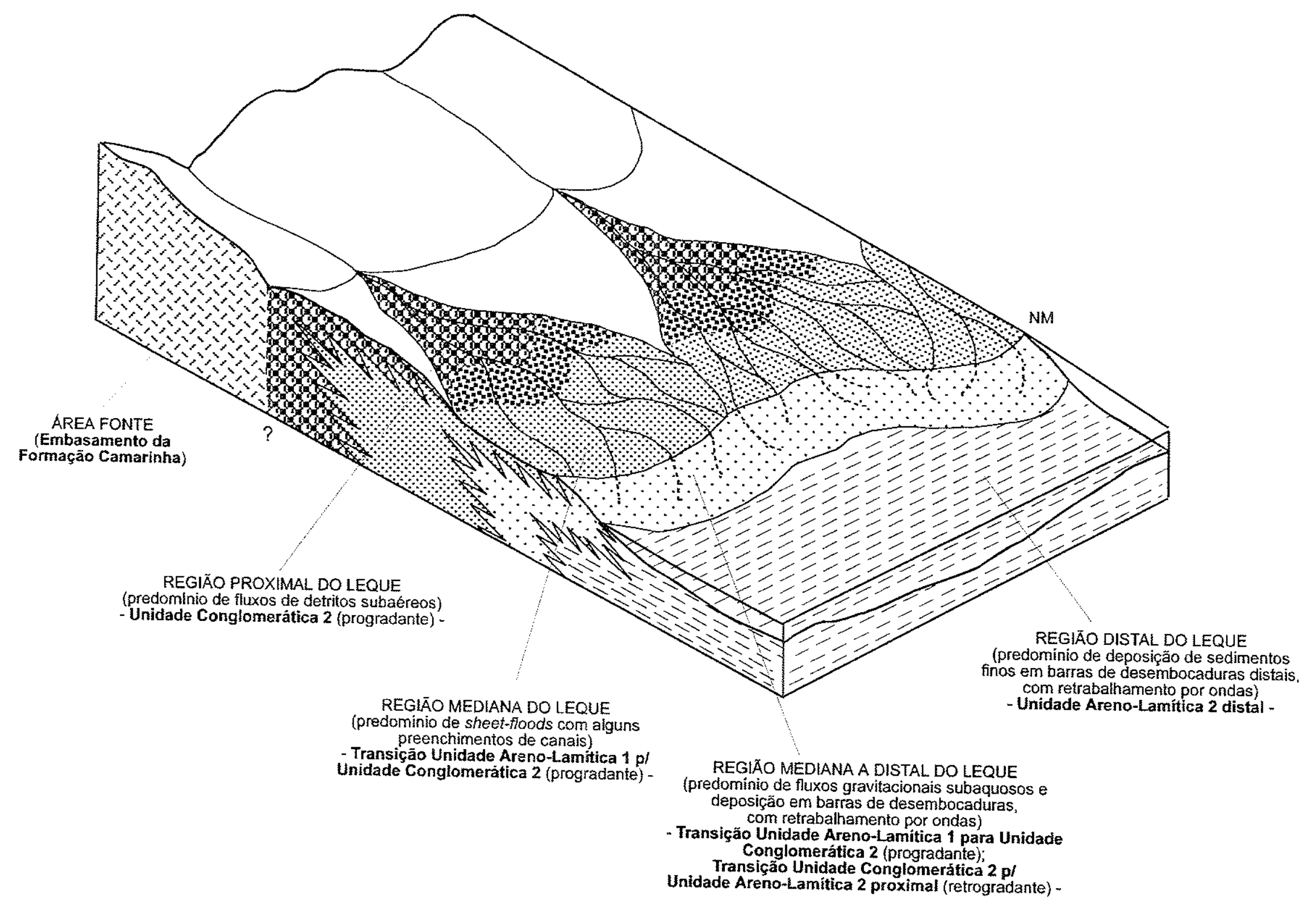

Fig.4.5: Leque do tipo fandelta progradante, com suas regiōes proximais, medianas e distais e possiveis equivalentes no topo da Formação Camarinha, correspondentes às unidades Conglomerática 2 e Areno-Lamítica 2; modelo idealizado parcialmente baseado em Einsele (1992) 


\section{FEICÕES ESTRUTURAIS}

\subsection{CARACTERÍSTICAS GERAIS}

A Formação Camarinha encontra-se preservada em duas faixas de direção NE, seguindo a estruturação geral do Cinturão Ribeira ou Região de Dobramentos Sudeste. Encontra-se dobrada na forma de sinclinais com eixos de caimento para SW, sendo que na Área Norte o sinclinal mostra nítido fechamento para NE (Mapa Geológico, Anexo I). Embora não ocorram indícios de deformação pelo sistema de cavalgamentos que afetou o embasamento da formação (como inversão e empilhamento de camadas, foliação Sc de baixo ângulo e estiramento mineral característico), a mesma mostra marcante deformação relacionada ao sistema de transcorrência da Falha da Lancinha, principalmente na Área Sul, que é cortada pela zona de cisalhamento principal. A Área Norte encontra-se apenas tangenciada pela Falha de Morro Agudo e uma subsidiária desta, que controla o vale do Rio dos Matos, não apresentando feições deformacionais tão evidentes.

Os principais lineamentos da região são nitidamente visíveis em fotografias aéreas e imagens de satélite, na forma de alinhamentos de elementos texturais, controle estrutural de vales e truncamentos das unidades. As principais estruturas regionais presentes são mostradas nas Figs. 5.1 e 5.2 .

A atuação dos falhamentos transcorrentes gerou estruturas como basculamentos de camadas, truncamentos de pacotes litológicos, dobramentos escalonados, clivagens de fraturas com eventual desenvolvimento de foliação plano-axial, fraturamentos diversos e estiramentos de clastos nas rochas da Formação Camarinha. Essas feições ocorrem predominantemente na Área Sul e são raras ou ausentes na Área Norte, com exceção dos dobramentos escalonados. Serão descritas e analisadas a seguir.

\section{2. ÁREA NORTE}

\subsubsection{Estruturas Dúcteis}

O estereograma de medidas de acamamentos da Área Norte é mostrado na Fig.5.3. Nesta área, as medidas mostram concentrações máximas em torno de $\mathrm{N} 80^{\circ} \mathrm{W} / 40^{\circ} \mathrm{SW}(22,22 \%)$, $\mathrm{N} 20^{\circ} \mathrm{E} / 45^{\circ} \mathrm{NW}(4,44 \%)$ e $\mathrm{N} 52^{\circ} \mathrm{E} /$ subvertical $(4,44 \%)$. Em campo, os mergulhos convergem para o interior da área e as estruturas sedimentares presentes indicam topos de camadas em posição normal, configurando-se assim um sinclinal com fechamento para NE (onde as camadas mostram a orientação em torno de $\mathrm{N} 80^{\circ} \mathrm{W}$ ) e eixo $\mathrm{S} 56^{\circ} \mathrm{W} / 24^{\circ}$ (pólo da guirlanda). A orientação desse eixo mostramse oblíqua à direção geral da Falha de Morro Agudo e sua subsidiária que controla o vale do 


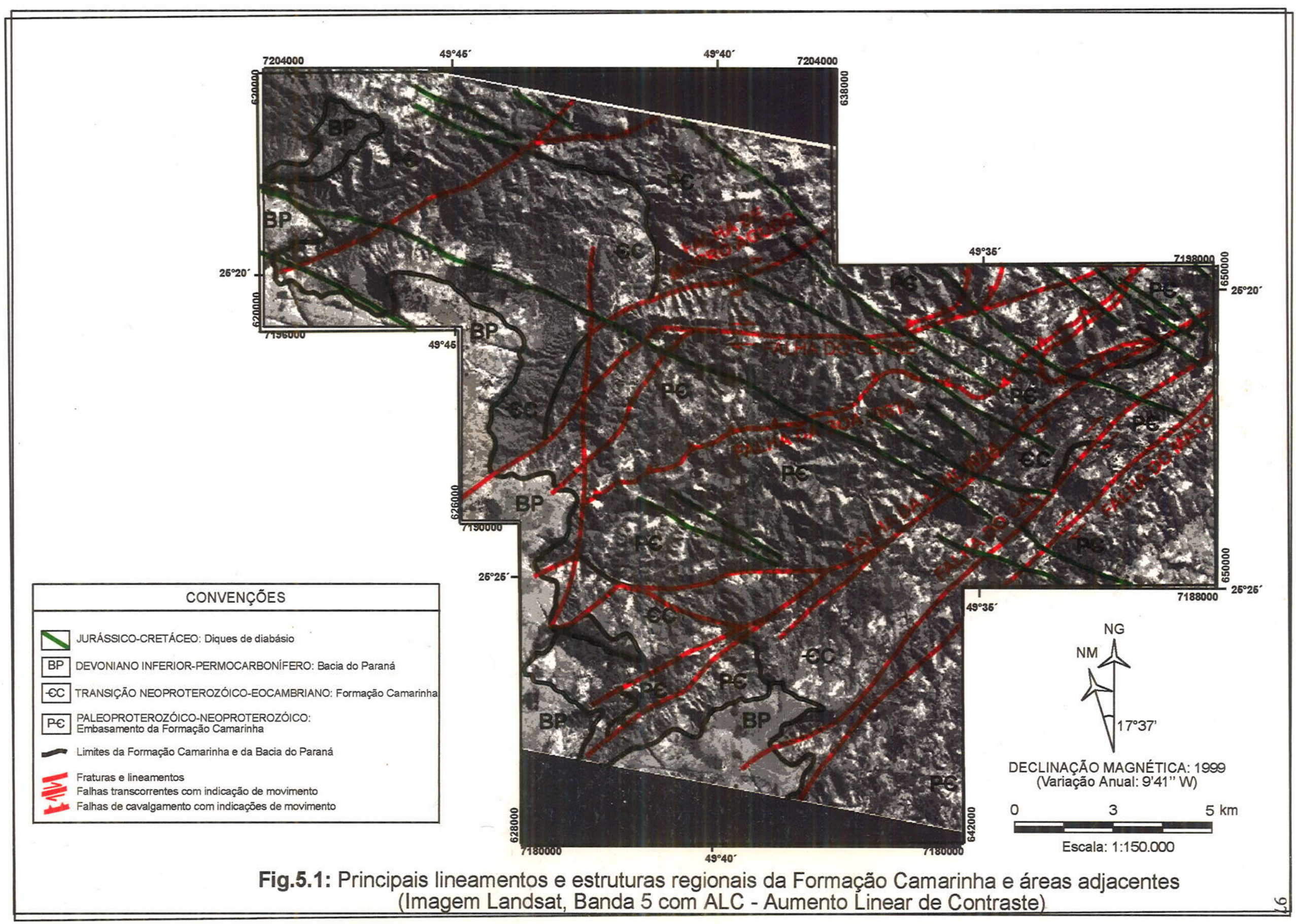




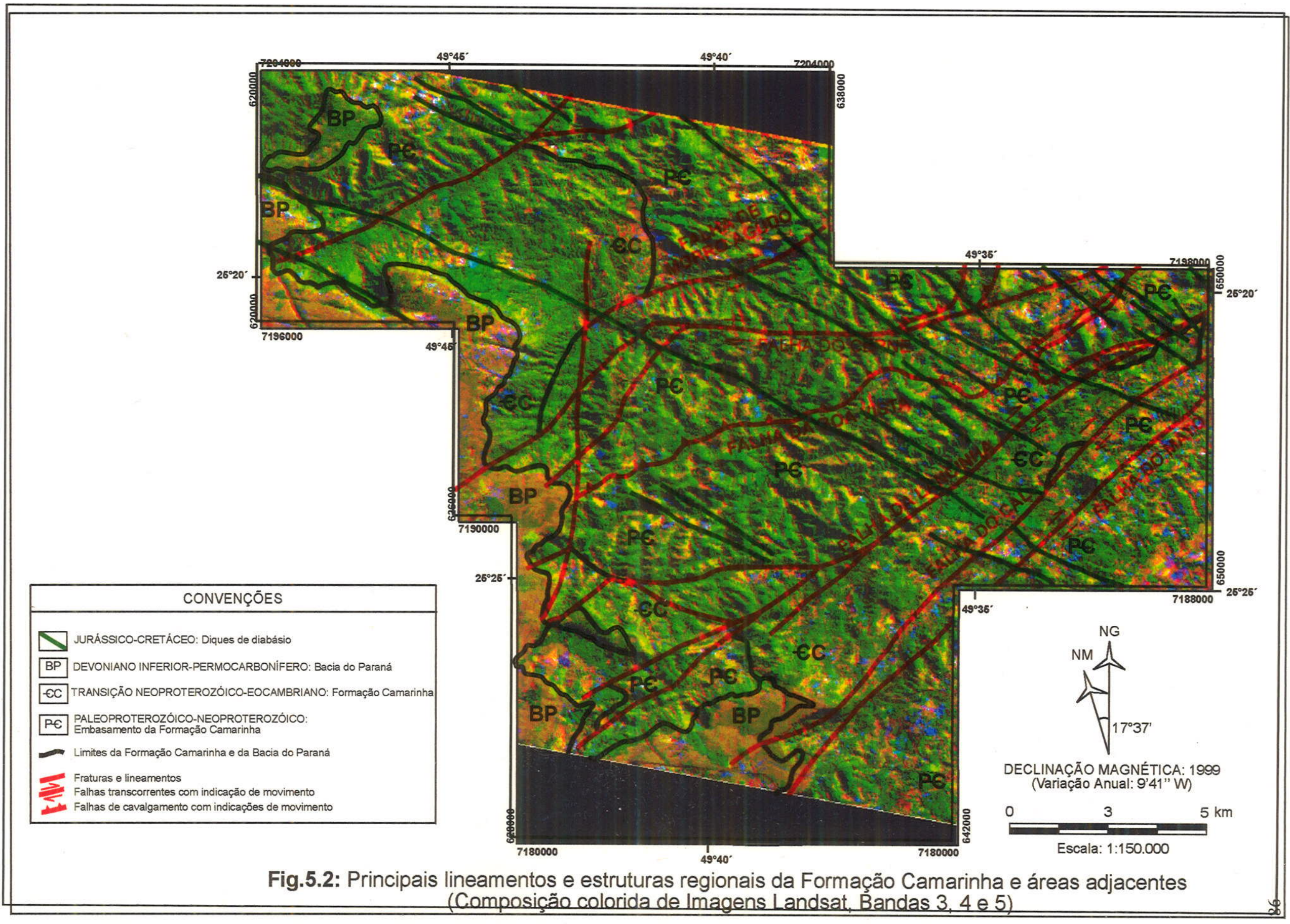




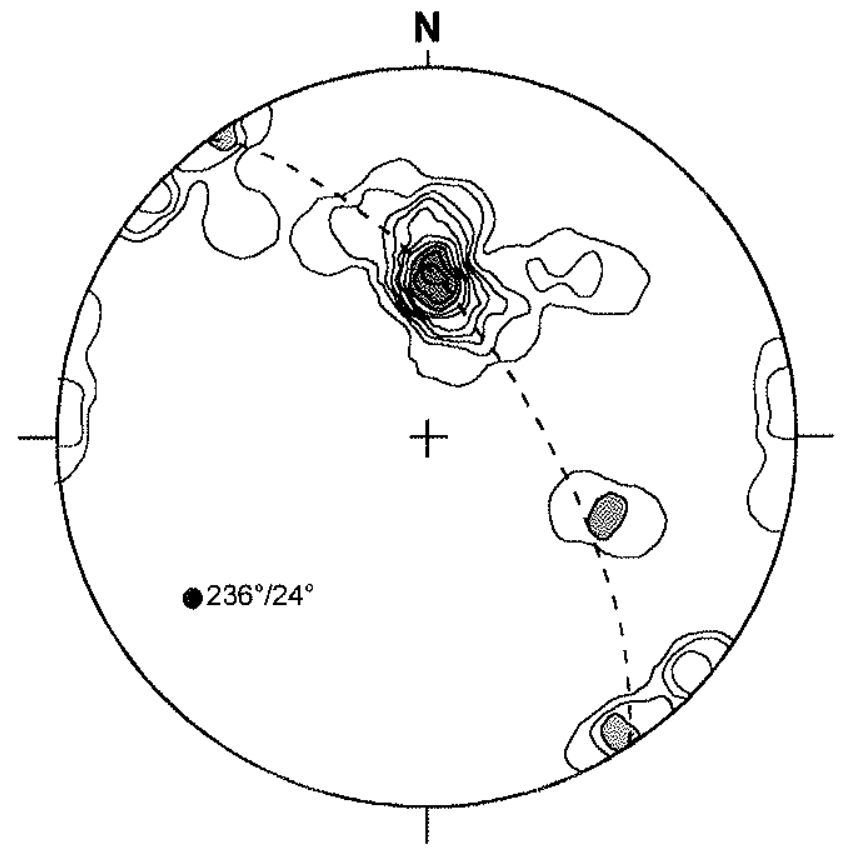

MÁXIMIOS:

PONTOS: 49

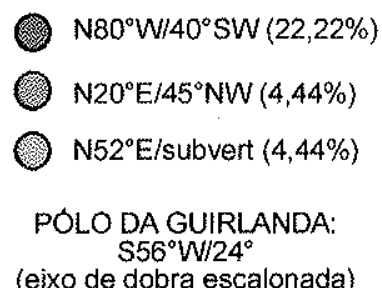

ISOCURVAS:

$2,04 \%$

$4,08 \%$

$6,12 \%$

$8,16 \%$

$10,20 \%$

$12,24 \%$

$14,29 \%$

$16,33 \%$

$18,37 \%$

(eixo de dobra escalonada)

$20,41 \%$

Fig.5.3: Estereograma de acamamentos (So) da Formação Camarinha na Área Norte, mostrando dobramento aberto com plano axial de direção $\mathrm{N} 56^{\circ} \mathrm{E}$, caimento de eixo para $\$ 56^{\circ} \mathrm{W}$ e camadas verticalizadas devido à proximidade com zonas de falhamentos transcorrentes (Falha de Morro Agudo) 
Rio dos Matos na região (em torno de $\mathrm{N} 60-70^{\circ} \mathrm{E}$ ), configurando uma estrutura escalonada relacionada a um deslocamento lateral direito.

Na Área Norte, não foi possível obter medidas de atitudes de fraturamentos e foliação cataclástica em quantidade suficiente para uma análise representativa, sendo portanto aqui apresentados apenas os dados referentes à Área Sul.

\section{3. ÁREA SUL}

\subsubsection{Estruturas Dúcteis}

$\mathrm{Na}$ Área Sul, as medidas de acamamentos mostram grande dispersão de máximos, devido à superposição de estruturas distintas com comportamentos diferentes ao norte e ao sul da Falha da Lancinha. Conforme observado em campo, ao norte da Falha da Lancinha, em um bloco delimitado pela mesma a sudeste e por uma falha sintética associada ao norte (abrangendo as localidades de Purunã, Camarinha, Graciosa e parte de Taquaral), os acamamentos mostram-se aproximadamente paralelos à direção da falha sintética, com direções próximas a E-W e mergulhos para sul, variando de $45^{\circ}$ a $88^{\circ}$. Já ao sul da Falha da Lancinha, em um bloco delimitado pela mesma a noroeste e pela Falha do Cal a sudeste (abrangendo o restante da formação), os acamamentos mostram-se direcionados predominantemente para NE, acompanhando o traço principal da falha e mergulhando para NW, quando próximos à Falha do Cal, e para $\mathrm{SE}$ ou verticalmente quando próximos à Falha da Lancinha propriamente dita (Mapa Geológico, Anexo I). Assim, em função dessas diferença de comportamento, optou-se por tratar distintamente as estruturas da Área Sul situadas nestes dois blocos, gerando-se os estereogramas apresentados nas Figs. 5.4 e 5.5.

Os dados de acamamentos no bloco ao sul da Falha da Lancinha evidenciam uma marcante estruturação com trend $\mathrm{NE}$, apresentando concentrações máximas em torno de $\mathrm{N} 50^{\circ} \mathrm{E} / 45^{\circ} \mathrm{NW}$

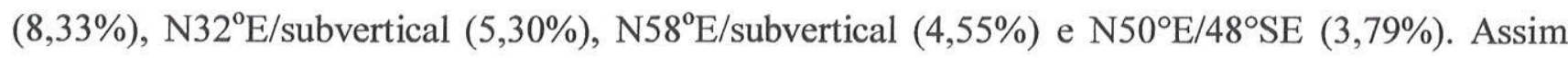
como na Área Norte, observou-se em campo que os mergulhos convergem para o interior da área e as estruturas sedimentares presentes indicam topos de camadas em posição normal, constituindo um sinclinal semifechado com eixo aproximadamente $\mathrm{S} 60^{\circ} \mathrm{W}-6^{\circ}$. Embora essa direção seja paralela ao traço principal da Falha da Lancinha $\left(\mathrm{N} 50^{\circ}-70^{\circ} \mathrm{E}\right)$, pode-se considerar esse dobramento também como uma estrutura escalonada relacionada à atuação da mesma, uma vez que estruturas escalonadas tendem a paralelizar-se à zona de cisalhamento transcorrente quanto mais próximas à mesma. Além disso, variações locais nas direções de acamamento (observadas em campo, como nas localidades de Felpudo e Varzedo, e na concentração N32 E/subvertical do estereograma da Fig.5.4 parecem indicar pequenas inflexões desse dobramento, gerando uma guirlanda secundária com pólo 


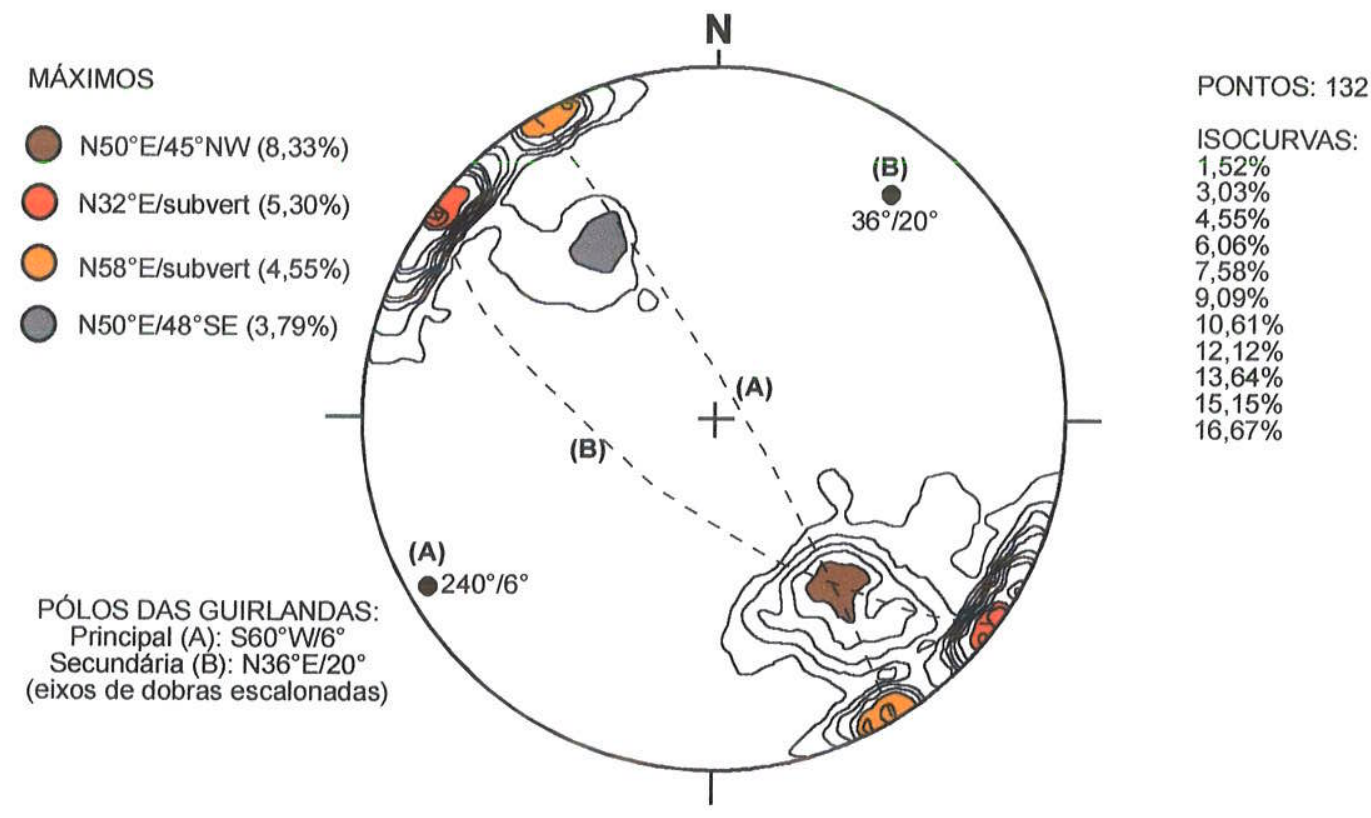

Fig.5.4: Estereograma de acamamentos (So) da Formaçăo Camarinha na Área Sul (bloco ao sul da Falha da Lancinha) , mostrando dobramento com plano axial de direçáo $\mathrm{N} 50-60^{\circ} \mathrm{E}$, caimento de eixo principal para $\mathrm{S} 60^{\circ} \mathrm{W}$ e secundário para $\mathrm{N} 36^{\circ} \mathrm{E}$, e camadas verticalizadas devido à proximidade com zonas de falhamentos transcorrentes (falhas da Lancinha e do Cal)

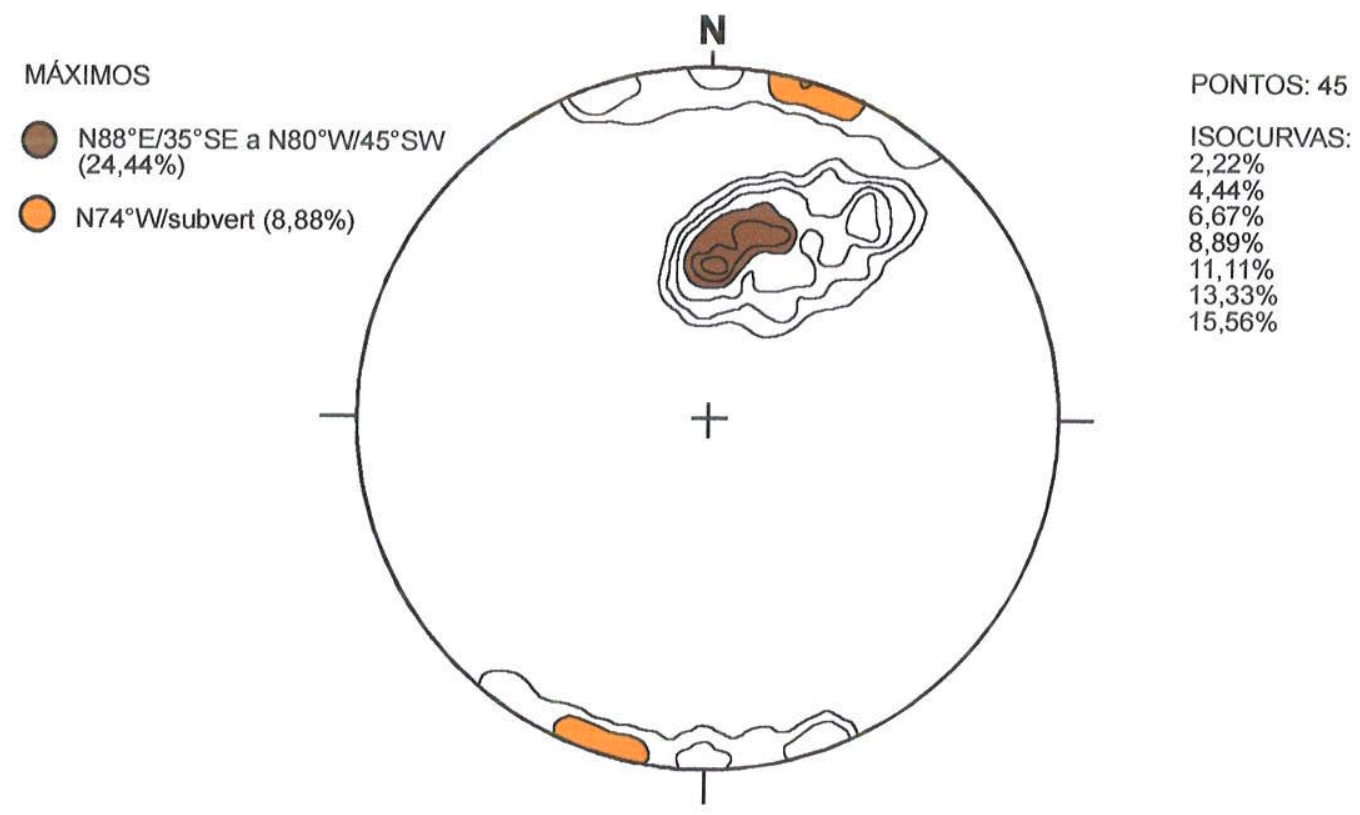

Fig.5.5: Estereograma de acamamentos (So) da Formação Camarinha na Área Sul (bloco ao norte da Falha da Lancinha) , mostrando estrutura cônica de direção $\mathrm{N} 74^{\circ} \mathrm{W}$ a N88 $\mathrm{E}$, sem relaçăo com os dobramentos escalonados 
$\mathrm{N} 36^{\circ} \mathrm{E} / 20^{\circ}$, representativa dos pontos em que o eixo estaria em posição oblíqua à direção principal da Falha da Lancinha e caracterizando um deslocamento lateral direito para a mesma.

Já no bloco ao norte da Falha da Lancinha (Fig.5.5), as concentrações máximas ocorrem em torno de $\mathrm{N} 88^{\circ} \mathrm{E} / 35^{\circ} \mathrm{SE}$ a $\mathrm{N} 80^{\circ} \mathrm{W} / 45^{\circ} \mathrm{SW}(24,44 \%)$ e $\mathrm{N} 74^{\circ} \mathrm{W} /$ subvertical $(8,88 \%)$. O conjunto configura uma estruturação cônica aparentemente sem relação com a estruturação verificada ao sul do lineamento e menos evidente do que esta última, podendo constituir uma feição resultante de arrasto do flanco noroeste da dobra escalonada ao longo da Falha da Lancinha por ocasião de uma reativação lateral esquerda da mesma, já detectada anteriormente por diversos autores.

As relações das atitudes de acamamentos nas áreas Norte e Sul com os eixos das dobras escalonadas podem ser visualizadas na Fig.5.6.

\subsubsection{Estruturas rúpteis}

$\mathrm{Na}$ Área Sul da Formação Camarinha, as estruturas rúpteis são representadas principalmente por fraturamentos diversos nas quatro unidades constituintes (às vezes deslocando camadas com rejeitos centimétricos a decimétricos, mais raramente apresentando estrias de atrito), e eventualmente clivagens de fraturas nos pacotes sílticos e lamíticos. Essas estruturas são visíveis em fotografias aéreas e imagens de satélite, gerando brechação das rochas onde ocorrem e, na região da Falha da Lancinha, marcante estiramento de clastos de conglomerados e brechas da Unidade Conglomerática 2, estiramento este que será devidamente analisado no item 5.3.3. deste capítulo.

O estereograma de fraturas da Área Sul da Formação Camarinha (Fig.5.7) mostra diversas concentrações máximas, representando as seguintes estruturas:

1. $\mathrm{N} 55^{\circ} \mathrm{E} /$ subvertical $(6,9 \%)$, podendo variar a até $\mathrm{N} 64^{\circ} \mathrm{E}(4,8 \%)$. Em campo, observou-se estria de atrito com atitude $\mathrm{N} 55^{\circ} \mathrm{E} / 4^{\circ}$ associada a este sistema (Foto 5.1). Esses planos apresentam localmente mergulhos mais baixos $\left(65^{\circ} \mathrm{NW}\right)$, ressaltos e estrias de atrito $\mathrm{N} 50^{\circ} \mathrm{W} / 55^{\circ}$ indicativas de deslocamento normal (Foto 5.2). Além dos ressaltos e estrias, esta estrutura gera brechação de rochas, estiramento de clastos na região da Falha da Lancinha, e alinhamentos de elementos texturais visíveis em fotografias aéreas e imagens de satélites;

2. $\mathrm{N} 76^{\circ} \mathrm{W} /$ subvertical $(6,9 \%)$ e $\mathrm{N} 86^{\circ} \mathrm{E} /$ subvertical $(7,3 \%)$, mostrando localmente deslocamentos com rejeitos centimétricos a decimétricos de camadas da Unidade Areno-Lamítica 1 e sua transição para a Unidade Conglomerática 2 (Foto 5.3). Também são visíveis em fotografias aéreas e imagens de satélite, com seu alinhamento, no entanto, sendo eventualmente truncado pela estrutura anteriormente descrita $\left(\mathrm{N} 55^{\circ} \mathrm{E} /\right.$ subvertical); 


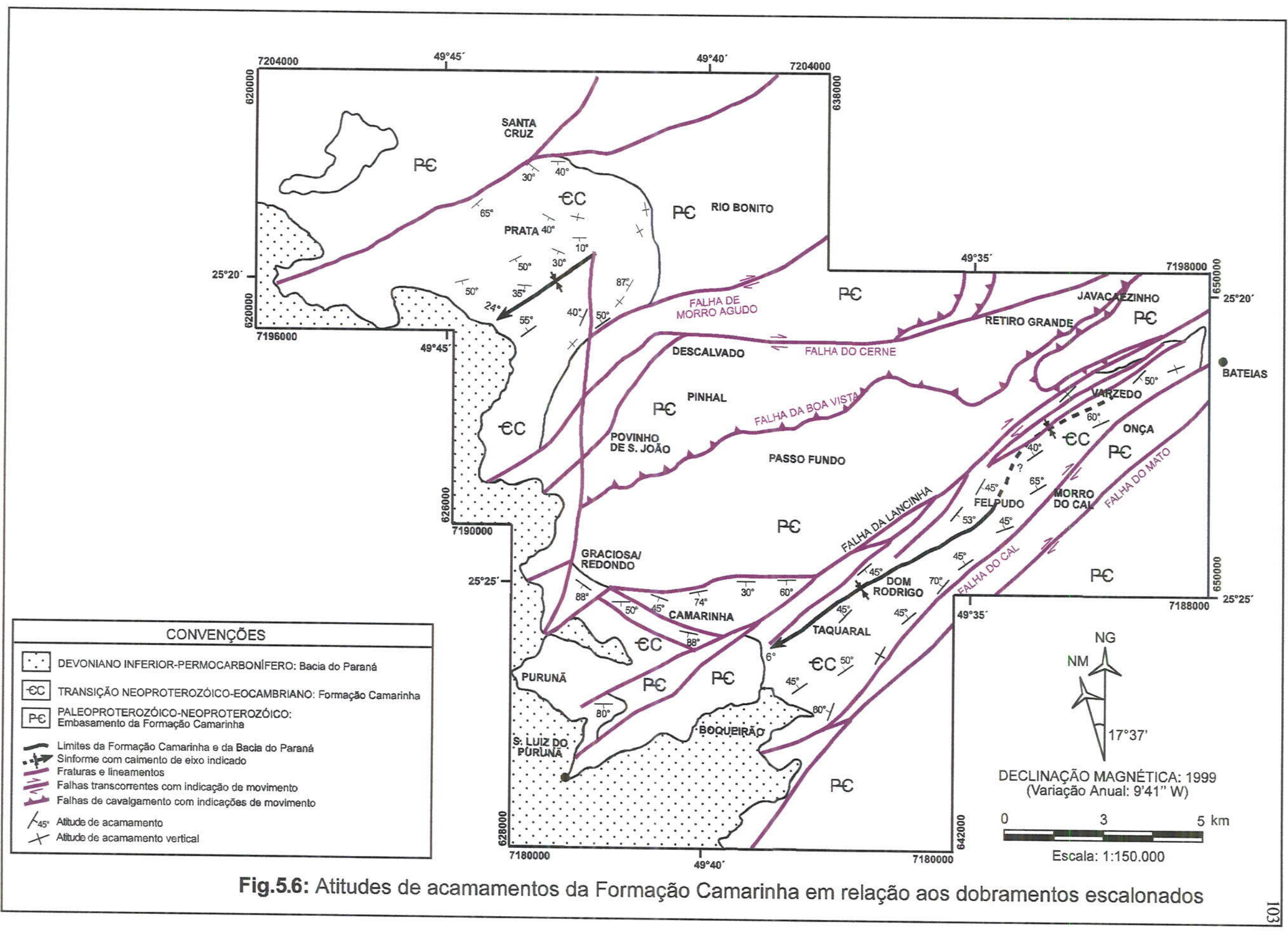




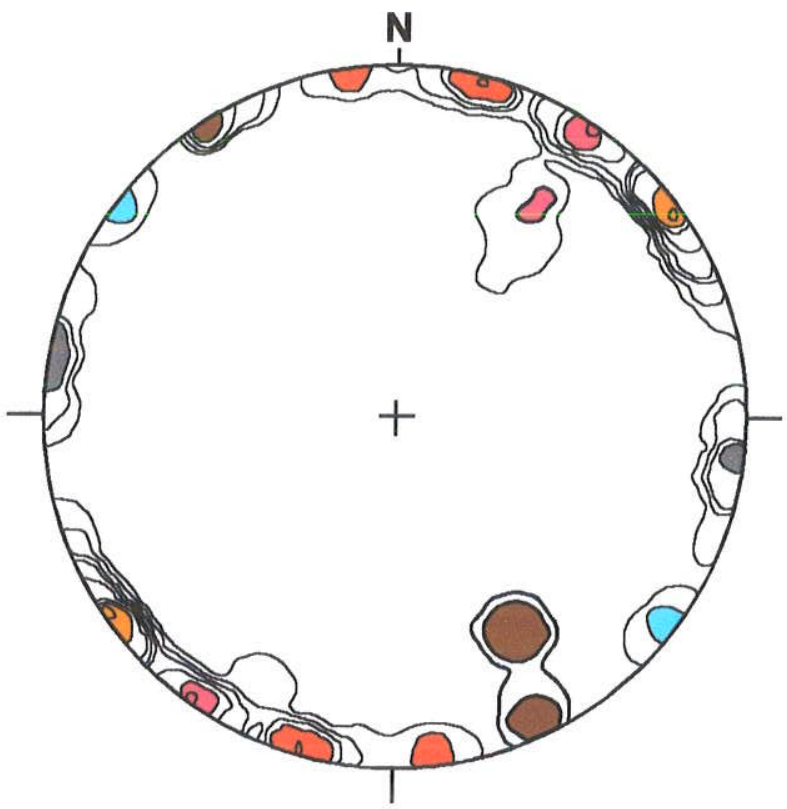

PONTOS: 82

ISOCURVAS:
$1,22 \%$
$2,44 \%$
$3,66 \%$
$4,88 \%$
$6,10 \%$
$7,32 \%$
$8,54 \%$
$9,76 \%$
$10,98 \%$

MÁXIMOS:

$\mathrm{N} 55^{\circ} \mathrm{E} /$ subvert $(6,9 \%)$ e $\mathrm{N} 64^{\circ} \mathrm{E} /$ subvert a $65^{\circ} \mathrm{NW}(4,8 \%)$

(Zona de cisalhamento transcorrente principal da Falha da Lancinha)

N76 ${ }^{\circ}$ W/subvert $(6,9 \%)$ e N86 ${ }^{\circ}$ E/subvert $(7,3 \%)$

(Fraturas sintéticas associadas ao sistema da Falha da Lancinha)

$\mathrm{N} 35^{\circ} \mathrm{W} /$ subvert $(8,3 \%)$

(Fraturas antitéticas associadas ao sistema da Falha da Lancinha)

N55 W/subvert (8,3\%)

(Fraturas T associadas ao sistema da Falha da Lancinha)

N08 ${ }^{\circ}$ E/subvert $(4,16 \%)$

(Fraturas $\mathrm{X}$ associadas ao sistema da Falha da Lancinha)

N34 $4^{\circ}$ E/subvert $(2,77 \%)$

(Clivagem de fratura associada a dobra escalonada do sistema da Falha da Lancinha)

Fig.5.7: Estereograma de medidas de fraturas da Formação Camarinha (Área Sul), mostrando estruturas rúpteis associadas à zona de cisalhamento transcorrente da Falha da Lancinha, como

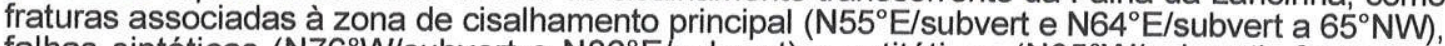
falhas sintéticas ( $176^{\circ} \mathrm{W} /$ subvert e $\mathrm{N} 86^{\circ} \mathrm{E} /$ subvert) e antitéticas (N35 $\mathrm{W} / \mathrm{subvert}$ ), fraturas T

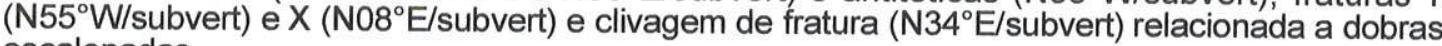
escalonadas 
3. $\mathrm{N} 35^{\circ} \mathrm{W} /$ subvertical $(8,3 \%)$, variando a até $\mathrm{N} 30^{\circ} \mathrm{W}$ e $\mathrm{N} 45^{\circ} \mathrm{W}$. Esta estrutura é menos evidente, tanto em fotografias aéreas e imagens de satélite como em campo, sendo representada apenas por fraturamentos locais com pouca ou nenhuma brechação ou deslocamento associados;

4. $\mathrm{N} 55^{\circ} \mathrm{W} /$ subvertical $(8,3 \%)$, podendo variar a até $\mathrm{N} 68^{\circ} \mathrm{W}$ com mergulhos de até $40^{\circ}$. Estas estruturas podem apresentar caráter distensivo, evidenciado por feições de deslocamento normal, como ressaltos e estria de atrito $\mathrm{S} 85^{\circ} \mathrm{W} / 30^{\circ}$ (Foto 5.4), e preenchimento por veios de quartzo. Em fotografias aéreas e imagens de satélite, mostram-se freqüentemente preenchidas por diques de diabásio intrudidos no Mesozóico;

5. $\mathrm{N} 08^{\circ} \mathrm{E} /$ subvertical $(4,16 \%)$, também pouco evidente, sendo predominantemente representada por fraturamentos locais com pouca ou nenhuma brechação ou deslocamento associados. Em fotografias aéreas e imagens e satélite, mostra-se às vezes representada por alinhamentos locais de elementos texturais, sendo o mais marcante desses alinhamentos na região oeste da área estudada, limitando parte da Área Sul da Formação Camarinha com seu embasamento, e controlando parte do vale do Rio Açungui mais ao norte;

6. $\mathrm{N} 34^{\circ} \mathrm{E} / \mathrm{subvertical}(2,77 \%)$, ocorrendo na forma de uma clivagem de fratura em sedimentos mais finos da Unidade Areno-Lamítica 1 (Foto 5.5), mostrando-se paralela ao eixo de dobras escalonadas $\mathrm{N} 36^{\circ} \mathrm{E} / 20^{\circ}$ descrito no item 5.3.1 deste capítulo.

O conjunto dessas estruturas, as estrias de atrito presentes, as relações angulares das estruturas entre si e a disposição das mesmas em fotografias aéreas e imagens de satélite permitem interpretá-las como representativas, respectivamente, de:

1. $\mathrm{N} 55^{\circ} \mathrm{E} /$ subvertical a $\mathrm{N} 64^{\circ} \mathrm{E}$ : falhamento principal (Falha da Lancinha), sendo os ressaltos e estrias de atrito indicativos de deslocamento normal possivelmente relacionados a reativações distensivas deste sistema no Paleozóico;

2. $\mathrm{N} 76^{\circ} \mathrm{W} / \mathrm{subvertical} \mathrm{e} \mathrm{N} 86^{\circ} \mathrm{E} /$ subvertical: falhas sintéticas associadas ao sistema principal, com sentido de deslocamento lateral direito compatível;

3. $\mathrm{N} 35^{\circ} \mathrm{W} /$ subvertical a $\mathrm{N} 30^{\circ} \mathrm{W}$ e $\mathrm{N} 45^{\circ} \mathrm{W}$ : falhas antitéticas associadas ao sistema principal;

4. $\mathrm{N} 55^{\circ} \mathrm{W} /$ subvertical a $N 68^{\circ} \mathrm{W}$ com mergulhos de até $40^{\circ}$ : fraturas $\mathrm{T}$, com caráter de juntas de tração, posteriormente preenchidas por diques de diabásio no Mesozóico;

5. $\mathrm{N} 08^{\circ} \mathrm{E} / \mathrm{subvertical:} \mathrm{fraturas} \mathrm{X}$;

6. $\mathrm{N} 34^{\circ} \mathrm{E} /$ subvertical: clivagem de fratura relacionada aos dobramentos escalonados, os quais, como referido anteriormente no item 5.3.1 deste capítulo, apresenta pequenas variações na direção de seu eixo.

O caráter anastomosado das zonas de cisalhamento e estruturas associadas, bem como fenomenos de rotação já detectados anteriormente em outros trabalhos na região, podem ser 

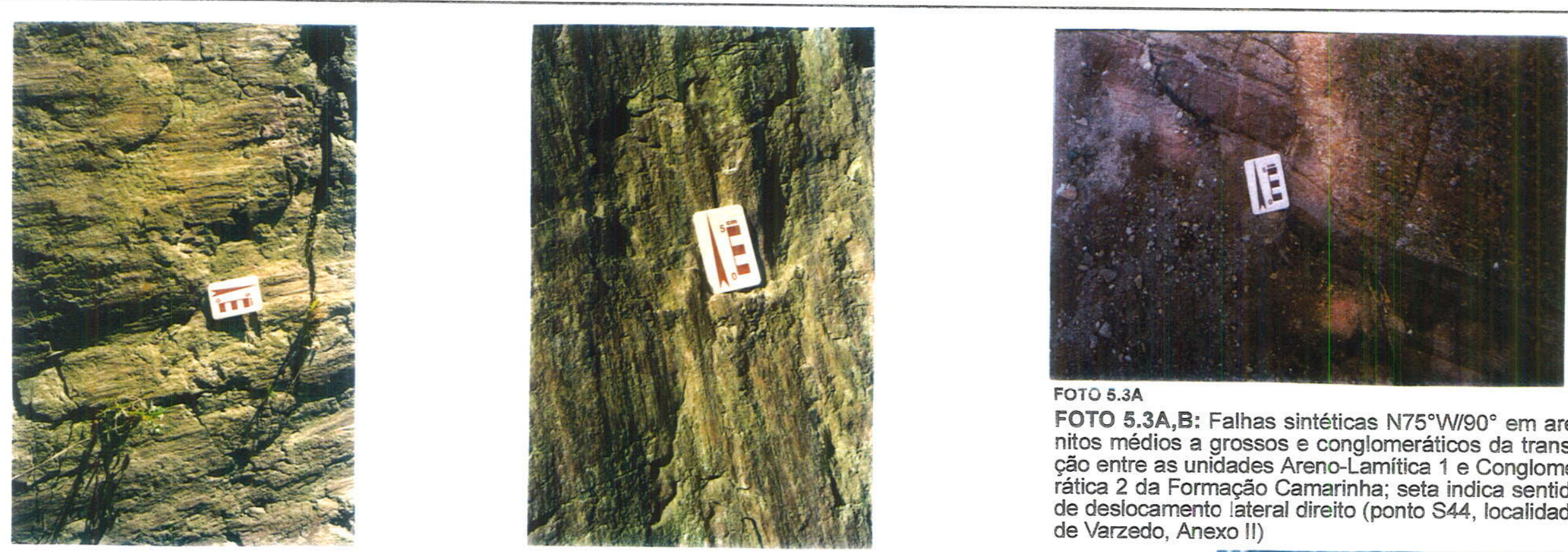

FOTO 5.3A

FOTO 5.3A,B: Falhas sintéticas $\mathrm{N} 75^{\circ} \mathrm{W} / 90^{\circ} \mathrm{em}$ arenitos médios a grossos e conglomeráticos da transição entre as unidades Areno-Lamítica 1 e Conglome rática 2 da Formação Camarinha; seta indica sentido de desiocamento lateral direito (ponto \$44, localidade

FOTO 5.1: Ressaltos e estria de atrito $\mathrm{N} 55^{\circ} \mathrm{E} / 4^{\circ}$ em FOTO 5.2: Ressaltos e estria de atrito $\mathrm{N} 50^{\circ} \mathrm{W} / 55^{\circ} \mathrm{em}$ plano $\mathrm{N} 65^{\circ} \mathrm{E} / 90^{\circ} \mathrm{em}$ arenitos médios da Unidade plano $\mathrm{N} 60^{\circ} \mathrm{E} / 60 \mathrm{NW}$ em arenitos médios da Unidade Areno-Lamítica 2 da Formação Camarinha evidenci- Areno-Lamítica 2 da Formação Camarinha evidenciando movimento Lateral Direito; seta indica sentido ando movimento Normal; seta indica sentido de movimento do bloco fotografado (ponto S103, lo- de movimento do bloco fotografado (ponto $\$ 103$, localidade de Boqueirão, Anexo II) calidade de Boqueirão, Anexo II)
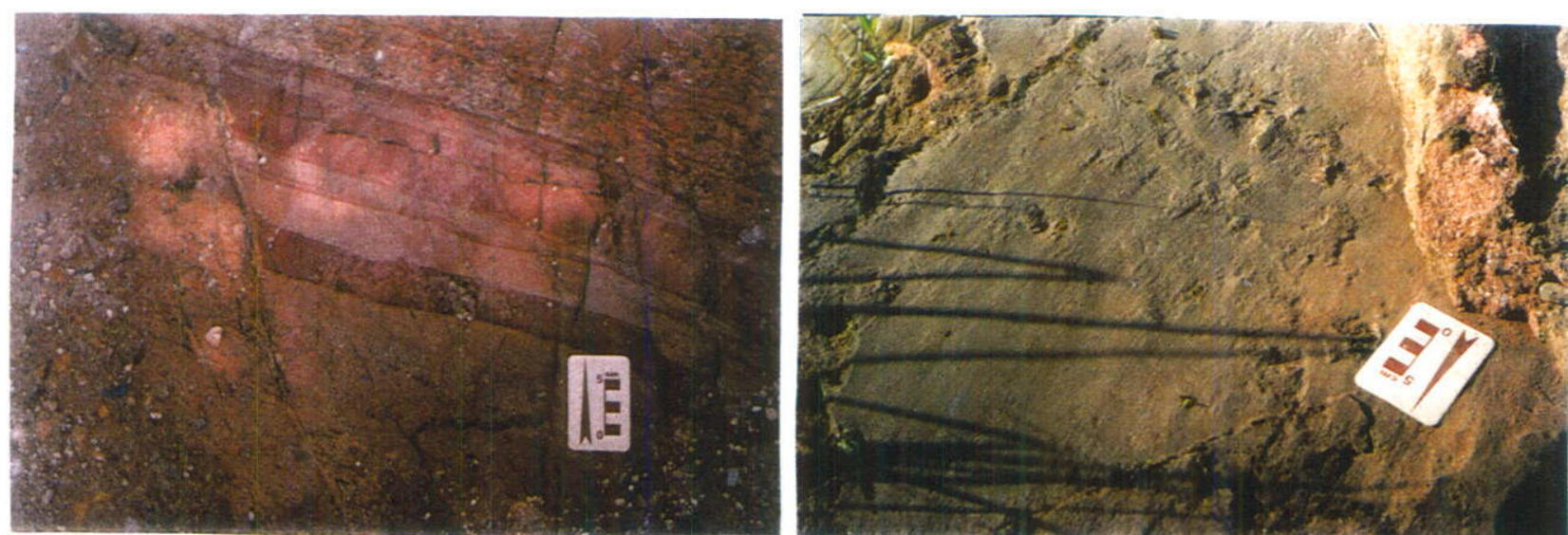

de Varzedo, Anexo II)

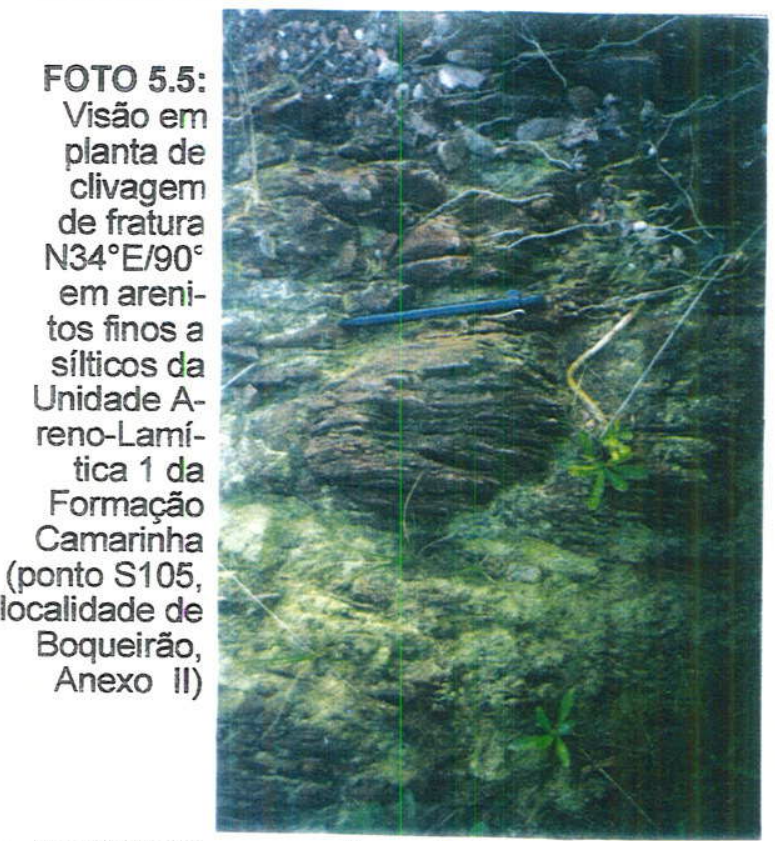

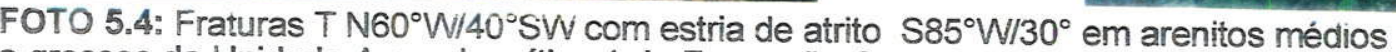
a grossos da Unidade Areno-Lamítica 1 da Formação Camarinha; seta indica sentido de deslocamento do bloco superior (ponto S11, localidade de Taquaral. Anexo II) 
responsáveis pela relativa dispersão nessas medidas relacionadas às falhas sintéticas, antitéticas e fraturas $\mathrm{T}$.

Algumas dessas estruturas geram foliação cataclástica correspondente, evidenciada por brechação, estiramento e orientação de clastos em brechas da Unidade Conglomerática 2. No estereograma da Fig.5.8, podem ser observadas concentrações máximas de medidas dessa foliação em torno de $\mathrm{N} 56^{\circ} \mathrm{E} /$ subvertical $(9,33 \%$ ), relacionada à zona de cisalhamento principal (Falha da Lancinha); $\mathrm{N} 86^{\circ} \mathrm{E} /$ subvertical $(1,33 \%)$ e $\mathrm{N} 76^{\circ} \mathrm{W} /$ subvertical $(2,66 \%)$, relacionadas às falhas sintéticas; e $\mathrm{N} 26^{\circ} \mathrm{E} /$ subvertical a $\mathrm{N} 40^{\circ} \mathrm{E} /$ subvertical, relacionadas à geração de uma foliação planoaxial associada ao dobramento escalonado. Dado o caráter anastomosado e as rotações existentes ao longo da zona de cisalhamento, estas foliações podem superpor-se ao longo de suas respectivas zonas de dispersão, uma vez que, conforme pôde ser observado no estereograma de fraturas da Fig.5.7, as medidas parecem formar uma zona quase contínua de dispersão desde os máximos correspondentes às falhas sintéticas até os máximos correspondentes às falhas antitéticas. Além disso, freqüentemente essas foliações cataclásticas mostram-se subparalelas a oblíquas (com ângulos variando em até $10^{\circ}$ ) à estrutura que as geraram, podendo assim, por sua vez, também apresentar uma dispersão própria.

\subsubsection{Análise da deformação de clastos}

Na Área Sul da Formação Camarinha, a análise deformacional do estiramento de clastos em brechas da Unidade Conglomerática 2 fornece dados como a direção média de estiramento dos mesmos ( $L x$ ) e o traçado do elipsóide médio de deformação. As dimensões dos eixos X (maior), e Z (menor), bem como os ângulos $\phi$ que o eixo $\mathrm{X}$ forma com uma linha de referência qualquer, foram medidos em um total de 527 clastos nas imediações da Falha da Lancinha, sendo 53 medidas efetuadas no ponto S56 (localidade de Varzedo), 60 medidas no ponto S76 (entre as localidades de Varzedo e Felpudo), 201 medidas no ponto S116 (entre as localidades de Boqueirão e Taquaral), e 213 medidas no ponto S139 (localidade de Retiro Grande) (Anexo II). Essas medições foram efetuadas ora em campo (pontos S56 e S76), ora em fotografias (ponto 116, Foto 5.6, e ponto 139, Foto 5.7).

Além das dimensões de eixos $\mathrm{X}$ e $\mathrm{Z}$, foram também efetuadas medidas de direção de eixos $\mathrm{X}$ em 49 clastos do ponto S56, 21 clastos do ponto S76, 30 clastos do ponto S116 e 74 clastos do ponto S139. A Área Norte não apresentou boas exposições nas quais pudessem ser efetuadas estes tipos de medidas.

Os estereogramas de direções de eixos X (Fig.5.9a,b) mostram trends para $\mathrm{N} 40^{\circ} \mathrm{E} / 8^{\circ}$ (ponto $\mathrm{S} 56$ ), $\mathrm{N} 60^{\circ} \mathrm{E} / 10^{\circ}$ (ponto $\mathrm{S} 76$ ), $\mathrm{N} 38^{\circ} \mathrm{E} / 20^{\circ}$ (ponto $\mathrm{S} 116$ ), e $\mathrm{N} 35^{\circ} \mathrm{E} / 10^{\circ}$ (ponto $\mathrm{S} 139$ ). Comparativamente ao traço principal da Falha da Lancinha (N50 $-70^{\circ} \mathrm{E}$ ), os eixos $\mathrm{X}$ de clastos do 


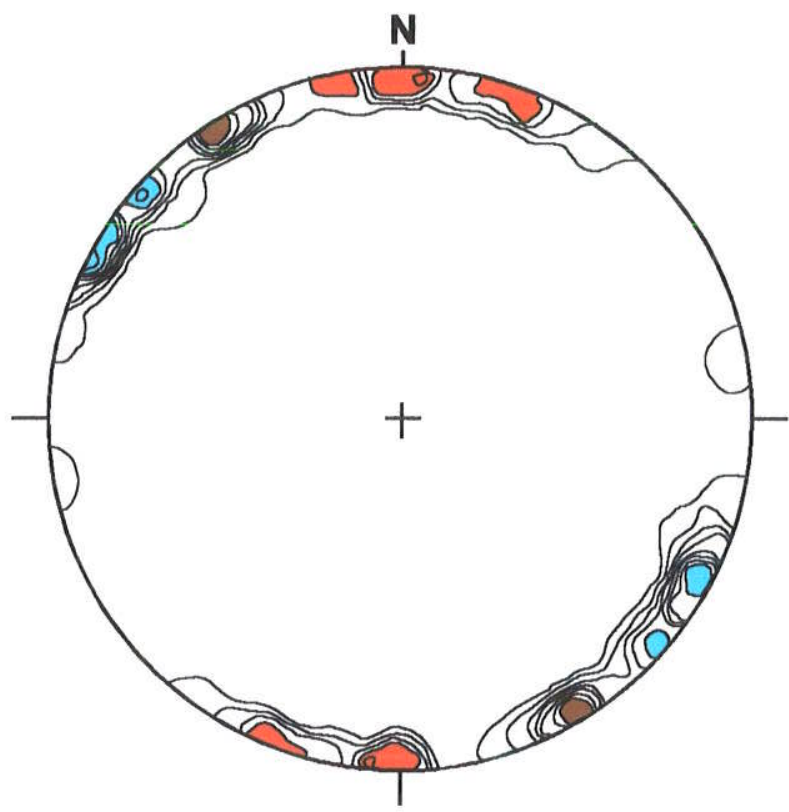

PONTOS: 75

ISOCURVAS:

$1,33 \%$

$2,67 \%$

$4,00 \%$
$5,33 \%$

$6,67 \%$

$8,00 \%$

$9,33 \%$

$10,67 \%$

MÁXIMOS:

N56 $6^{\circ} /$ subvert $(9,33 \%)$

(relacionada à zona de cisalhamento transcorrente principal da Falha da Lancinha)

$\mathrm{N} 86^{\circ} \mathrm{E} /$ subvert $(1,33 \%)$ a $\mathrm{N} 76^{\circ} \mathrm{W} /$ subvert $(2,66 \%)$

(relacionada a falhas sintéticas do sistema da Falha da Lancinha)

$\mathrm{N} 26^{\circ} \mathrm{E}$ a N $40^{\circ} \mathrm{E} /$ subvert (12\%)

(foliação plano-axial associada a dobra escalonada do sistema da Falha da Lancinha)

Fig.5.8: Estereograma de medidas de foliação cataclástica da Formação Camarinha (Area Sul), mostrando estruturas associadas à zona de cisalhamento transcorrente da Falha da Lancinha, como as desenvolvidas ao longo da zona de cisalhamento principal ( $\mathrm{N} 56^{\circ} \mathrm{E} / \mathrm{subvert}$ ) e das falhas sintéticas (N86 ${ }^{\circ} \mathrm{E} /$ subvert a $\mathrm{N} 76^{\circ} \mathrm{W} /$ subvert), e a foliação plano-axial relacionada a dobras escalonadas (N26 $\mathrm{E}$ a N40 $\mathrm{E} /$ subvert) 


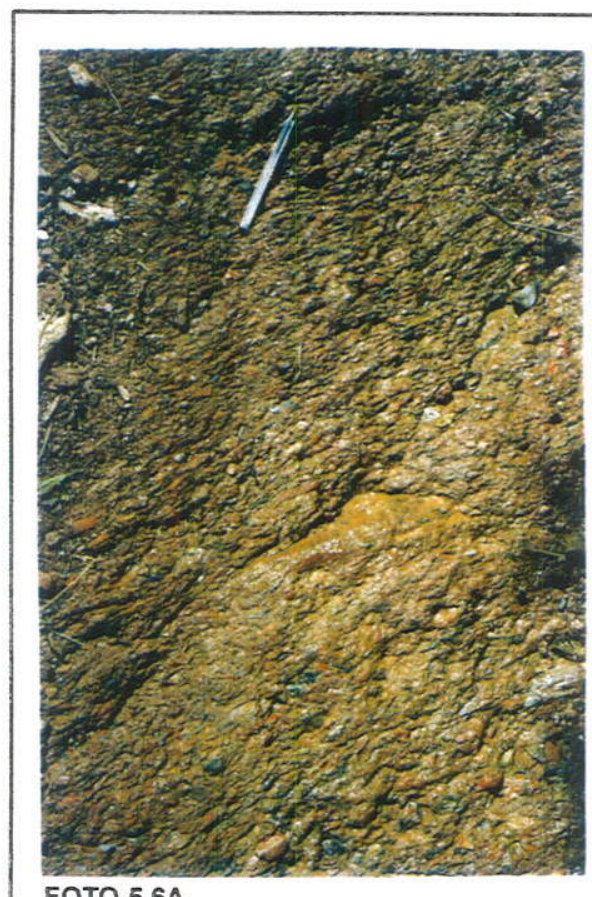

FOTO 5.6A

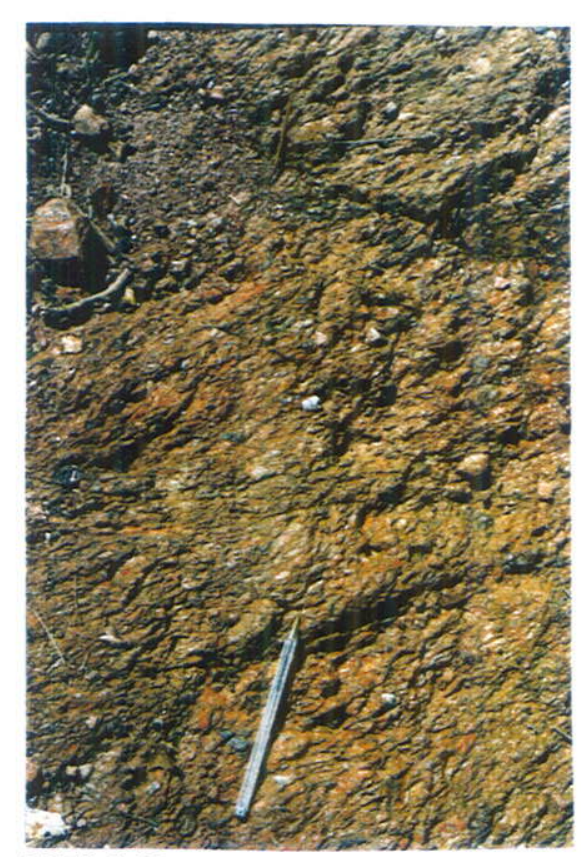

FOTO $5.6 \mathrm{~B}$

FOTO 5,6A,B : Clastos estirados em brechas da Ubidade Conglomerática 2 da Formação Camarinha; direção geral de estiramento $\mathrm{N} 38^{\circ} \mathrm{E} / 20^{\circ}$ (ponto $\mathrm{S} 116$, entre localidades de Boqueirão e Taquaral, Anexo II)

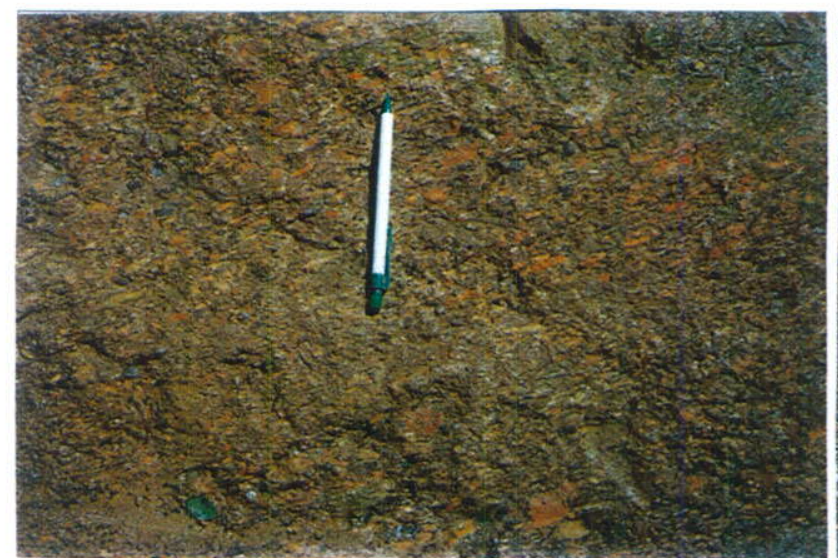

FOTO 5.7A

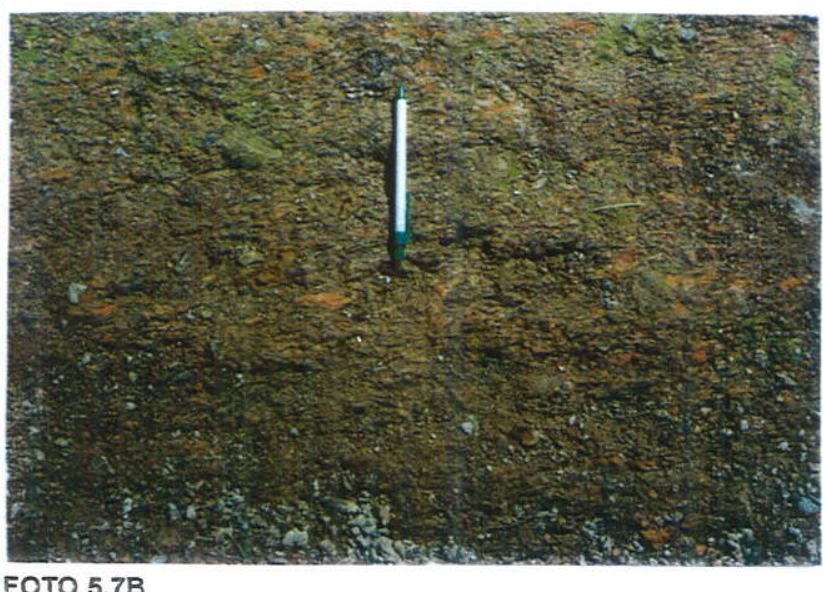

FOTO $5.7 \mathrm{~B}$
FOTO 5.7A,B: Clastos estirados em brechas da Unidade Conglomerática 2 da Formação Camarinha; direção geral de estiramento $\mathrm{N} 35^{\circ} \mathrm{E} /$ $10^{\circ}$ (ponto S1396, localidade de Onça, Anexo II) 


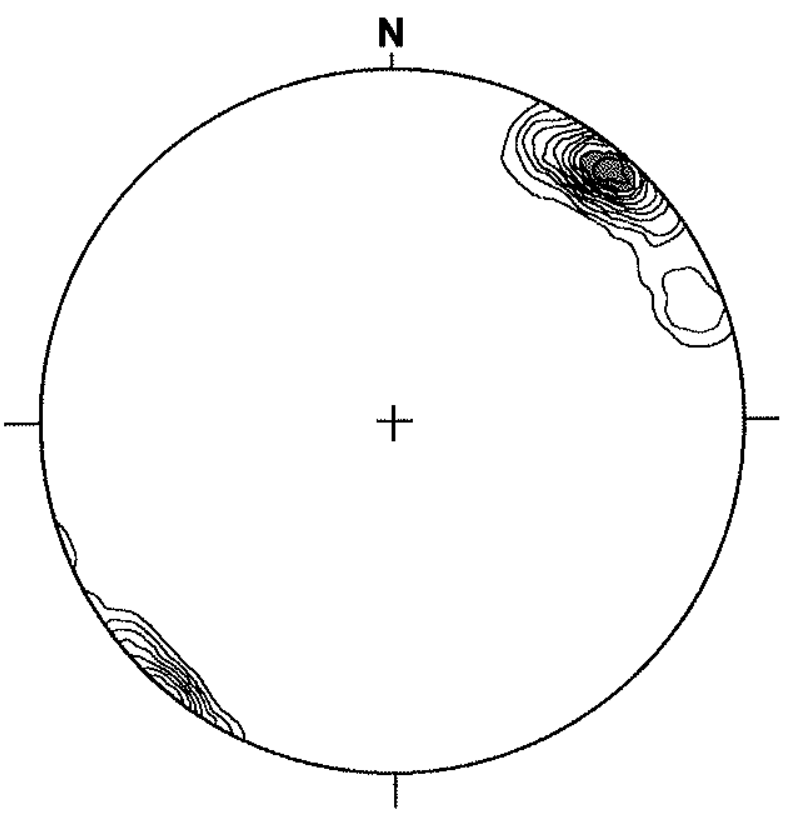

PONTOS: 49

ISOCURVAS:

$4,08 \%$

$8,16 \%$

$12,24 \%$

$16,33 \%$

$20,41 \%$

$24,49 \%$

$28,57 \%$

$32,65 \%$

$36,73 \%$

$40.8 \%$

$40,82 \%$

$44,90 \%$

MAXIMOS

(2) $\mathrm{N} 40^{\circ} \mathrm{E} / 8^{\circ}(38,77 \%)$

(direcaao principal de estiramento do eixo $X$ proxima à direção de dobramento escalonado mostrado na Fig.5.4)

(A)

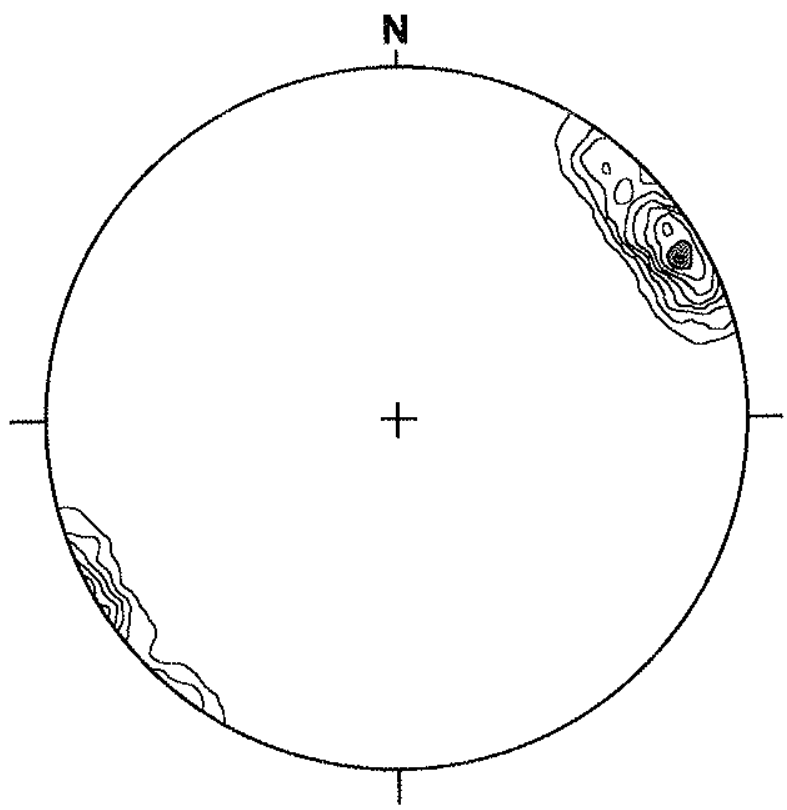

PONTOS: 21

ISOCURVAS:

$5 \%$

$10 \%$

$15 \%$

$20 \%$

$25 \%$

$35 \%$
$40 \%$
$45 \%$

$45 \%$

MÁXIMOS

- $\mathrm{N} 60^{\circ} \mathrm{E} / 10^{\circ}(38 \%)$

(direçăo principal de estiramento do eixo $X$ próxima à direção de dobramento escalonado mostrado na Fig.5.4)

(B)

Fig.5.9a: Estereogramas de clastos estirados em brechas da Unidade Conglomerática 2 da Formaçấo Camarinha, mostrando direção principal de estiramento do eixo X (LX) com caimentos sub-horizontais, nos valores de $\mathrm{N} 40^{\circ} \mathrm{E} / 8^{\circ}(\mathrm{A})$ e $\mathrm{N} 60^{\circ} \mathrm{E} / 10^{\circ}(\mathrm{B})$, próximos aos valores de eixos de dobramentos escalonados apresentados na Fig. 5.4

(A) - Ponto 556 (Varzedo, Área Sul): 49 pontos

(B) - Ponto S76 (Varzedo-Felpudo, Area Sul): 21 pontos 


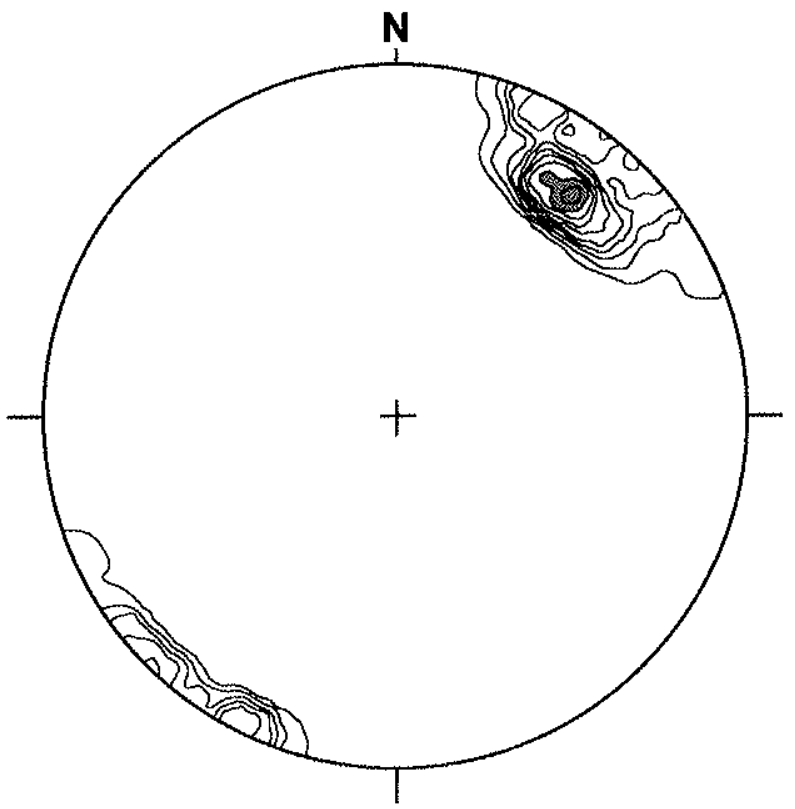

PONTOS: 30

ISOCURVAS:

$3,33 \%$

$10 \%$

$13,33 \%$

$20 \%$

$23,33 \%$

$26,67 \%$

$30 \%$

$33,33 \%$

\section{MAXIMOS}

2. $N 38^{\circ} E / 20^{\circ}(26,66 \%)$ (direçáo principal de estiramento do eixo $X$, proxima a direça de dobramento escalonado

(C)

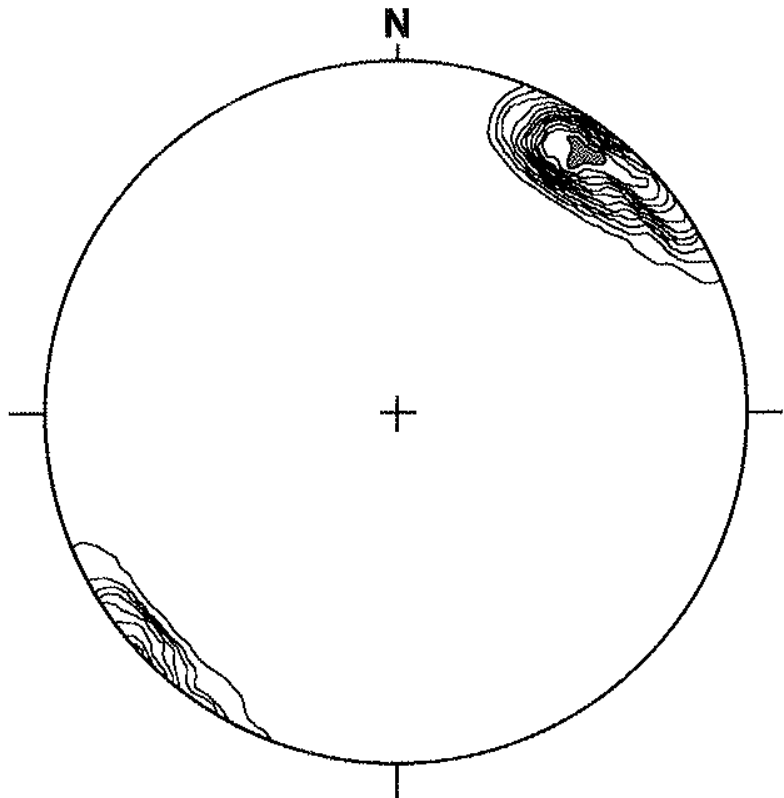

PONTOS: 74

ISOCURVAS:

$2,70 \%$

$5,41 \%$

$8,11 \%$

$10,81 \%$

$13,51 \%$

$16,22 \%$

$18,92 \%$

$21,62 \%$

$24,32 \%$

$27,03 \%$

$29,73 \%$

$32,43 \%$

MÁXIMOS

2 $\mathrm{N} 35^{\circ} \mathrm{E} / 10^{\circ}(21,62 \%)$ (direçăo principal de estiramento do eixo $X$ próxima à direçăo de dobramento escalonado mostrado na Fig.5.4)

(D)

Fig.5.9b: Estereogramas de clastos estirados em brechas da Unidade Conglomerática 2 da Formação Camarinha (cont.), mostrando direção principal de estiramento do eixo $X(\mathrm{~L} x) \mathrm{com}$ caimentos sub-horizontais, nos valores de $\mathrm{N} 38^{\circ} \mathrm{E} / 20^{\circ}(\mathrm{C})$ e $\mathrm{N} 35^{\circ} \mathrm{E} / 10^{\circ}$ (D), próximos aos valores de eixos de dobramentos escalonados apresentados na Fig.5.4

(C) - Ponto S116 (Boqueirão-Taquaral, Área Sul): 30 pontos

(D) - Ponto $\mathrm{S139}$ (Retiro Grande, Area Sul): 74: pontos 
ponto $\mathrm{S} 76$ mostraram-se paralelizados em relação à mesma, enquanto que os eixos $\mathrm{X}$ de clastos dos demais pontos mostraram-se oblíquos, com uma disposição espacial que evidencia um deslocamento lateral direito para a falha (Fig.5.10). O posicionamento do ponto $\mathrm{S} 76 \mathrm{em}$ uma região com maior concentração de ramificações anastomosadas da Falha da Lancinha pode explicar o paralelismo do eixo médio de estiramento de clastos com relação à mesma, uma vez que estruturas escalonadas tendem a paralelizar-se ao lineamento principal no decorrer do deslocamento deste, quanto mais próximas e inseridas estiverem na zona de atuação do mesmo. Os valores de caimento dos eixos $\mathrm{X}$ são bastante baixos (máximo de $20^{\circ}$ ), como é característico em zonas de cisalhamento transcorrente.

Uma vez calculadas as razões finais de estiramento dos clastos medidos $(\mathrm{Rf}=\mathrm{X} / \mathrm{Z})$, foram gerados os diagramas de isocurvas de $\mathrm{Rf}$ mostrados na Fig.5.11. Para o cálculo da Razão de Deformação $(\mathrm{Rs}=\sqrt{R f m a ́ x} \times$ Rfmín $)$, esses diagramas forneceram os seguintes valores:

\section{Ponto S56:}

Rf máx $=5,6$

Rf $\min =1,8$

$\mathrm{Rs}=\sqrt{5,6 \times 1,8}=3,17$, que coincide aproximadamente com o valor de Rf médio lido no diagrama.

\section{Ponto S76:}

Rf máx $=5,4$

Rf mín $=2,05$

Rs $=\sqrt{5,4 \times 2,05}=3,32$, que coincide aproximadamente com o valor de Rf médio lido no diagrama.

\section{Ponto S116:}

Rf máx $=8,3$

Rf min $=1,62$

$\mathrm{Rs}=\sqrt{8,3 \times 1,62}=3,75$, que coincide aproximadamente com o valor de Rf médio lido no diagrama.

\section{Ponto S139: \\ Rf máx $=7,6$ \\ Re mín $=1,75$}




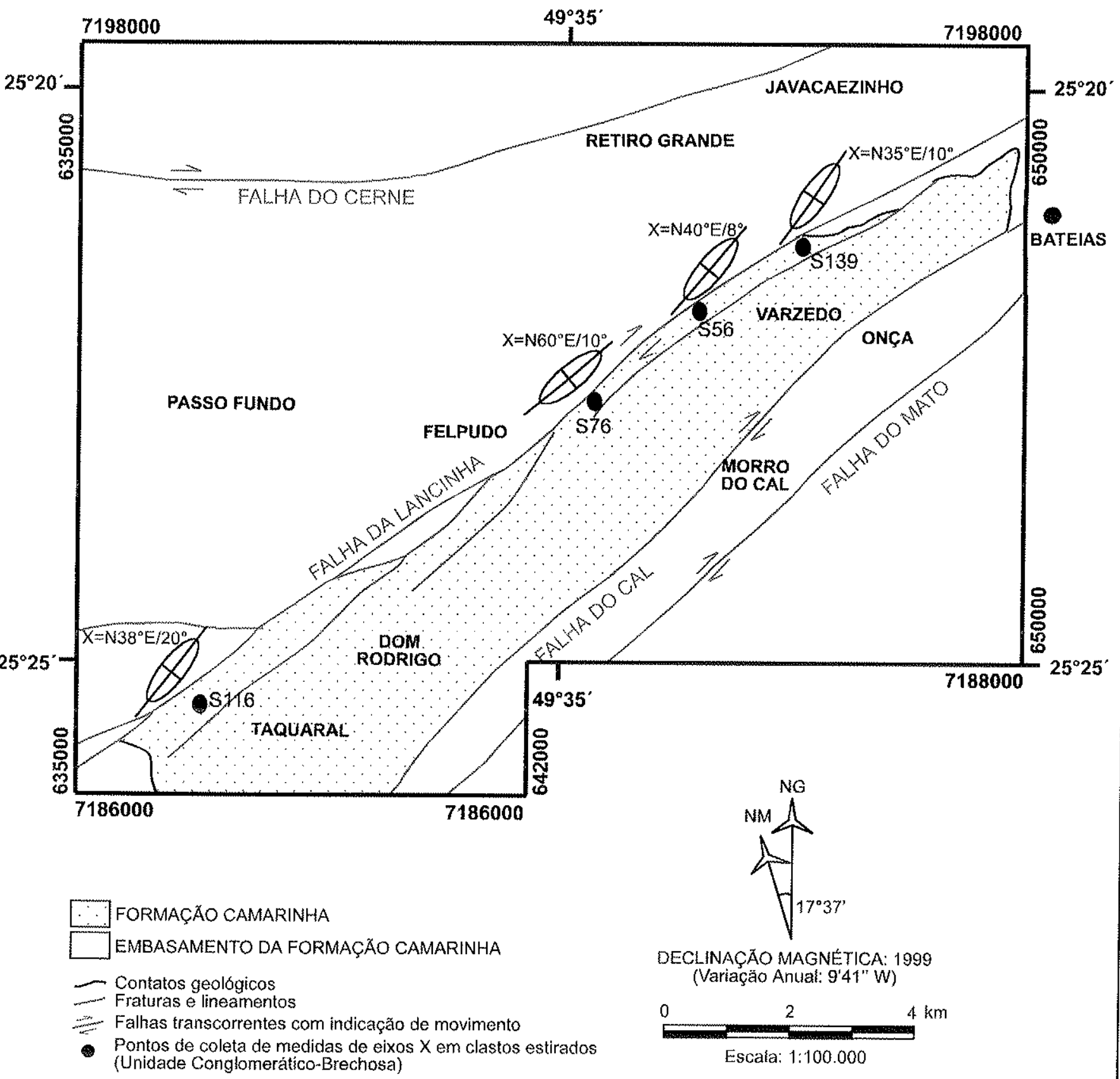

Fig.5.10: Pontos de coleta de medidas de eixos $X$ em clastos estirados da Unidade Conglomerática 2 da Formação Camarinha e orientação dos mesmos em relação à Falha da Lancinha (para maior clareza, foram omitidas as falhas de cavalgamentos, dobras, diques de diabásio e depósitos cenozóicos) 
Rs $=\sqrt{7,6 \times 1,75}=3,64$, que coincide aproximadamente com o valor de Rf médio lido no diagrama.

Com estes resultados, para o eixo menor do elipsóide de deformação igual a um valor unitário, tem-se o eixo maior do mesmo calculado proporcionalmente em:

Ponto S56: Rs $=\frac{X}{Z}$

$$
\begin{aligned}
& 3,17=\frac{X}{1} \\
& X=3,17
\end{aligned}
$$

Ponto S76: Rs $=\frac{X}{Z}$

$$
\begin{aligned}
& 3,32=\frac{X}{1} \\
& X=3,32
\end{aligned}
$$

Ponto S116: Rs $=\frac{X}{Z}$

$$
\begin{aligned}
& 3,75=\frac{X}{1} \\
& X=3,75
\end{aligned}
$$

Ponto S139: $\mathrm{Rs}=\frac{X}{Z}$

$$
\begin{aligned}
& 3,64=\frac{X}{1} \\
& X=3,64
\end{aligned}
$$

Assim, o estiramento do eixo $\mathrm{X}$ do elipsóide de deformação dos clastos é proporcionalmente de 3,1 a 3,6 vezes superior em relação ao eixo $Z$ nos quatro pontos analisados (Fig.5.11), o que revela uma deformação bastante homogênea ao longo da faixa estudada da Unidade Conglomerática 2 próxima à Falha da Lancinha, sem grandes oscilações que pudessem dever-se a variações na composição da rocha ou a pequenas variações na distância entre os pontos analisados e a zona de falha. 

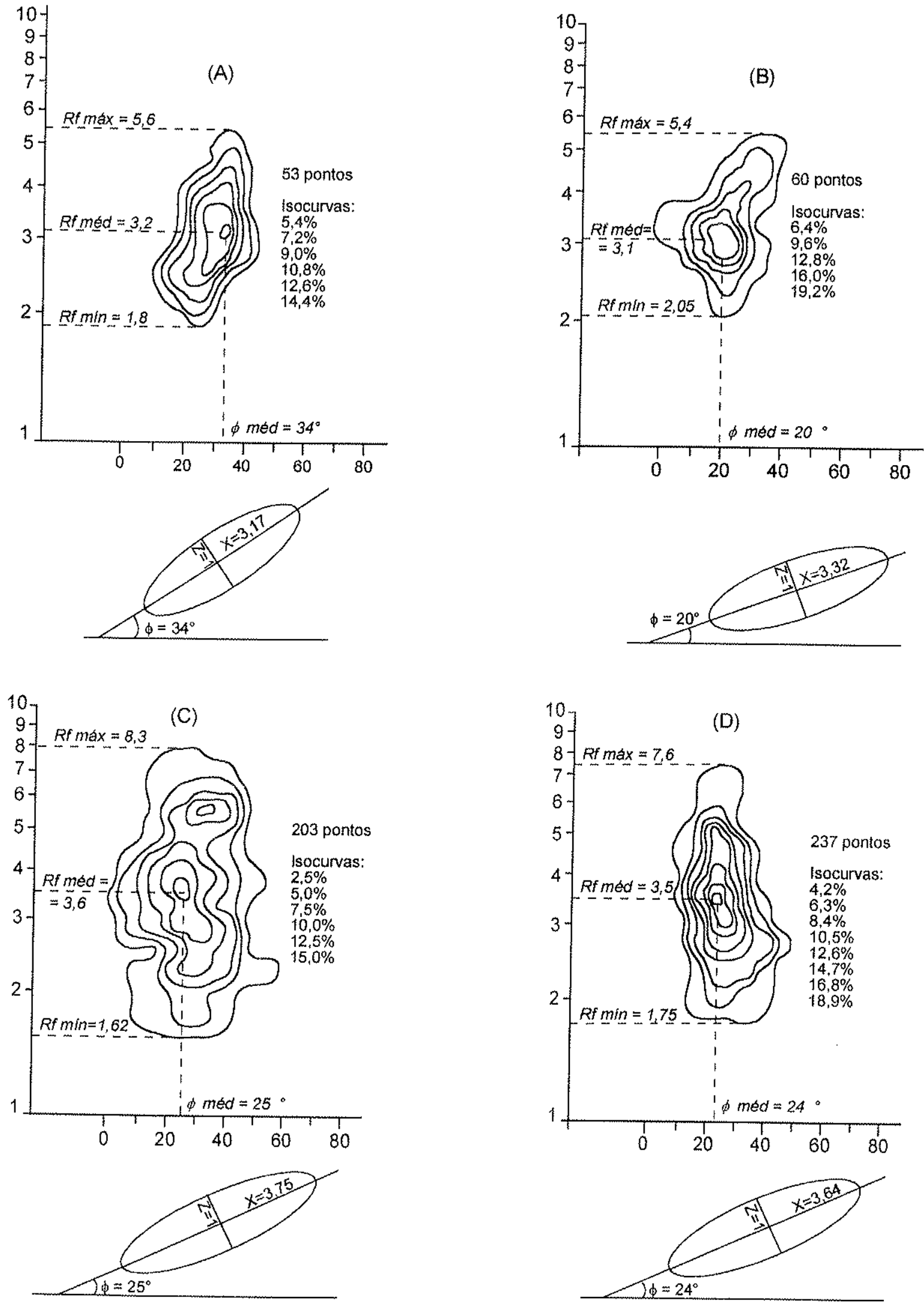

Fig.5.11: Diagramas de isocurvas de Rf em clastos da Unidade Conglomerática 2 da Formação Camarinha e elipsóides de deformação respectivos, sendo: (A) Ponto S56; (B) Ponto S76; (C) Ponto S116; (D) Ponto S139 


\section{IDADE}

\subsection{FEICÕES DA GEOCRONOLOGIA RB-SR EM ROCHA TOTAL}

A determinação da idade radiométrica de rochas sedimentares de natureza terrígena apresenta complexidades relativas ao fato de seus constituintes serem detríticos, ou seja, derivados de fontes diversas com idades variadas, refletindo assim a idade dessas fontes. Assim, a aplicabilidade dos métodos restringe-se à datação dos minerais autigênicos, isto é, formados durante a diagênese das rochas e concentrados nas frações finas (menores que $2 \mu \mathrm{m}$ ), tais como argilominerais do tipo illita, esmectita e glauconita.

Para esses minerais, os métodos $\mathrm{Rb}$-Sr e $\mathrm{K}$-Ar mostram-se os mais adequados. Entretanto, mesmo esses minerais podem estar sujeitos a alterações devido a inclusões de minerais detríticos mais antigos, soterramento e diagênese, metamorfismo, deformações tectônicas, hidrotermalismo ou intemperismo. No caso do método K-Ar, essas alterações causam, por exemplo, adição de $\mathrm{K}$ e perda de ${ }^{40} \mathrm{Ar}$ com aumento de temperatura de acordo com a profundidade de soterramento. Por esta razão, optou-se nesse trabalho pelo uso do método $\mathrm{Rb}$-Sr, embora os resultados proporcionados pelo mesmo também estejam sujeitos a interferências causadas pelos fenômenos de alteração citados, causando abertura do sistema com conseqüente re-homogeneização isotópica.

A difratometria de Raios-X, apresentada no Cap.3 (item 3.4) deste trabalho, acusou possivel presença de illita, a qual, no entanto, não pôde ser distinguida da mica fina nos difratogramas apresentados. Como tampouco foi possível analisar o índice de cristalinidade dessas illitas/micas, não se determinou se a gênese das mesmas seria detrítica, diagenética ou metamórfica.

Foi coletado um total de 17 amostras de lamitos da Unidade Areno-lamítica 1 da Formação Camarinha, visando a separação da fração menor que $2 \mu \mathrm{m}$ para análise difratométrica $\mathrm{e}$ geocronológica nos pontos S61 (6 amostras), S67 (5 amostras) e S123 (6 amostras), próximos à localidade de Felpudo, Área Sul (Anexo II). Estes pontos foram selecionados por apresentarem razoável continuidade lateral para possibilitar a coleta de amostras no mesmo nível estratigráfico em quantidades suficientes $(200 \mathrm{~g})$ para as análises efetuadas. Cada amostra foi acondicionada separadamente a fim de evitarem-se contaminações, sendo cada uma posteriormente moída e submetida à separação da fração fina por decantação no Laboratório de Geoquímica do IG-USP, no mesmo processo utilizado para a Difratometria de Raios-X.

Após a separação da fração menor que $2 \mu \mathrm{m}$ e a análise por difratometria de Raios-X, as amostras foram secas e submetidas à análise semi-quantitativa por meio de fluorescência de Raios$\mathrm{X}$ no CPGEO (Centro de Pesquisas Geocronológicas) do IG-USP, visando uma determinação preliminar dos teores de Rb e Sr presentes. Esta análise revelou que 5 das 6 amostras do ponto S61 
$(\mathrm{b}, \mathrm{c}, \mathrm{d}, \mathrm{e}, \mathrm{f}$ ), duas das 5 amostras do ponto $\mathrm{S} 67$ (b, e), e duas das 5 amostras do ponto $\mathrm{S} 123$ (d, e) apresentaram razões ${ }^{87} \mathrm{Rb} /{ }^{86} \mathrm{Sr}$ suficientemente distribuídas entre os valores máximos e mínimos. Estas amostras foram então submetidas a diluição isotópica e espectrometria.

Os resultados da diluição isotópica são apresentados na Tab.6.1, e a isócrona segundo Williamson (1968) gerada pelos dados do ponto $\$ 61$ pode ser visualizada na Fig.6.1. Os resultados indicam uma idade de $432.8 \pm 6.3 \mathrm{Ma}$, tratando-se no entanto de uma "errócrona", devido ao elevado valor de MSWD (23.50).

\begin{tabular}{|c|c|c|c|c|c|c|}
\hline PONTO & $\mathbf{R b}(\mathbf{p p m})$ & $\mathbf{S r}(\mathbf{p p m})$ & $\mathbf{R b}^{87} / \mathbf{S r}^{86}$ & Erro & $\mathbf{S r}^{87} / \mathbf{S r}^{86}$ & Erro \\
\hline S61-b & 254.92 & 34.35 & 21.8271 & 0.1750 & 0.87227 & 0.00041 \\
\hline S61-c & 287.90 & 71.75 & 11.7345 & 0.0942 & 0.81787 & 0.00002 \\
\hline S61-d & 288.55 & 69.88 & 12.0814 & 0.0975 & 0.81956 & 0.00008 \\
\hline S61-e & 290.01 & 72.60 & 11.6848 & 0.0940 & 0.81710 & 0.00007 \\
\hline S61-f & 272.84 & 36.58 & 21.9660 & 0.1781 & 0.88692 & 0.00046 \\
\hline S67-b & 148.63 & 78.24 & 5.5373 & 0.0441 & 0.78062 & 0.00004 \\
\hline S67-e & 202.56 & 86.55 & 6.8252 & 0.0548 & 0.78587 & 0.00003 \\
\hline S123-d & 251.34 & 32.20 & 22.9976 & 0.1856 & 0.89164 & 0.00007 \\
\hline S123-e & 253.56 & 33.37 & 22.3776 & 0.1805 & 0.88631 & 0.00013 \\
\hline
\end{tabular}

Tab.6.1: Dados resultantes da diluição isotópica efetuada para datação geocronológica $\mathrm{Rb}-\mathrm{Sr}$ em lamitos da Unidade Areno-Lamítica 1 da Formação Camarinha

Os valores de MSWD e do erro podem ser minorados acrescentando-se à "errócrona" gerada as amostras correspondentes aos pontos S67 e S123, produzindo-se uma nova "errócrona" apresentada na Fig.6.2., com valores de idade igual a $437.7 \pm 2.5 \mathrm{Ma}$ e de MSWD igual a 18.17. Embora as quatro amostras acrescentadas não pertençam ao mesmo afloramento das amostras do ponto S61, encontram-se bastante próximas geograficamente, e pertencem à mesma unidade da Formação Camarinha. Tal procedimento foi considerado viável, por observar-se que pouco afeta o resultado final da idade, tendo-se pretendido datar a Unidade Areno-Lamítica 1 da Formação Camarinha em caráter geral, e não um nível estratigráfico específico da mesma.

O Quadro 6.1 mostra uma compilação de idades obtidas por métodos diversos (Rb-Sr, K-Ar, $\mathrm{U}-\mathrm{Pb}$ e análise paleontológica) para rochas sedimentares e vulcânicas de algumas das bacias eopaleozóicas do sul e sudeste do Brasil, todas variando entre 630 e $490 \mathrm{Ma}$, pertencendo, portanto, 


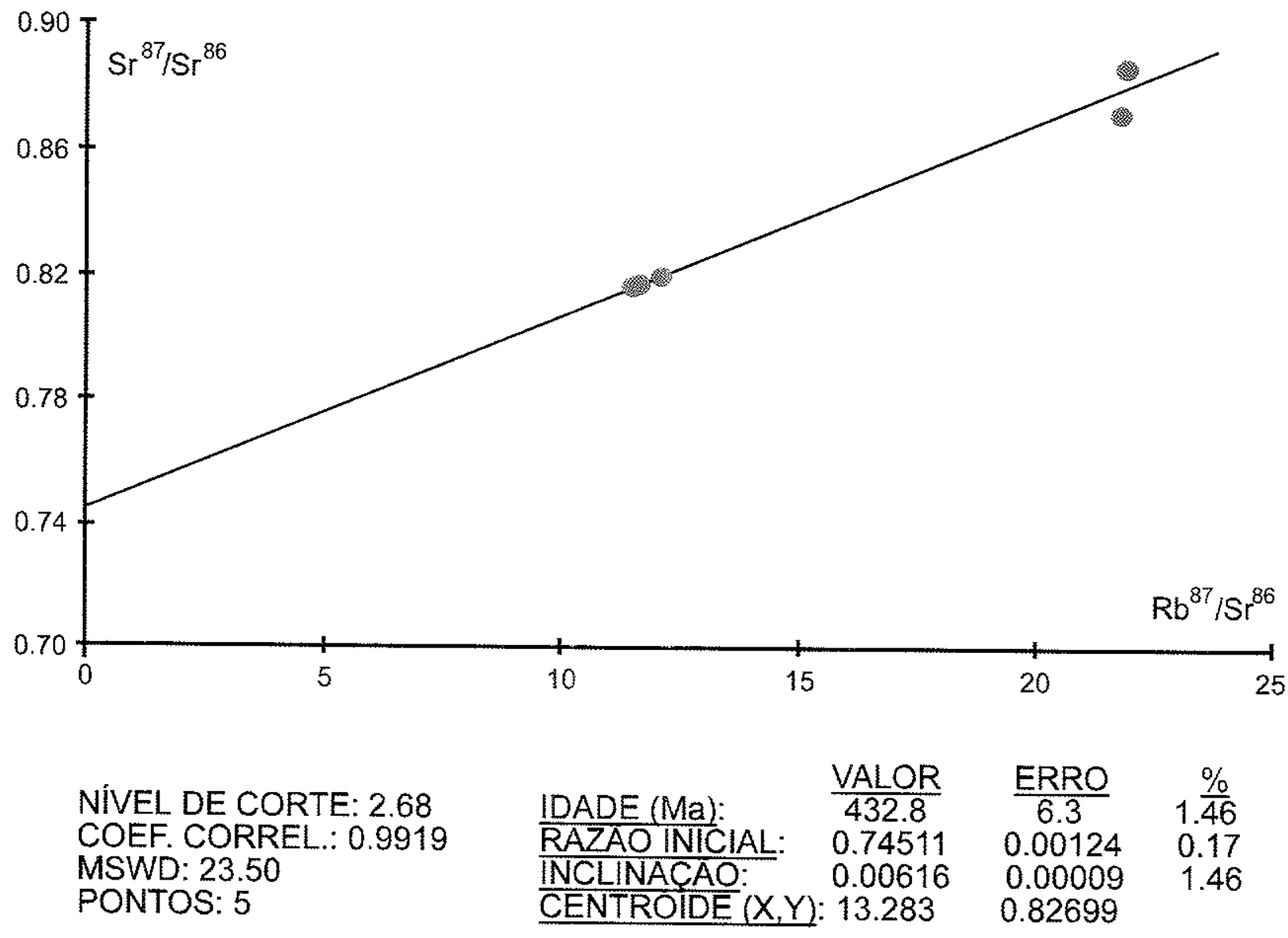

Fig.6.1: Isócrona tipo Williamson das amostras de fração fina de lamitos do ponto S61 (Unidade Areno-Lamítica 1) da Formação Camarinha, para idade $\mathrm{Rb}-\mathrm{Sr}$ de $432.8 \pm 6.3 \mathrm{Ma}$ e MSWD $=23.50$ 


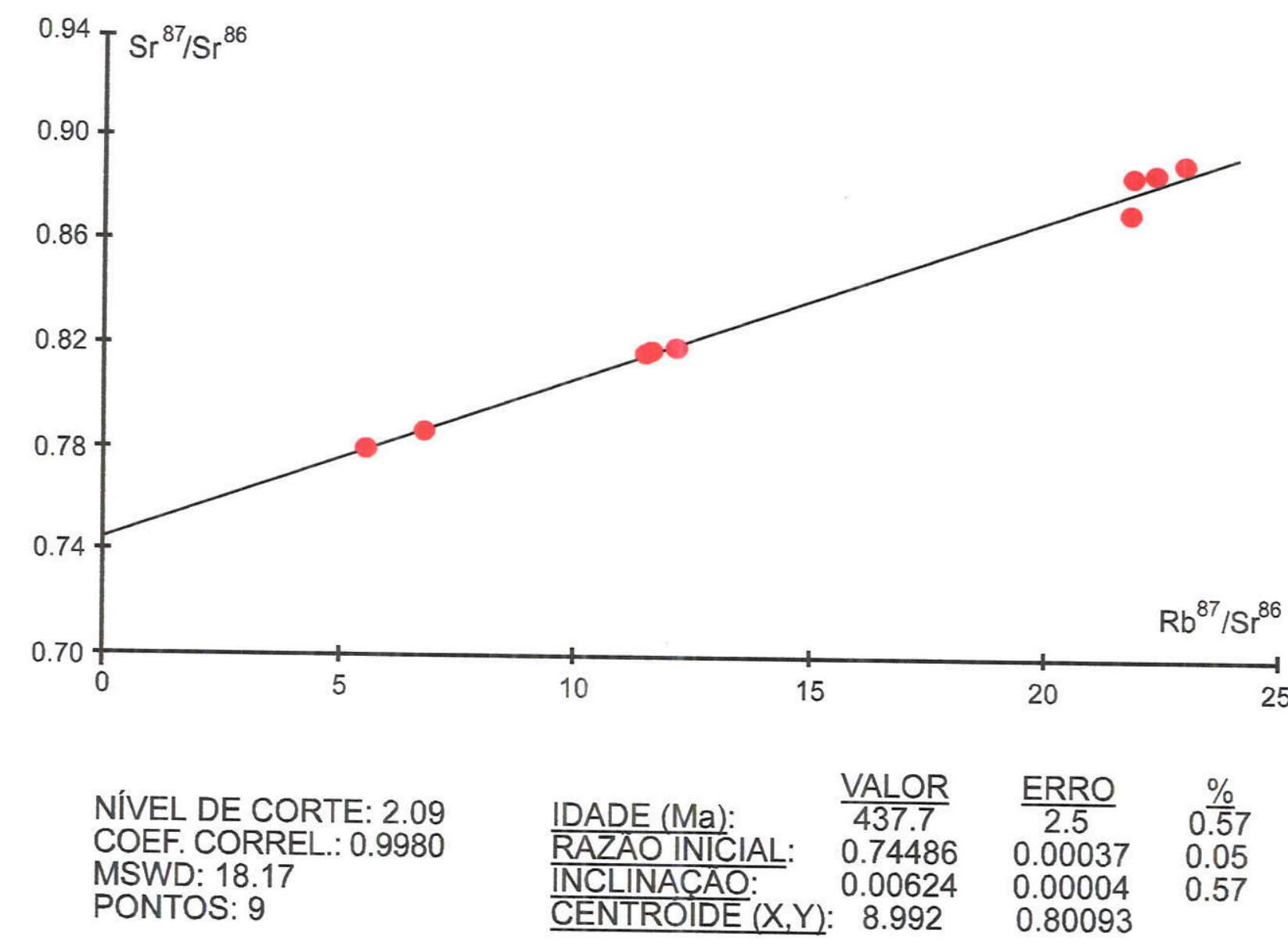

Fig.6.2: Isócrona tipo Williamson das amostras de fração fina de lamitos dos pontos S61, S67 e S123 (Unidade ArenoLamítica 1) da Formação Camarinha, para idade Rb-Sr de 437.7 \pm 2.5 Ma e MSWD $=18.17$ 


\begin{tabular}{|c|c|c|c|c|}
\hline $\begin{array}{c}\text { BACIA OU } \\
\text { FORMAC } \tilde{O} O \\
\end{array}$ & AUTOR(ES) & $\begin{array}{l}\text { MATERIAL } \\
\text { ANALISADO } \\
\end{array}$ & METODODO & $\begin{array}{c}\text { DADE (Ma) E } \\
\text { INTERPRETACÕES } \\
\end{array}$ \\
\hline Pouso Alegre & Hama \& Cunha (1977) & Biotitas e sericitas finas & $\mathrm{K}-\mathrm{Ar}$ & $\begin{array}{c}485 \pm 20 \text { (biotitas) } \\
524 \pm 20 \text { (sericitas) } \\
\text { (metamorfismo de baixo grau) }\end{array}$ \\
\hline \multirow[t]{2}{*}{ Castro } & Moro (1993) & Riolitos & $\mathrm{Rb}-\mathrm{Sr}$ & $\begin{array}{l}488.4 \pm 7.9 \text { (R.I. } 0.71375) \\
466.6 \pm 7.7 \text { (R.I. } 0.70981)\end{array}$ \\
\hline & $\begin{array}{c}\text { Cordani et al. } \\
(1999)\end{array}$ & Riolitos (?) & $\begin{array}{c}\text { U-Pb } \\
\text { SHRIMP }\end{array}$ & $543 \pm 12$ \\
\hline \multirow[b]{2}{*}{ Camarinha } & $\begin{array}{l}\text { Basei et al. } \\
\text { (1998) }\end{array}$ & Fraçấo fina de sedimentos & $\mathrm{K} n \mathrm{Ar}$ & $\begin{array}{l}505 \pm 10 \text { e } 478 \pm 10 \\
\text { (anquimetamorfismo) }\end{array}$ \\
\hline & Ciguel et al. (1992) & $\begin{array}{c}\text { Gordia arcuata } \\
\text { Ksiazkiewicz, Planolites } \\
\text { montamus Richter, } \\
\text { Skolithos Haldemann e } \\
\text { cubicnia } \\
\end{array}$ & - & Vendiano-Tommotiano \\
\hline \multirow{3}{*}{ Guaratubinha } & Siga Jr. et al. & \multirow{2}{*}{ Riolitos } & $\mathrm{Rb}-\mathrm{Sr}$ & $570 \pm 10$ (R.I. 0.70947$)$ \\
\hline & & & $\mathrm{U}-\mathrm{Pb}$ & $628 \pm 28$ \\
\hline & $\begin{array}{l}\text { Basei et al. } \\
\text { (1998) }\end{array}$ & Riolitos & $\mathrm{U}-\mathrm{Pb}$ & $604.6 \pm 8.6$ \\
\hline \multirow{5}{*}{ Campo Alegre } & Citroni (1998) & \multirow{2}{*}{ Riolitos } & $\mathrm{Rb}-\mathrm{Sr}$ & $570 \pm 39$ (R.I. 0.70690$)$ \\
\hline & Citroni et al. (1999) & & $\mathrm{U}-\mathrm{Pb}$ & $579 \pm 30$ \\
\hline & Siga Jr. et al. (1999) & Riolitos & $\mathrm{U}-\mathrm{Pb}$ & $528 \pm 29$ \\
\hline & $\begin{array}{l}\text { Cordani et al. } \\
(1999) \\
\end{array}$ & Riolitos & $\begin{array}{c}\text { U Pb } \\
\text { SHRIMP } \\
\end{array}$ & $595 \pm 16$ \\
\hline & $\begin{array}{c}\text { Basei et al. } \\
(1998)\end{array}$ & Riolitos & $\mathrm{U}-\mathrm{Pb}$ & $598 \pm 29$ \\
\hline \multirow{8}{*}{ Itajaí } & Paim et al. (1997) & Chancelloria sp. & - & 540 (estimada) \\
\hline & Macedo et al. (1984) & $\begin{array}{l}\text { Fração fina e rocha total } \\
\text { em sedimentos }\end{array}$ & $\mathrm{Rb}-\mathrm{Sr}$ & $\begin{array}{l}530 \pm 20 \text { (R.I. } 0.718 \text { ) } \\
542 \pm 18 \text { (R.I. } 0.718 \text { ) }\end{array}$ \\
\hline & \multirow{4}{*}{ Basei et al. (1987) } & \multirow[t]{2}{*}{$\begin{array}{c}\text { Recalculado de Macedo et } \\
\text { al. }(1984)\end{array}$} & $\mathrm{Rb}-\mathrm{Sr}$ & $\begin{array}{c}581 \pm 48 \text { (sedimentação e } \\
\text { diagênese); } 535 \pm 10 \\
\text { (anquimetamorfismo) }\end{array}$ \\
\hline & & & $\mathrm{K}-\mathrm{Ar}$ & $525 \pm ?$ \\
\hline & & Tufos & $\mathrm{Rb}-\mathrm{Sr}$ & $534 \pm 4$ \\
\hline & & Riolito Apiúna & $\mathrm{Rb}-\mathrm{Sr}$ & $544 \pm 20$ (R.I. 0.705$)$ \\
\hline & Basei et al. (1999) & Riolito Apiúna & $\mathrm{U}-\mathrm{Pb}$ & $567 \pm 14$ \\
\hline & $\begin{array}{c}\text { Cordani et al. } \\
(1999)\end{array}$ & Riolito Apiúna & $\begin{array}{c}\text { U-Pb } \\
\text { SHRIMP }\end{array}$ & $563 \pm 14$ \\
\hline $\begin{array}{l}\text { Camaquã - Santa } \\
\text { Bárbara }\end{array}$ & Netto et al. (1992) & $\begin{array}{c}\text { Cochlicus, } \\
\text { Didymaulichnus, } \\
\text { Diplocraterion (?), } \\
\text { Gyrolithes, Intrites, } \\
\text { Planolites, Rusophycus, } \\
\text { Skolithos(?), Cruziana(?) } \\
\end{array}$ & - & Vendiano - Tommotiano \\
\hline Camaquã & $\begin{array}{c}\text { Bonhomme \& Ribeiro } \\
\text { (1983) }\end{array}$ & Fração fina de sedimentos & $\mathrm{K}-\mathrm{Ar}$ & $\begin{array}{c}572 \pm 17 \text { e } 535 \pm 16 \\
\text { (anquimetamorfismo) }\end{array}$ \\
\hline Guaritas (?) & $\begin{array}{c}\text { Bonhomme \& Ribeiro } \\
(1983) \\
\text { Fambrini }(1998)\end{array}$ & Fração fina de sedimentos & $\mathrm{K}-\mathrm{Ar}$ & $\begin{array}{c}529 \pm 16 \text { e } 524 \pm 16 \\
\text { (diagênese) }\end{array}$ \\
\hline$\frac{\text { Camaquã (topo) }}{\text { Camaquã (?) }}$ & Fambrini (1998) & \multirow{3}{*}{ Riolitos e ignimbritos } & \multirow{3}{*}{$\mathrm{Rb}-\mathrm{Sr}$} & $545.1 \pm 12.7$ (R.I. 0.7093 ) \\
\hline$\frac{\text { Camaqua (?) }}{\text { Grupo Crespos }}$ & $\frac{\text { Almeida et al. (1996) }}{\text { Fambrini (1998) }}$ & & & $\begin{array}{c}546 \pm 12.9 \text { (R.1. } 0.7067) \\
494.9+15(R I 07145)\end{array}$ \\
\hline & & & & $494.9 \pm 15.1$ (R.I. 0.7145$)$ \\
\hline
\end{tabular}

Quadro 6.1: Idades de formação ou alterações de rochas sedimentares e vulcânicas de parte das bacias da transição Neoproterozóico-Cambriano/Ordoviciano do Sul e Sudeste do Brasil, baseadas em datações radiométricas diversas e análise de conteúdo fossilífero 
à transição Neoproterozóico-Cambriano/Ordoviciano. No caso da Formação Camarinha, as duas "errócronas" obtidas neste trabalho indicam idades correspondentes ao Ordoviciano, portanto bastante mais jovens que as supostas para a formação, também considerada como pertencente à transição Neoproterozóico-Eopaleozóico devido a suas características litoestratigráficas e estruturais. As razões iniciais ${ }^{87} \mathrm{Sr} /{ }^{86} \mathrm{Sr}$ obtidas neste trabalho (em torno de 0.745 ) mostram-se mais elevadas do que as obtidas pelo mesmo método quando utilizado para datações em outras bacias do sul e sudeste do Brasil (em torno de 0.71). Estas razões iniciais assim elevadas são sugestivas de uma forte re-homogeneização isotópica.

Re-homogeneizações isotópicas são apontadas em modelos desenvolvidos por Thomaz Filho (1976) como responsáveis por elevações nas razões iniciais e rejuvenescimentos de idades $\mathrm{Rb}$-Sr em rochas sedimentares. Considerando-se que a bacia da Formação Camarinha sofreu considerável deformação por tectônica transcorrente, e que suas rochas encontram-se bastante alteradas hidrotermal e intempericamente, depreende-se que eventos posteriores à sua sedimentação e diagênese devem ter sido os responsáveis pela re-homogeneização isotópica observada, afetando as razões iniciais ${ }^{87} \mathrm{Sr} /{ }^{86} \mathrm{Sr}$ e alterando, portanto, os resultados de idades esperados. Tais eventos devem estar provavelmente relacionados a reativações tensionais paleozóicas do sistema da Falha da Lancinha. A alteração hidrotermal sericítica observada na análise petrográfíca (Cap.3, item 3.3 deste trabalho) pode estar relacionada tanto ao evento deformacional principal (lateral direito) que atuou sobre a bacia da Formação Camarinha, como a qualquer dos demais eventos aqui citados, podendo ou não ser a responsável direta pelos resultados geocronológicos obtidos. As idades $\mathrm{K}-\mathrm{Ar}$ de $505 \pm 10$ e $478 \pm 10$ obtidas por Basei et al. (1998) são interpretadas pelos autores como resultantes de um anquimetamorfismo, o que faz supor que a deposição propriamente dita dos sedimentos tenha ocorrido antes desse período.

Desta forma, enquanto novos e melhores dados geocronológicos e paleontológicos não forem obtidos, estimativas de idade para a Formação Camarinha podem ser feitas com base em suas relações com seu embasamento (de idade U-Pb próxima a 615-619 Ma segundo Hackspacher et al., 1999) e com bacias similares já datadas. Destas bacias, a de Castro apresenta idades U-Pb de $543 \pm$ $12 \mathrm{Ma}$ para o vulcanismo riolítico que a caracteriza (Cordani et al., 1999, Quadro 6.1) e não se encontra deformada pela tectônica transcorrente que afetou a bacia da Formação Camarinha, o que pode indicar uma idade para a bacia de Castro mais jovem do que a da Formação Camarinha. Com base nisto e no conteúdo icnofossilifero detectado por Ciguel et al. (1992, Quadro 6.1), são esperáveis idades entre 540 e 600 para a Formação Camarinha, à semelhança das outras bacias similares do Sul e Sudeste do Brasil (Quadro 6.1). Qualquer correlação a ser feita entre a Bacia da Formação Camarinha e estas demais bacias deverá levar em conta critérios litoestratigráficos, estruturais e paleontológicos. Estas correlações serão discutidas no Cap.7 do presente trabalho. 


\section{DISCUSSÃO DOS RESULTADOS}

Neste capítulo, serão feitas algumas considerações sobre os resultados obtidos ao longo deste trabalho, suas interpretações e implicações, principalmente com relação aos estudos já efetuados e aos modelos propostos anteriormente, procurando-se justificar as interpretações aqui realizadas com base nas feições observadas na área em estudo e na literatura consultada. Os assuntos abordados seguem os objetivos propostos no Cap.1, item 1.1 do presente trabalho.

\subsection{ATUALIZAÇÃO DO MAPA GEOLÓGICO}

Os trabalhos de fotointerpretação e mapeamento da bacia da Formação Camarinha revelaram uma distribuição espacial e empilhamento estratigráfico bastante diversos daqueles mapeados e propostos anteriormente. Ao invés de uma seqüência predominantemente síltica com intercalações conglomeráticas e arenosas, como proposto por Muratori et al. (1967) e mantido pelos autores que se seguiram, verificou-se a ocorrência de quatro unidades distintas com contatos transicionais entre si, sendo uma conglomerático-arenosa na base (Unidade Conglomerática 1), seguida de uma unidade arenosa e pelítica (Unidade Areno-Lamítica 1), outra unidade conglomerático-arenosa (Unidade Conglomerática 2) e uma última unidade arenosa e pelítica (Unidade Areno-Lamítica 2).

A Unidade Conglomerática 1 tem poucos metros de espessura aflorante, ocorrendo apenas na Área Sul, em pontos locais próximos ao limite sudeste da mesma nas localidades de Boqueirão e Felpudo, e em um ponto adjacente a seu limite noroeste, na localidade de Felpudo. O contato desta unidade com o embasamento da Formação Camarinha, quando exposto, mostra discordância angular e brechação por falhas. A Unidade Areno-Lamítica 1 aflora na Área Sul em uma faixa de direção NE-SW adjacente ao limite sudeste da mesma (localidades de Boqueirão, Dom Rodrigo, Felpudo, Varzedo e Onça), e em uma lente junto ao limite noroeste da mesma área na localidade de Felpudo. Ocorre ainda em uma pequena lente de direção EW entre as localidades de Taquaral e Camarinha. $\mathrm{Na}$ Área Norte, aflora como uma faixa dobrada na forma de um sinclinal com fechamento para nordeste, entre as localidades de Rio dos Matos, Santa Cruz e Itambezinho.

A Unidade Conglomerática 2 aflora ao longo de toda a extensão da Área Sul, entre as localidade de Purunã e Bateias, e também como uma faixa dobrada na forma de um sinclinal com fechamento para nordeste na Área Norte, entre as localidades de Prata, Santa Cruz e Itambezinho. Finalmente, a Unidade Areno-Lamítica 2 ocorre na Área Sul na forma de pequenas lentes intercaladas à Unidade Conglomerática 2 nas localidades de Taquaral, Varzedo e Onça, enquanto na 
Área Norte ocorre em uma faixa mais larga, também dobrada na forma de um sinclinal com fechamento para nordeste nas regiões de parte do Rio Açungui, Rio da Prata e Arroio Santana.

\subsection{PREENCHIMENTO SEDIMENTAR}

O contato entre as unidades constituintes da Formação Camarinha é transicional, ocorrendo na forma de gradações e interdigitações. É verificada, assim, uma sucessão constituída por seqüências retrogradantes e progradantes de sedimentos característicos de leques do tipo fandelta, com porções subaéreas constituídas predominantemente por depósitos de fluxos de detritos e sheetfloods, e porções subaquosas constituídas por depósitos em ambiente de frente deltaica na forma de fluxos de detritos, areias e lamas, correntes de turbidez e depósitos de barras de desembocadura proximais e distais. A Unidade Conglomerática 1 corresponderia aos depósitos de fluxos gravitacionais presentes na porção mais proximal da frente deltaica; a Unidade Areno-Lamítica 1 corresponderia também a depósitos de fluxos gravitacionais, porém mais distais que os primeiros, além de correntes de turbidez de alta a baixa densidade e depósitos de barra de desembocadura proximais e distais, apresentando retrabalhamentos por ondas; a transição da Unidade ArenoLamítica 1 para a Unidade Conglomerática 2 e esta última corresponderiam aos depósitos subaquosos a subaéreos de sheet-floods e fluxos de detritos de um leque progradante sobre os depósitos anteriores; e a Unidade Areno-Lamítica 2 corresponderia aos novos depósitos de barras de desembocadura proximais e distais deste novo leque progradante, também com retrabalhamentos por ondas.

Esta sucessão indica que as fácies subaéreas mais proximais do início da deposição dos sedimentos da Formação Camarinha (que deveriam ser representadas por depósitos de fluxos de detritos e sheet-floods da porção subaérea dos leques imediatamente adjacentes à área-fonte) não se encontram preservadas, uma vez que os pacotes mais proximais da Formação Camarinha atualmente aflorante (Unidade Conglomerática 1) consistem em depósitos já das porções subaquosas dos leques. A ciclicidade das sucessões, que ocorrem na forma de progradações e retrogradações, aliada à abundância de depósitos gravitacionais e à freqüência de estruturas de sobrecarga podem ser indicativos de atuação de uma tectônica sin-sedimentar na área-fonte.

A coexistência de depósitos gravitacionais e correntes de turbidez com depósitos de frente deltaica, em regiões de águas ainda pouco profundas e sujeitas à ação de ondas (como observado na Formação Camarinha), pode ocorrer mesmo a gradientes mais baixos (até $1^{\circ}$ segundo Kersey e Hsü, 1976, ou 1, $5^{\circ}$ segundo Prior e Bornhold, 1990) se o aporte de carga sedimentar for suficientemente elevado, causado por sismicidade ou eventos catastróficos de enchentes na área-fonte e transportado pelos canais distributários do sistema (McPherson et al., 1987, 1988; Massari e Colella, 1988; 
Marzo e Anadón, 1988; Prior e Bornhold, 1988; Postma, 1990; Reading e Collinson, 1996). Nesta situação, depósitos de fluxos de detritos ou fluxos liquefeitos podem evoluir para correntes de turbidez de alta densidade e estas para baixa densidade ainda na frente deltaica (Lowe, 1982; Kleinspehn et al., 1984; Nemec e Steel, 1984; Marzo e Anadón, 1988), gerando depósitos gravitacionais e turbidíticos retrabalhados por ondas e associados aos depósitos de barras de desembocadura, como descrito por Kleinspehn et al. (1984), Nemec e Steel (1984), Marzo e Anadón (1988), Postma e Cruickshank (1988), e observado na Unidade Conglomerática 1 e parte basal da Unidade Areno-Lamítica 1 da Formação Camarinha.

$O$ intenso retrabalhamento por ondas das fácies subaquosas da Formação Camarinha, aliado à ocorrência, ainda que pontual, de icnofósseis descritos por Ciguel et al. (1992) como Gordia arcuata Ksiazkiewicz, Planolites montanus Richter, Skolithos Haldemann e cubicnia, sugere caráter marinho para o ambiente de deposição das fácies medianas a distais dos leques. Na Área Norte, paleocorrentes com padrão nitidamente bidirecional podem sugerir alguma influência por marés.

$\mathrm{Na}$ transição da Unidade Areno-Lamítica 1 para a Unidade Conglomerática 2 da Formação Camarinha, são observados níveis argilosos laminados associados ao topo de depósitos de sheetflood. Esses tipos de depósitos, embora incomuns em regiões medianas de leques, podem ocorrer se pequenas depressões sobre a superfície do leque permitirem uma deposição por decantação após o período de enchentes (Blair, 1987), ou como fácies de canais abandonados (Collinson, 1996). Estes depósitos podem ser retrabalhados pelos fluxos seguintes, gerando intraclastos preservados nos níveis sobrepostos, conforme observado localmente na Formação Camarinha.

Ainda que o gradiente nas regiões distais subaquosas dos fandeltas da Formação Camarinha fosse suficientemente baixo para permitir a ação de ondas, é provável que na área-fonte esse gradiente fosse mais elevado, dado o alto grau de imaturidade dos sedimentos, evidenciando deposição rápida após transporte curto, a partir de áreas-fonte próximas. Estas fontes foram anteriormente definidas por Popp (1972) como estando a nordeste, sendo constituídas pelo Grupo Açungui (incluindo a Formação Água Clara). Entretanto, ao longo deste trabalho verificou-se também contribuição dos complexos Atuba e Três Córregos na composição dos sedimentos da Formação Camarinha, além de clastos de arenitos, siltitos e lamitos provenientes da própria formação.

A determinação do tipo de clima vigente na área-fonte à época da deposição dos sedimentos da Formação Camarinha fica dificultada pelo fato de que os processos de erosão e sedimentação atuantes nos continentes à época atribuída para a existência da bacia (transição NeoproterozóicoEocambriano) comportavam-se como de climas áridos, devido à ausência de cobertura vegetal. Mesmo a presença de grãos e clastos de composição feldspática e carbonática não pode ser 
considerada conclusiva, uma vez que estes materiais podem ser preservados mesmo sob condições de climas mais úmidos se houver relevo de gradiente acentuado na fonte.

A análise petrográfica dos sedimentos da Formação Camarinha revela a presença de acentuada pigmentação por óxidos e hidróxidos de ferro, os quais podem ter origem intempérica já à época de sedimentação (Collinson, 1996), contribuindo posteriormente na cimentação das rochas. A diagênese das mesmas parece ter atingido condições de profundidade de soterramento equivalentes ao estágio de Mesodiagênese, evidenciado pela formação de cimento carbonático e mais raramente silicático, substituições minerais como feldspatos por minerais carbonáticos e possível formação de minerais argilosos como illita, caso possa ser confirmada a detecção da mesma na análise por Difratometria de Raios-X. Posteriormente, estágios de telodiagênese causada por soerguimentos e exposição dos sedimentos podem ter sido os responsáveis por alteração intempérica na forma de alteração de feldspatos para minerais argilosos como caulinita, dissolução de minerais instáveis e novas formações de óxidos e hidróxidos de ferro.

Intensa alteração é verificada nas rochas da Formação Camarinha nas imediações das falhas transcorrentes que afetam a área, como a Falha da Lancinha. Esta alteração foi verificada na análise petrográfica como consistindo em misturas de minerais como quartzo, "sericita" (mica fina, podendo tratar-se de illita a ser confirmada) e calcita neoformadas e preenchendo fraturas $\mathrm{e}$ interstícios da rocha examinada. Este tipo de alteração pode ser chamado de alteração hidrotermal do tipo "Sericítica", "Filítica" ou "Fílica" (Burnham, 1962; Hemley e Jones, 1964; Meyer e Hemley, 1967; Pirajno, 1992; Thompson et al., 1996), gerada pela percolação de fluidos aquecidos inclusive através de falhas.

Esta alteração pode estar relacionada à atuação de falhamentos transcorrentes como a Falha da Lancinha, cujos efeitos sobre as rochas da Formação Camarinha serão discutidos a seguir.

\subsection{TECTÔNICA DEFORMADORA}

A atuação da Falha da Lancinha imprimiu nítida deformação nos sedimentos da Formação Camarinha, tendo sido analisada no Cap.5 deste trabalho. A partir da análise de estereogramas e de estiramento de clastos, verificou-se que esta deformação tem natureza rúptil-dúctil e caráter lateral direito, associada ao deslocamento principal já conhecido da Falha da Lancinha. As estruturas geradas foram interpretadas com base na đisposição espacial de seu conjunto e em suas relações angulares entre si e com o falhamento principal, constituindo estruturas previstas no Modelo de Riedel, tais como: dobras escalonadas, falhas sintéticas e antitéticas, fraturas X e T. Essas estruturas já haviam sido detectadas no embasamento da Formação Camarinha por Fassbinder (1990) e Fassbinder et al. (1994), sendo aqui verificada sua ocorrência também na Formação Camarinha. $O$ 
caráter compressivo já estabelecido por estudos anteriores para o movimento lateral direito da Falha da Lancinha e lineamentos associados evidencia-se ainda no soerguimento de blocos do embasamento da Formação Camarinha como na região de Purunã (Área Sul) e no bloco entre as áreas Sul e Norte. A falta de condições para o levantamento de perfis transversais à bacia em quantidade e proximidade suficientes não permitiu o cálculo da quantidade de deslocamento da Falha da Lancinha na região segundo o método de integração da deformação descrito em Fiori (1997).

Os dobramentos existentes na Formação Camarinha já haviam sido observados por diversos autores e questionados por outros, conforme referido no Cap. 2 deste trabalho. No presente trabalho, a ocorrência desses dobramentos foi confirmada, porém como estruturas escalonadas associadas ao sistema de deformação transcorrente, manifestando-se na forma de sinclinais com fechamento para NE e eixo oblíquo à zona de falhamento principal, eventualmente com clivagem de fratura e foliação plano-axial associadas.

A deformação lateral esquerda detectada em seixos estirados da Formação Camarinha por Moritz Jr. e Fiori (1987) foi atribuída pelos próprios autores a uma possível fase de reativação da Falha da Lancinha no Fanerozóico, interpretação esta contestada por Fassbinder (1990). Outra possível manifestação dessa reativação ocorre no bloco ao norte da Falha da Lancinha na Área Sul da Formação Camarinha, onde a disposição dos acamamentos medidos configura uma estruturação aparentemente cônica, podendo constituir uma feição resultante de arrasto do flanco noroeste da dobra escalonada ao longo da Falha da Lancinha por ocasião de reativação lateral esquerda da mesma.

A presença ou não de metamorfismo nas rochas da Formação Camarinha tem sido uma questão controversa. De acordo com o exposto no Cap. 2 do presente trabalho, alguns autores não consideraram a formação como metamórfica, enquanto outros consideram a existência de um anquimetamorfismo. Ao longo deste trabalho, não foi detectada a presença de minerais metamórficos na análise petrográfica, sendo as micas observadas de caráter detrítico (dispostas nos planos de acamamento) ou hidrotermal (disseminadas e preenchendo fraturas, sem qualquer orientação preferencial). A análise difratométrica efetuada, que revelou a presença de mica e/ou illita, não permitiu a discriminação de caráter diagenético ou metamórfico para as mesmas, caracterização esta que só pode ser feita com o estudo dos índices de cristalinidade. Como a atuação de um anquimetamorfismo pode gerar minerais não visíveis em escala de lâmina, estudos futuros visando a determinação do indice de cristalinidade das micas/illitas presentes, com apoio de Microscopia Eletrônica de Varredura, poderão ser de grande utilidade para a determinação da presença ou não de anquimetamorfismo nas rochas da formação. 


\subsection{IDADES}

Embora a bacia da Formação Camarinha venha sendo colocada na transição Neoproterozóico-Eocambriano desde Muratori et al. (1967) e Almeida (1969), como relacionada aos estágios finais da orogênese brasiliana, fato este corroborado por seu pouco ou nenhum metamorfismo e seu posicionamento estratigráfico de caráter discordante entre os metassedimentos do Pré-Cambriano paranaense e os sedimentos da Bacia do Paraná, são poucos os dados existentes que permitem estabelecer uma idade mais precisa para a mesma, seja na forma de datações radiométricas, seja como ocorrência de fósseis. Idades entre Vendiano e Tommotiano, ou entre Neocambriano e Eo-Ordoviciano foram estimadas para a bacia por alguns autores, conforme exposto nos caps. 2 e 6 deste trabalho.

A isócrona $\mathrm{Rb}-\mathrm{Sr}$ obtida no presente trabalho revelou idades ainda mais jovens, de $432.8 \pm$ 6.3 $\mathrm{Ma}$ a $437.7 \pm 2.5 \mathrm{Ma}$ (dependendo do tratamento dado à isócrona), que representam o NeoOrdoviciano. Embora qualquer evento de alteração posterior dos sedimentos possa ter proporcionado a re-homogeneização isotópica responsável por essa idade, também alguma reativação fanerozóica do sistema transcorrente da Falha da Lancinha pode ter facilitado a percolação de fluidos hidrotermais que alteraram os sedimentos da Formação Camarinha, abrindo o sistema e gerando a idade obtida.

O posicionamento estratigráfico da Formação Camarinha na transição NeoproterozóicoEocambriano pode então ser mantido, havendo no entanto necessidade de se prosseguirem os estudos e tentativas de determinação de idade via novos dados de datação radiométrica ou pesquisa de outras ocorrências de fósseis, microfósseis ou icnofósseis.

\subsection{MODELOS CLASSIFICATÓRIOS E DISCUSSÃO}

A classificação do tipo de bacia que acomoda as rochas da Formação Camarinha vem sendo objeto de diversas discussões. Autores citados no Cap. 2 deste trabalho consideraram a bacia como do tipo foreland retro-arco, enquanto outros autores propuseram a origem da bacia como relacionada aos falhamentos transcorrentes, na forma de grabens pós-tectônicos ou bacia de strikeslip transtrativa (pull-apart).

O atual estágio de conhecimento disponível e até aqui obtido em estudos sobre a Formação Camarinha, inclusive no presente trabalho, não permite o estabelecimento definitivo de um único modelo de tectônica formadora para a bacia. Entretanto, a ocorrência da mesma em um contexto associado a um embasamento constituído por um cinturão orogênico brasiliano, a proximidade com um possível arco magmático, o tipo de preenchimento sedimentar 
verificado e a tectônica deformadora analisada permitem uma aproximação a alguns tipos de modelos evolutivos relacionados a ambientes tardi-orogênicos a pós-orogênicos, em condições tanto compressivas como distensivas. Dentre esses modelos, podem ser discutidos os já anteriormente propostos de foreland retro-arco e pull-apart, além de novas alternativas que podem se relacionar ao contexto analisado, como modelos de bacias de piggyback, transpressivas e extensivas.

Nenhum desses modelos pode, até o momento, ser adotado como definitivo, devido à falta de diversas evidências mais conclusivas para cada um, sendo todos então analisados em seus prós e contras, com indicações de metas a serem buscadas para eu melhor aperfeiçoamento.

\subsubsection{Modelos tardi-orogênicos}

\section{a. Bacia de Foreland Retro-arco: (Fig.7.1)}

PRÓS:

- Preenchimento sedimentar compatível;

- Localização na região do retro-arco relacionada ao Complexo Granítico Três Córregos;

- Formação posterior ao ápice da Orogenia Brasiliana;

- Evidências de uma tectônica sin-sedimentar representada pela presença de estruturas sedimentares sin-tectônicas, e pela ocorrência de progradações e retrogradações do preenchimento sedimentar;

CONTRAS:

- Segundo os conceitos mais aceitos de bacias de foreland (Allen et al., 1986; Miall, 1995 ; Jordan, 1995), as mesmas situam-se adjacentemente ao cinturão orogênico (principal ou de retro-arco), estando posicionada entre o mesmo e o cráton adjacente. Não é o caso da bacia da Formação Camarinha, a qual, embora esteja muito próxima do embasamento constituído pelo Complexo Atuba e não tenha seus pacotes adjacentes às bordas originais preservados (situação em que poderiam situar-se parcialmente assentados diretamente sobre o Complexo Atuba, o qual constituiria o foreland), grande parte da mesma ocorre assentada sobre o próprio cinturão orogênico (representado pelos metassedimentos das formações Capiru, Votuverava e Água Clara), não se encontrando, portanto, na região definida como foreland.

- Por encontrar-se sobre o cinturão orogênico, a bacia poderia constituir-se em uma bacia-satélite de um sistema de foreland, isto é, uma bacia originalmente de foreland que foi segmentada e soerguida pelas cunhas do cinturão orogênico enquanto se propagam por sob a bacia, conforme definido por Ricci-Lucchi (1986), Allen et al. (1986) e Allen e Allen (1990). Entretanto, neste 


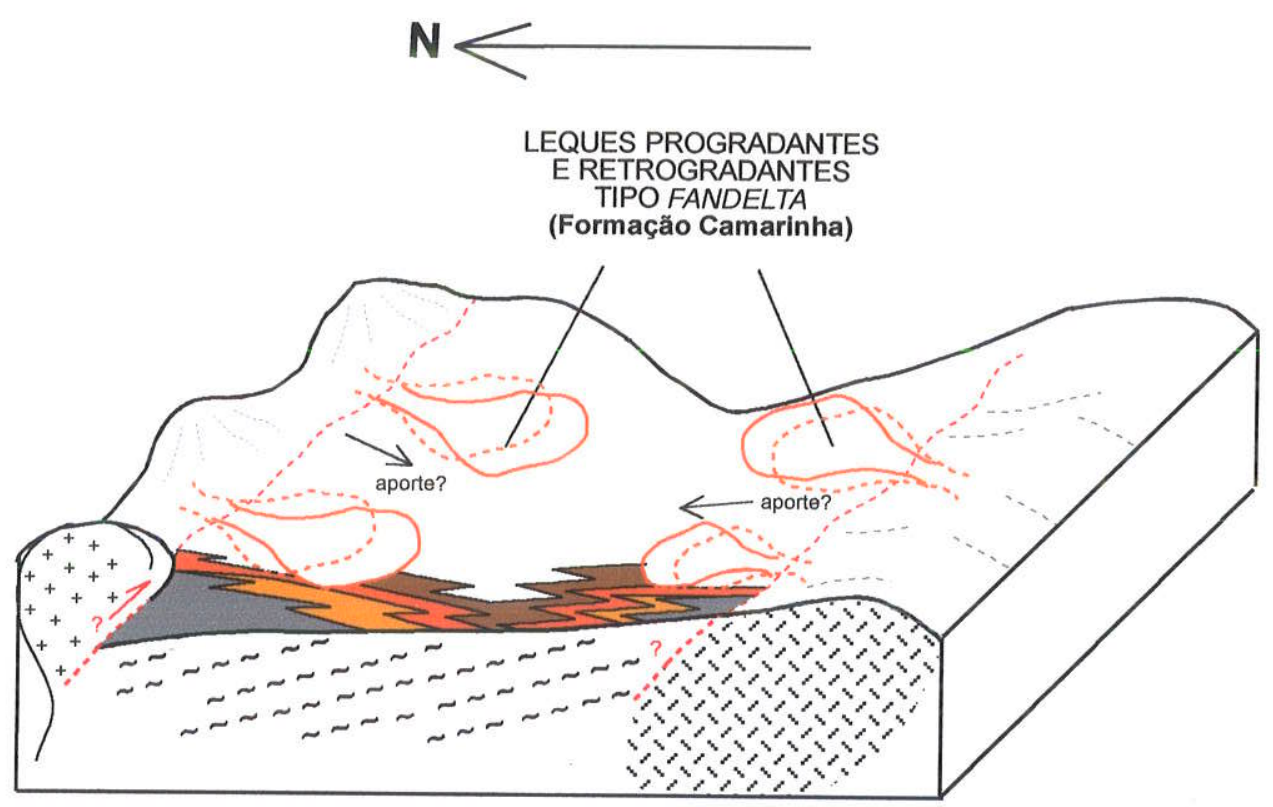

\begin{tabular}{|c|c|}
\hline & CONVENÇÕES \\
\hline & FORMAÇÃO CAMARINHA \\
\hline & Unidade Areno-Lamítica 2 \\
\hline & Unidade Conglomerática 2 \\
\hline & Unidade Areno-Lamítica 1 \\
\hline & Unidade Conglomerática 1 \\
\hline & EMBASAMENTO DA FORMAÇÃO CAMARINHA \\
\hline$+\quad+$ & Complexo Granítico Três Córregos \\
\hline$\sim \sim$ & $\begin{array}{l}\text { Núcleo Betara, Formações Água Clara, Votuverava } \\
\text { e Capiru, Granitos do Cerne e Passa Três }\end{array}$ \\
\hline$\therefore 3$ & Complexo Atuba \\
\hline & $\begin{array}{l}\text { Possíveis limites originais da Bacia da } \\
\text { Formação Camarinha }\end{array}$ \\
\hline
\end{tabular}

Fig.7.1: Possíveis modelos para a origem da Bacia da Formação Camarinha em ambiente tardi-orogênico:bacia de foreland retro-arco

(preenchimento sedimentar por meio de leques do tipo fandelta progradantes e retrogradantes, adjacentemente ao cinturão retro-arco durante os estágios finais compressivos da orogênese brasiliana; para maior clareza, optou-se por representar o preenchimento sedimentar parcialmente e omitir as fraturas e lineamentos préexistentes no embasamentoda Formação Camarinha, posteriormente reativadas pela tectônica de cisalhamento transcorrente associada à Falha da Lancinha) 
- caso, os pacotes sedimentares da bacia deveriam encontrar-se muito mais deformados, apresentando dobras e falhas compressivas, o que não se verifica;

- Não ocorrem discordâncias intraformacionais indicativas de atividade sin-tectônica relacionada ao avanço das cunhas do cinturão orogênico durante a sedimentação, nem tampouco indicadores suficientes de direções de aporte de sedimentos que caracterizem a região frontal e mais ingreme (front) destas cunhas como fonte principal dos mesmos, que neste caso deveria estar situada a noroeste da bacia;

- Como os pacotes sedimentares adjacentes às bordas originais da bacia não se encontram preservados, não é possível verificar se essas bordas são efetivamente limitadas por cunhas do cinturão orogênico, caso em que seriam constituídas por falhas de cavalgamento ou inversas, ou ainda dobramentos.

b. Bacia de Piggyback: (Fig.7.2)

PRÓS:

- Preenchimento sedimentar compatível;

- Localização sobre o cinturão orogênico, que constitui seu embasamento;

- Formação posterior ao ápice da Orogenia Brasiliana, caso em que constituiria uma bacia formada e preenchida durante intervalos de quiescência entre pulsos finais e pouco intensos de atividade do cinturão orogênico, como no caso de diversas bacias dos Apeninos italianos (RicciLucchi, 1986; Massari e Colella, 1988; Capuano, 1993; Cipollari e Cosentino, 1993; Pieri et al., 1994; Jordan, 1995). Essas bacias, preenchidas por fandeltas e turbiditos, são consideradas pelos referidos autores como tardi a pós-orogênicas, em uma extensão do conceito original de Ori e Friend (1984) para bacias de piggyback;

- Evidências de uma tectônica sin-sedimentar representada pela presença de estruturas sedimentares sin-tectônicas, e pela ocorrência de progradações e retrogradações do preenchimento sedimentar;

CONTRAS:

- Assim como no modelo de bacia de foreland, não ocorrem discordâncias intraformacionais indicativas de atividade sin-tectônica relacionada ao avanço das cunhas do cinturão orogênico durante a sedimentação, nem fácies deformadas por este avanço e tampouco indicadores sufficientes de direções de aporte de sedimentos que caracterizem o front das cunhas como fonte principal dos mesmos a noroeste da bacia;

- Também como no modelo de bacia de foreland, os pacotes sedimentares adjacentes às bordas originais da bacia não se encontram preservados, não sendo possivel verificar se essas bordas 
N<smiles>C1CC1</smiles>
LEQUES PROGRADANTES
E RETROGRADANTES
TIPO FANDELTA
(Formação Camarinha)

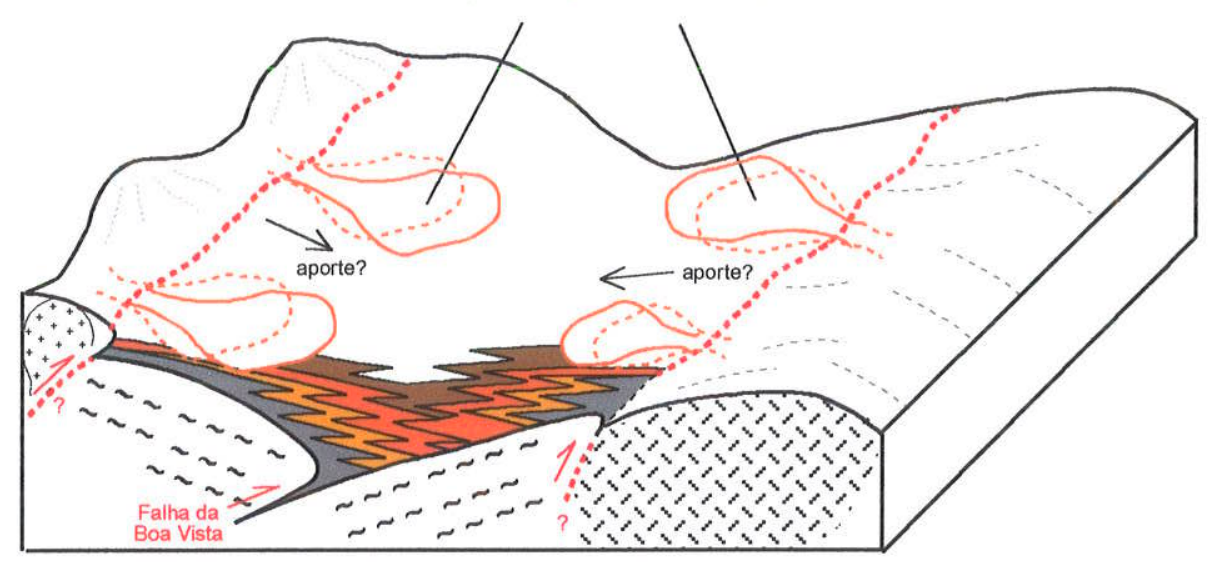

\begin{tabular}{|c|c|}
\hline & CONVENÇŐES \\
\hline & FORMAÇÃO CAMARINHA \\
\hline & Unidade Areno-Lamítica 2 \\
\hline & Unidade Conglomerática 2 \\
\hline & Unidade Areno-Lamítica 1 \\
\hline & Unidade Conglomerática 1 \\
\hline & EMBASAMENTO DA FORMAÇÃO CAMARINHA \\
\hline++ & Complexo Granítico Três Córregos \\
\hline & $\begin{array}{l}\text { Núcleo Betara, Formações Água Clara, Votuverava } \\
\text { e Capiru, Granitos do Cerne e Passa Três }\end{array}$ \\
\hline & Complexo Atuba \\
\hline & $\begin{array}{l}\text { Possíveis limites originais da Bacia da } \\
\text { Formação Camarinha }\end{array}$ \\
\hline
\end{tabular}

Fig.7.2: Possíveis modelos para a origem da Bacia da Formação Camarinha em ambiente tardi-orogênico:bacia de piggyback

(preenchimento sedimentar por meio de leques do tipo fandelta progradantes e retrogradantes, entre cunhas de empurrão relacionadas aos estágios finais compressivos da orogênese brasiliana; para maior clareza, optou-se por representar o preenchimento sedimentar parcialmente e omitir as fraturas e lineamentos préexistentes no embasamentoda Formação Camarinha, posteriormente reativadas pela tectônica de cisalhamento transcorrente associada à Falha da Lancinha); 
- são efetivamente limitadas pelas cunhas do cinturão orogênico, na forma de falhas de cavalgamento ou inversas, ou de dobramentos.

\section{JUSTIFICATIVAS À FALTA DE EVIDENCIAS E PROPOSTAS PARA EVENTUAL CONFIRMAÇÃO DOS MODELOS TARDI-OROGENICOS:}

- Em bacias tardi-orogênicas, formadas e preenchidas durante intervalos de quiescência entre pulsos finais e pouco intensos de atividade do cinturão orogênico, a deformação de pacotes sedimentares e formação de discordâncias pode ser muito incipiente e ocorrer de forma local ou restrita apenas às margens da bacia, nem sempre podendo ser detectadas (Allen et al., 1986; Ricci-Lucchi, 1986; Anadón et al., 1986; Miall, 1990; Jordan, 1985), podendo também estar encobertas ou mascaradas;

- As direções de paleocorrentes obtidas no presente trabalho não são em número suficiente nem representativo para uma análise e interpretação confiáveis dos sentidos principais de aporte sedimentar, sejam estes de noroeste para sudeste ou de sudeste para noroeste. Além disso, nem sempre os fronts do cinturão orogênico constituem fontes únicas ou principais para o aporte de sedimentos, podendo ao invés disso funcionar como barreiras ao aporte vindo da direção oposta (Allen et al., 1986; Allen e Allen, 1990). Conforme o estágio evolutivo da bacia, também é possível a ocorrência de aporte sedimentar vindo não só dos fronts do cinturão, como também da direção oposta (Ricci-Lucchi, 1985, 1986; Jordan, 1995);

- Futuras pesquisas na bacia da Formação Camarinha podem ser direcionadas para a obtenção ou descarte das evidências acima citadas como necessárias, seja por meio de estudos efetuados em áreas mais abrangentes e em escalas de mais detalhe para detecção e caracterização das fácies de borda, das eventuais discordâncias e dos sentidos principais de aporte sedimentar, seja na forma de análises fotogeológicas e geofisicas, a fim de se caracterizar melhor a localização e natureza das estruturas que constituiriam os limites originais da bacia (dobras ou falhas de cavalgamento e inversas).

\subsubsection{Modelos pós-orogênicos}

a. Bacia de Strike-slip transtrativa (pull-apart): (Fig.7.3) PRÓS:

- Preenchimento sedimentar compatível;

- Localização em uma região submetida a intensa atividade de cisalhamento transcorrente;

- Formação posterior ao ápice da Orogenia Brasiliana; 


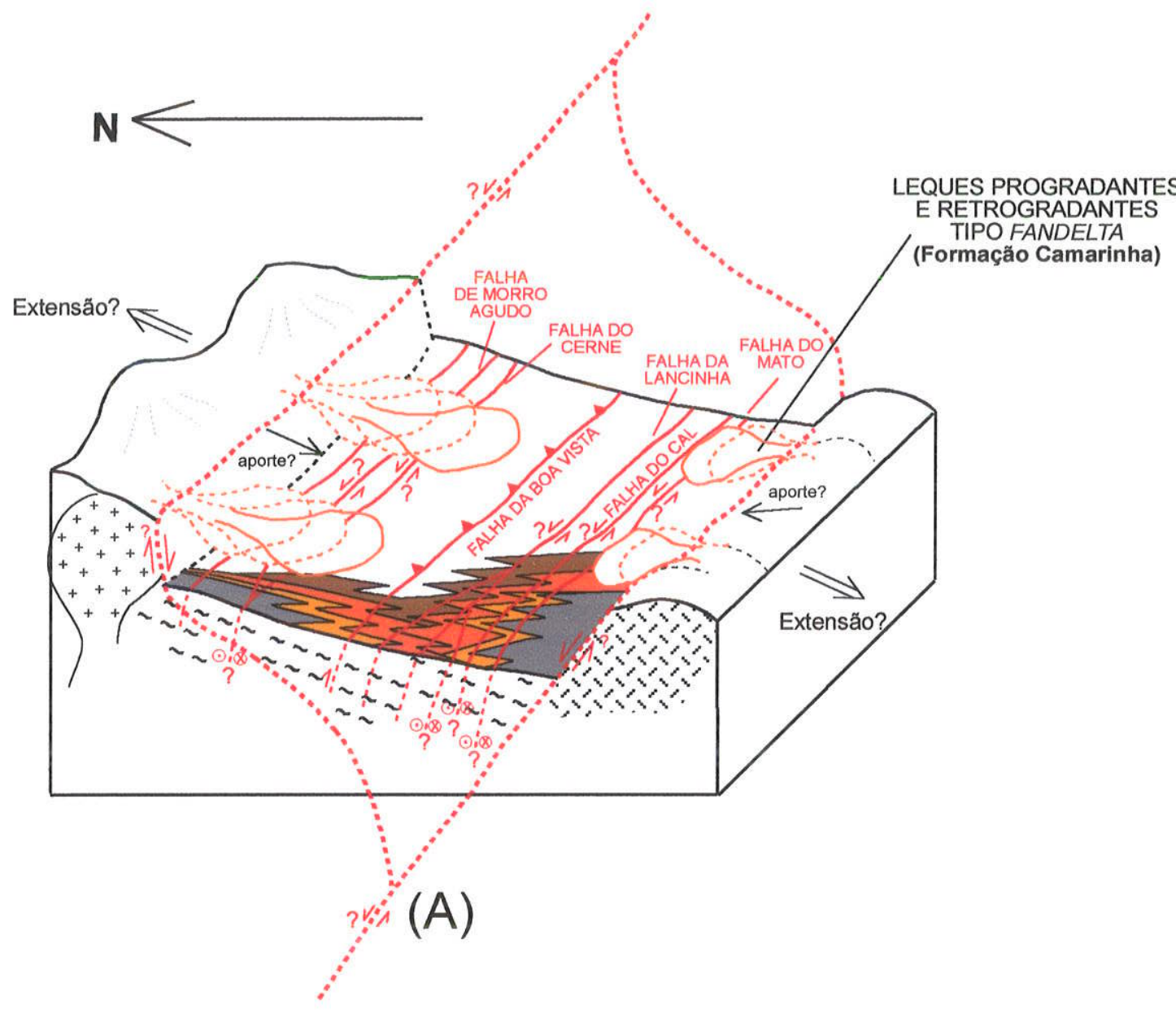

\begin{tabular}{|c|c|}
\hline & CONVENÇÕES \\
\hline & FORMAÇÃO CAMARINHA \\
\hline & Unidade Areno-Lamítica 2 \\
\hline & Unidade Conglomerática 2 \\
\hline & Unidade Areno-Lamítica 1 \\
\hline & Unidade Conglomerática 1 \\
\hline & EMBASAMENTO DA FORMAÇÃO CAMARINHA \\
\hline++ & Complexo Granítico Três Córregos \\
\hline & $\begin{array}{l}\text { Núcleo Betara, Formações Água Clara, Votuverava } \\
\text { e Capiru, Granitos do Cerne e Passa Três }\end{array}$ \\
\hline & Complexo Atuba \\
\hline & $\begin{array}{l}\text { Possíveis limites originais da Bacia da } \\
\text { Formação Camarinha }\end{array}$ \\
\hline & Falhas de cavalgamento com indicação de movimento \\
\hline & Falhas transcorrentes com indicação de movimento \\
\hline
\end{tabular}

Fig.7.3: Possíveis modelos para a origem da Bacia da Formação Camarinha em ambiente pós-orogênico:bacia de strike-slip transtrativa (preenchimento sedimentar por meio de leques do tipo fandelta progradantes e retrogradantes, em depressão gerada por extensão associada ao sistema transcorrente da Falha da Lancinha; para maior clareza, optou-se por representar o preenchimento sedimentar parcialmente) 
- Evidências de uma tectônica sin-sedimentar representada pela presença de estruturas sedimentares sin-tectônicas, e pela ocorrência de progradações e retrogradações do preenchimento sedimentar;

CONTRAS:

- Os lineamentos transcorrentes associados ao sistema da Falha da Lancinha deveriam constituir as bordas originais da bacia da Formação Camarinha, controlando o contato da mesma com seu embasamento (Complexo Atuba, Núcleo Betara, metassedimentos das formações Capiru, Votuverava e Água Clara, e rochas graníticas), e representando o limite entre estas últimas como áreas-fonte e as fácies sedimentares subaéreas proximais às bordas da bacia. Entretanto, nem sempre estes lineamentos controlam o contato da Formação Camarinha com o seu embasamento, ocorrendo por vezes porções da formação em ambos os lados das falhas ou até distantes das mesmas (Mapa Geológico, Anexo I), chegando estas falhas por vezes até mesmo a truncar os pacotes sedimentares constituintes da formação;

- Ainda que os limites da bacia da Formação Camarinha como bacia de pull-apart pudessem estar relacionados a quaisquer outros lineamentos transcorrentes de seu embasamento que não os lineamentos mais próximos, não se verificam na região quaisquer tipos de indicadores cinemáticos relacionados à abertura da mesma, a qual teria ocorrido por extensão associada a uma movimentação lateral esquerda anterior à lateral direita principal já conhecida do sistema transcorrente, uma vez que esta última constitui a tectônica deformadora dos sedimentos que constituem a formação, conforme análise efetuada neste trabalho. Para a abertura de uma bacia originalmente maior que a atual Formação Camarinha, a movimentação lateral esquerda, caso houvesse ocorrido, deveria ser significativa o suficiente para deixar alguns indicadores remanescentes, ainda que mascarados pela movimentação lateral direita posterior. Também não ocorrem quaisquer indicadores cinemáticos que possam auxiliar na determinação de direções de paleoesforços de abertura característicos de uma extensão;

- Em bacias de pull-apart, os depósitos proximais a suas bordas originais (conglomerados e brechas de leques depositados por processos de fluxos de detritos e sheet-floods, que seriam os equivalentes à porção proximal da Unidade Conglomerática 1) deveriam ocorrer adjacentemente aos lineamentos transcorrentes se os mesmos constituíssem as bordas originais da bacia. No entanto, esses depósitos de borda não se encontram preservados, ocorrendo apenas porções das regiôes medianas a distais dos leques (unidades Conglomerática 1 e Unidade ArenoLamítica 1) nas partes mais basais da formação atualmente preservada. Os depósitos subaéreos de fluxos de detritos e sheet-floods da Unidade Conglomerática 2 não representam unidades adjacentes às bordas originais, e sim o resultado de progradações dos leques para o interior da bacia; 
- Sendo bacias de pull-apart bastante profundas e com gradientes muito elevados, os depósitos continentais costumam progradar diretamente para ambientes de águas profundas em taludes (Massari e Colella, 1988), o que não se verifica na bacia da Formação Camarinha, na qual ocorrem espessos depósitos de frente deltaica em águas pouco profundas sujeitas a ação de ondas nas porções distais dos leques, representados pelos sedimentos das unidades ArenoLamítica 1 e 2;

- Não ocorrem discordâncias intraformacionais indicativas de atividade sin-tectônica relacionada à continuidade do deslocamento das falhas que delimitam as bordas da bacia durante a sedimentação;

- Tendo bacias de pull-apart natureza transtrativa, por se formarem em zonas de encurvamento ou oversteps distensivos na zona de cisalhamento (Ballance e Reading, 1980; Mann et al., 1983; Biddle e Christie-Blick, 1985; Nilsen e Sylvester, 1995), é comum (embora não obrigatória) a ocorrência de vulcanismo associado (Reading, 1980; Einsele, 1992; Ingersoll e Busby, 1995). No caso da Formação Camarinha, se a mesma fosse efetivamente uma bacia de pull-apart transtrativa, seria de se esperar que sua abertura, ocorrendo em uma região próxima ao antigo arco magmático e ainda sujeita a intrusões de granitos sin, tardi e pós-orogênicos, fosse acompanhada de atividade vulcânica como nas bacias de Castro, Guaratubinha e Campo Alegre, estas reconhecidamente de pull-apart, o que não se verifica;

\section{b. Bacia de Strike-slip transpressiva: (Fig.7.4)}

PRÓS:

- Preenchimento sedimentar compatível;

- Localização em uma região submetida a intensa atividade de cisalhamento transcorrente de caráter compressivo;

- Formação posterior ao ápice da Orogenia Brasiliana;

- Evidências de uma tectônica sin-sedimentar representada pela presença de estruturas sedimentares sin-tectônicas, e pela ocorrência de progradações e retrogradações do preenchimento sedimentar;

- Ocorrência detectada por Fassbinder (1990) de feições de caráter inverso com mergulhos de alto ângulo para NW relacionadas à Falha da Lancinha, e possibilidade de existência de uma estrutura em flor positiva proposta também por Fassbinder $(1990,1996)$, a ser confirmada na região, sendo que essas estruturas são propícias à formação deste tipo de bacia por sobrecarga flexural entre cunhas de empurrão soerguidas e ejetadas durante a compressão, de forma semelhante à formação de bacias de piggyback (Miall, 1990; Ingersoll e Busby, 1995; Nilsen e Sylvester, 1995); 


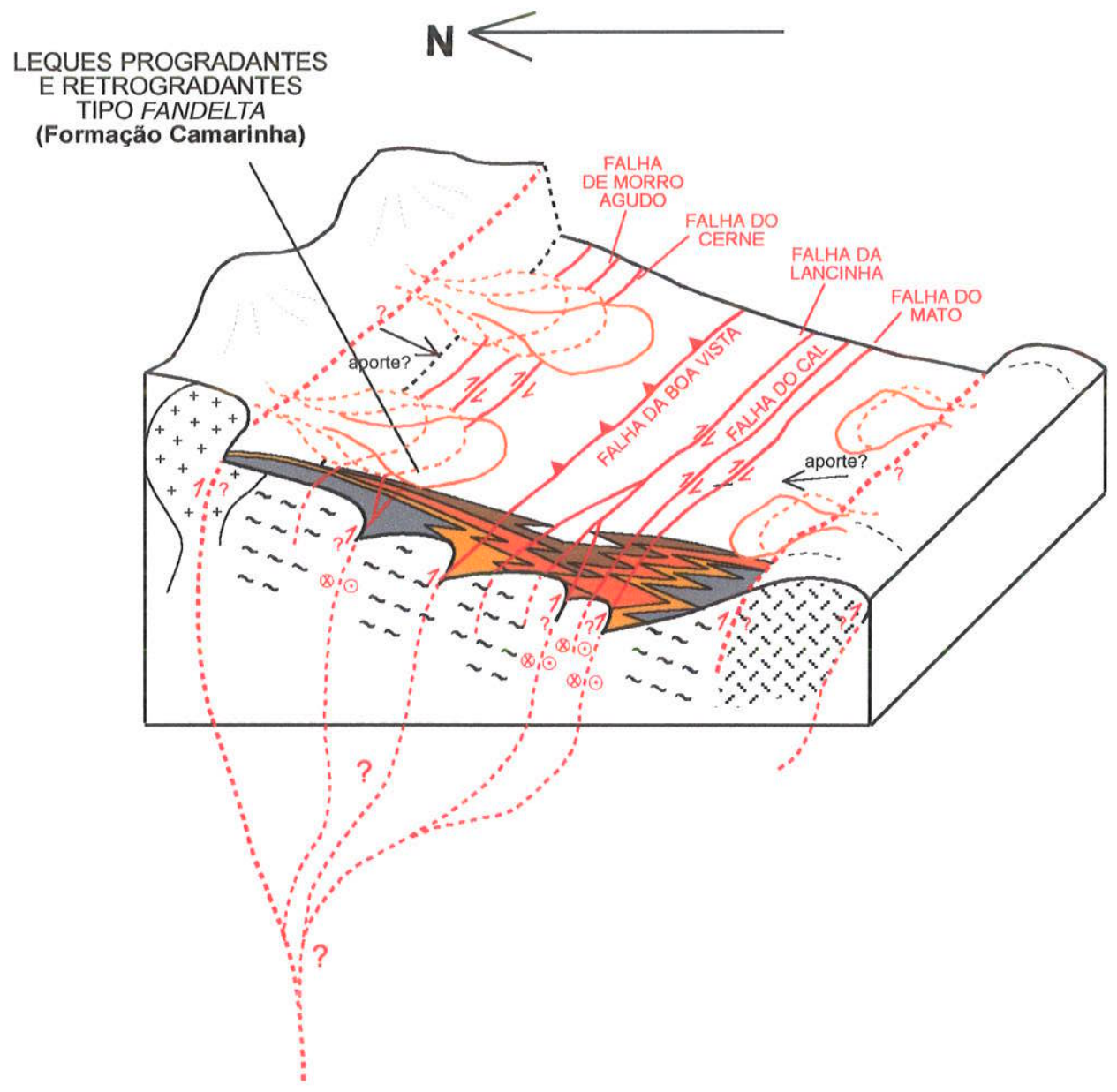

\begin{tabular}{|c|c|}
\hline & CONVENÇŐES \\
\hline & FORMAÇÃO CAMARINHA \\
\hline & Unidade Areno-Lamítica 2 \\
\hline & Unidade Conglomerática 2 \\
\hline & Unidade Areno-Lamítica 1 \\
\hline & Unidade Conglomerática 1 \\
\hline & EMBASAMENTO DA FORMAÇÃO CAMARINHA \\
\hline++ & Complexo Granítico Três Córregos \\
\hline & $\begin{array}{l}\text { Núcleo Betara, Formações Água Clara, Votuverava } \\
\text { e Capiru, Granitos do Cerne e Passa Três }\end{array}$ \\
\hline & Complexo Atuba \\
\hline & $\begin{array}{l}\text { Possíveis limites originais da Bacia da } \\
\text { Formação Camarinha }\end{array}$ \\
\hline & Falhas de cavalgamento com indicação de movimento \\
\hline & alhas transcorrentes com indicação de movimento \\
\hline
\end{tabular}

Fig.7.4: Possíveis modelos para a origem da Bacia da Formação Camarinha em ambiente pós-orogênico:bacia de strike-slip transpressiva (preenchimento sedimentar por meio de leques do tipo fandelta progradantes e retrogradantes, entre cunhas de empurrão relacionadas ao componente compressivo do deslocamento principal do sistema transcorrente da Falha daLancinha; para maior clareza, optou-se por representar o preenchimento sedimentar parcialmente) 
- Datações K-Ar efetuadas por Basei et al. (1998) de $534 \pm 16$ Ma para muscovitas de milonitos gerados pela Falha da Lancinha, e de $478 \pm 10$ e $505 \pm 10 \mathrm{Ma}$ para anquimetamorfismo em siltitos da Formação Camarinha, o que leva a crer na existência da atividade principal da falha antes da geração desse anquimetamorfismo, com um intervalo de tempo entre estes fenômenos durante o qual a bacia poderia ter se desenvolvido.

CONTRAS:

- Assim como para o modelo de bacia de pull-apart, também para uma bacia transpressiva os lineamentos transcorrentes associados ao sistema da Falha da Lancinha deveriam constituir as bordas originais da bacia da Formação Camarinha, controlando o contato da mesma com seu embasamento e representando o limite entre o mesmo como áreas-fonte e as fácies sedimentares subaéreas proximais às bordas da bacia. Conforme observado anteriormente, nem sempre estes lineamentos controlam o contato da Formação Camarinha com o seu embasamento, ocorrendo porções da formação em ambos os lados das falhas ou mesmo distantes destas (Mapa Geológico, Anexo I), chegando as falhas por vezes até mesmo a truncar os pacotes sedimentares constituintes da formação;

- Também como no modelo de bacia de pull-apart, os depósitos proximais às bordas originais da bacia (conglomerados e brechas de leques depositados por processos de fluxos de detritos e sheet-floods, que seriam os equivalentes à porção proximal da Unidade Conglomerática 1) deveriam ocorrer adjacentemente aos lineamentos transcorrentes se os mesmos constituíssem as bordas originais da bacia. Além disso, em bacias transpressivas esses depósitos de borda podem mostrar-se bastante deformados (Crowell, 1974a,b). Conforme já referido, esses depósitos de borda não se encontram preservados, ocorrendo apenas porções das regióes medianas a distais dos leques (unidades Conglomerática 1 e Unidade Areno-Lamítica 1) nas partes mais basais da formação atualmente preservada. A deformação verificada ocorre apenas nas imediações da Falha da Lancinha, sendo relacionada à tectônica deformadora da bacia.

- Também para este modelo não ocorrem discordâncias intraformacionais indicativas de atividade sin-tectônica relacionada à continuidade do deslocamento das falhas que delimitam as bordas da bacia durante a sedimentação, nem indicadores suficientes de direções de aporte de sedimentos que caracterizem of front das cunhas como fonte principal dos mesmos a noroeste da bacia;

- Devido ao fato de terem proposição recente, a possível existência de estrutura em flor, bem como as datações efetuadas, necessitam de mais confirmações a serem eventualmente obtidas em trabalhos futuros. 
c. Graben extensional (intermontano): (Fig.7.5)

PRÓS:

- Preenchimento sedimentar compatível;

- Grande quantidade de falhamentos de alto ângulo na região;

- Formação posterior ao ápice da Orogenia Brasiliana;

- Evidências de uma tectônica sin-sedimentar representada pela presença de estruturas sedimentares sin-tectônicas, e pela ocorrência de progradações e retrogradações do preenchimento sedimentar;

CONTRAS:

- Caso a bacia consistisse em um graben pós-orogênico formado por extensão após o colapso do cinturão orogênico (bacia "sucessora" em ambiente "intermontano" no entendimento de Ingersoll e Busby, 1995, que no entanto desaconselham o uso desse termo, por considerarem que abrange freqüentemente bacias pós-orogênicas de naturezas muito diversas), seria de se esperar que a orientação espacial da mesma fosse transversal ao cinturão orogênico, formando alto ângulo com o mesmo (Mitchell e Reading, 1986; Ingersoll e Busby, 1995), o que não se verifica na Bacia da Formação Camarinha, cuja orientação NE é paralela à do cinturão orogênico. Estes grabens têm sua abertura freqüentemente ocorrendo ao longo de fraturas $\mathrm{T}$ associadas a falhamentos transcorrentes (Nilsen e Sylvester, 1995), porém as fraturas $\mathrm{T}$ associadas ao sistema transcorrente da Falha da Lancinha têm direções em torno de $\mathrm{N} 55^{\circ} \mathrm{W}$ a $\mathrm{N} 68^{\circ} \mathrm{W}$, conforme verificado neste trabalho, incompatíveis portanto com a orientação espacial da bacia da Formação Camarinha.

- Ainda que ocorram diversos falhamentos de alto ângulo na região, a natureza dos mesmos é transcorrente e não de gravidade, tendo sofrido reativações distensivas somente a partir do Paleozóico.

- Como a bacia encontra-se deformada por cisalhamento transcorrente, sua abertura deve ter ocorrido anteriormente a este evento. Entretanto, não existem quaisquer evidências conhecidas de eventos extensivos anteriores à fase principal do cisalhamento transcorrente relacionado à Falha da Lancinha na região.

- Estas bacias também costumam apresentar vulcanismo associado, geralmente de natureza riolítico-andesítica (Tseysler, 1973; Miall, 1978c; Ingersoll e Busby, 1995), o que não se yerifica na Formação Camarinha. 


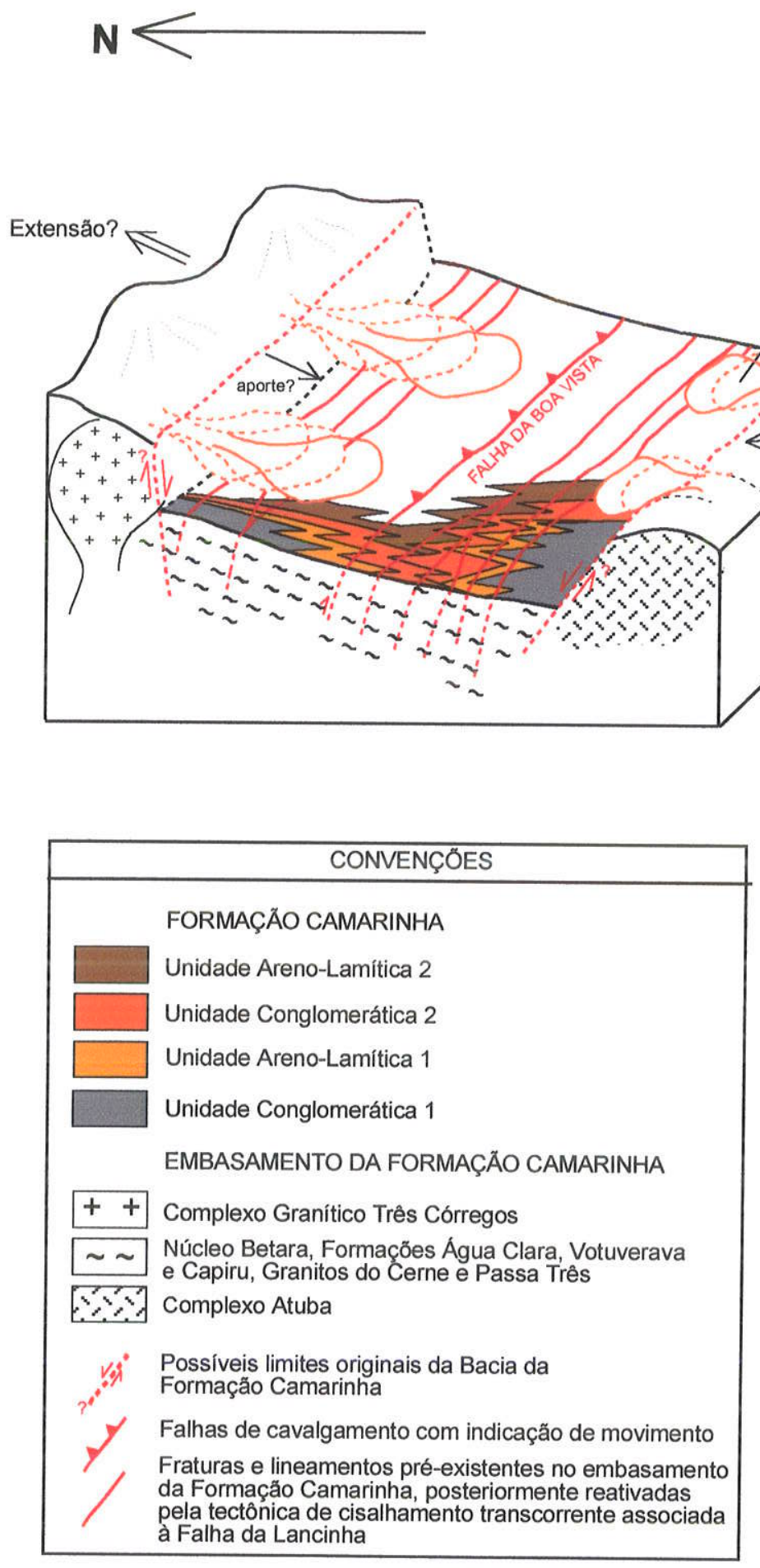

Fig.7.5: Possíveis modelos para a origem da Bacia da Formação Camarinha em ambiente pós-orogênico:graben extensional (intermontano) (preenchimento sedimentar por meio de leques do tipo fandelta progradantes e retrogradantes, em depressão gerada por extensão associada ao colapso do cinturão orogênico; para maior clareza, optou-se por representar o preenchimento sedimentar parcialmente) 


\section{JUSTIFICATIVAS À FALTA DE EVIDENCIAS E PROPOSTAS PARA EVENTUAL} CONFIRMAÇÃO DOS MODELOS PÓS-OROGENICOS:

- Os indicadores cinemáticos, de vulcanismo, de fácies proximais às bordas originais (deformadas ou não) e de fácies de águas profundas podem estar mal preservados, além de poderem ocorrer em regiões mais distantes da estudada neste trabalho. Do mesmo modo, as discordâncias podem ser apenas locais (Christie-Blick e Biddle, 1985; Miall, 1990; Allen e Allen, 1990) ou estar encobertas ou mascaradas. Conforme referido anteriormente, o número de medidas de paleocorrentes levantado é muito pequeno para que se faça qualquer consideração mais conclusiva sobre os sentidos principais de aporte;

- Assim como para os modelos tardi-orogênicos, também no caso dos modelos pós-orogênicos futuras pesquisas na bacia da Formação Camarinha podem ser direcionadas para a obtenção ou descarte das evidências acima consideradas como necessárias. Isto pode ser feito tanto por meio de estudos efetuados em áreas mais abrangentes e em escalas de mais detalhe para deteçãa e caracterização dos indicadores cinemáticos e de aporte sedimentar, das eventuais discordâncias e das fácies vulcânicas, de borda e de águas profundas, quanto na forma de análises fotogeológicas e geofísicas, a fim de se caracterizar melhor a localização e natureza das estruturas que constituiriam os limites originais da bacia (falhas transcorrentes, normais ou inversas, possível estrutura em flor).

Parte do preenchimento sedimentar da bacia da Formação Camarinha foi erodida devido a soerguimentos sofridos desde a deformação transcorrente de caráter compressivo proporcionada pelo sistema da Falha da Lancinha, sendo que os pacotes atualmente expostos ficaram preservados em baixos estruturais gerados pelas reativações do sistema transcorrente no Paleozóico (Fig.7.6). A bacia da Formação Camarinha pode ter sido originalmente muito maior, conforme atesta seção sísmica da PETROBRÁS apresentada por Assine (1996), efetuada na região sul do Estado do Paraná, próximo ao limite com o Estado de Santa Catarina. Esta seção apresenta uma sucessão de sedimentos em subsuperfície entre a Bacia do Paraná e o embasamento pré-cambriano, interpretada como "bacia molássica". Estudos futuros podem confirmar ou não se esta sucessão pode representar uma continuidade física em subsuperfície ou uma outra bacia correlata da Formação Camarinha.

\subsection{CORRELACCÕES}

A bacia da Formação Camarinha apresenta algumas similaridades, principalmente em termos de idade e de tipo de sedimentação, com outras bacias e ocorrências da transição Neoproterozóico-Eocambriano do Sul e Sudeste do Brasil, como as bacias de Pouso Alegre (MG), Eleutério, Pico de Itapeva, Quatis, Samambaia, Salto de Pirapora e Pirapora do Bom Jesus (SP), 


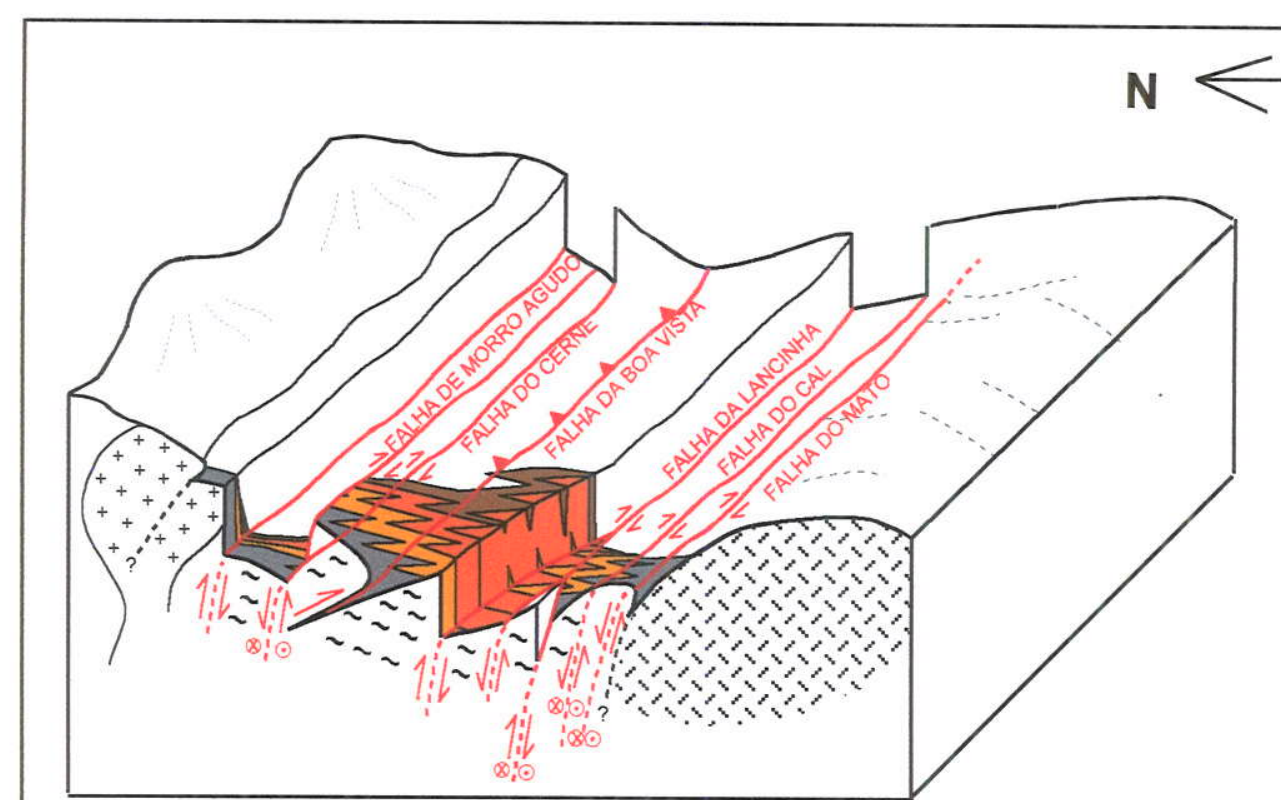

(A)

\begin{tabular}{|c|c|}
\hline & CONVENÇÕES \\
\hline & FORMAÇÃO CAMARINHA \\
\hline & Unidade Areno-Lamítica 2 \\
\hline & Unidade Conglomerática 2 \\
\hline & Unidade Areno-Lamítica 1 \\
\hline & Unidade Conglomerática 1 \\
\hline & EMBASAMENTO DA FORMAÇÃO CAMARINHA \\
\hline++ & Complexo Granítico Três Córregos \\
\hline & $\begin{array}{l}\text { Núcleo Betara, Formações Água Clara, Votuverava } \\
\text { e Capiru, Granitos do Cerne e Passa Três }\end{array}$ \\
\hline & Complexo Atuba \\
\hline & $\begin{array}{l}\text { Possiveis limites originais da Bacia da } \\
\text { Formação Camarinha }\end{array}$ \\
\hline & Falhas de cavalgamento com indicação de movimento \\
\hline
\end{tabular}

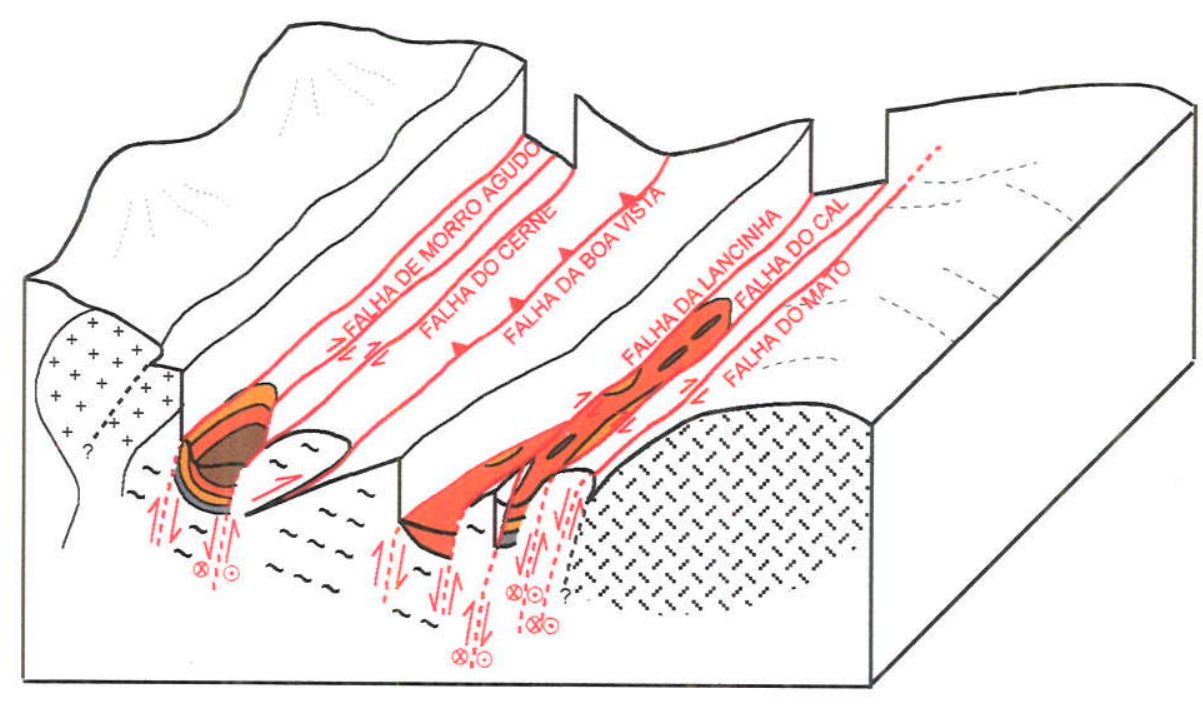

(B)

Fig.7.6: Deformação e preservação da Bacia da Formação Camarinha pela tectônica de cisalhamento transcorrente relacionada à Falha da Lancinha, sendo:

(A): Evolução da atividade transcorrente posteriormente ao preenchimento sedimentar, com deformacão e soerguimento de parte dos pacotes sedimentares constituintes da Formação Camarinha; (B): Situação atual da Formação Camarinha, após dobramentos escalonados gerados pelos falhamentos transcorrentes e erosão dos pacotes soerguidos.

(figura elaborada com exagero vertical; para maior clareza, optou-se por representar o preenchimento sedimentar parcialmente na figura $A$ e foram omitidos os depósitos da Bacia do Paraná, diques de diabásio e depósitos cenozóicos na figura $B$ ) 
Camaquã (RS) e em parte com a bacia de Itajaí (SC). Diferencia-se de outras bacias como as de Castro (PR), Guaratubinha (PR) e Campo Alegre (SC) pela ocorrência de intensa atividade vulcânica nessas últimas (as quais apresentam origem reconhecidamente associada a pull-apart), não podendo assim ser correlacionada às mesmas, apesar de terem idades próximas. Embora existam ocorrências de rochas vulcânicas na região da bacia de Camaquã, não está bem definido se as mesmas pertencem ou não ao mesmo contexto das rochas sedimentares descritas para esta bacia por Fambrini (1998).

Embora apresentem similaridade litológica com a bacia da Formação Camarinha, as ocorrências de Quatis, Samambaia, Salto de Pirapora e Pirapora do Bom Jesus necessitam ser melhor definidas em termos de origem, ambientes deposicionais e contexto geotectônico para poderem ser comparadas com a Formação Camarinha de forma mais completa. Do ponto de vista litológico e estratigráfico, a bacia da Formação Camarinha pode ser correlacionada às bacias de Eleutério, Pico de Itapeva e Camaquã, todas com sedimentação de leques passando a ambientes transicionais para subaquosos e idades similares, apresentadas no Cap. 6 deste trabalho. Como estas últimas são consideradas bacias de pull-apart, para uma correlação mais completa e definitiva com a bacia da Formação Camarinha será necessária uma melhor definição do modelo para a origem da mesma.

A bacia de Itajaí, embora também apresente sedimentação deltaica e de leques, diferencia-se da bacia da Formação Camarinha por apresentar também grande espessura de sedimentos marinhos mais profundos, na forma de sedimentos de pró-delta, plataforma, talude e leque submarino, sistemas estes não identificados na bacia da Formação Camarinha. Além disso, sua origem também não é semelhante à bacia da Formação Camarinha, sendo considerada uma bacia de foreland periférica por Rostirolla (1991) ou derivada de um rifteamento continental passivo por Citroni (1993).

A correlação proposta por Soares $(1987,1988)$ entre a bacia da Formação Camarinha e a Seqüência Antinha não foi corroborada pelo presente trabalho, uma vez que esta última apresenta-se nitidamente mais afetada por nada menos que três deformações descritas por Kops (1994), além incipientemente metamorfisada, constituindo-se em uma unidade mais antiga inserida no Grupo Açungui por Fiori (1990). As sucessões cartografadas como Formação Camarinha por Wosniak e Feola (1997) e Santos e Fávaro (1997) na região consistem na realidade em pacotes da Seqüência Antinha, não sendo portanto correlacionáveis à bacia da Formação Camarinha.

É possível que os conglomerados polimíticos e arenitos arcosianos da Formação Ervalzinho (Kops, 1994), que ocorrem na região da Seqüência Antinha, sejam correlatos à Formação Camarinha, necessitando, porém, de estudos mais detalhados sobre sua origem, ambiente de sedimentação e contexto geotectônico para a melhor verificação desta hipótese. 


\section{CONCLUSÕES}

\subsection{PRINCIPAIS CONCLUSÕES}

A bacia da Formação Camarinha constitui-se em uma bacia da transição NeoproterozóicoEocambriano no Estado do Paraná, possuindo caráter tardi a pós-orogênico com relação à orogênese Brasiliana. A bacia tem parte do Cinturão Ribeira no Estado do Paraná como seu embasamento, apresentando sedimentação constituída por leques progradantes em ambiente costeiro, ou seja, fandeltas, cujo empilhamento pode ser resumido em quatro unidades, da base para o topo: Unidade Conglomerática 1, constituída predominantemente de depósitos conglomeráticos e arenosos de fluxos gravitacionais subaquosos; Unidade Areno-Lamítica 2 , constituída na região proximal por depósitos arenosos de fluxos gravitacionais subaquosos, depósitos turbidíticos e depósitos de barra de desembocadura em frente deltaica, e na região distal por depósitos de siltitos, lamitos e ritmitos da região mais afastada das barras de desembocadura; Unidade Conglomerática 2, constituída por depósitos conglomeráticos e arenosos subaéreos de fluxos de detritos e sheet-floods, de leque progradante sobre as unidades inferiores; e Unidade Areno-Lamítica 2, constituída por novos depósitos de frente deltaica semelhantes aos da Unidade Areno-Lamítica 1, representando a parte mais distal do leque progradante. As unidades mostram contatos transicionais entre si, evidenciando uma ciclicidade deposicional indicativa de atividade tectônica sin-sedimentar na área-fonte, atividade esta corroborada pela presença de estruturas sedimentares características nos depósitos.

Os sedimentos constituintes dessas unidades são muito imaturos do ponto de vista mineralógico, e submaturos do ponto de vista textural, evidenciando transporte curto e deposição rápida a partir de áreas-fonte próximas, fontes estas representadas pelos metassedimentos das formações Água Clara (Mesoproterozóico?), Capiru e Votuverava (Neoproterozóico) e pelos complexos Atuba (Paleoproterozóico) e Três Córregos (Neoproterozóico).

A bacia foi posteriormente deformada pelo sistema transcorrente da Falha da Lancinha, a qual imprimiu estruturas rúpteis e rúpteis-dúcteis nas rochas da Formação Camarinha, na forma de estiramento de clastos e estruturas previstas pelo Modelo de Riedel, como dobras escalonadas, falhas sintéticas e antitéticas, e fraturas $\mathrm{T}$ e X. Essa deformação, de caráter lateral direito, proporcionou intensa brechação e alteração hidrotermal das rochas adjacentes à zona de falha, além de soerguimento de parte dos pacotes sedimentares, os quais ficaram expostos à erosão. Reativações dessa zona de falha podem ter sido responsáveis pelo resultado anômalo da datação geocronológica efetuada (Ordoviciano).

O posicionamento estratigráfico da bacia vem sendo mantido na transição NeoproterozóicoEocambriano com base nas relações discordantes da mesma com seu embasamento e cobertura, na 
menor deformação sofrida pela mesma e ausência aparente de metamorfismo com relação ao que se observa em seu embasamento, e na ocorrência de icnofósseis considerados característicos do período.

Não foram encontradas evidências que pudessem confirmar ou descartar em definitivo as propostas de modelos anteriores para a origem da bacia, e com base no contexto regional, sedimentar e deformacional da mesma, optou-se neste trabalho por apontar possibilidades para a mesma como formada em ambiente tardi-orogênico (bacia de foreland retro-arco ou bacia de piggyback) ou pós-orogênico (bacia de strike-slip, transtrativa ou transpressiva). Os limites originais da bacia e suas fácies proximais às bordas deverão ser descobertos, a fím de que a caracterização da origem da bacia possa ser melhor confirmada. O mesmo pode ser dito com relação à idade da bacia e a presença ou não de metamorfismo.

\subsection{ETAPAS POSTERIORES DE PESQUISA SUGERIDAS}

Pesquisas futuras visando a continuidade dos estudos sobre a bacia da Formação Camarinha devem incluir a procura e caracterização (em uma área mais abrangente e em escala mais detalhada) de indicadores cinemáticos da abertura da mesma, indicadores de aporte sedimentar, discordâncias intraformacionais e fácies vulcânicas, fácies sedimentares de águas profundas e fácies sedimentares proximais que representariam as unidades adjacentes aos limites originais da bacia. Além da investigação dessas feições em campo, a determinação e caracterização dos limites originais da bacia (tipos de falhas ou dobras) e das relações da mesma com seu embasamento em profundidade podem ser pesquisados com o auxílio de dados geofísicos (gravimétricos e sísmicos) e de fotografias aéreas e imagens de satélite. Métodos para a quantificação do deslocamento da Falha da Lancinha na região devem ser investigados, a fim de que se possa avaliar quanto do deslocamento conhecido desta falha afetou a bacia da Formação Camarinha.

O estudo de frações argilosas dos sedimentos com apoio de análise de índices de cristalinidade e microscopia eletrônica de varredura pode auxiliar na detecção de possíveis minerais metamórficos e distinção entre argilominerais e micas presentes, a fim de que se possa conhecer melhor a composição e evolução dos materiais que possam vir a ser futuramente submetidos a datação geocronológica. Investigações visando a descoberta de novas ocorrências de fósseis, microfósseis ou icnofósseis serão de grande utilidade para a determinação mais precisa da idade da bacia.

Subseqüentemente, deve ser dada continuidade aos estudos comparativos entre a Formação Camarinha e as ocorrências semelhantes à mesma no Sul e Sudeste do Brasil, visando o estabelecimento ou não de correlações entre si. Estes estudos devem incluir, além das bacias mais 
estudadas como as de Eleutério, Pouso Alegre, Pico de Itapeva, Itajaí e Camaquã, as ocorrências menores tais como os depósitos de Salto de Pirapora, Pirapora do Bom Jesus, Quatis e Samambaia (SP) e Formação Ervalzinho (PR), os quais encontram-se ainda pouco estudados. Nestes estudos comparativos e regionais poderão ser encontradas pistas para o melhor entendimento dessas unidades no contexto geotectônico da Província Mantiqueira. 


\section{REFERÊNCIAS BIBLIOGRÁFICAS}

ADAMS, A.E.; MACKENZIE, W.S.; GUILFORD, C. 1992. Atlante delle rocce sedimentarie al microscopio. Zanichelli, Bologna. 104p.

ALBUQUERQUE, L.F.F.; ARIOLI, E.E; DIAS, A.D.A.; KIRCHNER, C.A. 1971. Geologia das quadriculas de Blumenau e Joinville, SC. Rel. Int. Conv. DNPMCPRM, Porto Alegre (RS). $101 \mathrm{p}$.

ALLEN, P.A. \& ALLEN, J.R. 1990. Basin Analysis: principles and applications. Blackwell Sci. Publ., Oxford. 449p.

ALLEN, P.A. \& HOMEWOOD, P. 1986. Foreland basins. Intern. Assoc. of Sedimentologists Spec. Publ., 8. 443p.

ALLEN, P.A.; HOMEWOOD, P.; WILLIAMS, G.D. 1986. Foreland basins: na introduction. In: ALLEN, P.A. \& HOMEWOOD, P. 1986. Foreland basins. Intern. Assoc. of Sedimentologists Spec. Publ., 8: 3-12.

ALMEIDA, D. del P.M.; ZERFASS, H.; BASEI, M.A.S. 1996. Mineralogia, geoquímica e novas idades para o vulcanismo ácido da Bacia do Camaquã, RS. In: CONGR. BRAS. DE GEOL., 39. Salvador (BA), 1996. Anais... Salvador (BA), SBG 2: 19 21.

ALMEIDA, F.F.M. de. 1949. Novo campo de riolitos e tufos no Sul do Brasil. Mineração e Metalurgia, 14(82): 101-103.

ALMEIDA, F.F.M. de. 1964. Fundamentos geologicos do relevo paulista. Bol. IGG, 41: 167-262.

ALMEIDA, F.F.M. de. 1969. Diferenciação tectônica da Plataforma Brasileira. In: CONG. BRAS. DE GEOL., XXIII. Salvador (BA), 1969. Anais... Salvador (BA), SBG: 2946.

ALMEIDA, F.F.M. de; AMARAL, G.; CORDANI, U.G.; KAWASHITA, K. 1973. The precambrian evolution of the south american cratonic margin south of the Amazon River. In: NAIRN, E.M. \& STEHLI, F.G., eds. 1973. The ocean basins and margins. Plenun l, New York: 411-446.

ALMEIDA, F.F.M. de; HASUI, Y.; BRITO NEVES, B.B. de. 1976. The Upper Precambrian of South America. Bol. IG-USP, 7: 45-80.

ALMEIDA, F.F.M. de; HASUI, Y.; BRITO NEVES, B.B. de; FUCK, R.A. 1977. Províncias estruturais brasileiras. In: SIMP. GEOL. DO NORDESTE, VIII. Campina Grande (PB), 1977. Atas... SBG: 363 391. 
ANADÓN, P.; CABRERA, L.; COLOMBO, F.; MARZO, M.; RIBA, O. 1986. Syntectonic intraformational unconformities in alluvial fan deposits, eastern Ebro Basin margins (NE Spain). In: ALLEN, P.A. \& HOMEWOOD, P. 1986. Foreland basins. Intern. Assoc. of Sedimentologists Spec. Publ., 8: 259-271.

APPI, C.J. \& CRUZ, C.E.S. 1990. Estratigrafia de seqüências na Bacia do Itajaí. In: CONG. BRAS. DE GEOL., 36. Natal (RN), 1990. Anais... Natal (RN), SBG 1: 93106.

APPI, C.J.; CRUZ, C.E.S.; ROSTIROLLA, S.P. 1990. Estratigrafia de seqüências na Bacia do Itajaí. In: REUNIÃO INTENACIONAL DO PROJETO 270 - PICG, III. São Paulo (SP), 1990. Guia da Excursão... São Paulo (SP): 44-53.

APPI, C.J.; CRUZ, C.E.S.; BARROCAS, S.L.; FREITAS, E.L. de. 1987. Modelo deposicional dos turbiditos do Proterozóico Superior do Grupo Itajaí - SC. In: SIMP. SOBRE SISTEMAS DEPOSICIONAIS NO PRE-CAMBRIANO. Ouro Preto (MG), 1987. Atas... Ouro Preto (MG), SBG 6: 31-46.

ASSINE, M.L. 1994. Paleocorrentes e paleogeografia na Bacia do Araripe, nordeste do Brasil. Rev. Bras. Geociênc., 24(4): 223-232.

ASSINE, M.L. 1996. Aspectos da Estratigrafia das Seqüiências Pré-Carboníferas da Bacia do Paraná no Brasil. Tese de Doutoramento IG-USP, São Paulo (SP). 207p.

BALLANCE, P.F. \& READING, H.G., eds. 1980. Sedimentation in oblique-slip mobile zones. Intern. Assoc. of Sedimentologists Spec. Publ., 4. 265p.

BASEI, M.A.S. 1985. O Cinturão Dom Feliciano em Santa Catarina. Tese de Doutoramento IG-USP, São Paulo (SP). 193p.

BASEI, M.A.S. \& BRITO NEVES, B.B. 1992. Características geológicas da transição Proterozóico-Fanerozóico no Brasil. In: GUTIERREZ, J.G.M., SAAVEDRA, J., RÁBANO, I. eds. 1992. Paleozoico Inferior de Ibero-America. Univ. Extremadura, Madrid: 331-342.

BASEI, M.A.S.; CITRONI, S.B.; SIGA Jr., O. 1998 Stratigraphy and age of finiproterozoic basins of Paraná and Santa Catarina States, Southern Brazil. Bol. $I G^{-}$ USP, 29: 195-216.

BASEI, M.A.S.; KAWASHITA, K.; SIGA Jr., O. 1987. Idade, características litoestratigráficas e estruturais do Grupo Itajaí, Santa Catarina. In: SIMP. SULBRAS. DE GEOL., III. Curitiba (PR), 1987. Anais... Curitiba (PR), SBG 1: 93-106.

BASEI, M.A.S.; SIGA Jr., O.; CORDANI, U.G.; SATO, K.; LIMA, P.S. de. 1999. The magmatism of the Itajaí Basin, SC, southern Brazil, and its importance to define the Proterozoic-Phanerozoic limit. In: SIMPOSIO SUDAMERICANO DE GEOLOGIA ISOTOPICA (SSAGI), II. Córdoba, 1999. Actas... 287-290. 
BASEI, M.A.S.; SIGA Jr., O.; REIS NETO, J.M. dos; HARARA, O.M.; PASSARELLI, C.R.; MACHIAVELLI, A. 1997. Geochronological map of the precambrian terrains of Paraná and Santa Catarina states, southern Brazil. In: SOUTH-AMERICAN SYMPOSIUM ON ISOTOPE GEOLOGY (SSAGI), I. Campos do Jordão (SP), 1997. Extended Abstracts... 44-46.

BATOLLA Jr., F.; CARVALHO, M.A.S.; COLANERI, S.; AGUIAR NETO, A. 1977. Projeto Leste do Paraná, Folha Curitiba. Rel. Final Conv. DNPM-BADEP-IGUFP, vol.1, São Paulo (SP). 250p.

BEER, J.A.; ALLMENDIGER, R.N.; FIGUEROA, D.E.; JORDAN, T.E. 1990. Seismic stratigraphy of a neogene piggyback basin, Argentina. AAPG Bull., 74(8): 11831202.

BHATTACHARYA, J.P. \& WALKER, R.G. 1992. Deltas. In: WALKER, R.G. \& JAMES, N.P., eds. 1992. Facies Models: response to sea level change. Geol. Assoc. of Canada, Ontario: 157-177.

BIDDLE, K.T. \& CHRISTIE-BLICK, N., eds. 1985. Strike-slip deformation, basin formation and sedimentation. Soc. of Econ. Paleontologists and Mineralogists Spec.
Publ., 37. 386p.

BIGARELLA, J.J. \& MOUSINHO, M.R. 1965. Significado paleogeográfico e paleoclimático dos depósitos rudáceos. Bol. Paran. Geografia, 16/17: 7-16.

BIGARELLA, J.J. \& SALAMUNI, R. 1956. Estudos preliminares da Série Açungui. V. Estruturas organógenas nos dolomitos da Formação Capiru (Estado do Paraná). Dusenia, 7(6): 317-323.

BIGARELLA, J.J. \& SALAMUNI, R. 1958. Estudos preliminares da Série Açungui. VII. A Formação Votuverava. Bol. Inst. Hist. Nat. Geol., 1: 1-10.

BISSI Jr., C.; PORTELLA, M.G.; COSTA, S.O. 1990. Relatório do mapeamento geológico a sudeste de Geada, Campo Largo. Rel. Grad. UFPR, Curitiba (PR). 66p.

BLAIR, T.C. 1987. Sedimentary processes, vertical stratification sequences and geomorphology of the Roaring River alluvial fan, Rocky Mountain National Park, Colorado. Jour. of Sedim. Petrol., 57(1): 1-18.

BLAIR, T.C. \& McPHERSON, J.G. 1992. The Trollheim alluvial fan and facies model revisited. Geol. Soc. of America Bull., 104 (6): 762-769.

BLAIR, T.C. \& McPHERSON, J.G. 1994a. Alluvial fan processes and forms. In: ABRAHAMS, A.D. \& PARSONS, A.J., eds. 1994. Geomorphology of desert environments. Champan \& Hall, London: 354-402. 
BLAIR, T.C. \& McPHERSON, J.G. 1994b. Alluvial fans and their natural distinction from rivers based on morphology, hydraulic processes, sedimentary processes, and facies assemblages. Jour. of Sedim. Research, A64(3): 450-489.

BOGGS Jr., S. 1995. Principles of sedimentology and stratigraphy. Prentice Hall, New Jersey. 774p.

BONACIM, E.A.; MORO, R. de P.X.; SOARES, P.C. 1994. Tectônica da Bacia ordoviciana de Castro - Paraná. Bol. Paran. Geociênc., 42: 59-72.

BONHOMME, M.E. \& RIBEIRO, M.J. 1983. Datações K-Ar das argilas associadas a mineralizações de cobre da Mina Camaquã e de suas encaixantes. In: SIMP. SULBRAS. DE GEOL., I. Porto Alegre (RS), 1983. Atas... Porto Alegre (RS), SBG 1:
82-88.

BULL, W.B. 1972. Recognition of alluvial-fan deposits in the stratigraphic record. In: RIGBY, J.K. \& HAMBLIN, W.K., eds. 1972. Recognition of ancient sedimentary environments. Soc. of Econ. Paleontologists and Mineralogists Spec. Publ., 16: 63-
83 . BURNHAM, C.W. 1962. Facies and types of hydrothermal alteration. Econ. Geol., 57 :
$768-784$.

BUSBY, C.J. \& INGERSOLL, R.V., eds. 1995. Tectonics of sedimentary basins. Blackwell Sci. Inc., Cambridge. 579p.

CAMPANHA, G.A.C. \& TEIXEIRA, A.L. 1986. Nota sobre a ocorrência de um novo depósito molássico de possível idade eopaleozóica no Estado de São Paulo: Formação Quatis. An. Acad. Bras. Ciênc., 58(4): 595.

CAPUANO, N. 1993. Tectonic generation of lowstand turbidite units in a foreland basin, Marchean Apennines, Italy. In: FROSTICK, L.E. \& STEEL, R.J., eds. 1993. Tectonic controls and signatures in sedimentary successions. Intern. Assoc. of
Sedimentologists Spec. Publ., 20: 291-299.

CARVALHO, P.F. 1932. Reconhecimento geológico no Estado do Rio Grande do Sul. Bol. Serv. Geol. Mineral. do Brasil, 72: 1-72.

CARVALHO, P.F. \& PINTO, E.A. 1937. Reconhecimento geológico na Série Açungui. Bol. Div. Geol. Min. DNPM, 71.29p.

CARVALHO, P.F. \& PINTO, E.A. 1938. Reconhecimento geológico no Estado de Santa Catarina. Bol. Serv. Geol. Mineral. do Brasil, $92.31 \mathrm{p}$.

CASTRO, N.A. de. 1993. Relatório das atividades realizadas na Bacia Guaratubinha-PR. Rel. Inic. Cient. CNPq, Curitiba (PR). 89p. 
CAVALCANTE, J.C.; CUNHA, H.C.S.; CHIEREGATTI, L.A.; KAEFER, L.Q.; ROCHA, J.M.; DAITX, E.C.; COUTINHO, M.G.N.; YAMAMOTO, K.; DRUMOND, J.B.V.; ROSA, D.B.; RAMALHO, R. 1979. Projeto Sapucaí. DNPM, Série Geologia n-4, Seção Geologia Básica n².299p.

CHRISTIE-BLICK, N. \& BIDDLE, K.T. 1985. Deformation and basin formation along strike-slip faults. In: BIDDLE, K.T. \& CHRISTIE-BLICK, N., eds. 1985. Strikeslip deformation, basin formation and sedimentation. Soc. of Econ. Paleontologists and Mineralogists Spec. Publ., 37: 1-34.

CIGUEL, J.H.G. \& GODOY, H. 1985. Relatório da folha geológica de Camarinha - parcial leste Cerro do Purunã. Rel. Grad. UFPR, Curitiba (PR). $111 \mathrm{p}$.

CIGUEL, J.H.G. \& GÓIS, J.R. de. 1989. O Paleozóico Inferior das regiões sul-sudeste do Brasil. Correlación Geologica, 5: 165-178.

CIGUEL, J.H.G.; GÓIS, J.R. de; ACEÑOLAZA, F.G. 1992. Ocorrência de Icnofósseis em depósitos molássicos da Formação Camarinha (Neoproterozóico III-Cambriano Inferior), no Estado do Paraná, Brasil. Correlación Geologica, 9: 157 158.

CIPOLLARI, P. \& COSENTINO, D. 1993. Le "Arenarie di Torrice": un deposito di bacino di piggyback del Messiniano nell'Appennino Centrale. Bol. Soc. Geol. It.,
113: 465 481.

CITRONI, S.B. 1993. Ambientes deposicionais e significado geotectônico da sedimentação do Grupo Itajaí-SC. Dissert. Mestrado IG-USP, São Paulo (SP). 145p.

CITRONI, S.B. 1998. Bacia de Campo Alegre-SC: aspectos petrológicos, estratigráficos e caracterização geotectônica. Tese de Doutoramento $I G$-USP, São Paulo (SP). 184p.

CITRONI, S.B.; BASEI, M.A.S.; SATO, K.; SIGA Jr., O. 1999. Petrogenesis of the Campo Alegre Basin magmatism based on geochemical and isotopic data. In: SIMPOSIO SUDAMERICANO DE GEOLOGIA ISOTOPICA (SSAGI), II. Córdoba, 1999.
Actas... 174-177.

COLELLA, A. \& PRIOR, D.B., eds. 1990. Coarse-grained deltas. Intern. Assoc. of Sedimentologists Spec. Publ., 10.357p.

COLEMAN, J.M. \& PRIOR, D.B. 1982. Deltaic environments of deposition. In: SCHOLLE, P.A. \& SPEARING, D., eds. 1982. Sandstone depositional environments. AAPG Memoir, 31: 139-178.

COLLINSON, J.D. 1996. Alluvial Sediments. In: READING, H.G., ed. 1996. Sedimentary Environments: processes, facies and stratigraphy, 3rd ed. Blackwell Sci. Ltd.,
Cambridge: $37-82$. 
COLLINSON, J.D. \& THOMPSON, J.D. 1989. Sedimentary structures. George Allen \& Unwin, London. 194p.

COMPTON, R.R. 1985. Geology in the field. John Wiley \& Sons, New York. 398p.

CORDANI, U.G.; BASEI, M.A.S.; SIGA Jr., O.S.; CITRONI, S.B. 1999. U-Pb Shrimp ages for Late Proterozoic acid volcanics of southern Brazil: tectonic implications. In: GSA ANNUAL MEETING. Denver, 1999. Geological Society of America Abstracts with Programs, 31(7): A-108.

CPRM, 1997. Símbolos para mapas geológicos. Instrução Técnica 03. In: Manual técnico de Geologia. DIGEOB-CPRM, Salvador (BA). 22p.

CRÓSTA, A. 1993. Processamento digital de imagens de sensoriamento remoto. $E d$. Unicamp, Campinas (SP). 170p.

CROWELL, J.C. 1974a. Sedimentation along the San Andreas Fault, California. In: DOTT Jr., R.H. \& SHAVER, R.H., eds. 1974. Modern and ancient geosynclinal sedimentation. Soc. of Econ. Paleontologists and Mineralogists Spec. Publ, 19: 292303.

CROWELL, J.C. 1974b. Origin of Late Cenozoic basins in southern California. In: DICKINSIN, W.R., ed. 1974. Tectonics and sedimentation. Soc. of Econ. Paleontologists and Mineralogists Spec. Publ, 22: 190-204.

DAITX, E.C. \& CARVALHO, M.S. 1981. Projeto Geoquímica na área de GuaratubinhaPiên. Rel. Final Conv. DNPM-CPRM, vol.1. 184p.

DAVIS, G.H. 1984. Structural Geology of rocks and regions. John Wiley \& Sons, Singapore. 492p.

DERBY, O.A. 1878. A geologia da região diamantífera da Província do Paraná. Arch. Mus. Nac., 3: 89-98.

DIAS, M.V.F. \& SALAZAR Jr., O. 1987. Geologia da Seqüência Antinha, Grupo Açungui (PR). In: SIMP. SUL-BRAS. DE GEOL., III. Curitiba (PR), 1987. Anais... Curitiba (PR), SBG 1: 263-279.

DICKINSON, W.R. 1985. Interpreting provenance relations from detrital modes of sandstones. In: ZUFFA, G.G., ed. 1985. Provenance of arenites. D. Reidel Publishing Co.: 333-361

DICKINSON, W.R. 1988. Provenance and sediment dispersal in relation to paleotectonics and paleogeography of sedimentary basins. In: KLEINSPEHN, K.L. \& PAOLA, C., eds. 1988. New perspectives in basin analysis. Springer-Verlag, New York: 3-25.

DICKINSON, W.R.; BEARD, L.S.; BRAKENRIDGE, G.R.; ERJAVEC, J.L.; 
FERGUSON, R.C.; INMAN, K.F.; KNEPP, R.A.; LINDBERG, F.A.;RYBERG, P.T. 1983. Provenance of North American Phanerozoic sandstones in relation to tectonic setting. Geol. Soc. of America Bull., 94: 222-235.

DORADO, A.C. 1989. Petrografia basica: texturas, clasificación y nomenclatura de rocas. Paraninfo, Madrid. 143p.

DOTT Jr., R.H. 1964. Wacke, graywacke and matrix - what approach to immature sandstone classification? Jour. of Sedim. Petrol., 34 (3): 625-632.

DUTRA, E.B. 1926. Reconhecimento topográfico e geológico no Estado de Santa Catarina. Bol. DNPM, 21: 31-56.

EBERT, H. 1968. Ocorrência de fácies granulítica no sul de Minas e em áreas adjacentes, em dependência da estrutura orogênica: hipótese sobre sua origem. An. Acad. Bras. Ciênc., 40 (supl.): 215-229.

EBERT, H. 1971a. Observações sobre as litologias e subdivisão do Grupo Setuva no Estado do Paraná, com sugestões à tectônica geral do geossinclíneo Açungui. In: CONGR. BRAS. DE GEOL., XXV. São Paulo (SP), 1971. Anais... São Paulo (SP), SBG 1: 131-165.

EBERT, H. 1971b. Os Paraibides entre São João del Rei, Minas Gerais e Itapira, São Paulo e a bifurcação entre Paraibides e Araxaídes. In: CONGR. BRAS. DE GEOL., XXV. São Paulo (SP), 1971. Res. Coms... São Paulo (SP), SBG. Bol. Esp.1: 177-178.

EBERT, H. 1971c. O Grupo Guaratubinha no norte do Estado de Santa Catarina. In: CONGR. BRAS. DE GEOL., XXV. São Paulo (SP), 1971. Anais... São Paulo (SP), SBG 1: $147-165$.

EINSELE, G. 1992. Sedimentary Basins: evolution, facies and sediment budget. SpringerVerlag, Berlin-Heidelberg. $628 \mathrm{p}$.

ESLINGER, E. \& PEVEAR, D. 1988. Clay minerals for petroleum geologists and engineers. Soc. of Econ. Paleontologists and Mineralogists Short Course Notes, 22. $418 \mathrm{p}$.

ETHRIDGE, F.G. \& FLORES, R.M., eds. 1983. Recent and ancient nonmarine depositional environments: models for exploration. Soc. of Econ. Paleontologists and Mineralogists Spec. Publ, 31.349p.

FAMBRINI, G.L. 1998. O Grupo Camaquã (transição Proterozóico-Fanerozóico) na região das Minas do Camaquã, RS: análise estratigráfica de fácies, proveniência e paleocorrentes. Dissert. Mestrado IG-USP, São Paulo (SP). 182p.

FASSBINDER, E. 1990. Análise Estrutural da Falha da Lancinha, Estado do Paraná. Dissert. Mestrado IG-USP, São Paulo (SP). 165p. 
FASSBINDER, E. 1996. A Unidade Água Clara no contexto do Grupo Açungui: um modelo transpressivo de colisão oblíqua no Neoproterozóico paranaense. Tese de Doutoramento IG-USP, São Paulo (SP). 207p.

FASSBINDER, E; SADOWSKI, G.R.; FIORI, A.P. 1994. Modelo de Riedel aplicado ao Lineamento da Lancinha, no Estado do Paraná. Bol. Paran. Geociênc., 42: 173-184.

FIORI, A.P., coord. 1984. Lineamentos tectônicos e possíveis mineralizações associadas no Pré-Cambriano paranaense. Rel. Conv. UFPR-MINEROPAR, vol.1, Curitiba (PR). $261 \mathrm{p}$.

FIORI, A.P. 1985a. A Falha da Lancinha no Pré-Cambriano paranaense: reflexo de uma falha profunda? Bol. Paran. Geociênc., 36: 6-14.

FIORI, A.P. 1985b. Avaliação preliminar do deslocamento dúctil das falhas da Lancinha e de Morro Agudo no Estado do Paraná. Bol. Paran. Geociênc., 36: 15-30.

FIORI, A.P., coord. 1985c. Estudos geológicos integrados do Pré-Cambriano paranaense. Rel. Conv. UFPR-MINEROPAR, Curitiba (PR). 192p.

FIORI, A.P. 1985d. Aplicação do modelo de cisalhamento simples na análise da deformação dúctil de alguns granitos paranaenses. Bol. Paran. Geociênc., 36: 3140 .

FIORI, A.P. 1990. Tectônica e Estratigrafia do Grupo Açungui a norte de Curitiba. Tese de Livre-Docência IG-USP, São Paulo (SP). 261p.

FIORI, A.P. 1997. Introdução à análise da deformação. Ed. UFPR, Curitiba (PR). 249p.

FIORI, A.P.; FASSBINDER, E; GÓIS, J.R. de; FUMAGALLI, C.E. $1987 \mathrm{a}$. Compartimentação tectônica do Grupo Açungui a norte de Curitiba. In: SIMP. SUL-BRAS. DE GEOL., III. Curitiba (PR), 1987. Anais... Curitiba (PR), SBG 1: 183-196.

FIORI, A.P.; FUMAGALLI, C.E.; GÓIS, J.R. de; SALAMUNI, E. 1987b. As principais estruturas dobradas do Grupo Açungui na região de Rio Branco-Bocaiúva do Sul. In: SIMP. SUL-BRAS. DE GEOL., III. Curitiba (PR), 1987. Anais... Curitiba (PR), SBG 1: 281-301.

FIORI, A.P.; SALAMUNI, E.; FASSBINDER, E. 1987c. Geologia da região de Bateias Bocaiúva do Sul. In: SIMP. SUL-BRAS. DE GEOL., III. Curitiba (PR), 1987. Anais... Curitiba (PR), SBG 2: 773-787.

FIORI, A.P.; WERNICK, E.; BETTENCOURT, J.S. 1978. Evolução policíclica na região Nordeste do Estado de São Paulo e áreas vizinhas do Estado de Minas Gerais. In: CONGR. BRAS. DE GEOL., XXX. Recife (PE), 1978. Anais... Recife (PE), SBG 


\section{1: $303-320$.}

FRAGOSO CÉSAR, A.R.S. 1991. Tectônica de Placas no Ciclo Brasiliano: as orogenias dos cinturões Dom Feliciano e Ribeira no Rio Grande do Sul. Tese de Doutoramento IG-USP, São Paulo (SP). 366p.

FRAGOSO CÉSAR, A.R.S.; FACCINI, U.F.; PAIM, P.S.G.; LAVINA, E.L.; ALTAMIRANO, J.A.F. 1985. Revisão na estratigrafia das molassas do Ciclo Brasiliano no Rio Grande do Sul. In: SIMP. SUL-BRAS. DE GEOL., II. Florianópolis (SC), 1985. Anais... Florianópolis (SC), SBG: 477-491.

FRAGOSO CÉSAR, A.R.S.; LAVINA, E.L.; PAIM, P.S.G.; FACCINI, U.F. 1984. A Antefossa Molássica do Cinturão Dom Feliciano no Escudo do Rio Grande do Sul. In: CONGR. BRAS. DE GEOL., XXXIII. Rio de Janeiro (RJ), 1984. Anais... Rio de Janeiro (RJ), SBG 7: 3272-3283.

FRAGOSO CÉSAR, A.R.S.; SILVA FILHO, W.F.; SAYEG, H.S.; FAMBRINI, G.L.; SAES, G.S.; MACHADO, P.; RIBEIRO DE ALMEIDA, T.I. 1998. O Grupo Guaritas (Eopaleozóico do Rio Grande do Sul): testemunho do primeiro evento deposicional da Bacia do Paraná? An. Acad. Bras. Ciênc., 70(3): 690.

FRAGOSO CÉSAR, A.R.S.; WERNICK, E; SOLIANI Jr., E. 1982a. Associações petrotectônicas do Cinturão Dom Feliciano (SE da Plataforma Sul-Americana). In: CONGR. BRAS. DE GEOL., XXXII. Salvador (BA), 1982. Anais... Salvador (BA), SBG 1: 1-12.

FRAGOSO CÉSAR, A.R.S.; WERNICK, E.; SOLIANI Jr., E. 1982b. Evolução Geotectônica - uma contribuição através da aplicação do modelo da Tectônica de Placas. In: CONGR. BRAS. DE GEOL., XXXII. Salvador (BA), 1982. Anais... Salvador (BA), SBG 1: 13-23.

FREITAS, R.O. de. 1945. O Conglomerado do Baú (Série Itajaí-Santa Catarina). Bol. FFCL-USP, 1(Geol.2): 31-113.

FRITZ, W.J. \& MOORE, J.N. 1988. Basics of Physical Stratigraphy and Sedimentology. John Wiley \& Sons, New York. 371p.

FRITZSONS Jr., O.; PIEKARZ, G.F.; FALCADE, D. 1982. Geologia e potencial econômico do Grupo Setuva (PR). In: CONGR. BRAS. DE GEOL., XXXII. Salvador (BA), 1982. Anais... Salvador (BA), SBG 3: 991-1001.

FROSTICK, L.E. \& STEEL, R.J., eds. 1993. Tectonic controls and signatures in sedimentary successions. Intern. Assoc. of Sedimentologists Spec. Publ., 20. 520p.

FUCK, R.A.1966. Nota explicativa da Folha Geológica de Quero-Quero. Bol. UFPR, Inst. Geol., Geol. 19. 21 p. 
FUCK, R.A.; BIGARELLA, J.J.; SALAMUNI, R.; ALESSI, A.H. 1965. Folha Geológica de Quero-Quero. Com. da Carta Geológica do Paraná. Esc. 1:50.000.

FUCK, R.A.; MARINI, O.J.; TREIN, E. 1967a. Contribuição ao estudo das rochas graníticas do Estado do Paraná. Bol. Paran. Geociênc., 23-25: 183-219.

FUCK, R.A.; MARINI, O.J.; TREIN, E. 1967b. A Formação Guaratubinha. Bol. Paran. Geociênc., 23-25: 237-255.

FUCK, R.A.; TREIN, E.; MARINI, O.J. 1971. Geologia do Leste Paranaense. In: CONGR. BRAS. DE GEOL., XXV. São Paulo (SP), 1971. Anais... São Paulo (SP), SBG 1: $121-130$.

GALLOWAY, W.E. \& HOBDAY, D.K. 1983. Terrigenous Clastic Depositional Systems. Springer-Verlag, New York. 423p.

GHIBAUDO, G. 1992. Subaqueous sediment gravity flow deposits: practical to their field description and classification. Sedimentology, 39(3): 423-454.

GIMENEZ FILHO, A. 1993. Evolução do Complexo Granítico Três Córregos a noroeste de Apiaí - SP. Dissert. Mestrado IG-USP, São Paulo (SP). $118 \mathrm{p}$.

GLOPPEN, T.G. \& STEEL, R.J. 1981. The deposits, internal structure and geometry in six alluvial fan-fan delta bodies (Devonian-Norway) - a study in the significance of bedding sequence in conglomerates. In: ETHRIDGE, F.G. \& FLORES, R.M., eds. 1983. Recent and ancient nonmarine depositional environments: models for exploration. Soc. of Econ. Paleontologists and Mineralogists Spec. Publ, 31: 49-69.

GÓIS, J.R. de. 1990. A Formação Camarinha. In: REUNIÃO INTENACIONAL DO PROJETO 270 - PICG, III. São Paulo (SP), 1990. Guia da Excursão... São Paulo (SP): 24-29.

GÓIS, J.R. \& HORSTMANN, L.H. 1984. Relatório da folha geológica Retiro Grande/parcial oeste Bateias. Rel. Grad. UFPR, Curitiba (PR). 111p.

GOÑI, J.C.; GOSO, H.; ISSLER, R.S. 1962. Estratigrafia e geologia econômica do PréCambriano e Eo-Paleozóico uruguaio e sul-rio-grandense. Avulso da Escola de Geologia UFRGS, vol.3, Porto Alegre (RS): 1-105.

HACHIRO, J. \& SANTORO, E. 1996. Uma provável bacia terrígeno-carbonática de idade neoproterozóico-eopaleozóica, em Cajamar (SP). An. Acad. Bras. Ciênc., 68(4): 601.

HACKSPACHER, P.C.; DANTAS, E.L.; SPOLADORE, A.; FETTER, A. 1999. Evolução da Faixa Ribeira, na região de Apiaí, Sudeste do Brasil: geocronologia U-Pb em zircão de rochas metabásicas e granito. In: SIMP. GEOL. DO SUDESTE, VI. São Pedro (SP), 1999. Bol. Resumos... SBG: 12. 
HAMA, M. \& CUNHA, H.C.S. 1977. Consideração sobre a idade da Formação Pouso Alegre e dos granitos pós cambrianos na região sul de Minas Gerais e nordeste do Estado de São Paulo. In: SIMP. REG. DE GEOL., I. São Paulo (SP), 1977. Atas... São Paulo (SP), SBG 1: 48-58.

HARARA, O.M.; BASEI, M.A.S.; SIGA Jr., O. 1997. Geochronological and geochemical data on the transition zone between Luis Alves and Atuba complexes, south Brazil. In: SOUTH-AMERICAN SYMPOSIUM ON ISOTOPE GEOLOGY (SSAGI), I. Campos do Jordão (SP), 1997. Extended Abstracts... 134-136.

HASENACK, H. \& WEBER, E., eds. 1998. Idrisi for Windows, versão 2: Manual do usuário - Introdução e exercícios tutoriais. Centro de recursos Idrisi, UFRGS, Porto Alegre (RS). 70p.

HASUI, Y.; ALMEIDA, F.F.M.; MARTINI, S.L.; MARTINS, F.A.G. 1982. Modelos metalogenéticos e possibilidade de mineralização no Pré-Cambriano do estado de São Paulo (Relatório Final). Rel. IPT ñ 17.818, SICCT/PRÓ-MINÉRIO, São Paulo (SP). 164p.

HASUI, Y.; CARNEIRO, C. dal R.; COIMBRA, A.M. 1975. The Ribeira Folded Belt. Rev. Bras. Geociênc., 5(4): 257-266.

HEMLEY, J. \& JONES, W.R. 1964. Chemical aspects of hydrothermal alteration with emphasys on hydrogen metasomatism. Econ. Geol., 59: 538-569.

IBGE. 1998. Manual técnico de Geologia. In: Manuais Técnicos em Geociências, 6. 306p.

INGERSOLL, R.V. \& BUSBY, C.J. 1995. Tectonics of sedimentary basins. In: BUSBY, C.J. \& INGERSOLL, R.V., eds. 1995. Tectonics of sedimentary basins. Blackwell Sci. Inc., Cambridge: 1-51.

JORDAN, T.E. 1995, Retroarc foreland and related basins. In: BUSBY, C.J. \& INGERSOLL, R.V., eds. 1995. Tectonics of sedimentary basins. Blackwell Sci. Inc., Cambridge: 331-362.

JULIANI, C.; RICCOMINI, C.; BARROS, E.J.; BATISTUCCI, N.L.N. 1990. Proterozoic storm-dominated sedimentation in the Pico de Itapeva Formation (São Paulo State, Brazil). An. Acad. Bras. Ciênc., 62: 105.

KATBEH, A.; PALUDO, M.A.; ARARA, O.M. 1989. Relatório do mapa geológico da região de Povinho de São João (Campo Largo - PR). Rel. Grad. UFPR, Curitiba (PR). 140p.

KERSEY, D.G. \& HSÜ, K.J. 1976. Energy relations of density-current flows: an experimental investigation. Sedimentology, 23: 761-789.

KINGSTON, D.R.; DISHROON, C.P.; WILLIAMS, P.A. 1983. Global Basin 
Classification System. AAPG Bull., 67(12): 2175-2193.

KLEINSPEHN, K.L. \& PAOLA, C., eds. 1988. New perspectives in basin analysis. Springer-Verlag, New York. 453p.

KLEINSPEHN, K.L.; STEEL, R.J.; JOHANNESSEN, E.; NETLAND, A. 1984. Conglomeratic fan-delta sequences, Late Carboniferous-Early Permian, Western Spitsbergen. In: KOSTER, E.M. \& STEEL, R., eds. 1984. Sedimentology of gravels and conglomerates. Can. Soc. of Petroleum Geologists Memoir, 10: 279-294.

KOPS, P.T. 1994. Geologia das formações Antinha, Votuverava e Água Clara a sudeste do Complexo Granítico Três Córregos, estado do Paraná. Dissert. Mestrado IGCEUNESP, Rio Claro (SP). 132p.

KOSTER, E.M. \& STEEL, R., eds. 1984. Sedimentology of gravels and conglomerates. Can. Soc. of Petroleum Geologists Memoir, $10.441 \mathrm{p}$.

KREBS, A.S.J.; CALDASSO, A.L. da S.; LOPES, R. da C. 1988. Interpretação preliminar da seqüência deposicional da Bacia do Itajaí na área da Folha Botuverá, Santa Catarina. In: CONG. BRAS. DE GEOL., 35. Belém (PA), 1988. Anais... Belém
(PA), SBG 2: 592-605.

LAHEE, F.H. 1952. Field geology. McGraw Hill Book Co., Inc., New York. 883p.

LEINZ, V. 1936. Os porphyros de Castro. An. Acad. Bras. Ciênc., 8(4): 305-311.

LEINZ, V. 1939. Problema geológico do Post-Arqueano no Rio Grande do Sul. Mineração
e Metalurgia, 4(22): 203-206.

LEINZ, V.; BARBOSA, A.F.; TEIXEIRA, G.A. 1941. Mapa Geológico Caçapava-Lavras. Bol. Div. Prod. Min. da Secret. Agric., Ind. e Commercio, vol.1, Porto Alegre (RS):
1-39.

LEONARDOS Jr., O.H.; DUNHAM, A.C.; PIRES, F.R.M.; FORMAN, J.M.A. 1971. Nota sobre a Formação Pouso Alegre. An. Acad. Bras. Ciênc., 43: 131-143.

LICCARDO, A.; SORIA, E.L.; CORDEIRO, T.B. 1990. Informações e interpretações complementares a respeito do mapa geológico estrutural da região do Morro Serrinha nordeste de Itambé. Rel. Grad. UFPR, Curitiba (PR). 144p.

LOWE, D.R. 1982. Sediment gravity flows: II. Depositional models with special reference to the deposits of high-density turbidity currents. Jour. of Sedim. Petrol., 52(1):
279-297.

MAACK, R.A. 1947. Breves notícias sobre a geologia dos estados do Paraná e Santa Catarina. Arqs. Biol. Tecn., 2: 63-154. 
MACEDO, M.H.F.; BASEI, M.A.S.; BONHOMME, M.G.; KAWASHITA, K. 1984. Dados geocronológicos referentes às rochas metassedimentares do Grupo Itajai (SC). Rev. Bras. Geociênc., 14(1): 30-34.

MACHADO, R. \& SAYEG, H.S. 1992. Aplicação da análise geométrica e cinemática nos falhamentos que condicionaram a bacia molássica do Arroio Boici, RS. In: WORKSHOP SOBRE AS BACIAS MOLÁSSICAS BRASILIANAS, I. São Leopoldo (RS), 1992. Bol. Res. Expandidos... São Leopoldo (RS), SBG/UNISINOS: 73-76.

MANN, P.; HEMPTON, M.R.; BRADLEY, D.C.; BURKE, K. 1983. Development of pullapart basins. Jour. Of Geology, 91: 529-554.

MARINI, O.J. 1970. Geologia da Folha de Rio Branco do Sul. Tese de Doutoramento Fac. Filos., Ciênc. e Let. de Rio Claro, Rio Claro (SP). 190p.

MARINI, O.J.; TREIN, E.; FUCK, R.A. 1967. O Grupo Açungui no Estado do Paraná. Bol. Paran. Geociênc., 23-25: 43-104.

MARZO, M. \& ANADÓN, P. 1988. Anatomy of a conglomeratic fan-delta complex: the Eocene Montserrat Conglomerate, Ebro Basin, Northeastern Spain. In: NEMEC, W. \& STEEL, R.J., eds. 1988. Fan deltas: sedimentology and tectonic settings. Blackie and Son, Glasgow: 318-340.

MARZO, M. \& PUIGDEFÁBREGAS, C. 1993. Alluvial sedimentation. Intern. Assoc. of Sedimentologists Spec. Publ., 17. 539p.

MASSARI, F. \& COLELLA, A. 1988. Evolution and types of fan-delta systems in some major tectonic settings. In: NEMEC, W. \& STEEL, R.J., eds. 1988. Fan deltas: sedimentology and tectonic settings. Blackie and Son, Glasgow: 103-122.

McPHERSON, J.G.; SHANMUGAM, G.; MOIOLA, R.J. 1987. Fan deltas and braid deltas: varieties of coarse-grained deltas. Geol. Soc. of America Bull., 99: 331-340.

McPHERSON, J.G.; SHANMUGAM, G.; MOIOLA, R.J. 1988. Fan deltas and braid deltas: conceptual problems. In: NEMEC, W. \& STEEL, R.J., eds. 1988. Fan deltas: sedimentology and tectonic settings. Blackie and Son, Glasgow: 14-22.

MENDONÇA FILHO, J.G.; RODRIGUES, L.P.; OLIVEIRA, M.L.P.C. 1990. Informações e interpretações complementares a respeito do mapa geológico da região de Retiro Grande. Rel. Grad. UFPR, Curitiba (PR). $68 \mathrm{p}$.

MEYER, C. \& HEMLEY, J.J. 1967. Wall rock alteration. In: BARNES, H.L., ed. 1967. Geochemistry of hydrothermal ore deposits. Holt Rinehart \& Winston, New York: $166-235$.

MIALL, A.D. 1977. A review of the braided-river depositional environment. Earth Sci. 
Reviews, 13: 1-62

MIALL, A.D., ed. 1978a. Fluvial Sedimentology. Can. Soc. of Petroleum Geologists Memoir, 5. 859p.

MIALL, A.D. 1978b. Lithofacies types and vertical profile models in braided river deposits: a summary. In: MIALL, A.D., ed. 1978a. Fluvial Sedimentology. Can. Soc. of Petroleum Geologists Memoir, 5: 597-604.

MIALL, A.D. 1879c. Tectonic setting and syndepositional deformation of molasse and other nonmarine-paralic sdimentary basins. Can. Jour. Of Earth Sciences, 15: 16131632.

MIALL, A.D. 1990. Principles of Sedimentary Basin Analysis, 2nd ed. Springer-Verlag, New York. 668p.

MIALL, A.D. 1992. Alluvial deposits. In: WALKER, R.G. \& JAMES, N.P., eds. 1992. Facies Models: response to sea level change. Geol. Assoc. of Canada, Ontario: 119. 142.

MIALL, A.D. 1995. Collision-related foreland basins. In: BUSBY, C.J. \& INGERSOLL, R.V., eds. 1995. Tectonics of sedimentary basins. Blackwell Sci. Inc., Cambridge: 393-424.

MITCHELL, A.H.G. \& READING, H.G. 1986. Sedimentation and tectonics. In: READING, H.G., ed. 1986. Sedimentary environments and facies. Blackwell Sci. Publ., Oxford: 471-519.

MORITZ JR., A.R. \& FIORI, A.P. 1987. Análise de seixos deformados da Formação Camarinha. In: SIMP. SUL-BRAS. DE GEOL., III. Curitiba (PR), 1987. Anais... Curitiba (PR), SBG 1: 107-121.

MORO, R. de P.X. 1993. A bacia ordoviciana do Grupo Castro - PR. Dissert. Mestrado IGCE-UNESP, Rio Claro (SP). 157p.

MORO, R. de P.X.; BONACIM, E.A.; SOARES, P.C. 1993. Grupo Castro: conteúdo de uma bacia molássica pós-orogênica no Cambro-ordoviciano paranaense. Acta Geologica Leopoldensia, XVI(37): 119-134.

MORO, R. de P.X.; BONACIM, E.A.; SOARES, P.C. 1994. Geologia da Bacia de Castro PR. Bol. Paran. Geocienc., 42: 43-58

MURATORI, A. 1966. Nota explicativa da Folha Geológica de Campo Largo. Bol. UFPR, Inst. Geol., Geol. 21. 29p.

MURATORI, A.; FUCK, R.A.; BIGARELLA, J.J. 1967. Contribuição ao estudo da 
Formação Camarinha. Bol. Paran. Geociênc., 23-25: 221-235.

MURATORI, A.; FUCK, R.A.; BIGARELLA, J.J.; SALAMUNI, R.; PALKA, J.; LOPES, J.A.; ALESSI, A.H. 1965. Folha Geológica de Campo Largo. Com. da Carta Geológica do Paraná. Esc. 1:50.000.

MUTTI, E. \& RICCI-LUCCHI, F. 1978. Turbidites of the northern Apennines: introduction to facies analysis. Intern. Geol. Review, 20(2): 125-166.

NEIVA, J.J.R. \& TIBINKA, S.M. 1989. Relatório do mapa geológico da região de Itambezinho - município de Campo Largo - PR. Escala 1:10.000. Rel. Grad. UFPR, Curitiba (PR). $161 \mathrm{p}$.

NEMEC, W. \& STEEL, R.J. 1984. Alluvial and coastal conglomerates: their significant features and some comments on gravelly mas-flow deposits. In: KOSTER, E.M. \& STEEL, R., eds. 1984. Sedimentology of gravels and conglomerates. Can. Soc. of Petroleum Geologists Memoir, 10: 1-31.

NEMEC, W. \& STEEL, R.J., eds. 1988. Fan deltas: sedimentology and tectonic settings. Blackie and Son, Glasgow. 444p.

NETTO, R.G.; PAIM, P.S.G.; ROSA, C.L.M. 1992. Registro preliminar da ocorrência de traços fósseis em sedimentos das bacias do Camaquã e Santa Bárbara. In: WORKSHOP SOBRE AS BACIAS MOLÁSSICAS BRASILIANAS, I. São Leopoldo (RS), 1992. Bol. Res. Expandidos... São Leopoldo (RS), SBG/UNISINOS: 90-96.

NILSEN, T.H. 1982. Alluvial fan deposits. In: SCHOLLE, P.A. \& SPEARING, D., eds. 1982. Sandstone depositional environments. AAPG Memoir, 31: 49-86.

NILSEN, T.H. \& SYLVESTER, A.G. 1995. Strike-slip basins. In: BUSBY, C.J. \& INGERSOLL, R.V., eds. 1995. Tectonics of sedimentary basins. Blackwell Sci. Inc., Cambridge: $425-457$.

OLIVEIRA, E.I. \& LEONARDOS, O.H. 1943. Geologia do Brasil. Minist. Agric., Ser. Didát, vol.2, Rio de Janeiro. 782p.

OLIVEIRA, E.P. 1927. Geologia e Recursos Minerais do Estado do Paraná. Serv. Geol. Mineral. do Brasil, Monografia 6, Rio de Janeiro (RJ). 178p.

OLIVEIRA, M.J.R. 1991.Análise do comportamento da Zona de Falha Cubatão-Lancinha na Bacia do Paraná. Dissert. Mestrado UFOP, Ouro Preto (MG). 144p.

OLIVEIRA, J.M.M.T. \& FERNANDES, L.A.D. 1991. Estágios finais da evolução do Cinturão Dom Feliciano: tectônica e sedimentação da Formação Arroio dos Nobres. In: SIMP. NAC. DE ESTUDOS TECTÔNICOS, 3. Rio Claro (SP), 1991. Bol. Res. Extensos. Rio Claro (SP), SBG: 58-59. 
ORI, G.G. \& FRIEND, P.F. 1984. Sedimentary basins formed and carried piggyback on active thrust sheets. Geology, 12: 475-478.

PAIM, P.S.G. 1995. Alluvial palaeogeography of the Guaritas depositional sequence of Southern Brazil. In: PLINT, A.G., ed. 1995. Sedimentary facies analysis. Intern. Assoc. of Sedimentologists Spec. Publ., 22: 3-16.

PAIM, P.S.G.; FACCINI, U.F.; NETTO, R.G.; NOWATZKI, C.H. 1992. Estratigrafia de sequêencias e sistemas deposicionais das bacias do Camaquã e Santa Bárbara, Eopaleozóico do RS (Brasil). Correlación Geologica, 9: 41-45.

PAIM, P.S.G.; LOPES, R.C.; CHEMALE Jr., F. 1995. Aloestratigrafia, sistemas deposicionais e evolução paleogeográfica da Bacia do Camaquã - Vendiano Superior/Ordoviciano Inferior do RS. In: SIMP. SUL-BRAS. DE GEOL., 6. Porto Alegre (RS), 1995. Bol. Res. Expandidos... Porto Alegre (RS), SBG: 39-50.

PAIM, P.S.G.; LEIPNITZ, I.I.; ROSA, A.L.Z. da; ROSA, A.A.S. da. 1997. Preliminary report on the occurrence of Chancelloria sp. in the Itajai Basin, southern Brazil. Rev. Bras. Geociênc., 27(3): 303-308.

PAIVA, I.P.; BATOLLA Jr., F.; CARVALHO, M.A.S.; COLANERI, S.; AGUIAR NETO, A. 1977. Projeto Leste do Paraná, Folha Apiaí. Rel. Final Conv. DNPM-BADEP. IGUFP, vol.1, São Paulo (SP). 228p.

PETRI, S. \& SUGUIO, K. 1969. Sobre os metassedimentos do Grupo Açungui no extremo sul do Estado de São Paulo. Conv. USP-DAEE, São Paulo (SP). 98p.

PETTIJOHN, P.J.; POTTER, P.E.; SIEVER, R. 1987. Sand and Sandstone, 2nd ed. Springer-Verlag, New York. 553p.

PICANÇO, J.L. \& TASSINARI, C.C.G. 1999. Sr and $\mathrm{S}$ isotopic composition from the Campo Largo auriferous district, Paraná State, southern Brazil. In: SIMPOSIO SUDAMERICANO DE GEOLOGIA ISOTOPICA (SSAGI), II. Córdoba, 1999. Actas... 488-489.

PIEKARZ, G.F. 1980. Geologia e potencial econômico da Seqüência Perau. Rel. Int. MINEROPAR, vol.l, Curitiba (PR). 83p.

PIEKARZ, G.F. 1984. Geologia e resultados preliminares de pesquisa mineral do Núcleo Betara da Formação Perau. In: CONGR. BRAS. DE GEOL., XXXIII. Rio de Janeiro (RJ), 1984. Anais... Rio de Janeiro (RJ), SBG 8: 3682-3696.

PIEKARZ, G.F.; SCHRANK, A.; CHOUDHOURI, A.; FIGUEIREDO, B.; XAVIER, R. 1991. A porphyry-type gold deposit in the Passa Três Granite, South Brazil. In: LADEIRA, E.A., ed. 1991. Brazil Gold '91: The Economics, Geology, Geochemistry and Genesis of Gold Deposits (Proceedings of the Symposium Brazil 
Gold '91, Belo Horizonte-MG', May 13-17/1991). A.A. Balkema, Rotterdam/Brookfield: 541-546.

PIERI, P.; SABATO, L. LOIACONO, F.; MARINO, M. 1994. Il bacino di piggyback di Sant' Arcangelo: evoluzione tettonico-sedimentaria. Bol. Soc. Geol. It., 113: 465481.

PICKERING, K.; STOW, D.; WATSON, M.; HISCOTT, R. 1986. Deep water facies, processes and models: a review and classification scheme for modern and ancient sediments. Earth Sci. Reviews, 23:75-174.

PIRAJNO, F. 1992. Hydrothermal mineral deposits, principles and fundamental concepts for the exploration geologist. Springer-Verlag, New York. 709p.

PLINT, A.G., ed. 1995. Sedimentary facies analysis. Intern. Assoc. of Sedimentologists Spec. Publ., 22. 384p.

POLIDORO, G.F.B. \& GONÇALVES, M.R. 1984. Relatório da folha geológica parcial de: Bateias, Cerne, Ouro Fino e Campo Magro. Rel. Grad. UFPR, Curitiba (PR). 64p.

PONTES, J.B. 1981. Investigações e potencialidades econômicas da Formação Água Clara (PR). Rel. Int. MINEROPAR, Curitiba (PR). 34p.

PONTES, J.B. 1982. Geologia e potencialidade econômica da Formação Água Clara (PR). In: CONGR. BRAS. DE GEOL., XXXII. Salvador (BA), 1982. Anais... Salvador (BA), SBG 3: 1002-1016.

POPP, J.H. 1972. Contribuição à estratigrafia e sedimentologia da Formação Camarinha (Pré-Devoniano do Estado do Paraná). Dissert. Mestrado UFRGS, Porto Alegre (RS). $71 \mathrm{p}$.

POPP, J.H.; ANGULO, R.J.; BIGARELLA, J.J. 1979. Geologia. In: BIGARELLA, J.J. ed. 1979. Recursos Minerais, Folha de Ouro Fino. Sec. Estado de Planejamento/ADEA/UFPR, Curitiba (PR): 22-26.

POSTMA, G. 1990. Depositional architecture and facies of river and fan deltas: a synthesis. In: COLELLA, A. \& PRIOR, D.B., eds. 1990. Coarse-grained deltas. Intern. Assoc. of Sedimentologists Spec. Publ., 10: 13-27.

POSTMA, G. \& CRUICKSHNK, C. 1988. Sedimentology of a late Weichselian to Holocene terraced fan delta. Varangerfjord, northern Norway. In: NEMEC, W. \& STEEL, R.J., eds. 1988. Fan deltas: sedimentology and tectonic settings. Blackie and Son, Glasgow: 143-152.

POTTER, P.E. \& PETTIJOHN, F.J. 1977. Paleocurrents and basin analysis, 2nd ed. Springer-Verlag, New York. 425p. 
PRAZERES FILHO, H.P.; BASEI, M.A.S.; REIS NETO, J.M. dos; SIGA Jr., O.; SATO, $\mathrm{K}$. em prep. U-Pb geochronology and $\mathrm{Sm}-\mathrm{Nd}$ and $\mathrm{Pb}-\mathrm{Pb}$ isotopic studies of Cunhaporanga and Três Córregos granitoid complexes - Paraná State, southern Brazil. Encaminhado ao INTERN. GEOL. CONGRESS, 31st. Rio de Janeiro (RJ), em organização.

PRIOR, D.B. \& BORNHOLD, B.D. 1988. Submarine morphology and processes of fjord fan deltas and related high-gradient systems: modern examples from British Columbia. In: NEMEC, W. \& STEEL, R.J., eds. 1988. Fan deltas: sedimentology and tectonic settings. Blackie and Son, Glasgow: 125-143.

PRIOR, D.B. \& BORNHOLD, B.D. 1990. The underwater development of Holocene fan deltas. In: COLELLA, A. \& PRIOR, D.B., eds. 1990. Coarse-grained deltas. Intern. Assoc. of Sedimentologists Spec. Publ., 10: 75-90.

RACHOCKI, A. 1981. Alluvial Fans: an attempt to an empirical approach. John Wiley \& Sons, New York. 161p.

RACHOCKI, A.H. \& CHURCH, W., eds. 1990. Alluvial Fans: a field approach. John Wiley \& Sons, Chichester. 391p.

RAGAN, D.M. 1980. Geología estructural: introducción a las tecnicas geometricas. $E d$. Omega S.A., Barcelona. 207p.

RAMSAY, J.G. \& HUBER, M.I. 1993. The techniques of modern structural geology. Vol.1: Strain analysis. Harcourt Brace \& Co., Publ. (Academic Press), Oxford.
307p.

READIN, H.G. 1980. Characteristics and recognition of strike-slip fault systems. In: BALLANCE, P.F. \& READING, H.G., eds. 1980. Sedimentation in oblique-slip mobile zones. Intern. Assoc. of Sedimentologists Spec. Publ., 4: 7-26.

READING, H.G., ed. 1996. Sedimentary Environments: processes, facies and stratigraphy, 3rd ed. Blackwell Sci. Ltd., Cambridge. $688 \mathrm{p}$.

READING, H.G. \& COLLINSON, J.D. 1996. Clastic coasts. In: READING, H.G., ed. 1996. Sedimentary Environments: processes, facies and stratigraphy, 3rd ed. Blackwell Sci. Ltd., Cambridge: 154-231.

REINECK, H.E. \& SINGH, I.B. 1975. Depositional Sedimentary Environments. SpringerVerlag, Berlin-Heidelberg. 439p.

REIS NETO, J.M. dos. 1994. Faixa Itaiacoca: Registro de uma colisão entre dois blocos continentais no Neoproterozóico. Tese de Doutoramento IG-USP, São Paulo (SP).
$253 \mathrm{p}$.

RIBEIRO, M. 1970. Geologia da Folha de Bom Jardim, Rio Grande do Sul, Brasil. Bol. 
Div. Geol. Min. DNPM, 247:1-142

RIBEIRO, M. \& FANTINEL, L.M. 1978. Associações petrotectônicas do Escudo SulRiograndense: I. Tabulação e distribuição das associações petrotectônicas do Escudo do Rio Grande do Sul. Inheringia, Série Geologia, 5:19-54.

RIBEIRO, M.; BOCCHI, P.R.; FIGUEIREDO FILHO, P.M.; TESSARI, R.I. 1966. Geologia da Quadrícula de Caçapava do Sul, Rio Grande do Sul. Bol. Div. Fomento da Prod. Min. DNPM, 127: 1-232.

RICCI-LUCCHI, F. 1985. Influence of transport processes and basin geometry on sand composition. In: ZUFFA, G.G., ed. 1985. Provenance of arenites. D. Reidel Publishing Co.: 19m45.

RICCI-LUCCHI, F. 1986. The oligocene to recent foreland basins of the northern Apennines. In: ALLEN, P.A. \& HOMEWOOD, P. 1986. Foreland basins. Intern. Assoc. of Sedimentologists Spec. Publ., 8: 195-139.

RICCI-LUCCHI, F. 1996. Sedimentografia: atlante fotografico delle strutture dei sedimenti (seconda edizione). Zanichelli, Bologna. 249p.

RICCOMINI, C. 1993. Origem, evolução e inversão da bacia do Pico de Itapeva, Neoproterozóico-Cambriano, São Paulo, Brasil. In: SIMP. INTERN. DEL NEOPROTEROZOICO-CAMBRICO DE LA CUENCA DEL PLATA, 1. La Paloma-Minas, 1993. Resumenes Extensos... Montevideo, DINAMIGE-Fac. Agron., Tomo 1 : res. 16.

RIGBY, J.K. \& HAMBLIN, W.K., eds. 1972. Recognition of ancient sedimentary environments. Soc. of Econ. Paleontologists and Mineralogists Spec. Publ., 16. 340 p.

ROBERTSON, J.F. 1966. Revision of stratigraphy and nomenclature of rock units in Caçapava Lavras region. Notas e Estudos IG-UFRGS, vol.1(2), Porto Alegre (RS): 41-54.

ROSTIROLLA, S.P. 1991. Tectônica e sedimentação da Bacia de Itajaí-SC. Dissert. Mestrado UFOP, Ouro Preto (MG). 132p.

ROWLAND, S.M. \& DUEBENDORFER, E.M. 1994. Structural Analysis and Synthesis: a laboratory course in Structural Geology, 2nd ed. Blackwell Sci. Publ., Boston. 279p.

SALAMUNI, E. 1991. Análise Estrutural do Núcleo Betara, Rio Branco do Sul - PR. Dissert. Mestrado IGCE-UNESP, Rio Claro (SP). 147p.

SANTOS, P.S. 1975. Tecnologia de argilas, aplicada às argilas brasileiras. Ed. Edgard Blücher (USP), São Paulo (SP). 340p. 
SANTOS, E. \& FÁVARO, L. 1997. Relatório do mapa geológico da região de Terra Boa município de Campo Largo - PR. Escala 1:10.000. Rel. Grad. UFPR, Curitiba (PR). 76p.

SANTOS, E.L.; BECKEL, J.; MACEDO, P.M.; GONZALES FILHO, F.; CHABAM, M. 1978. Divisão litoestratigráfica do Eo-Cambriano - Pré-Cambriano Superior do Escudo Sul-Riograndense. In: CONGR. BRAS. DE GEOL., XXX. Recife (PE), 1978. Anais... Recife (PE), SBG 2: 670-684.

SAYEG, H.S.; FAMBRINI, G.L.; MACHADO, R.; FRAGOSO CESAR, A.R.S. 1992a. Evolução brasiliana da bacia transcorrente do Arroio Boici, RS. In: WORKSHOP SOBRE AS BACIAS MOLÁSSICAS BRASILIANAS, I. São Leopoldo (RS), 1992. Bol. Res. Expandidos... São Leopoldo (RS), SBG/UNISINOS: 129-132.

SAYEG, H.S.; FRAGOSO CÉSAR, A.R.S.; MACHADO, R.; FAMBRINI, G.L. 1992b. A bacia transcorrente brasiliana do Vale do Arroio Boici no contexto da Antefossa Arroio dos Nobres, RS. Bol. IG-USP, 12: 103-104.

SCHOBBENHAUS, C.; CAMPOS, D.A.; DERZE, G.R.; ASMUS, H.E. 1981. Mapa Geológico do Brasil e da área oceânica adjacente incluindo depósitos minerais. DNPM. Esc. 1:2.500.000.

SCHÖLL, W.U. 1981. Geologia do Grupo Açungui na região a nordeste de Rio Branco do Sul, PR. In: SIMP. REG. DE GEOL., 3. Curitiba (PR), 1981. Atas... Curitiba (PR), SBG: $170-184$.

SCHÖLL, W.U.; SILVA, A.C.G.A.; MONASTIER, M.S. 1982. A Formação Setuva no Pré-Cambriano do Estado no Paraná. In: CONGR. BRAS. DE GEOL., XXXII. Salvador (BA), 1982. Anais... Salvador (BA), SBG 1: 55-63.

SCHOLLE, P.A. 1979. A collor illustrated guide to constituents, textures, cements and porosities of sandstones and associated rocks. AAPG Memoir, 28. $201 \mathrm{p}$.

SCHOLLE, P.A. \& SPEARING, D., eds. 1982. Sandstone depositional environments. AAPG Memoir, 31.410p.

SELLEY, R.C. 1982. Introduction to Sedimentology, 2nd ed. Academic Press, London. $417 \mathrm{p}$.

SIGA Jr., O. 1995. Domínios Tectônicos do Sudeste do Paraná e Nordeste de Santa Catarina: Geocronologia e Evolução Crustal. Tese de Doutoramento IG-USP, São Paulo (SP). 212p.

SIGA Jr., O.; BASEI, M.A.S.; REIS NETO, J.M. dos; MACHIAVELLI, A.; HARARA, O.M. 1995. O Complexo Atuba: um cinturão paleoproterozóico intensamente retrabalhado no Neoproterozóico. Bol. $I G-U S P, 26: 69-98$. 
SIGA Jr., O.; BASEI, M.A.S.; SATO, K.; CITRONI, S.B.; REIS NETO, J.M. dos; WEBER, W.; LIMA, P.S. de. 1999. Postmorogenic magmatism and sedimentation in neoproterozoic extensional regimes in the brazilian southern region. In: SIMPOSIO SUDAMERICANO DE GEOLOGIA ISOTOPICA (SSAGI), II. Córdoba, 1999. Actas... 367-370.

SILVA, A.J.C.L.P. 1994. O Supergrupo Espinhaço na Chapada Diamantina centro-oriental, Bahia: sedimentologia, estratigrafia e tectônica. Tese de Doutoramento IG-USP, São Paulo (SP). 126p.

SILVA FILHO, W.F. 1997. A Formação Guaritas na porção centro-sudeste da Bacia do Camaquã-RS. Dissert. Mestrado IG-USP, São Paulo (SP). 120p.

SOARES, P.C. 1987. Seqüências tecto-sedimentares e tectônica deformadora no centrooeste do Escudo Paranaense. In: SIMP. SUL-BRAS. DE GEOL., III. Curitiba (PR), 1987. Anais... Curitiba (PR), SBG 2: 743-771.

SOARES, P.C. 1988. Tectônica colisional em torno do Bloco Paraná, Brasil. In: CONG. LAT.-AMER. DE GEOL., VII. Belém (PA), 1988. Anais... Belém (PA), SBG 1: 6379.

SOARES, P.C. \& FIORI, A.P. 1976. Lógica e sistemática na interpretação de fotografias aéreas em geologia. Notícia Geomorfológica, 16 (32): 71-104.

SOARES, P.C. \& GÓIS, J.R. 1987. Geologia do Granito Passa Três (Paraná) e suas mineralizações auriferas. In: SIMP. SUL-BRAS. DE GEOL., III. Curitiba (PR), 1987. Anais... Curitiba (PR), SBG 2: 497-514.

SYLVESTER, A.G. 1988. Strike-slip fauits. Geol. Soc. of America Bull., 100: 1666-1703.

TEIXEIRA, A.L. 1996. Ambientes geradores dos sedimentos da Bacia Eleutério. Dissert. Mestrado IG-USP, São Paulo (SP). 122p.

TEIXEIRA, A.L. \& PETRI, S. 1993. Tectônica e sedimentação da Bacia Eleutério (Eopaleozóico?), sudeste do Brasil. In: SIMP. INTERN. DEL NEOPROTEROZOICO-CAMBRICO DE LA CUENCA DEL PLATA, 1. La Paloma-Minas, 1993. Resumenes Extensos... Montevideo, DINAMIGE-Fac. Agron., Tomo 1: res. 17.

TESSARI, R.I. \& PICADA, R.S. 1966. Geologia da Quadrícula Encruzilhada do Sul, Rio Grande do Sul, Brasil. Bol. Div. Fomento da Prod. Min. DNPM, 124: 1-147.

THOMAZ FILHO, A. 1976. Potencialidades do método Rb-Sr para datação de rochas sedimentares argilosas. Tese de Doutoramento IG-USP, São Paulo (SP). 128p.

THOMPSON, A.J.B.; THOMPSON, J.F.H; DUNNE, K.P.E. 1996. Atlas of alteration: a 
field and petrographic guide to hydrothermal alteration minerals. Geol. Assoc. of Canada, Mineral Deposits Division (Alpine Press Lim.), Vancouver. 119p.

TREIN, E. \& FUCK, R.A. 1967. O Grupo Castro. Bol. Paran. Geociênc., 23-25: 257-305.

TSEYSLER, V.M. 1973. The relationship between molasse and orogenic structures. Geotectonics, 7(1): 1-7.

TUCKER, M. 1989. The field description of sedimentary rocks. Geol. Soc. of London, Handbook Series. 112p.

WALKER, R.G. 1992. Turbidites and submarine fans. In: WALKER, R.G. \& JAMES, N.P., eds. 1992. Facies Models: response to sea level change. Geol. Assoc. of Canada, Ontario: 239-263.

WAIKKER, R.G. \& JAMES, N.P., eds. 1992. Facies Models: response to sea level change. Geol. Assoc. of Canada, Ontario. 454p.

WESCOTT, W.A. \& ETHRIDGE, F.G. 1990. Fan Deltas: alluvial fans in coastal settings. In: RACHOCKI, A.H. \& CHURCH, W., eds. 1990. Alluvial Fans: a field approach. John Wiley \& Sons, Chichester: 3-24.

WILCOX, R.E.; HARDING, T.P.; SEELY, D.R. 1973. Basic wrench tectonics. AAPG Bull., 57(1): 74-96.

WILLIAMSON, J.H. 1968. Least-squares fitting of a straight line. Can. Jour. of Physics, 46: $1845-1847$.

WOODWORTH, V.B. 1916. Geological Expedition to Brazil and Chile. Bull. Mus. Com. Zool., 56(1): 14.

WOSNIAK, A.P.G. \& FEOLA, J.L. 1997. Relatório do mapa geológico da região de Invernada - Campo Largo - PR. Rel. Grad. UFPR, Curitiba (PR). 109p.

ZALÁN, P.V.; WOLFF, S.; CONCEIÇÃO, J.C.J.; ASTOLFI, M.A.M.; VIEIRA, I.S.; APPI, V.T.; ZANOTTO, O.A. 1987. Tectônica e sedimentação da Bacia do Paraná. In: SIMP. SUL-BRAS. DE GEOL., III. Curitiba (PR), 1987. Anais... Curitiba (PR), SBG 1: 441-476.

ZUFFA, G.G., ed. 1985. Provenance of arenites. D. Reidel Publishing Co., Dordrecht. 408p. 